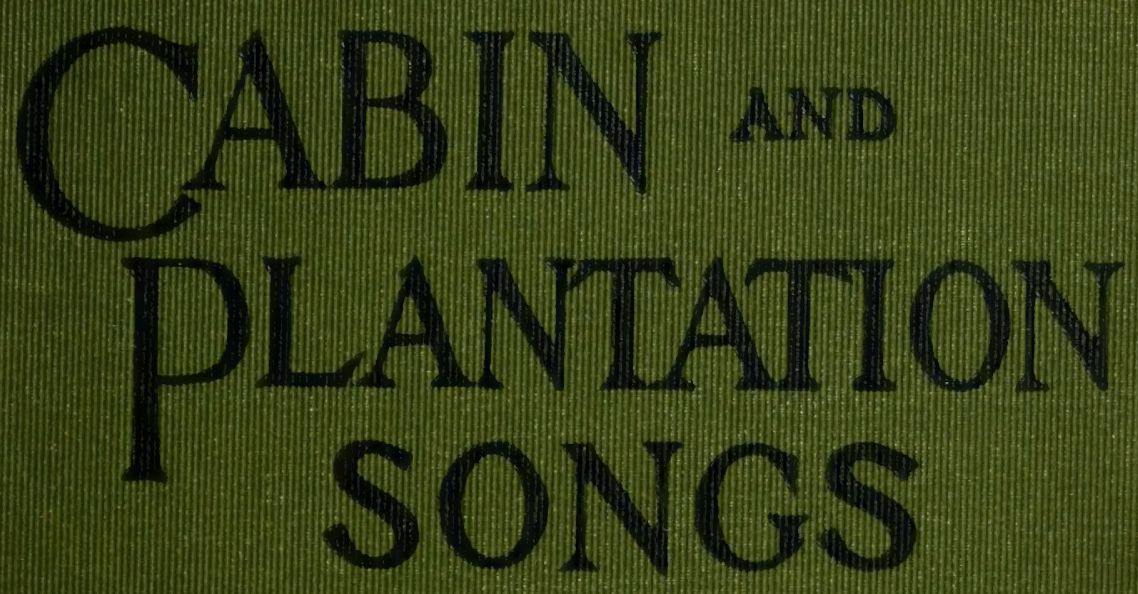

$$
\text { AS SUNG BY THE }
$$

\title{
HaMpton Students
}

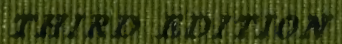

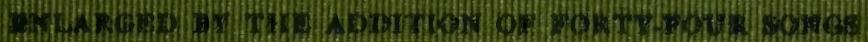








\section{CABIN AND PLANTATION}

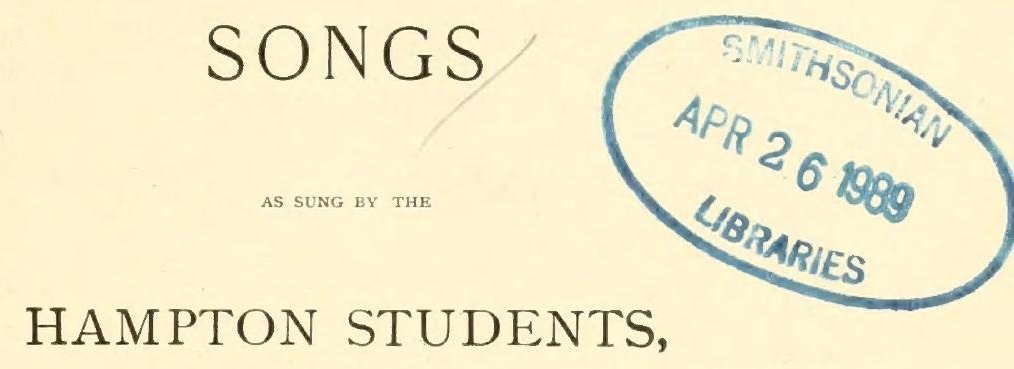

ARRANGED BY

THOMAS P. FENNER, FREDERIC G. RATHBUN, AND

Miss BESSIE CLEAVELAND,

MUSICAL INSTRUCTORS IN THE HAMPTON NORMAL AND AGRICULTURAL INSTITUTE OF VIRGINIA.

THIRD EDITION,

ENLARGED BY THE ALDITION OF FORTY-FOUR SONGS.

TO WHICH ARE ADDED A FEW INDIAN SONGS, GATHERED AT HAMPTON INSTITUTE, THE NEgROES' BATTLE HYMn, AND THE GRACE AS SUNG AT HAMPTON.

G. P. PUTNAM'S SONS NEW YORK AND LONDON Tbe $\mathbb{T k n i c k e r b o c k e r}$ Ipregs 1901 
COPYRIGHT, 1890 BY

F. C. BRIGGS

Enlarged Edition

COPYRIGHT, I9OO

BY

F. C. BRIGGS

Tbe Thíckerbocker Presg, "Aew Work 


\section{PREFACE TO MUSIC.}

THE slave music of the South presents a field for research and study very extensive and rich, and one which has been scarcely more than entered upon.

There are evidently, I think, two legitimate methods of treating this music: either to render it in its absolute, rude simplicity, or to develop it without destroying its original characteristics; the only proper field for such development being in the harmony.

Practical experience shows the necessity, in some cases, of making compensation for its loss in being transplanted. Half its effectiveness, in its home, depends upon accompaniments which can be carried away only in memory. The inspiration of numbers; the overpowering chorus, covering defects; the swaying of the body; the rhythmical stamping of the feet; and all the wild enthusiasm of the negro camp-meeting - these evidently can not be transported to the boards of a public performance. To secure variety and do justice to the music, I have, therefore, treated it by both methods. The most characteristic of the songs are left entirely or nearly untouched. On the other hand, the improvement which a careful bringing out of the various parts has effected in such pieces as "Some $o$ ' dese Mornin's," "Bright Sparkles in de Churchyard," "Dust an'Ashes," and "The Church ob God," which seemed especially susceptible to such development, suggests possibilities of making more than has ever yet been made out of this slave music.

Another obstacle to its rendering is the fact that tones are fre- 
quently employed which we have no musical characters to represent. Such, for example, is that which I have indicated as nearly as possible by the flat seventh, in "Great Camp-meetin'," "Hard Trials," and others. These tones are variable in pitch, ranging through an entire interval on different occasions, according to the inspiration of the singer. They are rarely discordant, and often add a charm to the performance. It is of course impossible to explain them in words, and to those who wish to sing them, the best advice is that most useful in learning to pronounce a foreign language: Study all the rules you please; then-go listen to a native.

One reason for publishing this slave music is, that it is rapidly passing away. It may be that this people which has developed such a wonderful musical sense in its degradation will, in its maturity, produce a composer who could bring a music of the future out of this music of the past. At present, however, the freedmen have an unfortunate inclination to despise it, as a vestige of slavery; those who learned it in the old time, when it was the natural outpouring of their sorrows and longings, are dying off, and if efforts are not made for its preservation, the country will soon have lost this wonderful music of bondage.

The melodies in this book, with few exceptions, are published here for the first time, and these exceptions are themselves original in arrangement and effect. The words of the slave hymns are often common property through the South, sung to different tunes in different sections of the country.

\section{THOMAS P. FENNER.}

HАMpton, VA., January $1,1874$. 


\section{INTRODUCTION.}

TN publishing this new and enlarged edition of the Hampton Songs, little explanation is needed, for it is done in response to a demand. Ever since the publication of the first edition, in $18 \% 4$, when the band of Hampton Student Singers were helping to raise the walls of Virginia Hall by their concerts in the North, there have been frequent requests for their music. Mean while, though the old favorites have not been neglected, many more melodies, striking and beautiful, have been brought in by students from various parts of the South. The field seems almost inexhaustible. Their origin no one exactly knows. An old "Aunty," questioned on the subject, declared that "When Mass'r Jesus He walk de earth, when He feel tired He sit a-restin' on Jacob's well and make up dese yer spirituals for His people." A half-familiar strain, recalling some old ballad or psalm-tune, now and then suggests a possible solution for some of them ; and, as Lowell said of Chaucer, "If one can transmute lead into gold, why ask where he got his lead?" So strikingly original, as well as of such quaint, pathetic, even artistic beauty, are most of them, that they justify Edward Everett Hale's assertion, that they are "the only American music."

A consideration of the slave music of the South, from the musician's standpoint, was made by Mr. Thomas P. Fenner, who trained the original band of Hampton Student Singers, and arranged the songs in the first edition of this book, his preface to which is subjoined. The disposition which he noticed in the freedmen to be 
ashamed of the songs of slave times still exists. Some of the old ring is lost with the experience that called it forth. Yet the people are still natural musicians, and it is easy to arouse in the more advanced an intelligent interest in the characteristic music which excites so much sympathy and respect for their race, is so identified with their past history and their present fortunes.

\section{NOTE TO THIRD EDITION.}

In 1891 a second edition was printed, and to this was added several new songs, including a few from Indian and other nationalities represented at Hampton, arranged by Mr. F. G. Rathbun, at that time musical director at Hampton, and also a few from the Tuskegee collection arranged by Mr. R. H. Hamilton, a graduate of Hampton and one of the original band of Hampton Singers.

To these are now added over forty new ones, collected and arranged by Miss Bessie Cleaveland, musical instructor at Hampton since 1892 .

The hymn called by General Armstrong the Negroes' Battle Hymn, sung by his colored soldiers during the war and since then at Hampton, is added to the collection; also, by special request, the grace sung at meal-time by the students of the school.

HAMPTON, January, 1901. 


\section{CABIN AND PLANTATION SONGS.}

\section{(O), Den my little Soul's gwille to Shime.}

"THIs was sung by a boy who was sold down South by his master; and when he parted from his mother, these were the words he saug." - J. H. BAILEY.

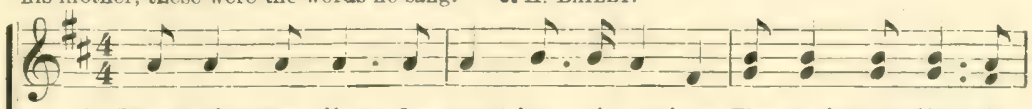

1. I'm gwine to jine de great 'so - ci - a-tion, I'w gwine to jine de
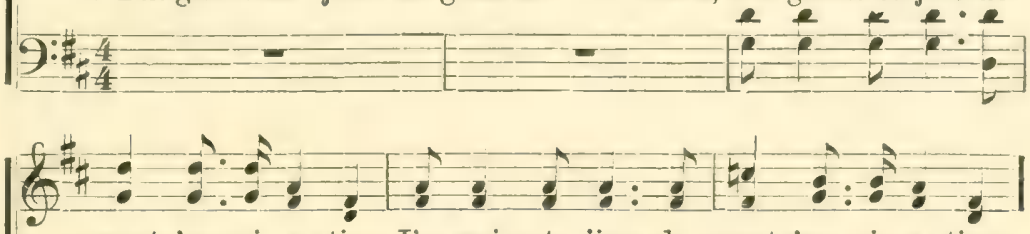

great 'so - ci - a-tion, I'm gwine to jine de great 'so-ci-a-tion;

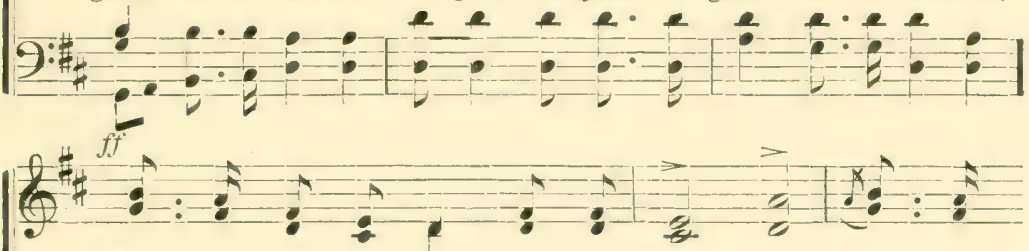

Den my lit - tle soul's gwine to sinine, shine, Den my
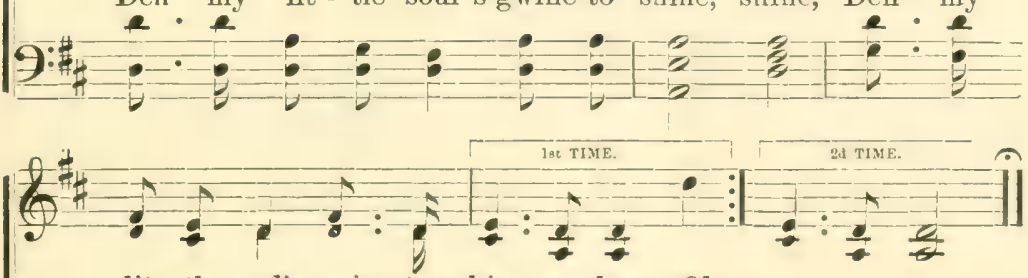

lit - tle soul's gwine to shine a - long. Oh,

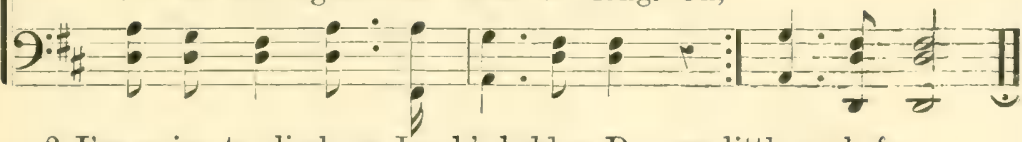

2 I'm gwine to climb up Jacob's ladder, Den my little soul, de.

3 I'm gwine to climb up higher and higher, Den my little soul, \&c.

4 I'm gwine to sit down at the welcome table, Den my little soul, \&c.

5 I'm gwine to feast off milk and honey, Den my little sonl, \&c.

6 I'm gwine to tell God how-a you sarved me, Den my little soul, \&c.

7 I'm gwine to jine de big baptizin', Den my little soul, \&c. 


\section{国eter, go liing rem Bells.}

“A secret prayer-meetiug song, sung by Thomas Vess, a blacksmith and a slave. He especial. 1y 1y sang it when ane it seemed like a prayer-meeting did not go on well songs, for in the neighborbood where he lived, it seemed like a pray what happiness he got from them."

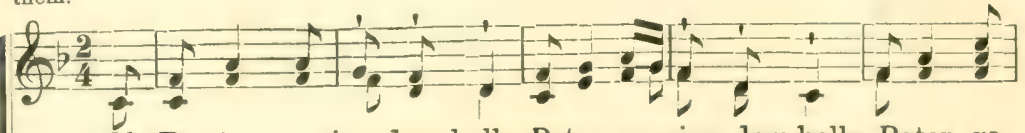

1. Oh Pe - ter, go ring dem bells, Peter, go ring dem bells, Peter, go
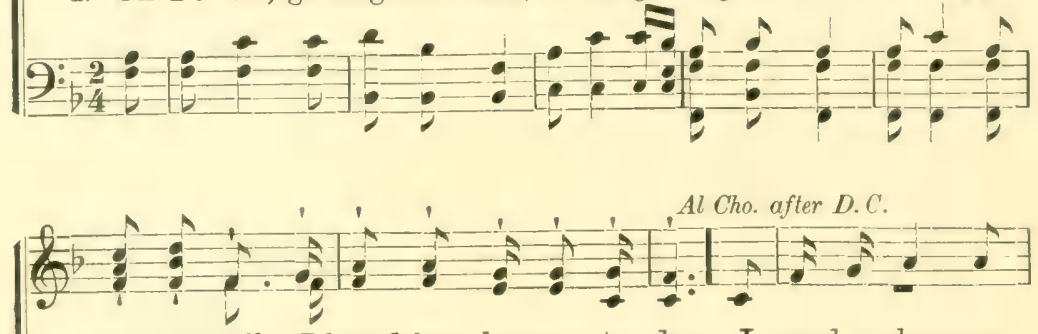

ring dem bells, I heard from heav-en to-day. I wonder where my
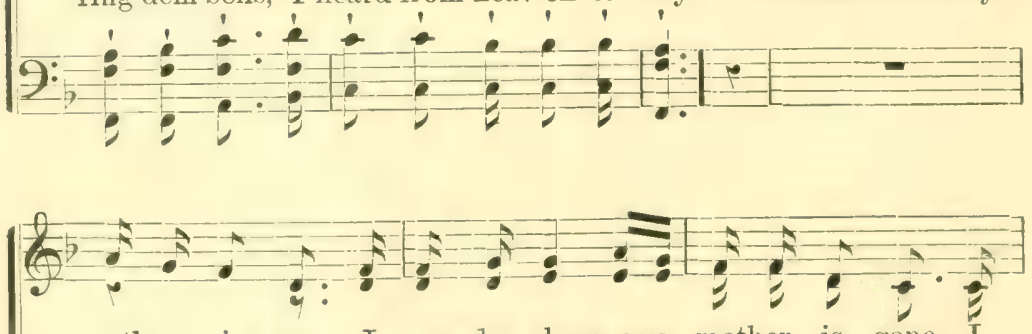

mother is gone, I won-der where my mother is gone, I

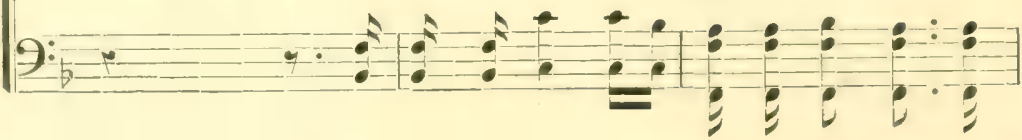

D.C.

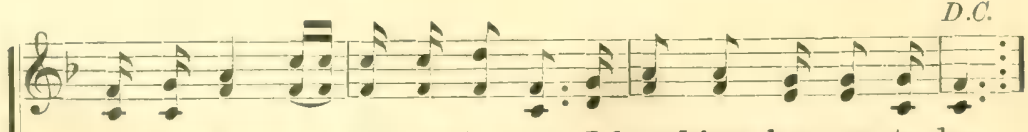

wonder where my moth-er is gone, $\mathbf{I}$ heard from heav-en to-day.

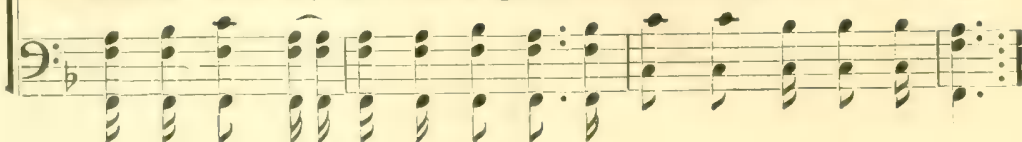


Jetre, go liing Dem Lidls.-Concluded.
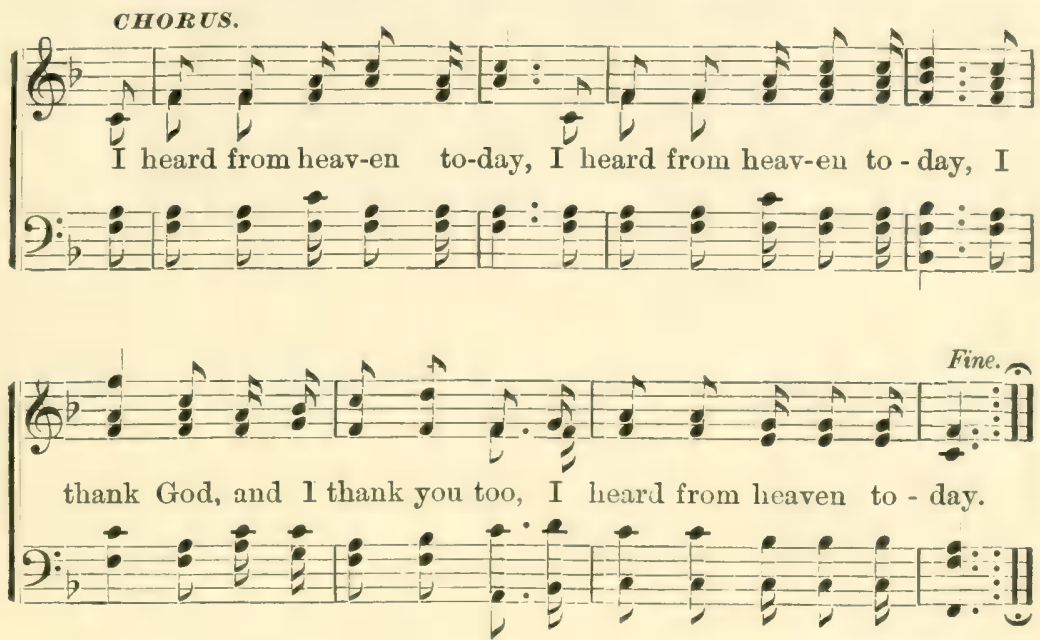

2 I wonder where sister Mary's gone-

I heard from heaven to-day;

I wonder where sister Martha's gone-

I heard from heaven to-day;

It's good news, and I thank God-.

I heard from heaven to-day.

Oh, Peter, go ring dem bells-

I heard from heaven to-day.

Сно.-I heard from heaven, \&c.

3 I wonder where brudder Moses gone-

I heard from heaven to-day;

I wonder where brudder Daniel 's gone-

I heard from heaven to-day;

He's gone where Elijal has gone-

I heard from heaven to-tay;

Oh, Peter, go ring dem bells-

I heard from heaven to-day.

Cво.-I heard from heaven, \&c。 


\section{ftly 32 ori, what a ftlorming.}

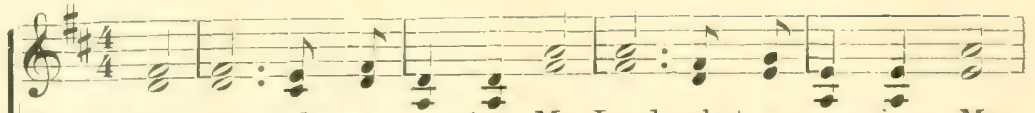

1. My Lord, what a morning, My Lord, what a morn-ing, My
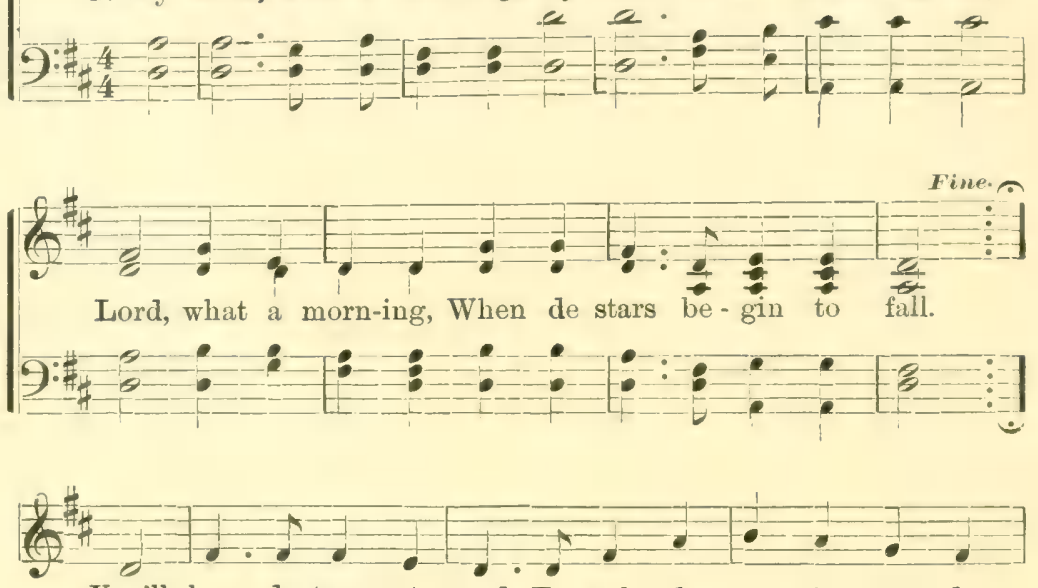

You'll hear de trumpet sound, To wake de na-tions un - der -

You'll hear de sin - ner moan, To wake, \&c.

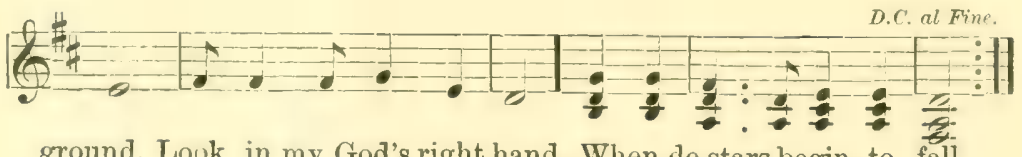

ground, Louk in my God's right band, When de stars begin to fall.

2 You 'll hear de Christians shout, To wake, \&c.

Look in my God's right hand, When de stars, \&c.

You 'll hear de angels sing, To wake, \&c.

Look in my God's right hand, When de stars, \&c.

Сно.-My Lord, what a morning, \&c.

3 You 'll see my Jesus come, To wake, \&c.

Look in my God's right hand, When de stars, \&c.

His chariot wheels roll round, To wake, \&c.

Look in my God's right hand, When de stars, \&c.

Cно.-My Lord, what a morning, \&c. 


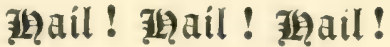

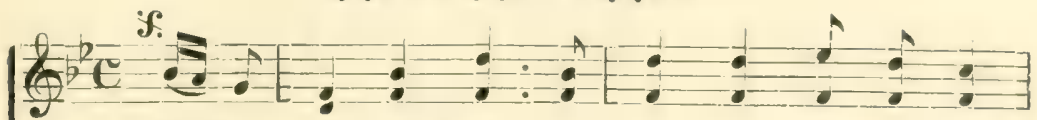

Children, hail! hail! hail! I'm gwine jine saints a-bove;
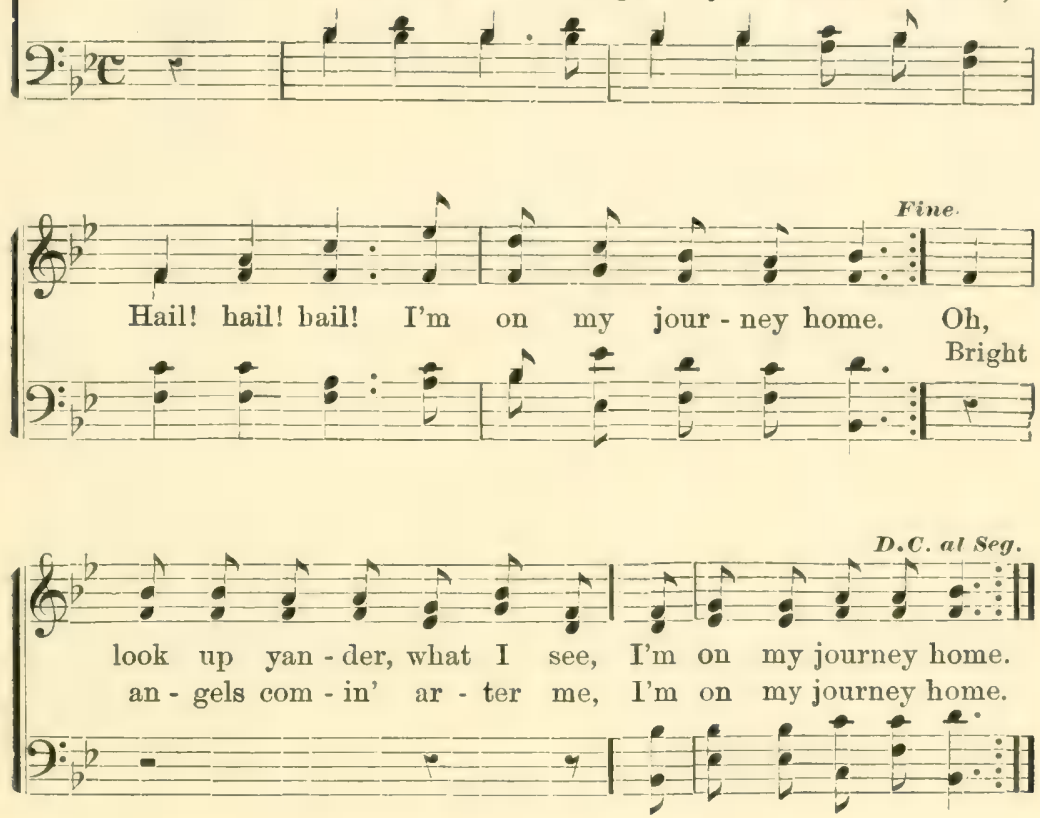

2 If you git dere before $\mathbf{I}$ do, I'm on my journey home-

Look out for me-I'm comin' too;

I'm on my journey home.

Сно.-Children, hail, \&c.

$3 \mathrm{Oh}$, hallelujah to de Lamb!

I'm on my journey home;

King Jesus died for ebry man,

I'm on my journey home.

CHo.-Children, hail, \&c. 


\section{3lobe an' serbe òe 3lorio.}

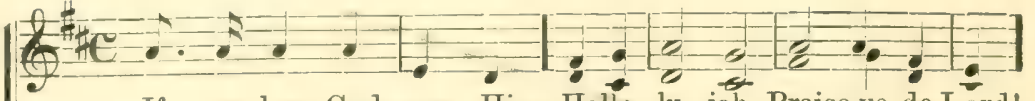

If ye love God, serve Him, Halte - lu - jah, Praise ye de Lơrd! C. Comego to glo - ry with me,
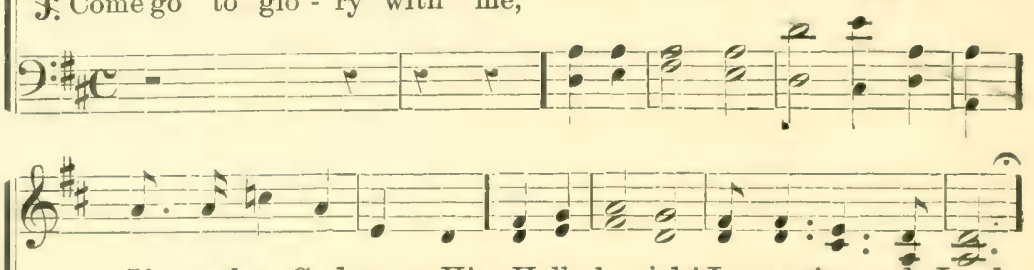

If ye love God, serve Him, Halle-lu - jah! Love an'serve de Lord.

Come, go to glo-ry with me.
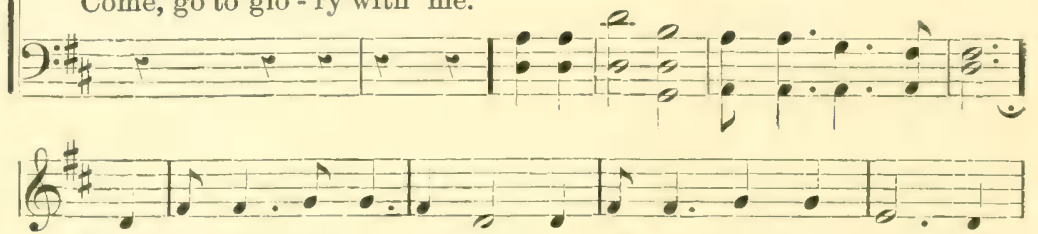

Good mornin', brother trav'ler, Pray tell me where you're bound? I'm

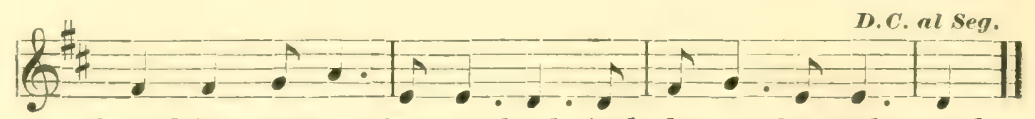

bound for Canaan's hap-py land, And de en-chant-ed ground.

$2 \mathrm{Oh}$, when I was a sinner,

I liked my way so well;

But when I come to find out,

I was on de road to hell.

Сно.-I fleed to Jesus-Hallelujah! \&c.

Oh, Jesus received me, Hallelujah, \&c.

3 De Father, He looked on de Son, and smiled,

De Son, He looked on me;

De Father, redeemed my soul from hell;

An' de Son, $\mathrm{He}$ set me free.

Сно.-I shouted Hallelujah! Hallelujah, \&c.

I praised my Jesus, Hallelujah, \&c.

4 Oh when we all shall get dere,

Upon dat-a heavenly sho',

We'll walk about dem-a golden streets,

An' nebber part no mo'.

Сно.- - No rebukin' in de churches-Hallelujah,

Ebery day be Sunday-Hallelujah, \&c. 


\section{Swing low, swert Chariot.}

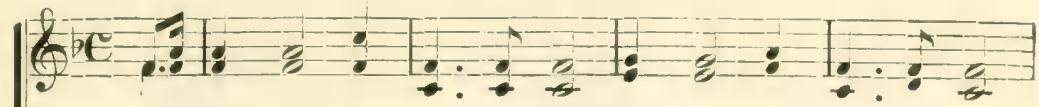

Oh swing low, sweet cha - ri - ot, Swing low, sweet cha - ri - ot,

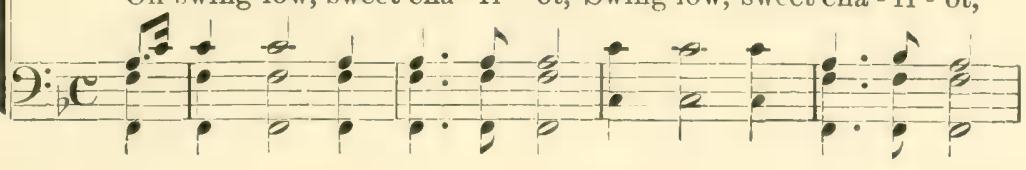

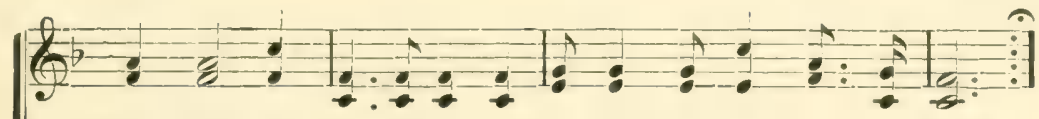

Swing low, sweet cha-ri - ot, I don't want to leave me be-hind.
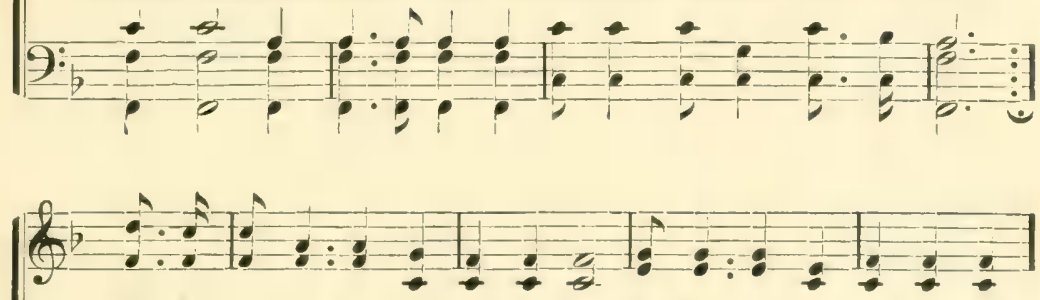

Oh de good ole chariot swing so low, Good ole chariot swing so low,
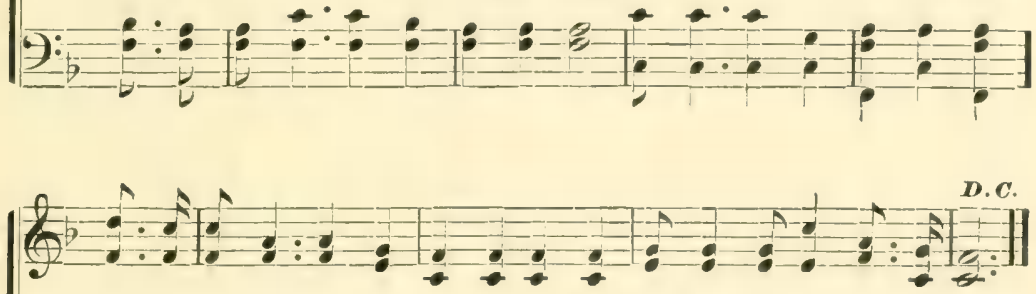

Oh de good ole chariot swing so low, I don't want to leave me behind.

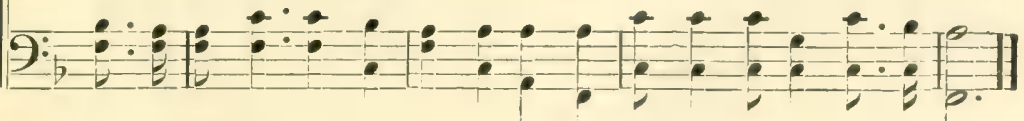

2 Oh de good ole chariot will take us all home, I don't want to leave me behind.

Сно.-Oh swing low, sweet chariot, \&c. 


\section{ftly bretheren, ron't get Jekeary.}

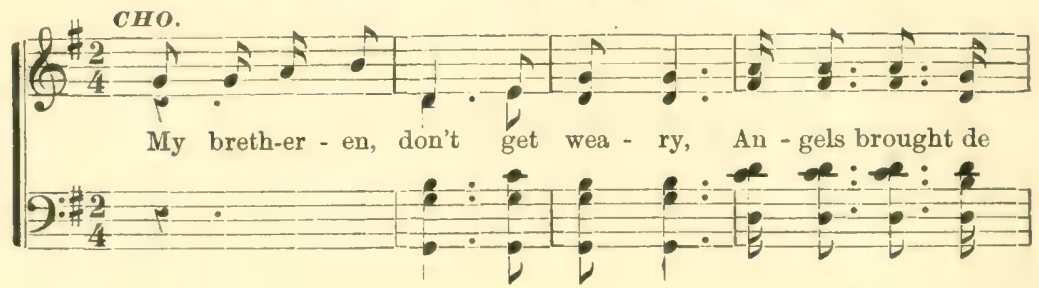

| 1st. $\mid 2 d$.

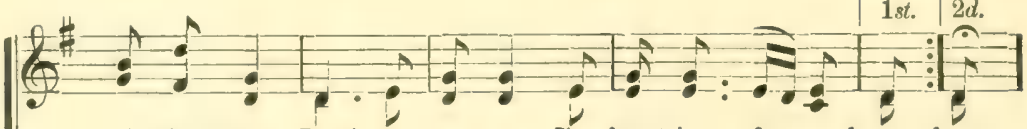

ti-ding down; Don't get wea-ry, I'm hunt-ing for a home. home.
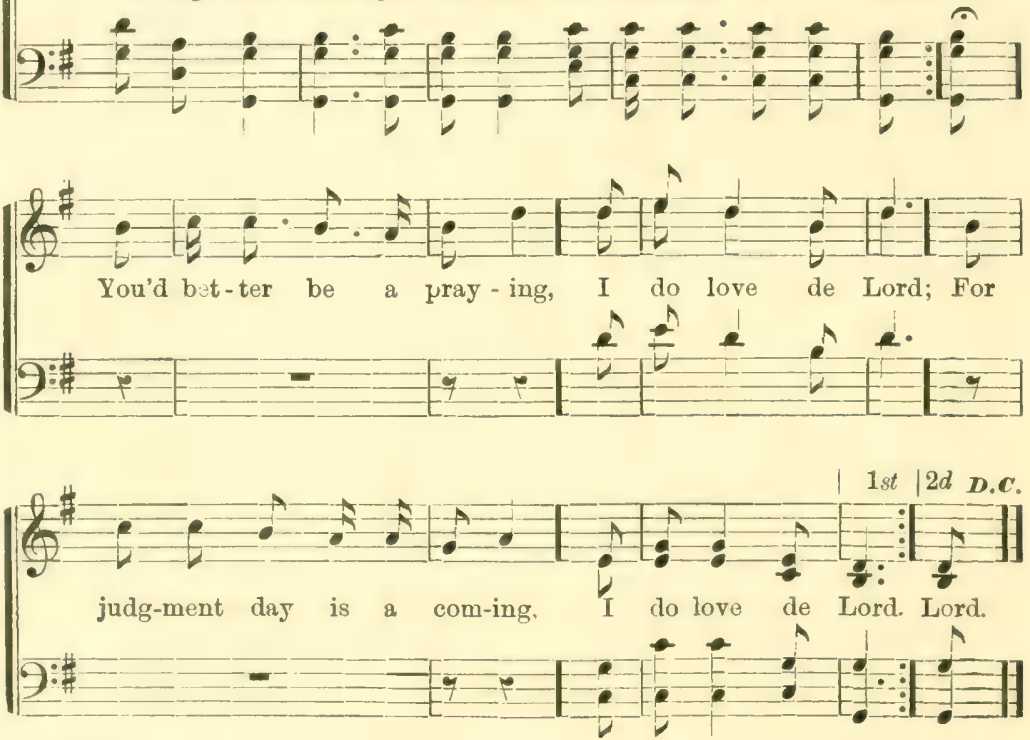

2 Oh whar you runnin', sinner ? I do love de Lord-

De judgment day is a comin'! I do love de Lord.

Сно.- My bretheren, \&c.

3 You'll see de world on fire!

I do love de Lord-

You'll soe de element a meltin',
I do love de Lord. Сно.--My bretheren, \&c.

4 You'll see de moon a bleedin'; I do love de Lord-

You'll see the stars a fallin';

I do love de Lord.

Сно.-My bretheren, \&c. 


\section{Roboon knows de trouble F'ue Sern.}

(This song was a favorite in the Sea Islands. Once when there had been a good deal of ill feeling excited, and trouble was appreheuded, owing to the uncertain action of the Government in regard to the contiscated lands on the Sea Islands, Gen. Howard was called upon to address the colored people earnestly. To prepare them to listen, he asked them to sing. Immediately an old woman on the outskirts of the meeting began "Nobody knows the trouble I've seen," and the whole audience joined in. The General was so affected by the plaintive melody, that he found it difficult to maintain his official dignity.)

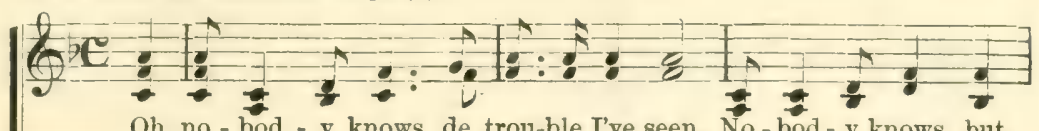

Oh, no - bod - y knows de trou-ble I've seen, No-bod-y knows but
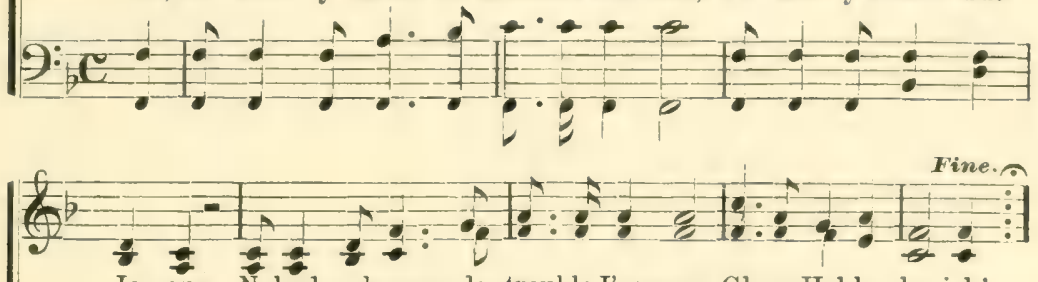

Je-sus, Nobod-y knows de trouble I've seen. Glory Hal-le - lu-jah!
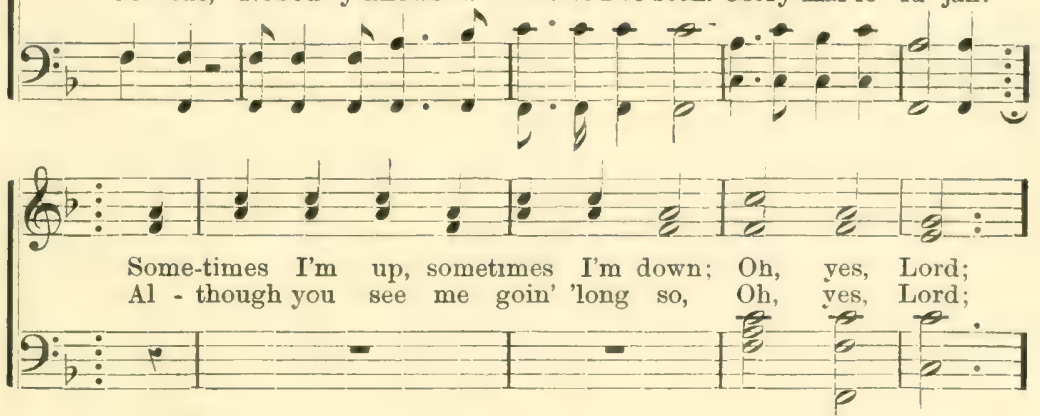

D.C. al Fine.

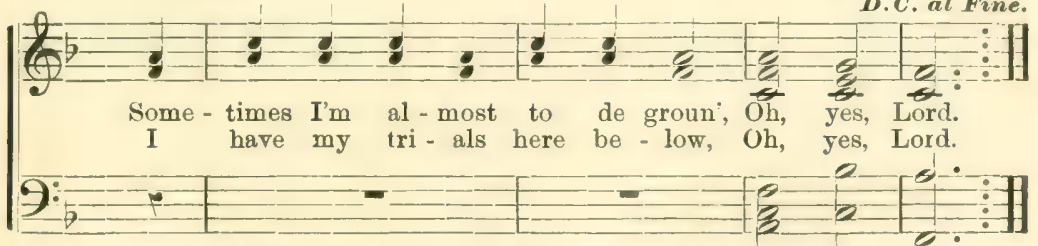

2 One day when I was walkin' along, Oh yes, Lord-

De element opened, an' de Love came down, Oh yes, \&c.

I never shall forget dat day, Oh yes, \&c.

When Jesus washed my sins away, Oh yes, \&c.

Сно.-Oh, nobody knows de trouble I've seen, \&c. 
CHORUS.

\section{View de 3 Lando.}
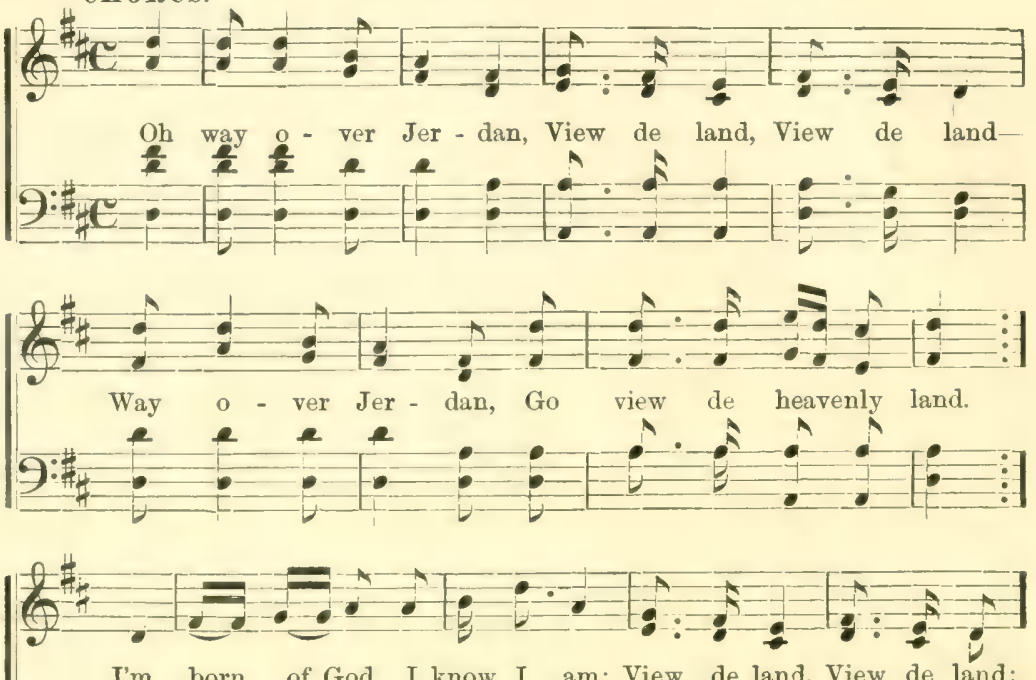

I'm born of God, I know I am: View de land, View de land;

I want to go to heaven when I die; View de land, View de land;
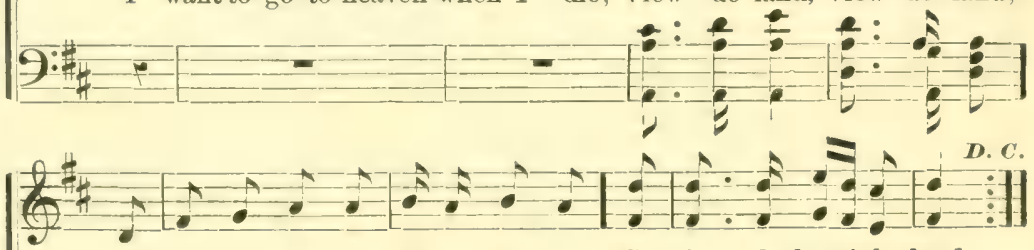

And you de-ny it, if -a you can, Go view de heav'nly land.

To shout sal-va-tion as-a I fly, Go view de heav'nly land.

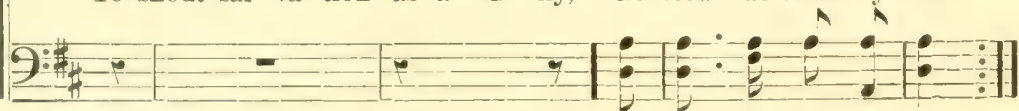

2 What kind o' shoes is dem-a you wear? View de land, \&c.

Dat you can walk upon de air? Go view, dc.

Lem shoes I wear am de gospel shoes; View de land, \&c.

An' you can wear dem ef-a you choose; Go view, \&c.--Cho.

3 Der' is a tree in Paradise; View de land, \&c.

De Christian he call it de tree ob life; Go view, \&c.

I spects to eat de fruit right off o' dat tree; View de land, \&c,

Ef busy old Satan will let-a me be; Go view, \&c.-.Cho.

4 You say yer Jesus set-a you free; View de land, \&c.

Why don't you let-a your neighbor be? Go view, \&c.

You say you're aiming for de skjes: View de land, \&c.

Why don't you stop-a your telling lies; Go view, \&c.-Cho. 
CHORTS.

\section{The 更anbille chariot.}
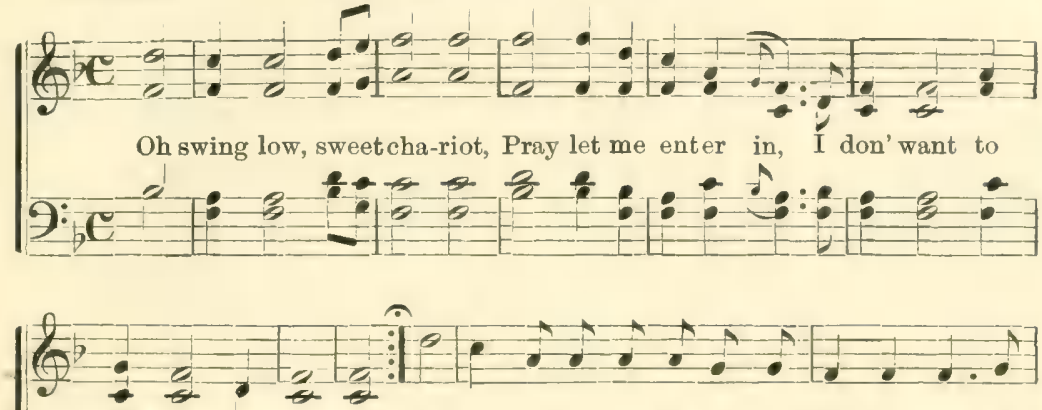

stay here no long-er. I done been to heaven, an' I done been tried, I Oh down to de wa - ter I was led, my

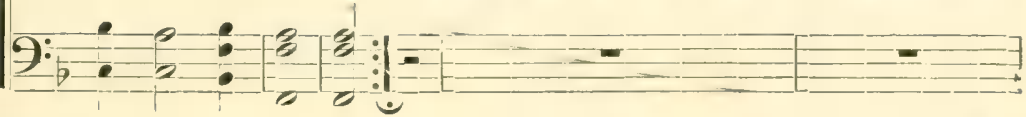

D. C.

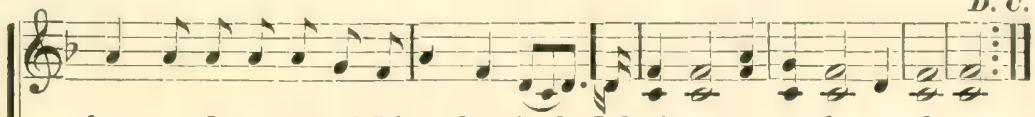

been to de water, an' I been baptized, I don' want to stay here no longer. soul got fed with de heav'nly bread, I don' want to stay here no longer.

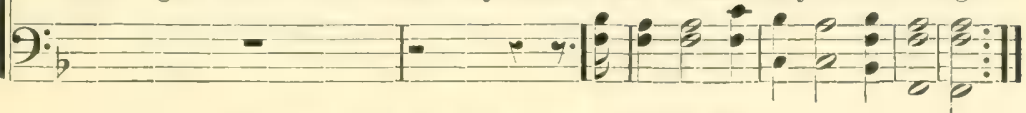

2 I had a little book, an I read it through,

I got my Jesus as well as you;

I don' want to stay here no longer;

Oh I got a mother in de promised land,

I hope my mother will feed dem lambs; I don' want to stay here no longer.

CHo.--Oh swing low, sweet chariot, \&c.

$3 \mathrm{Oh}$, some go to church for to holler an' shout,

Before six months dey're all turned out;

I don' want to stay here no longer.

Oh, some go to church for to laugh an' talk,

But dey knows nothin' bout dat Christian walk;

I don' want to stay here no longer.

Сно._-Oh, swing low, sweet chariot, \&e.

$4 \mathrm{Oh}$ shout, shout, de deb'l is about;

Oh shut your do' an' keep him out;

I don' want to stay here no longer.

For he is so much-a like-a snaky in de grass,

Ef you don' mind he will get you at las',

I don' want to stay here no longer.

Сно.--Oh, swing low, sweet chariot, \&c. 


\section{JEf pe mant to see Jissus.}

"My father sang this lymu, and said he knew a time when a great many slaves were allowed to have a revival for two days, while their masters and their families had one; and a great many professed religion. And one poor, ignorant man, professed religion, and praised God, and saug this hymn."

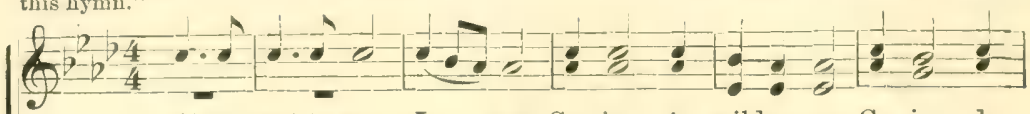

Ef ye want to see Je - sus, Go in de wilderness, Go in de

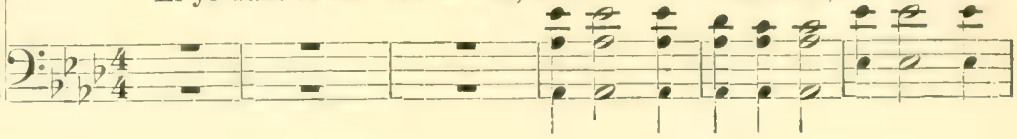

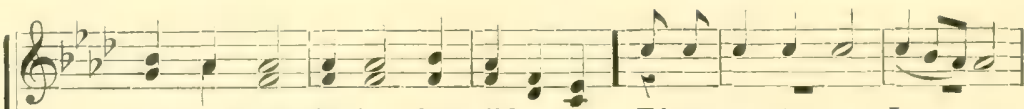
wil-der-ness, Go in the wilderness, Ef ye want to see Je - sus,

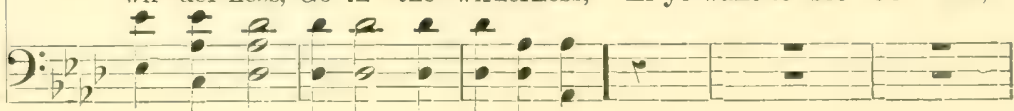
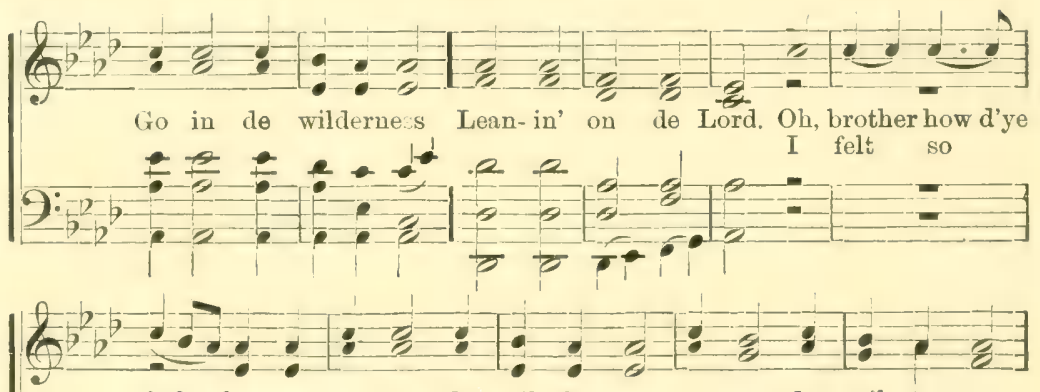

feel, when ye come out de wil-der-ness, comeout de wil-der-ness, happy when I come out de wil-der-ness, come ont de wil-der-ness,

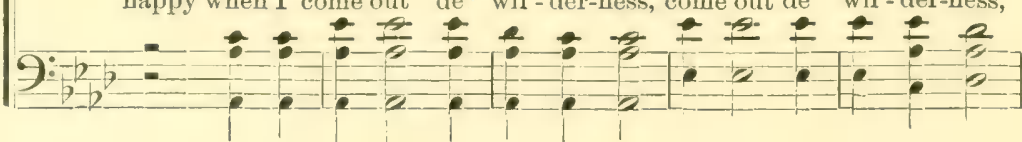

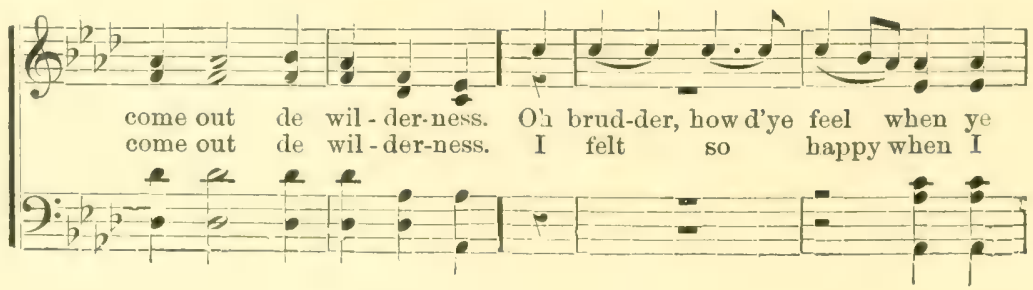




\section{gEf ye want to see $\mathfrak{J})$ sus.-Concluded.}
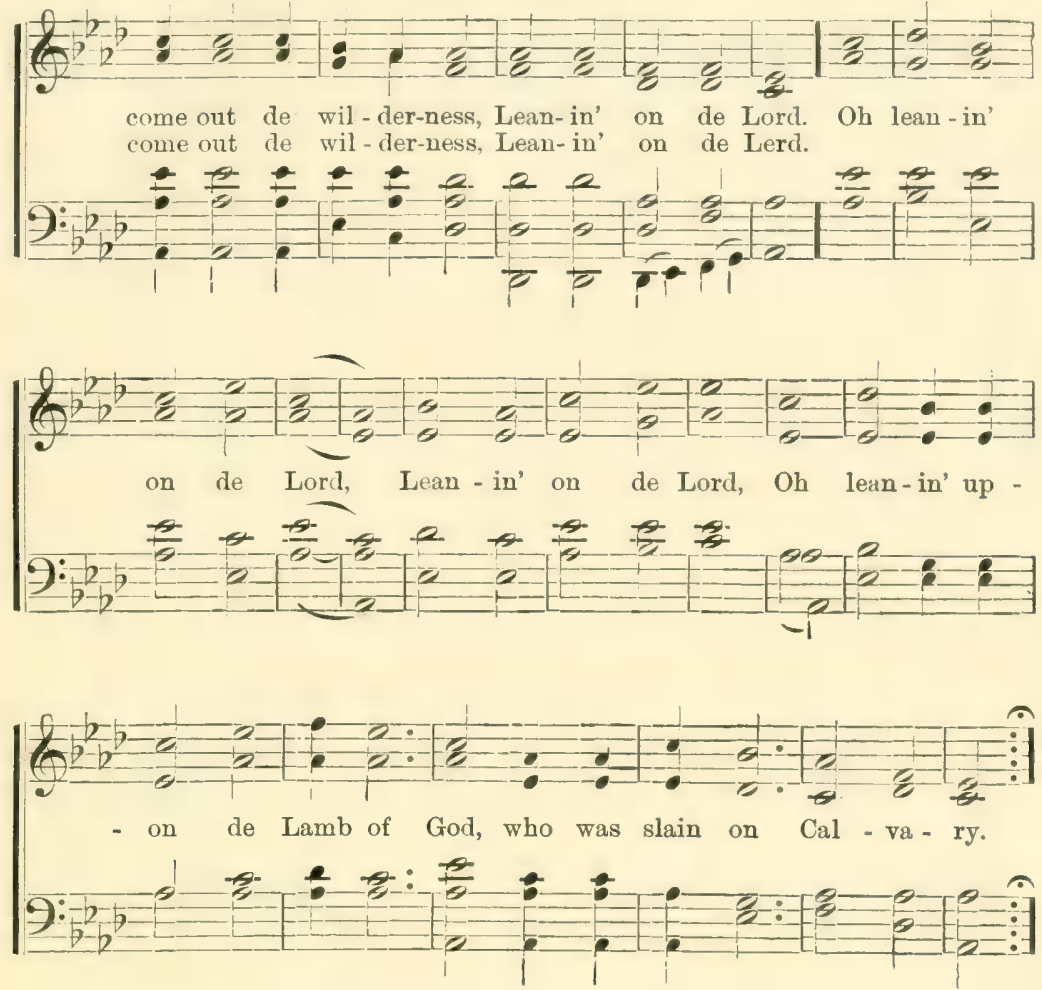

2 I shouted Hallelujah, when I come out de wildernessLeanin' on de Lord ;

I heard de angels singin', when I come out de wildernessLeanin' on de Lord ;

I heard de harps a harpin, ' when I come out de wildernessLeanin' on de Lord.

Сно.-Oh, leanin' on de Lord.

3 I heard de angels moanin', when I come out de wildernessLeanin' on de Lord ;

I heard de deb'l howlin', when I come out de wildernessLeanin' on de Lord;

I gib de deb'l a battle, when I come out de wilderness-

Leanin' on de Lord.

CHo.-Oh, leanin' on de Lord. 
(D), 界的.

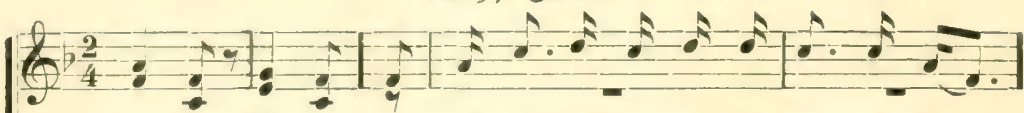

Oh, yes! Oh, yes! I tell ye, breth-er-en, a mor-tal fac', $9:-\frac{2}{54}: \frac{7}{b}:-1=$

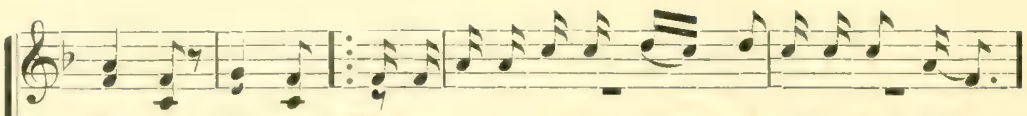

Oh, yes! Oh, yes! Ef ye want to get to heab'n, don't nebber look back, $9: \div$

(6): Oh, yes! Oh, yes! I want to know-a before I go, Oh, yes! Oh, yes! Ebbersince I hab-a been newly born.
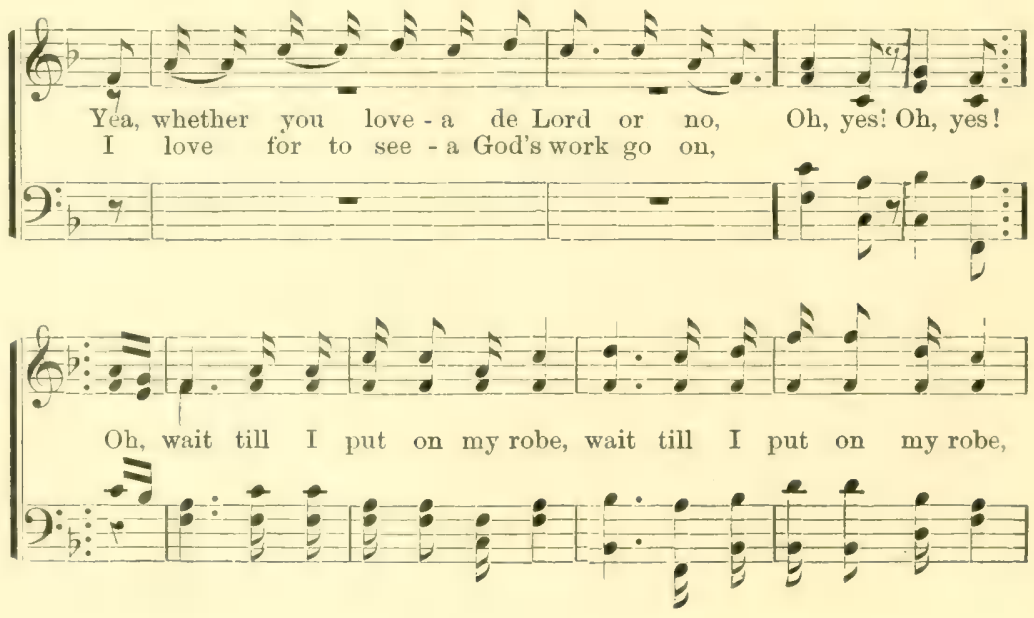
(D), 思s.-Concluded.

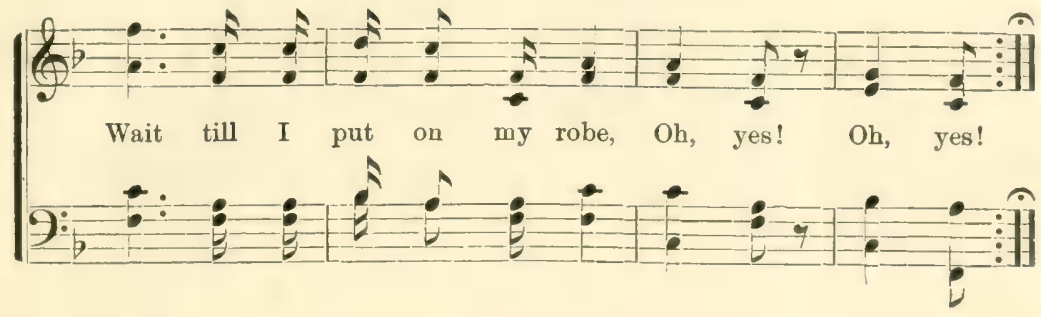

2.

Ef eber I land on de oder sho', Oh, yes, I'll nebber come here for to sing no mo', $\mathrm{Ob}$, yes;

A golden band all round my waist, $A n^{\prime}$ de palms ob vic-a-try in-a my hand, An' de golden slippers on to my feet, Gwine to walk up an' down o' dem golden street.

CHo.-Oh, wait till I put on my robe.

3.

An' my lovely bretherin, dat aint all, $\mathrm{Ob}$, yes,

I'm not done a talkin' about my Lord;

An' a golden crown a-placed on a-my head,

An' my long white robe a-come-a-dazzlin' down,

Now wait till I get on my gospel shoes,

Gwine to walk about de heaben an' a-carry de news.

CHO.-Oh, wait till I put on my robe.

\section{4.}

I'm anchored in Christ, Christ anchored in $\mathrm{me}, \mathrm{Oh}$, yes, \&c.,

All de deb'ls in hell can't-a-pluck a-me out;

An' I wonder what Satan 's grumbulin' about,

He's bound into hell, an' he can't git out. But he shall be loose an' hab his sway,

Yea at de great resurrection day.

Cно. - Oh, wait till I put on my robe.

Verses, some of which are often added as encores.

5.

I went down de hill side to make a-one prayer, $\mathrm{Ob}$, yes,
An' when I got dere, old Satan was dere, $\mathrm{Oh}$, yes,

An' what do ye t'ink he said to me? $\mathrm{Oh}$, yes,

Said, "Off from here you'd better be." $\mathrm{Oh}$, yes;

An' what for to do, I did not know, Oh, yes,

But I fell on my knees, an' I cried, Oh, Lord, $\mathrm{Oh}$, yes,

Now my Jesus bein' so good an' kind,

Yea, to de with-er-ed, halt an' blind;

My Jesus lowered his mercy down,

An' snatch-a-me from a-dem doors ob hell,

He snatch-a-me from dem doors ob hell,

An' took-a me in a-wid him to dwell.

Сно.-Oh, wait till I put on my robe.

6.

I was in de church an' prayin' loud,

An' on my knees to my Jesus bowed,

Ole Satan tole me to my face,

"I'll git you when-a-you leave dis place;"

$\mathrm{Oh}$, brother, dat scare me to my heart,

I was 'fraid to walk a-when it was dark.

CHo. - Oh, wait till I get on my robe.

7.

I started home, but I did pray,

An' I met ole Satan on de way;

Ole Satan made a-one grab at me,

But he missed my soul, an' I went free.

My sins went a-lumberin' down to hell,

An' my soul went a-leapin' up Zion's hill;

I tell ye what, brethern, you'd better not laugh,

Ole Satan 'll run you down his path;

If he runs you, as he run me,

You'll be glad to fall upon your knee.

CHo.-Oh, wait till I put on my robe. 


\section{Liur, ftlary, tiun.}
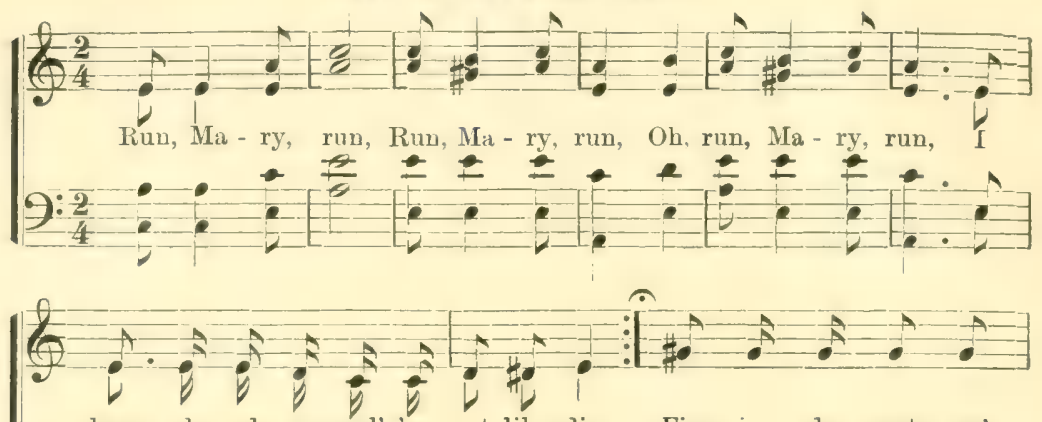

know de od - er worl' 'm not like dis.

Fire in de east, an'
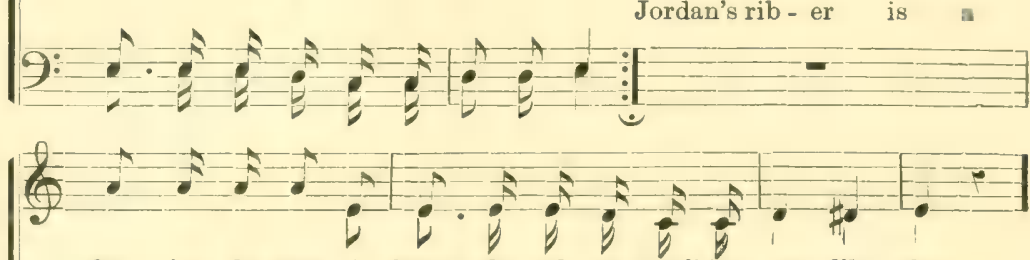

fire in de west, I know de od-er worl' $m$ not like dis,

rib - er to cross, I know de od - er worl' $m$ not like dis,

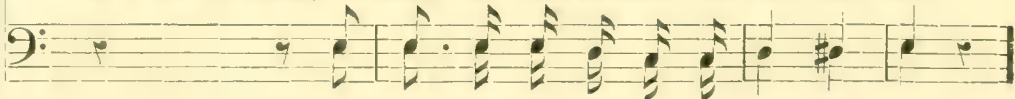

D.C. al Fine.

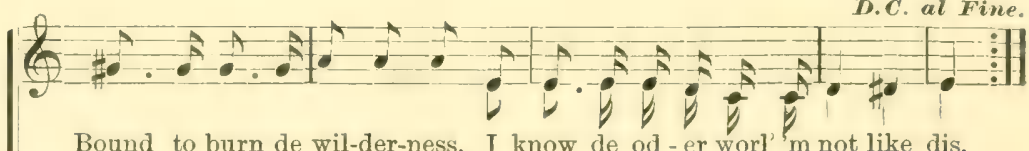

Bound to burn de wil-der-ness, I know de od-er worl' $m$ not like dis.

Stretch your rod an' come a - cross, I know, \&c.

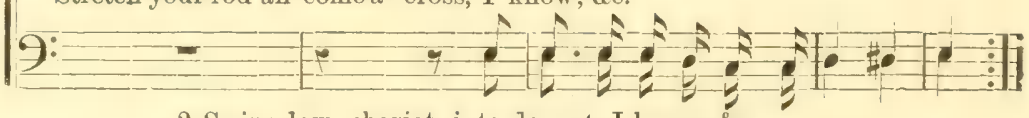

2 Swing low, chariot, into de east, I know, \&c.

Let God's children hab some peace; I know, \&c.

Swing low, chariot, into de west; I know, \&c.

Let Grod's children hab sorne rest; I know, \&c.-Сно.

3 Swing low, chariot, into de north; I know, \&c.

Gib me de gold widout de dross; I know, \&c.

Swing low, chariot, into de south; I know, \&c.

Let God's children sing and shout; I know, \&c.-Cно.

4 Ef dis day war judgment day, I know, \&c.

Ebery sinner would want to pray; I know, \&c.

Dat trouble it come like a gloomy cloud; I know, \&c.

Gader tick, an' tunder lond; I know, \&c.-Сво. 


\section{Lieligín is a ffortune.}
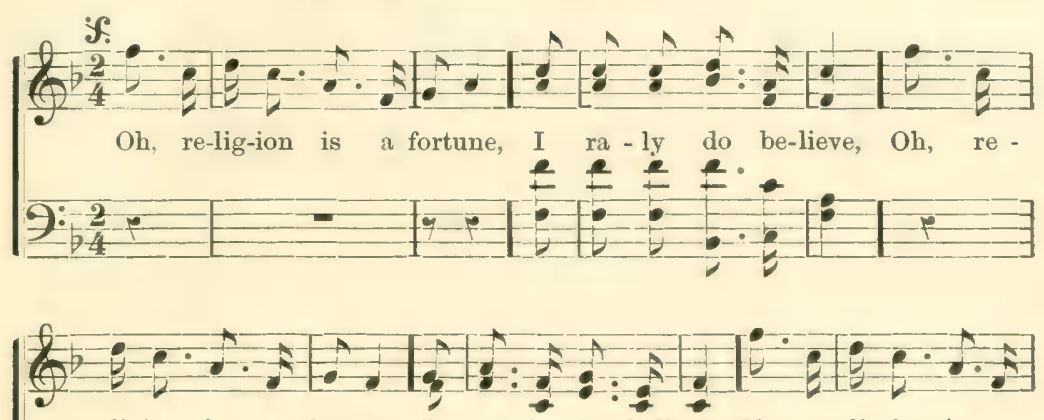

- ligion is a fortune, I ra-ly do believe, Oh, re-li-gion is a
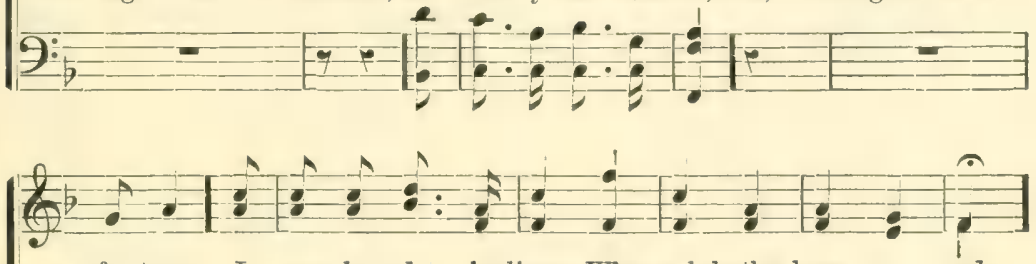

for-tune, I ra-1y do be-lieve, Whar sab-baths have no end.
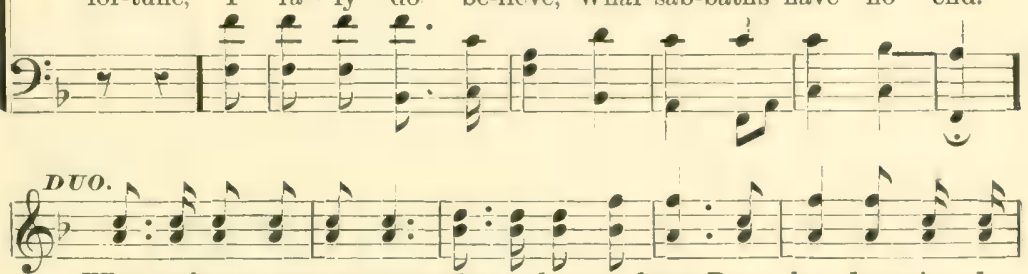

Whar ye been, poor mourner, whar ye been so long; Been low down in de

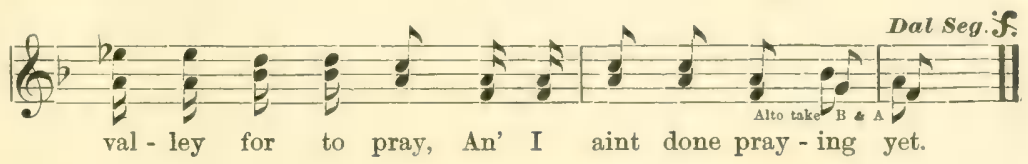

2 Gwine to sit down in de kingdom, I raly do believe, Whar Sabbaths, \&c., Gwine to walk about in Zion, I raly do believe, Whar Sabbaths, \&c.

Duo.- Whar ye ben young convert, \&c.

3 Gwine to see my sister Mary, I raly do believe, Whar Sabbaths, \&c. Gwine to see my brudder Jonah, I raly do believe.

Doo. - Whar ye ben good Christian, \&c.

4 Gwine to talk- $a$ wid de angels, I raly do believe, Whar Sabbaths, \&c., Gwine to see my massa Jesus, I raly do believe, Whar Sabbaths, \&c. 


\section{Some o' ơse ftornin's.}

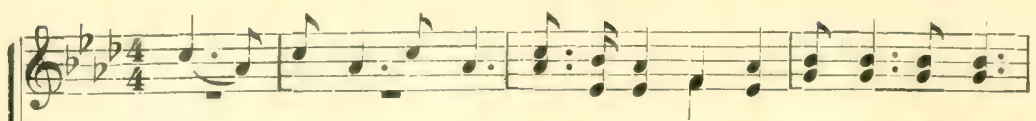

Gwine to see my moth-er some o' dese mornin's, seemy moth-er Oh, sittin' in de kingdom some o' dese mornin's, sittin in de kingdom
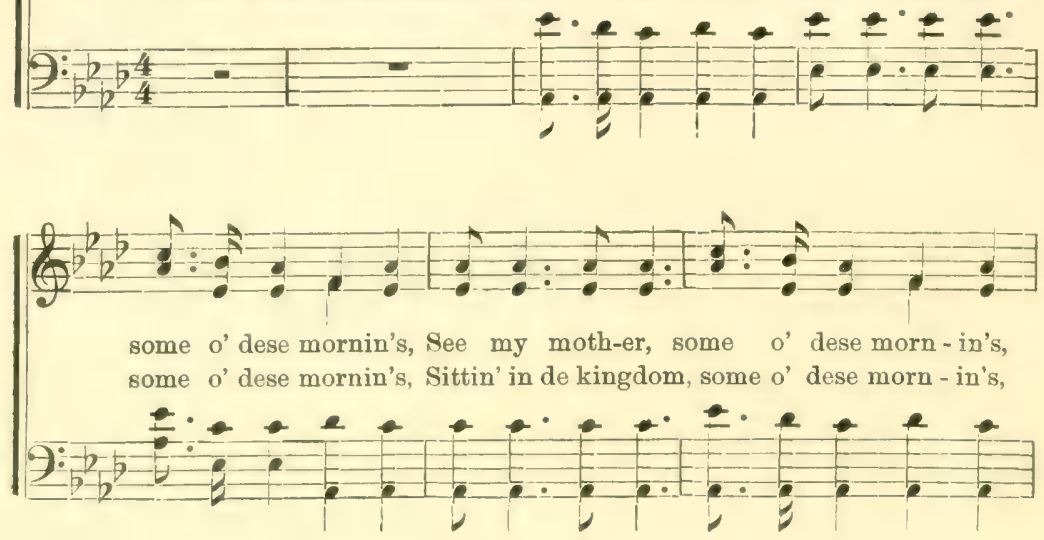

Look a -way in de hear-en, ... Look a -

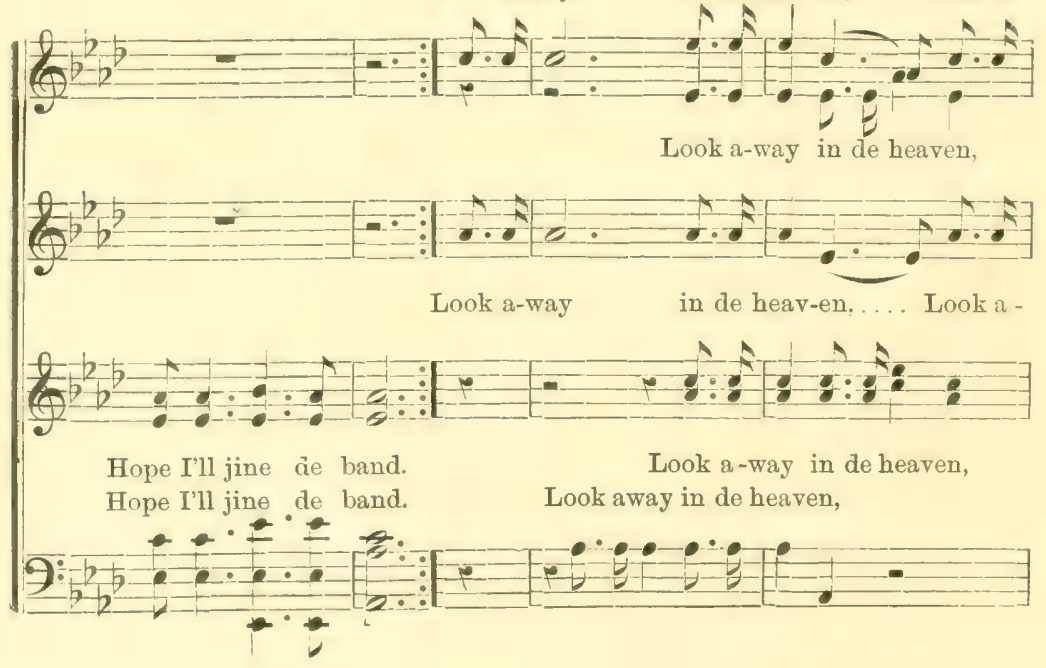




\section{Some a' aese ftlornin's.-Continued}

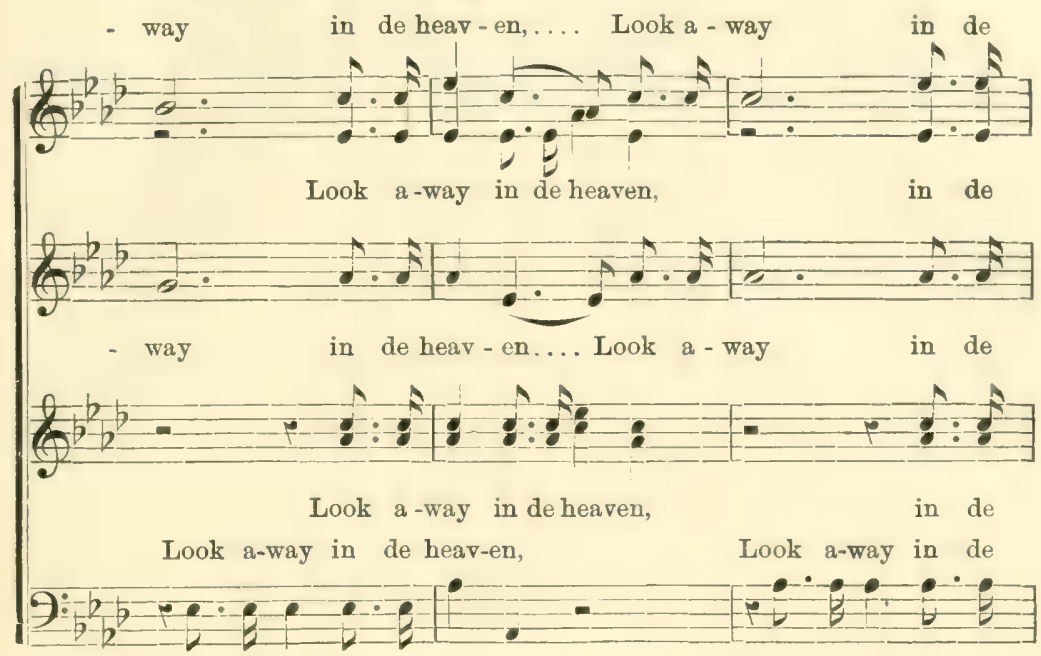

heaven, Lord, Hope I'll jine de band,

Look a-way

in de

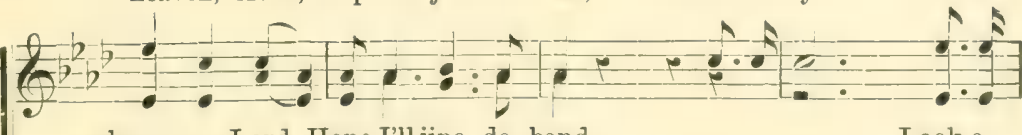

heav-en, Lord, Hope I'll jine de band,

Look a -

Look away, .................

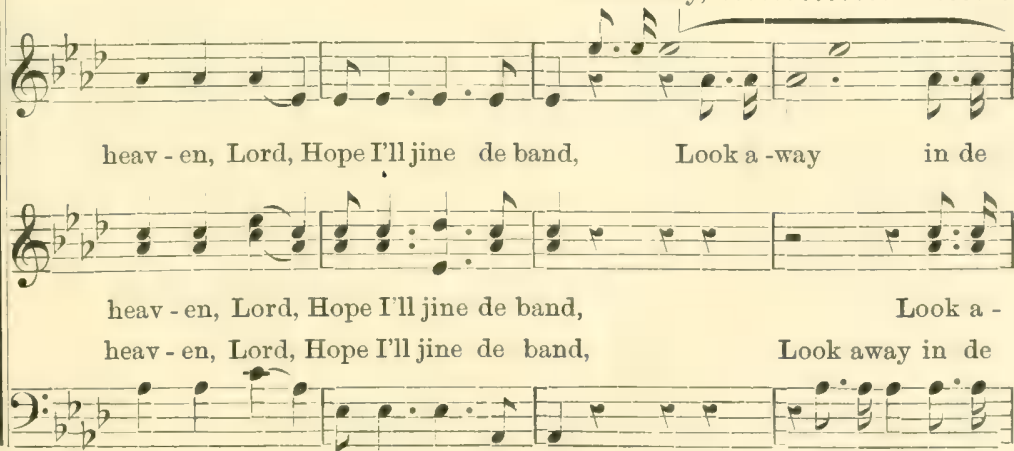


Some o' aese ftlornin's.-Concluded.

heav - en, Look a - way in de hea-ven, Look a-
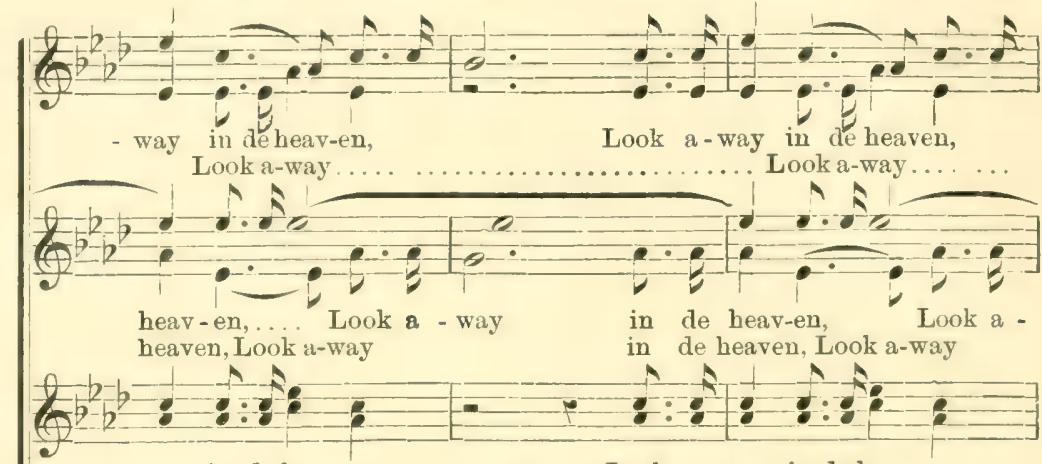

- way in deheav-en, Look a-way in de heav-en, heav-en, Look a-way in de heaven,
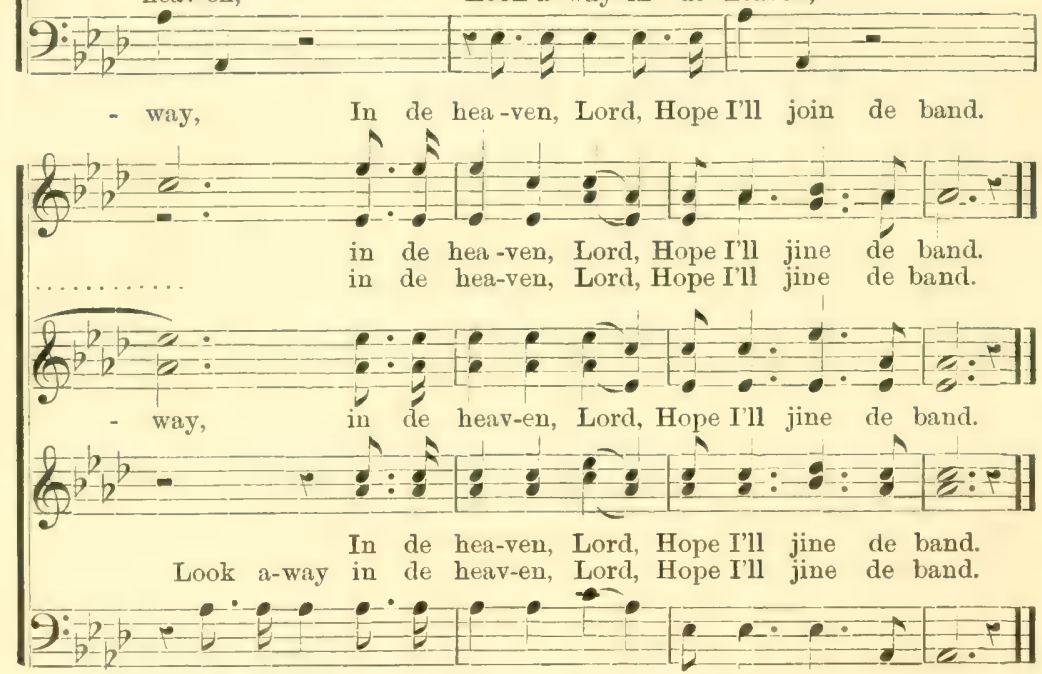

2 Gwine to see my brother some $o$ ' dese mornin's;

Oh, shouting in de heaven some o' dese mornin's,

Hope I'll jine de band. CHo.-Look away.

3 Gwine to walk about in Zion, some o' dese mornin's,

Gwine to talk-a with de angels some o'dese mornin's, Hope I'll jine de band. CHо.-Look away.

4 Gwine to talk de trouble ober some o' dese mornin's, Gwine to see my Jesus some o' dese mornin's, Hope I'll jine de band. CHo._Look away. 


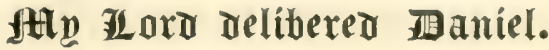

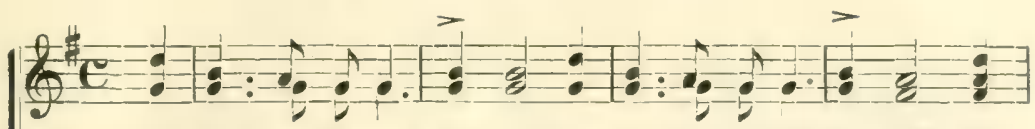

My Lord de-lib-ered Dan-iel, My Lord de-lib-ered Dan-iel, My

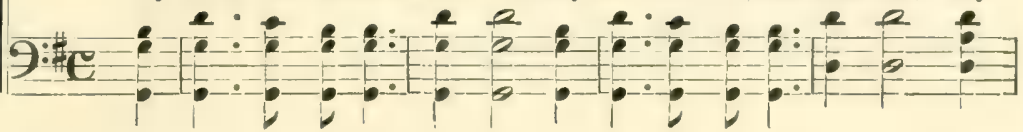

Fine.

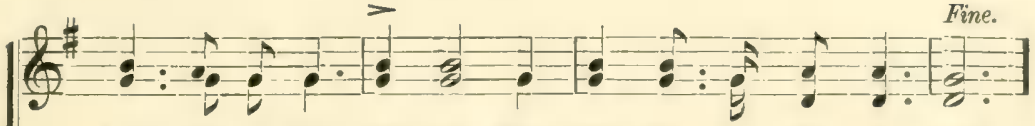

Lord de-lib-ered Dan-iel; Why can't he de - lib - er me?
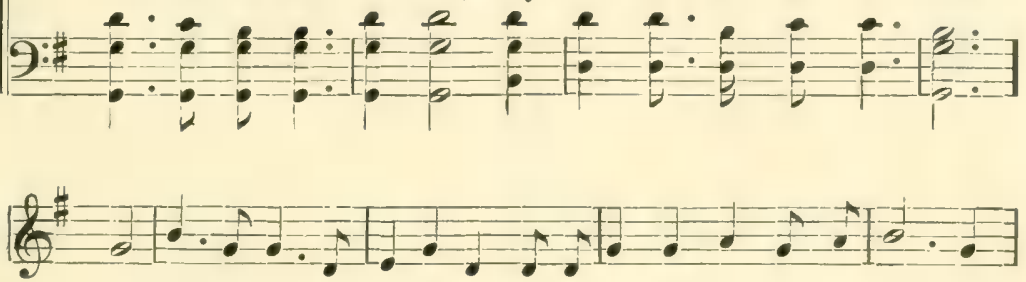

I met a pil-grim on de way, An' I ask him whar he's a gwine. I'm

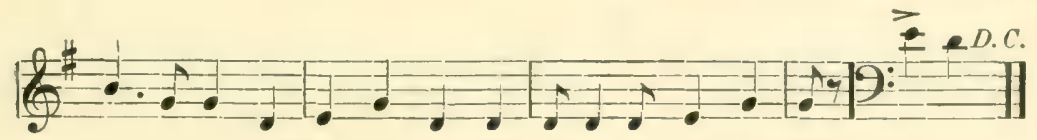

bound for Canaan's hap - py lan', An' dis is de shout-ing band. Go on!

\section{2.}

Some say dat John de Baptist

Was nothing but a Jew,

But de Bible doth inform us

Dat he was a preacher, too; Yes, he was!

Сно.--My Lord delibered Daniel.

3.

$\mathrm{Oh}$, Daniel cast in de lions den, He pray both night an' day,

De angel came from Galilee,

An' lock de lions' jaw.

Dat's so.

Сно.-My Lord delibered Daniel.
4.

He delibered Daniel from de lions' den, Jonah from de belly ob de whale, And de Hebrew children from de fiery furnace,

And why not ebery man? $\mathrm{Oh}$, yes!

Сно.-My Lord delibered Daniel.

5.

De richest man dat eber I saw

Was de one dat beg de most,

His soul was filled wid Jesus,

And wid de Holy Ghost.

Yes it was!

Сно.--My Lord delibered Daniel. 


\section{(O), wasn't dat a wiore liber.}

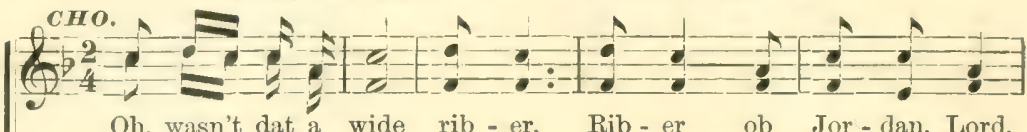

Oh, wasn't dat a wide rib - er, Rib - er ob Jor-dan, Lord,
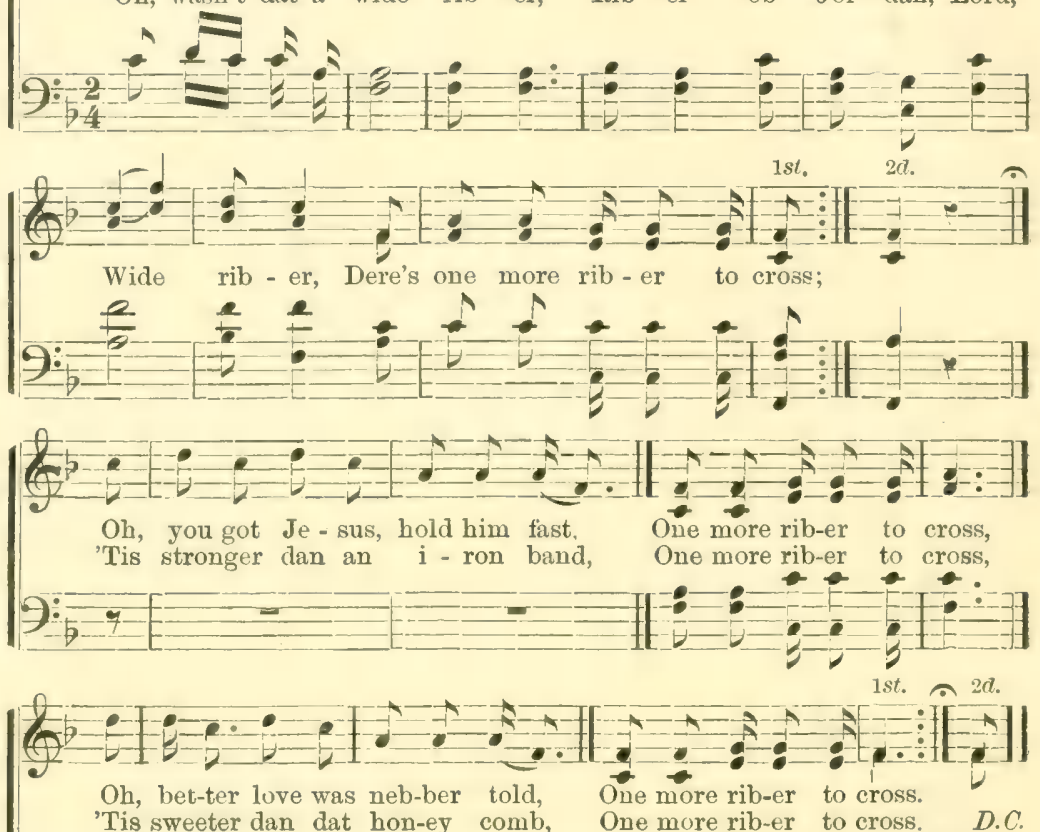

Oh, bet-ter luve was neb-ber told,

One more rib-er to cross.

D.C.

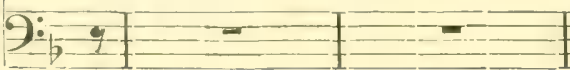

2.

Oh, de good ole chariot passing by, One more riber to cross,

She jarred de earth an' shook de sky, One more, \&c.,

I pray, good Lord, shall I be one? One more, \&c.,

To get up in de chariot, trabbel on, One more, \&c.

Сно. - Oh, wasn't dat a wide riber? \&c. 3.

We're told dat de fore-wheel run by love, One more, \&c.,

We're told dat de hind wheel run by faith, One more, \&c.,
I hope I shall get dere bimeby,

One more, \&c.

To jine de number in de sky,

One more, \&c.

Сно. - Oh, wasn't dat a wide riber? \&c. 4.

$\mathrm{Oh}$, one more riber we hab to cross, One more, \&c.,

'Tis Jordan's riber we hab to cross, One more, \&c..

Ob, Jordan's riber am chilly an' cold, One more, \&c.,

But I got de glory in-a my soul, One more. \&c.

Сно.-Ob, wasn't dat a wide riber? \&ै. 


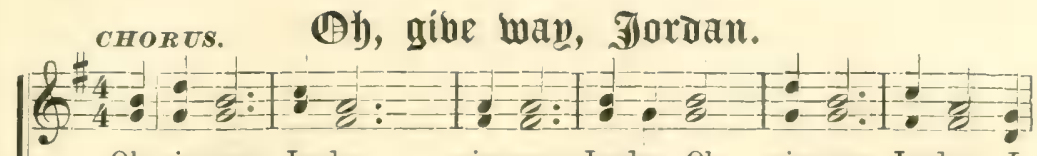

Oh, give way, Jordan, give way, Jordan, Oh, give way, Jordan, I Jorlan, give way, Jordan, give way,
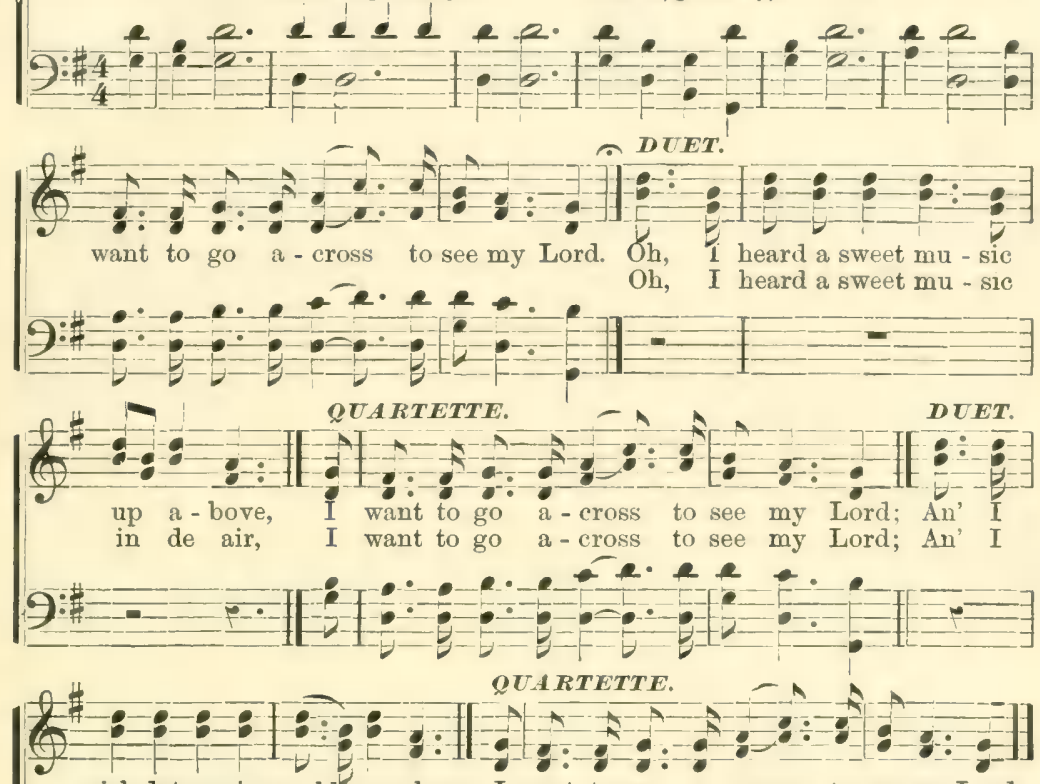

wish dat music would come here, I want to go a-cross to see my Lord. wish dat music would come here, I want to go a - cross to see my Lord.

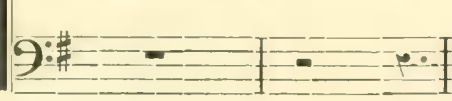

2.

Oh, stow back, stow back de powers of hell, I want to go across to see my Lord, And let God's children take de field, I want to go across to see my Lord. Now stan' back Satan, let me go by, I want to go across, \&c.,

Gwine to serve my Jesus till I die, I want to go across, \&c.-CHo.

$$
3 .
$$

Soon in de mornin' by de break ob day, I want to go across, \&c.,

See de ole ship ob Zion sailin' away, I want to go across, \&c.,

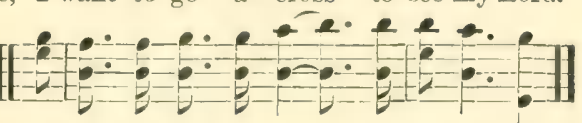

Now I must go across, an' I shall go across,

I want to go across, \&c.,

Dis sinful world I count but dross,

I want to go across, \&c.-CHо.

4.

$\mathrm{Oh}, \mathrm{I}$ heard such a lumbering in de skye I want to go across, \&c.,

It make a-me t'ink my time was nigh, I want to ge across, \&c.,

Yes, it must be my Jesus in de cloud, I want to go across, \&c.,

I nebber heard him speak so loud-I want to go across, \&c.-Сно. 


\section{Ioth Saw.}

CHORUS.
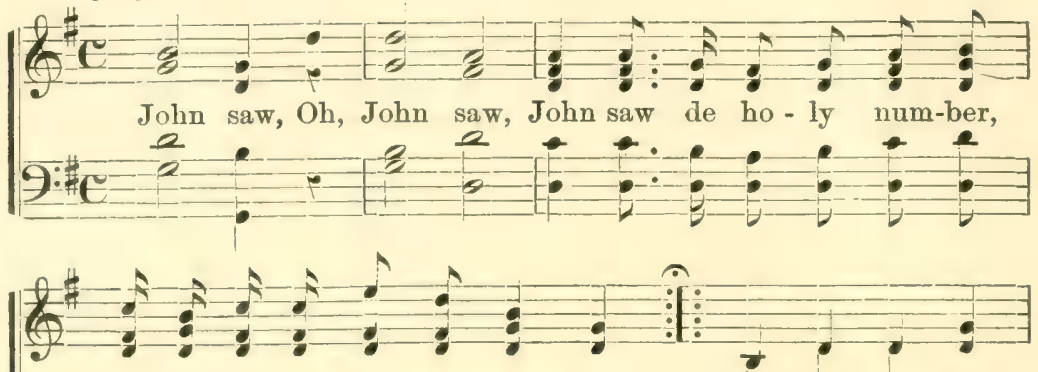

Set-tin on de gold - en aI - tar. 1. Wor - thy, wor - thy
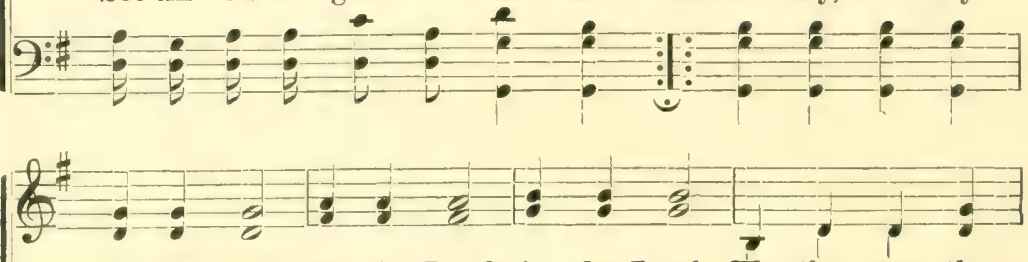

is the Lamb, is the Lamb, is the Lamb, Wor-thy, wor - thy
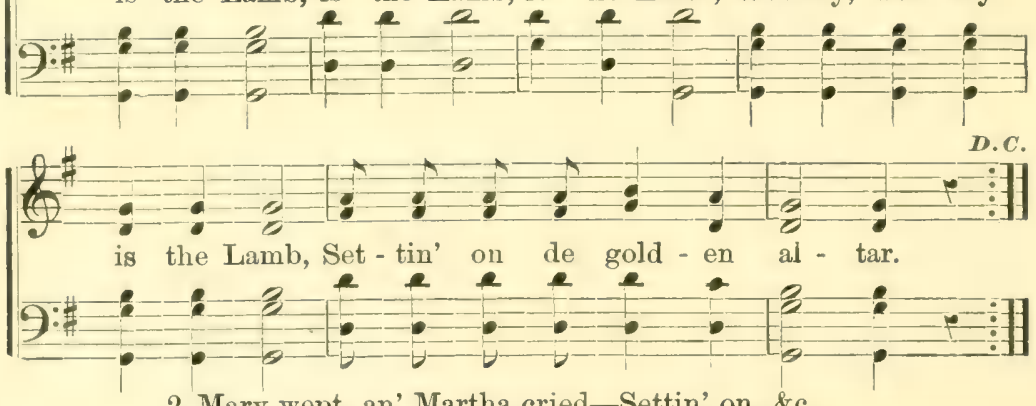

2 Mary wept, an' Martha cried-Settin' on, \&c.

To see de'r Saviour crucified-Settin' on, \&c.

Weepin' Mary, weep no more-Settin' on, \&c.

Jesus say He gone before-Settin' on, \&c.

Сно.-John saw, \&c.

3 Want to go to hebben when I die-Settin' on, \&c.

Sbout salvation as I fly-Settin' on, \&c.

It's a little while longer here below-Settin' on, \&c.

Den-a home to glory we shall go-Settin' on, \&c.

Сно.-John saw, \&c. 


\section{Zing JEmanuel.}

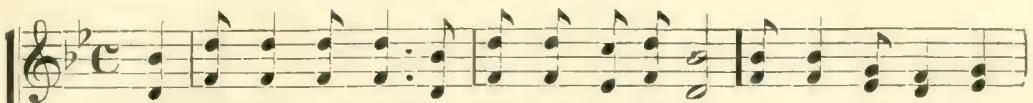

1. Oh, who do you call de King E-man-u-el; I call my Je-sus

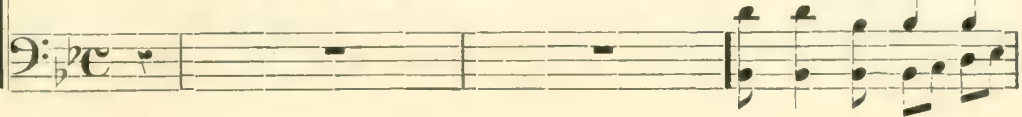

CHORUS.

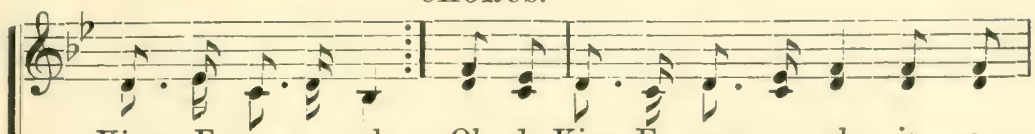

King E-man-u - el. Oh de King E-man-u-el is a
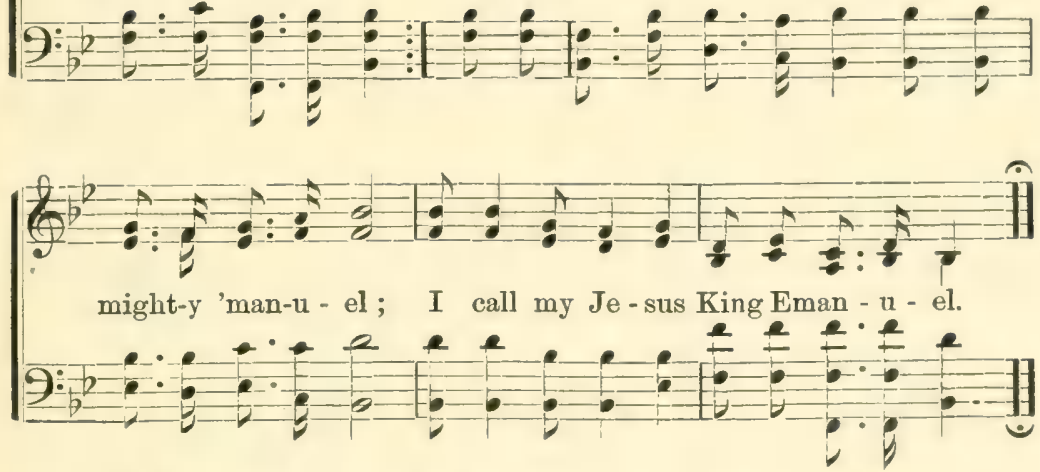

$2 \mathrm{Oh}$, some call Him Jesus ; but I call Him Lord,

I call my Jesus King Emanuel ;

Let's talk about de hebben, an' de hebben's fine t'ings,

I call my Jesus King Emanuel.

Сно.-Oh de King Emanuel, \&c.

3 Oh steady, steady, a little while;

I call my Jesus King Emanuel ;

I will tell you what my Lord done for me;

I call my Jesus King Emanuel.

CHo. - Oh de King Emanuel, \&c.

4 He pluck-a my feet out de miry clay;

I call my Jesus King Emanuel ;

He sot dem a-on de firm Rock o' Age;

I call my Jesus King Emanuel.

CHo.-Oh de King Emanuel, \&c. 


\section{CHORUS.}

\section{Jige ole Sljeep tone know do hoad.}

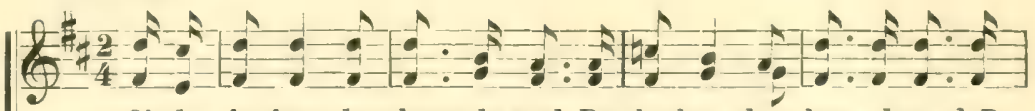

Oh de ole sheep done know de road, De ole sheep done know de road, De
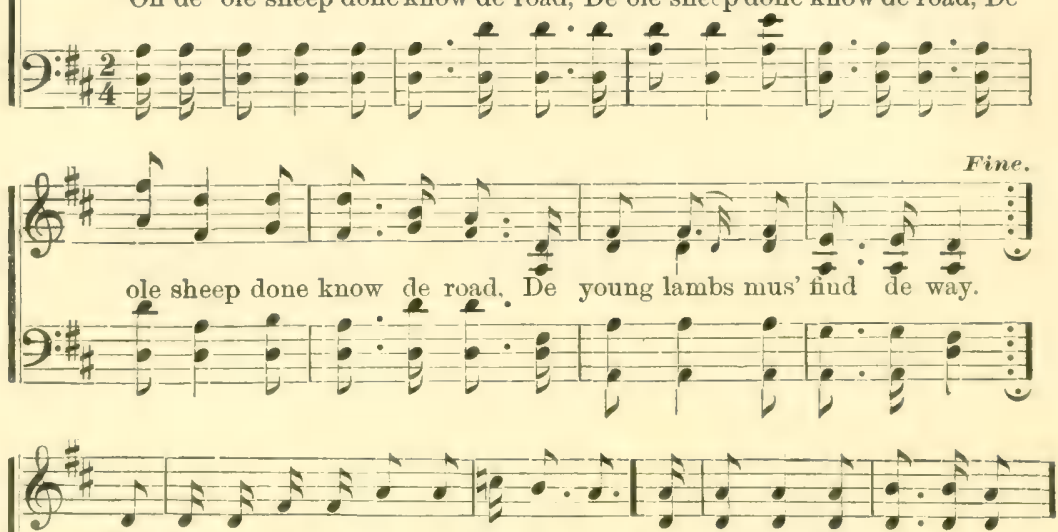

$\mathrm{Ob}$, soon-er in de mornin' when I rise, De young lambs mus' find de way.

My brudder aint ye got yer counts all sealed, De young lambs, \&c.
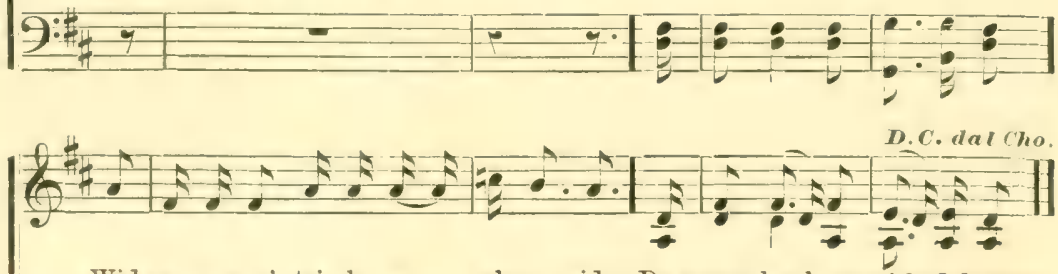

Wid crosses an' tri-als on eb-ry side, De young lambs mus' find de way.

You'd bet-ter go get em 'fore ye leave dis field, De young lambs, \&c.

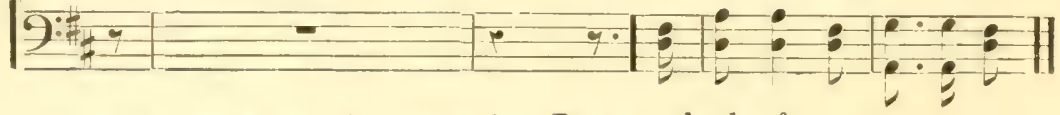

$2 \mathrm{Oh}$, shout my sister, for you are free, De young lambs, \&c.,

For Christ hab bought your liberty, De voung lambs, \&c.,

I raly do believe widout one doubt, De young lambs, \&c.,

Dat de Christian hab a mighty right to shout, De young lambs, dc.

Cно. - Oh, de ole sheep, \&e.

3 My brudder, better mind how you walk on de cross, De young lambs, \&c.s

For your foot might slip, an' yer soul git lost, De young lambs, \&c.,

Better mind dat sun, and see how she run, De young lambs, \&c.,

An' mind don't let her catch ye wid yer works undone, De young lambs, \&c.

Сво.-Oh, de ole sheep, \&c. 


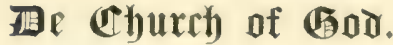
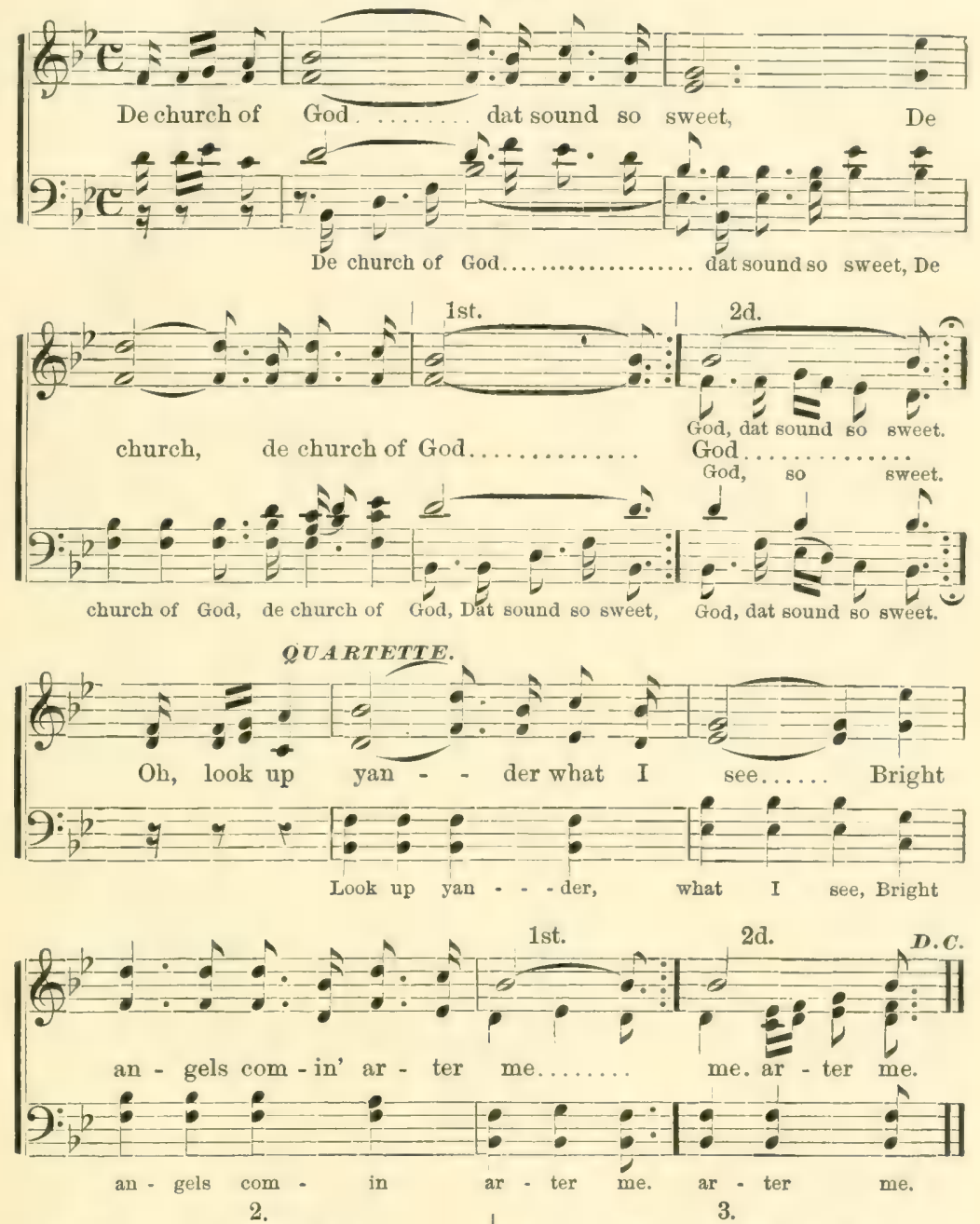

Oh, Jesus tole you once before, To go in peace an' sin no more; Oh, Paul an' Silas bound in jail, Den one did sing, an' de oder pray. Сно.-De church ob God, \&c.
Oh, did you hear my Jesus say "Come unto me, I am de way ;"

Oh, come along, Moses, don't get lost, $\mathrm{Oh}$, stretch your rod, an' come across. CHо.-De church ob God, \&c. 


\section{Bright Sparkles in ine Churchyaro.}

This peculiar but beautiful medley was a great favorite among the hands in the tobacco factories in Danville, Va.
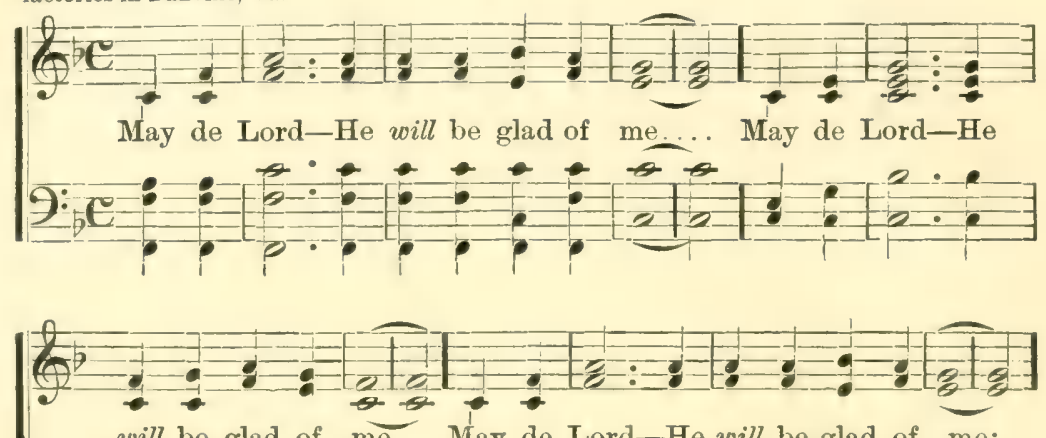

will be glad of me.. May de Lord-He will be glad of me;
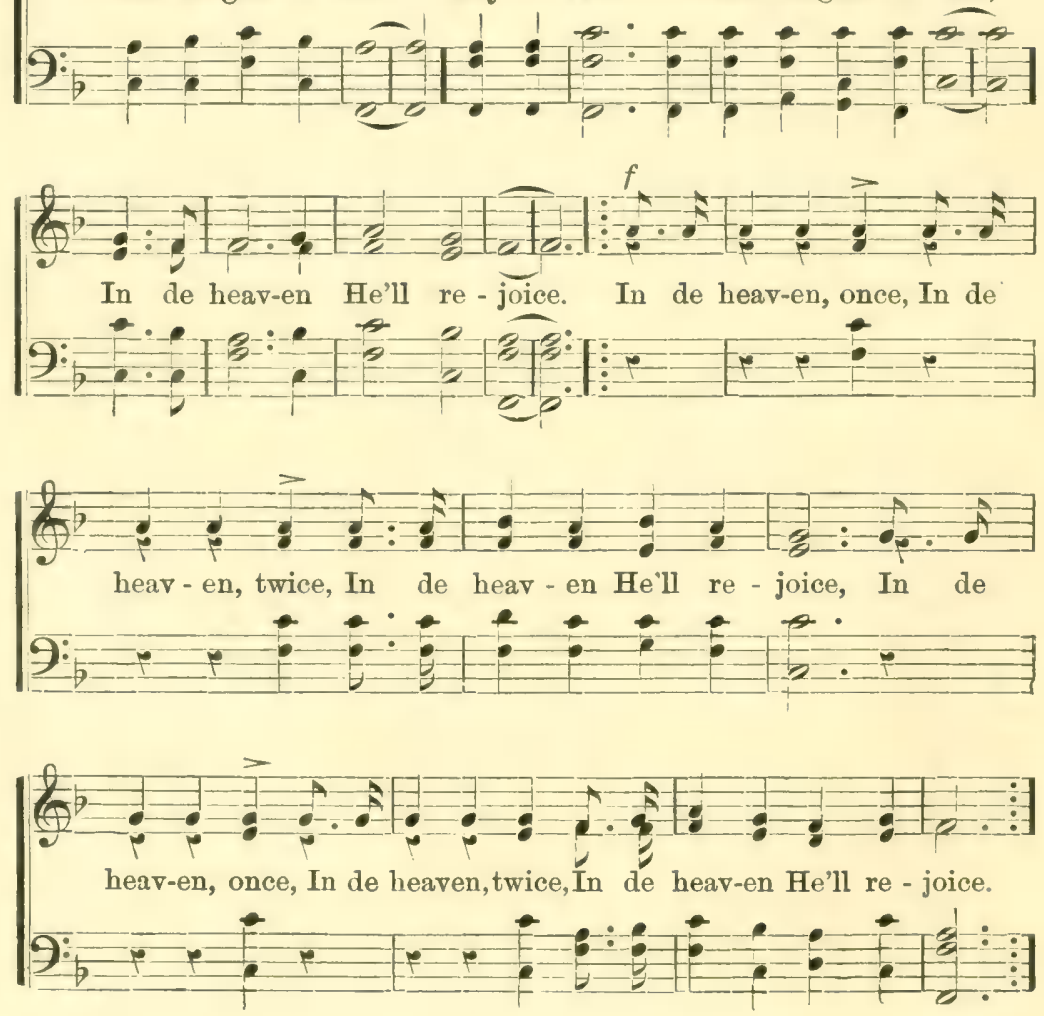
bright Sparkles in de Cyurchnard.-Continued.
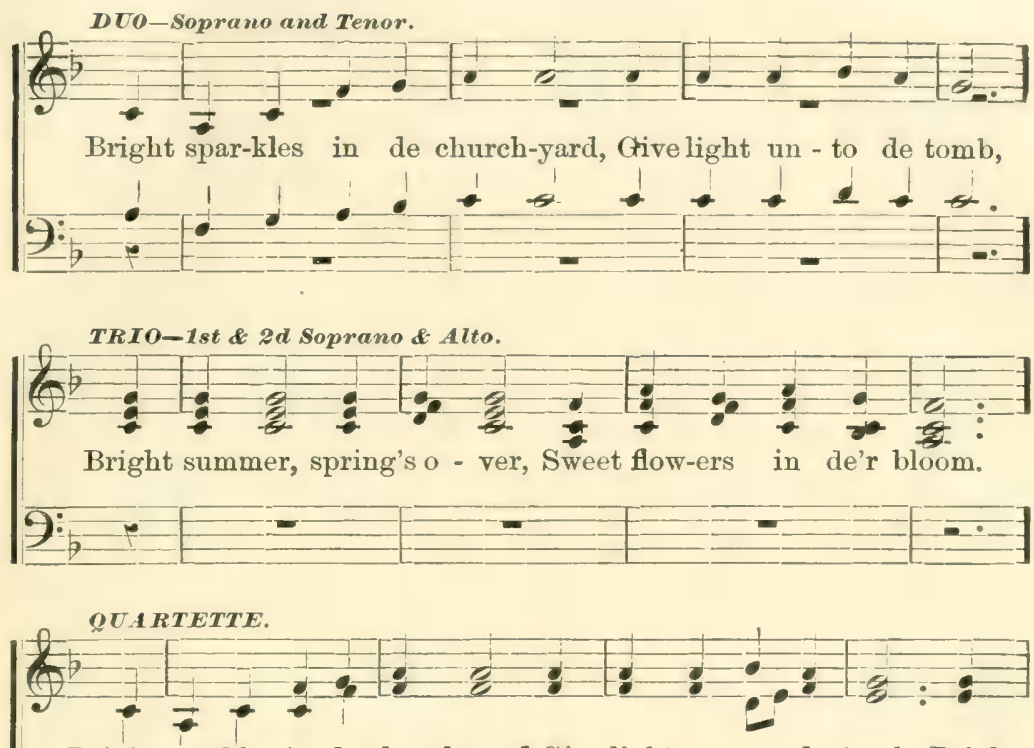

Bright sparkles in de church-yard Give light un - to de tomb, Bright
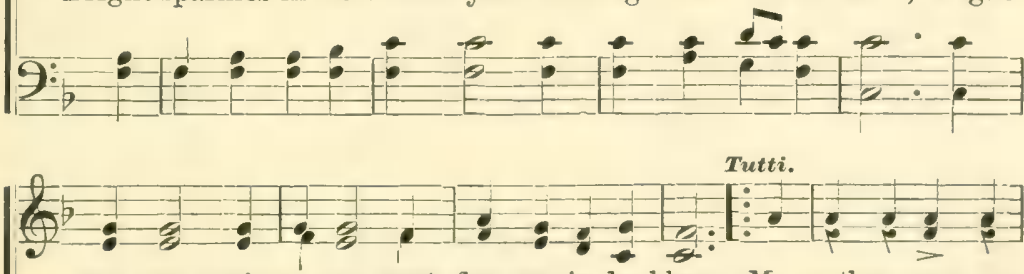

sum-mer, springs over, sweet flow-ers in der bloom. My mother, once, my
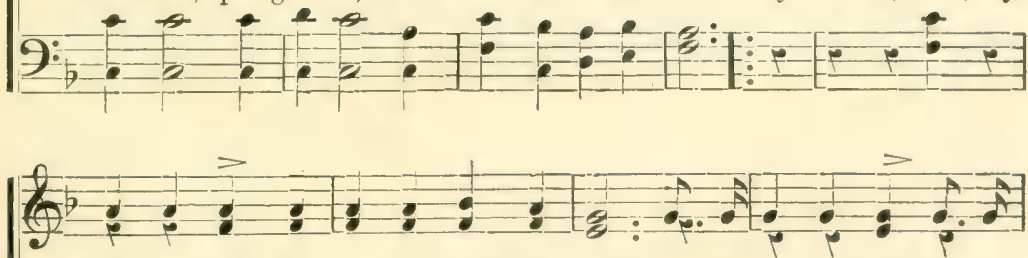
mother, twice, my mother she'll re-joice. In de heaven, once, in de

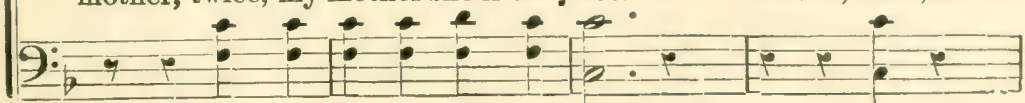


Hright Sparkles in oe êtusthard.-Continued.

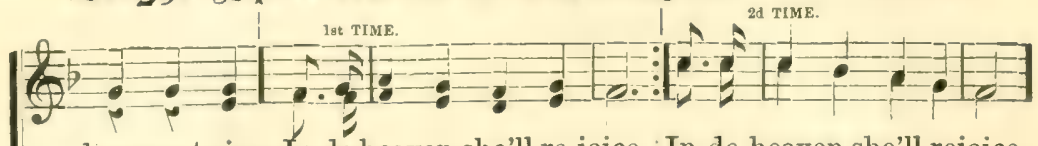
heaven, twice, In dé heaven she'll re-joice, 'In de heaven she'll rejoice.
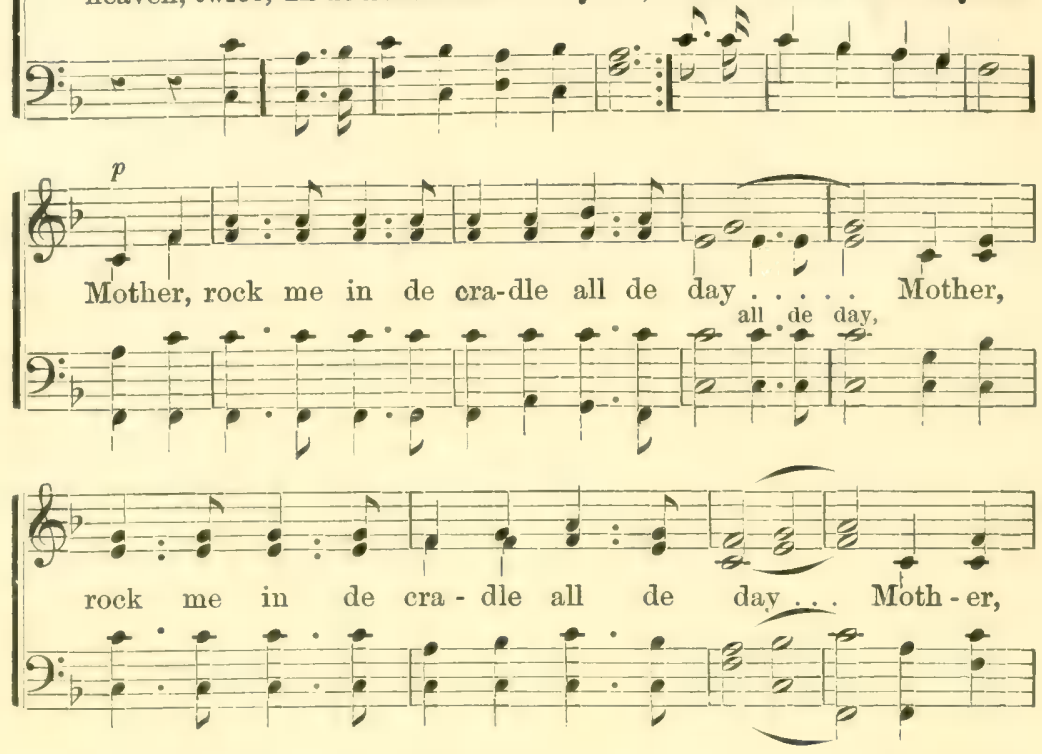

rock me in de cra - dle all de day all de day, Moth-er,
90

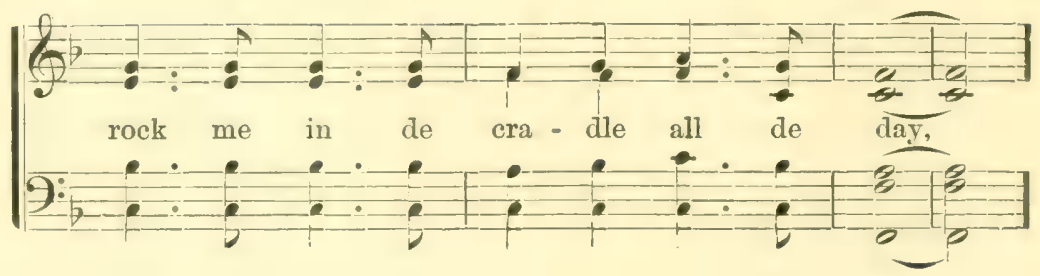


Bright Sparkles in de (C)urchyard.-Continued.

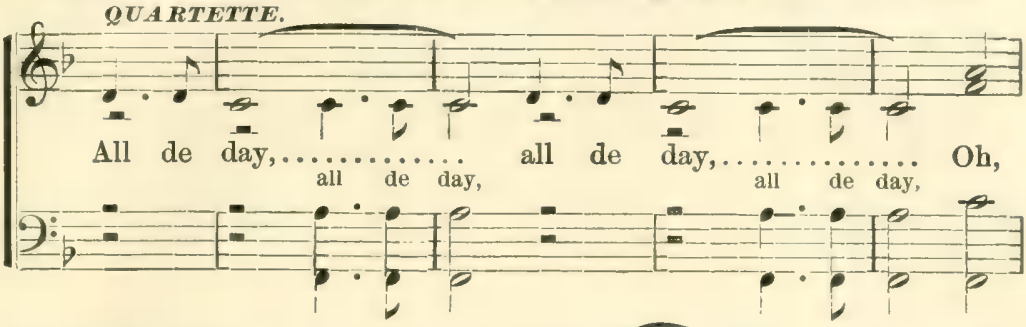

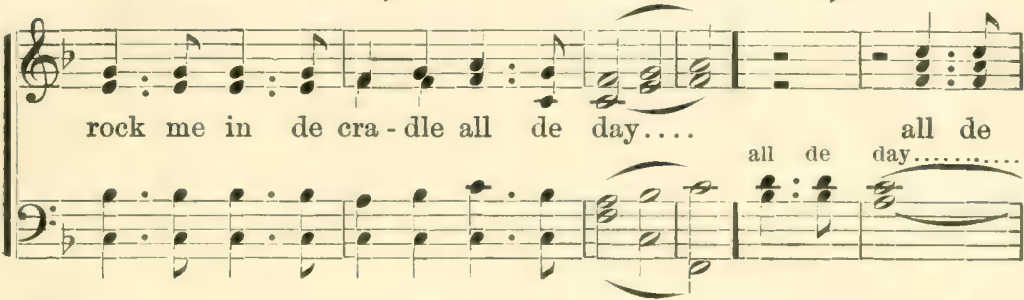
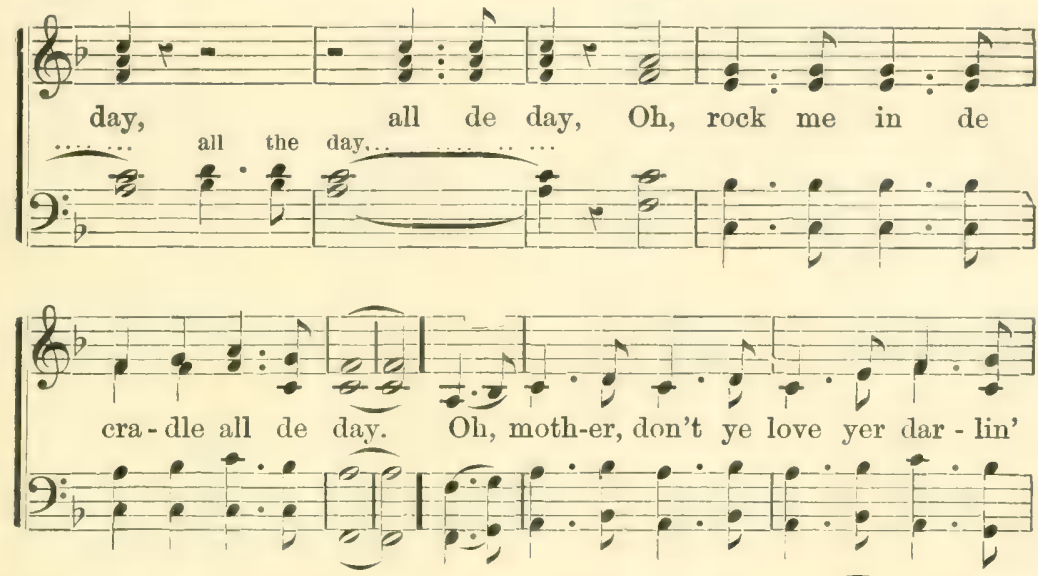

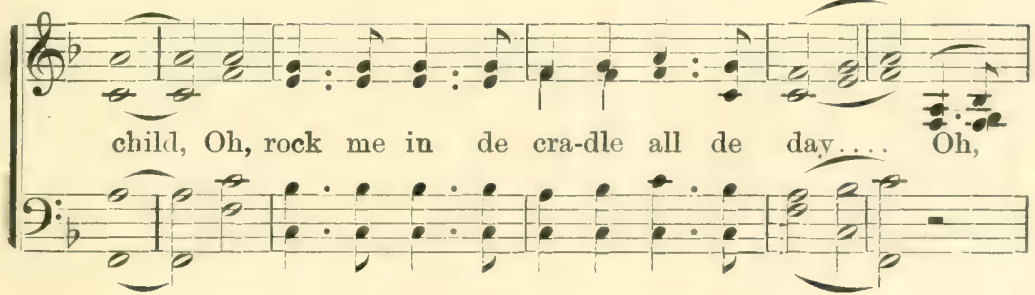


Zrígt Sparkles in oe êturchyard.-Continued.
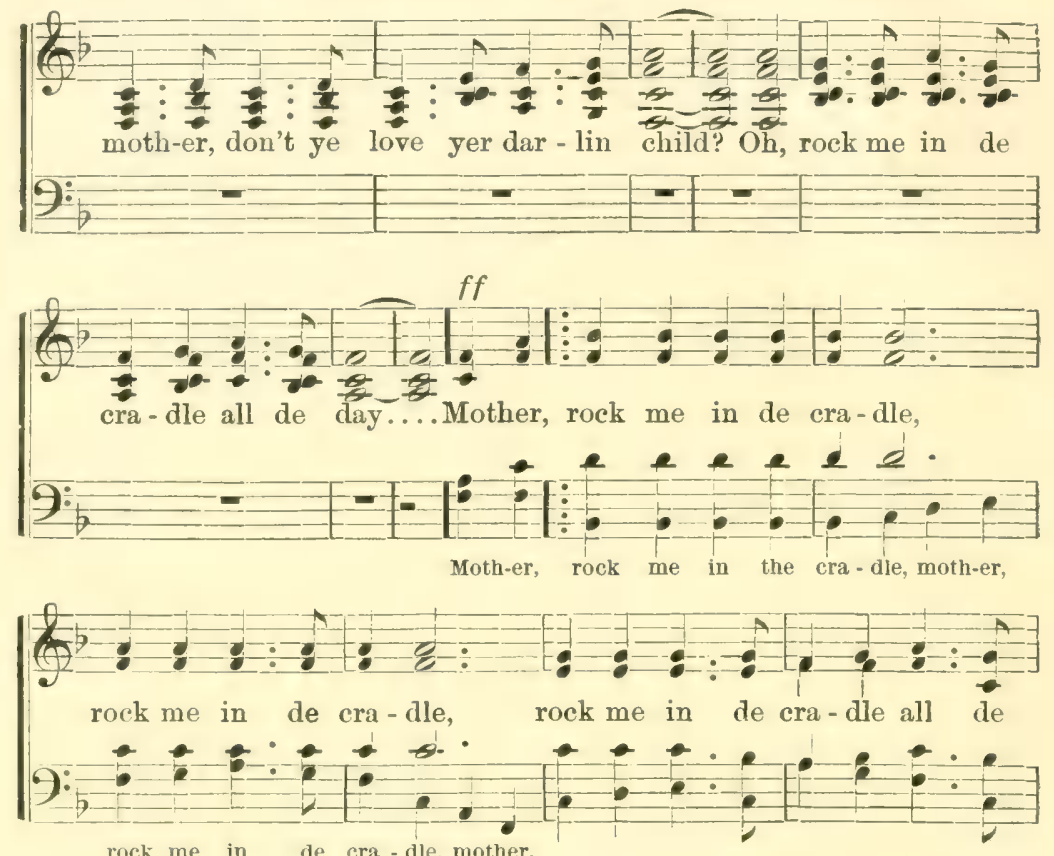

rock me in de cra - dle, mother,

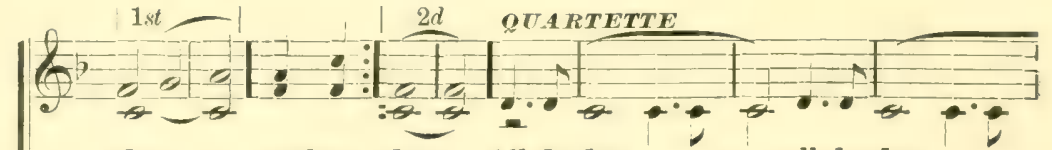

day.... mother, day. All de day......... all de day.......
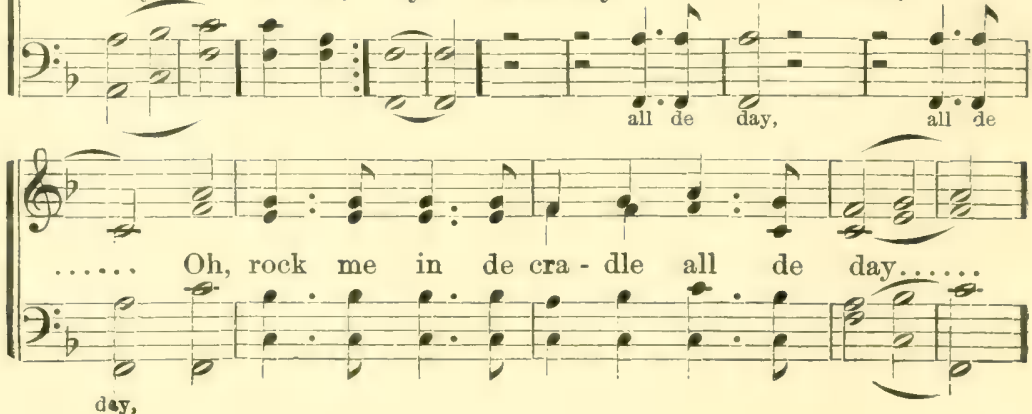
Bright Sparkles in oe erburbyard.-Concluded.
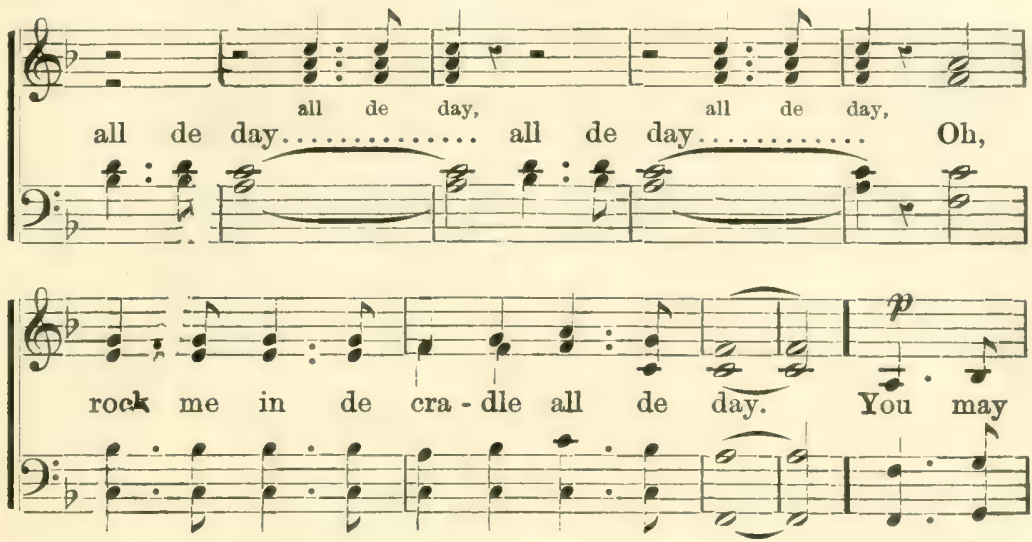

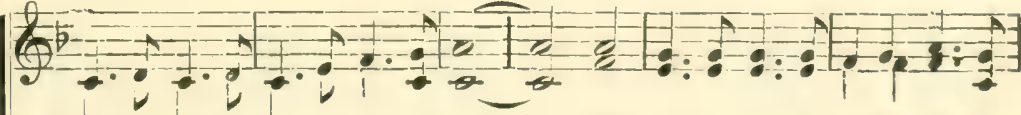

lay me down to sleep, my mother dear, Oh, rock me in de oradle all de

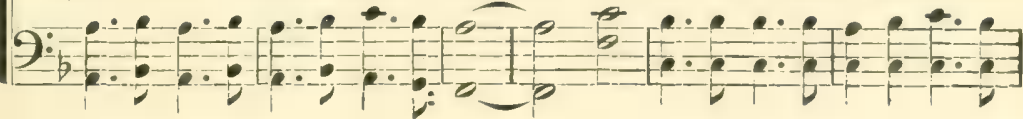

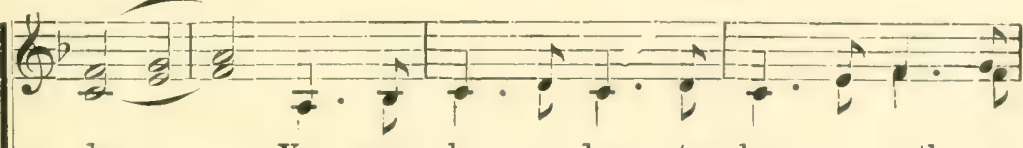

day,..... You may lay me down to sleep, my moth - er

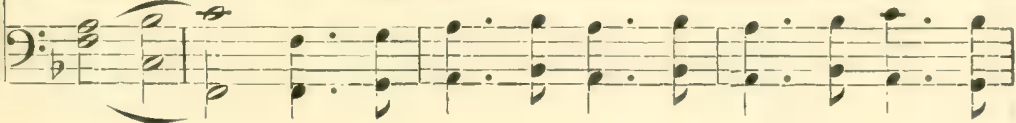

$\left(\frac{6}{2}\right)_{1}^{2}$

dear, $\mathrm{Oh}$, rock $m e$ in de cra-dle all de day...

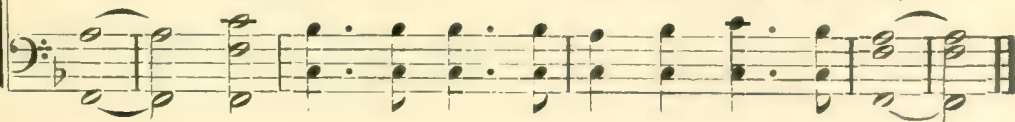




\section{J)ugnent 刃ay is a=rollin' around.}

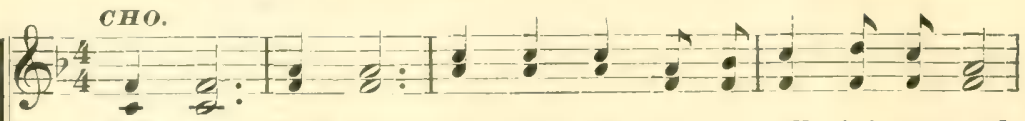

Judgment, Judgment, Judgment day is a-roll-in' a-round,

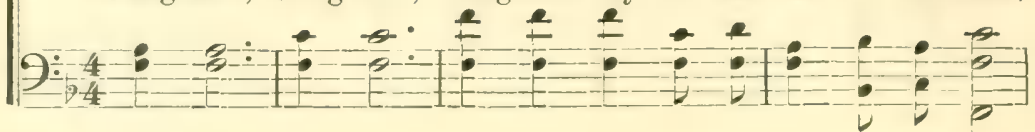

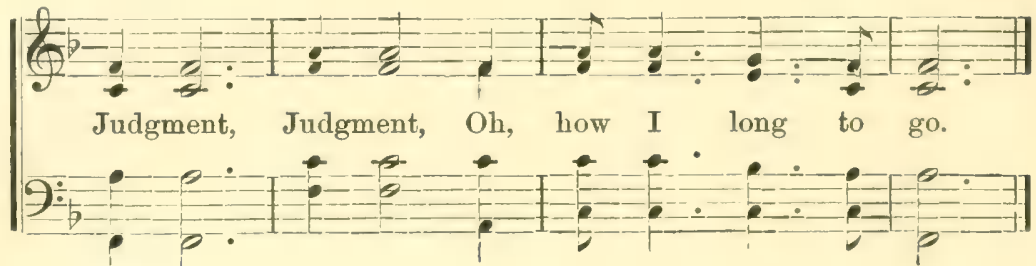

SOLO.

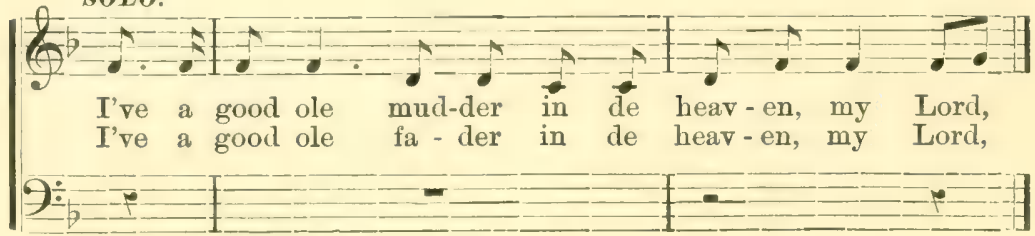

TUTTT.

Oh, how I long to go dere too; I've a good ole mudder in de

Oh, how I long to go dere too; I've a good ole fa-der in de

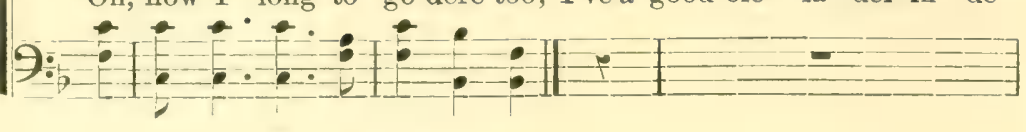

TUTTI.

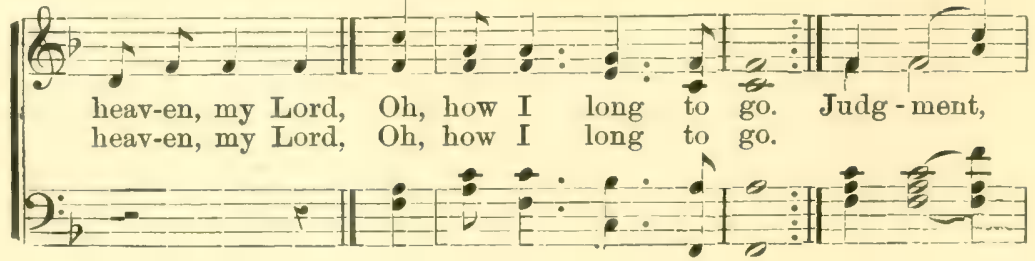


\$) ungment 刃an is a=rollin' around.-Concluded.
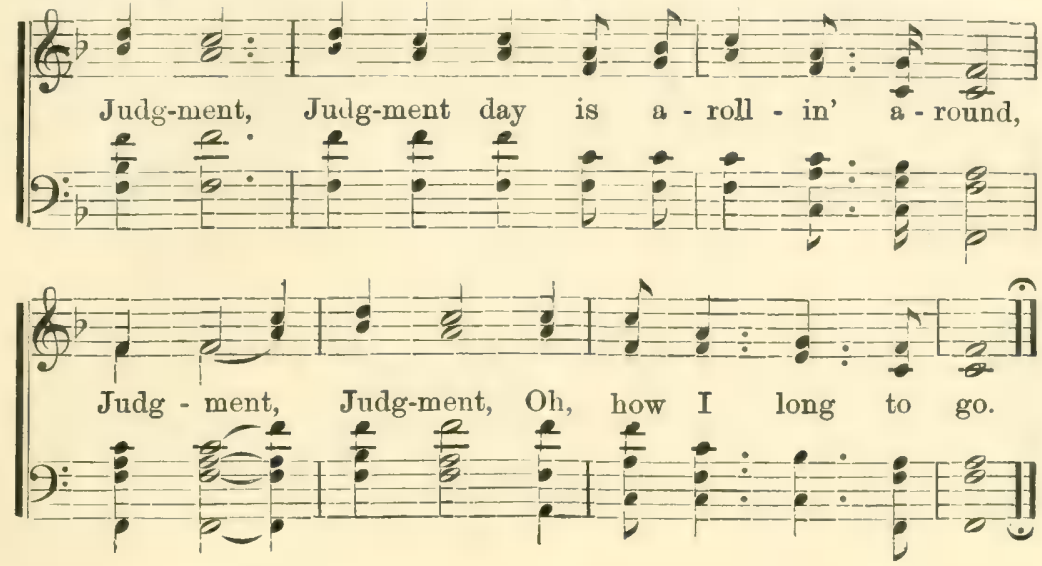

2.

Dar's a long white robe in de heaven for me,

Oh, how I long to go dere too;

Dar's a starry crown in de heaven for me,

Oh, how I long to go.

My name is written in de book ob life,

Oh, how I long to go dere too,

Ef you look in de book you'll fin'em dar,

Oh, how I long to go.

3.

Brudder Moses gone to de kingdom, Lord,

Oh, how I long to go dere too;

Sister Mary gone to de kingdom, Lord,

Oh, how I long to go.

Dar's no more slave in de kingdom,

\section{Lord,}

Oh, how I long to go dere too, All is glory in de kingdom, Lord,

$\mathrm{Oh}$, how I long to go.
4.

My brudder build a house in Paradise,

Oh, how I long to go dere too ;

He built it by dat ribber of life,

Oh, how I long to go.

Dar's a big camp meetin' in de kingdom, Lord,

$\mathrm{Oh}$, how I long to go dere too,

Come, let us jine dat a heavenly crew,

Oh, how I long to go.

\section{5.}

King Jesus sittin' in de kingdom, Lord,

Oh, how I long to go dere too;

De angels singin' all round de trone, Oh, how I long to go.

De trumpet sound de Jubilo,

$\mathrm{Ob}$, how I long to go dere too,

I hope dat trump will blow me home,

Oh, how $I$ long to go. 
(B), Simmer, you'd better get reary. S. $\mathrm{CHO}$.
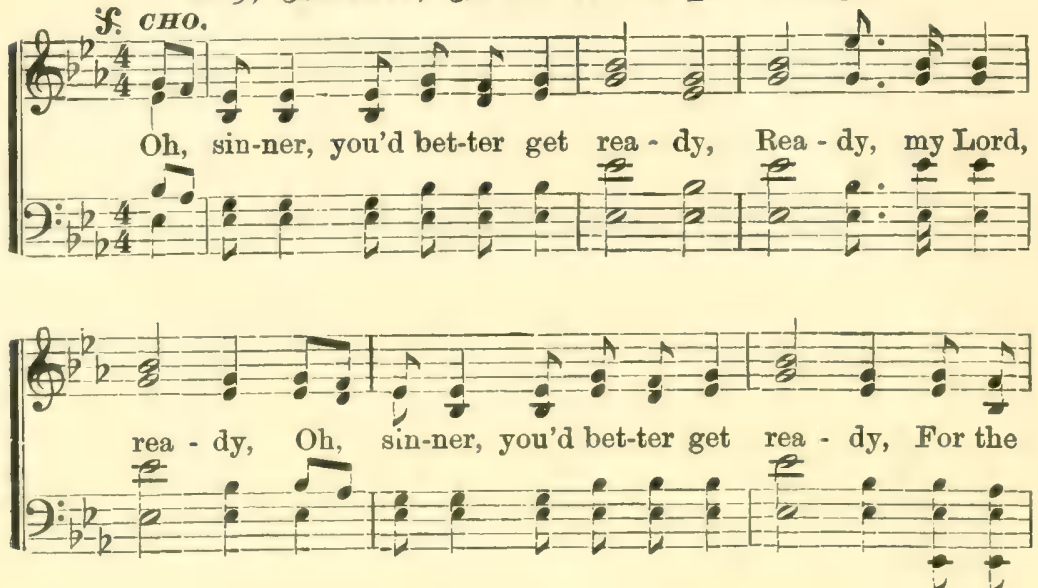

\section{FINE.ค}

$(4)^{2}-2=\therefore=a$

time is a-comin' dat sinner must die. Oh, sinner man, you had

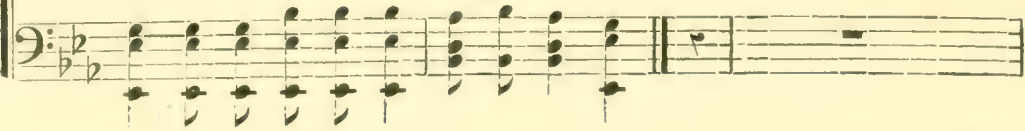

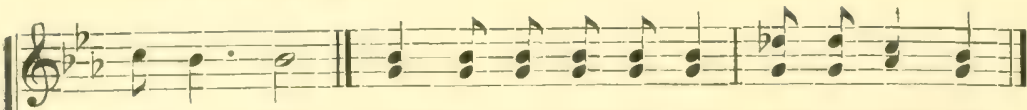
bet-ter pray, Time is a-com-in' dat sin-ner must die;

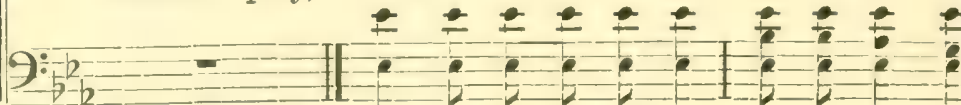

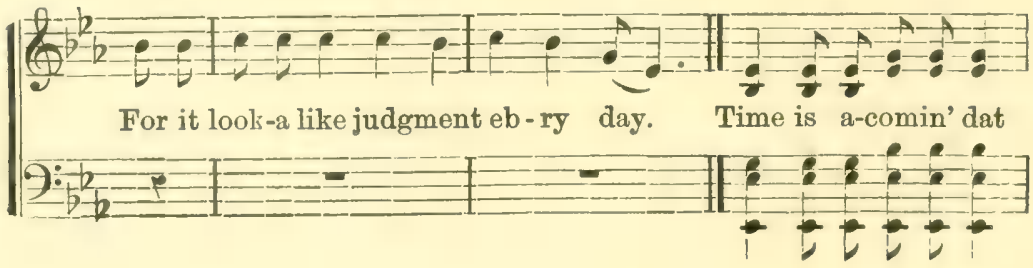


(Bb, Simner, you'd better get reayy.-Concluded.

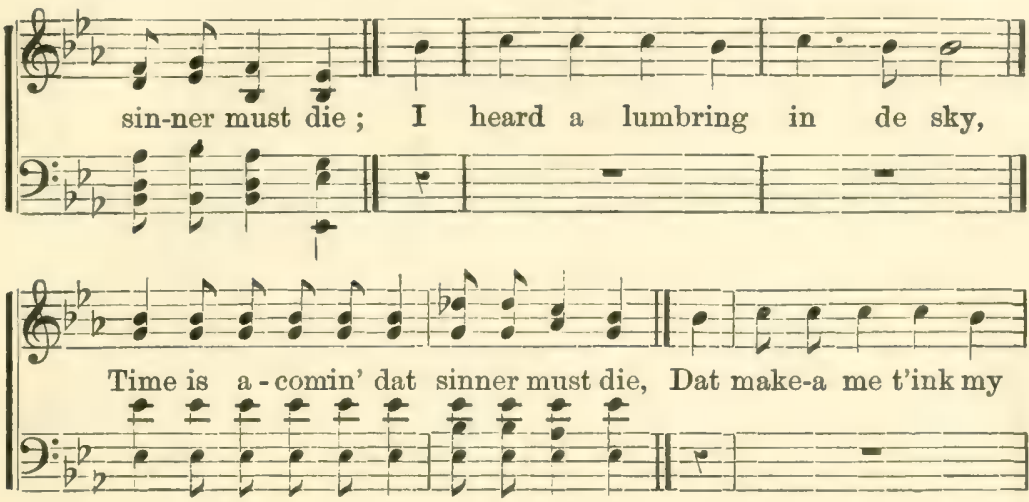

Da Capo dal Segno.

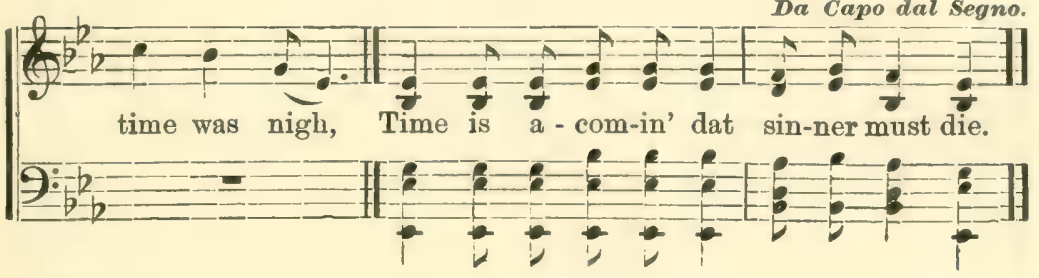

2.

I heard of my Jesus a many one say-

Time is a-comin' dat sinner must die,

Could 'move poor sinner's sins away-

Time is a-comin' dat sinner must die.

Yes, I'd rather a pray myself away-

Time is a-comin' dat sinner must die,

Dan to lie in hell an' burn a-one day-

Time is a-comin' dat sinner must die.

Cно.-Oh, sinner, you'd better get ready, \&c.

3.

I think I heard a my mother say-

Time is a-comin' dat sinner must die,

'Twas a pretty thing a to serve de Lord-

Time is a-comin' dat sinner must die.

$\mathrm{Oh}$, when I get to Heaven I'll be able for to tell_

Time is a-comin' dat sinner must die,

$\mathrm{Oh}$, how I shun dat dismal hell-

Time is a-comin' dat sinner must die.

Öо.-Oh, sinner, you'd better get ready, \&c. 


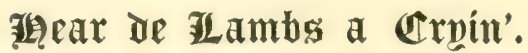

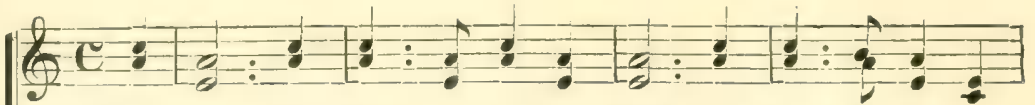

You hear de lambs a cry-in', Hear de lambs a cry-in',

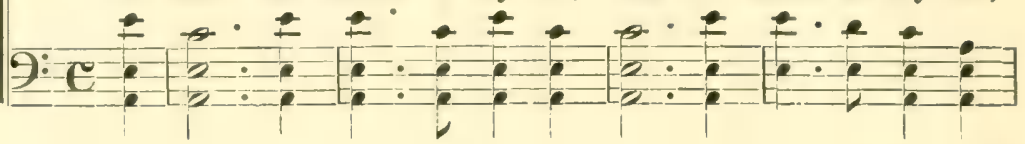

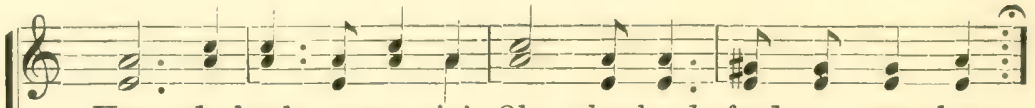
Hear de lambs a cry-in', Oh, shepherd, feed-a my sheep.

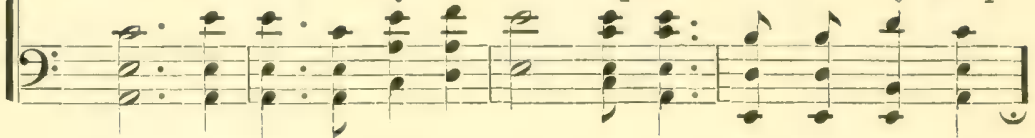
Our Sav - iour spoke dese words so sweet: "Oh shep -herd,

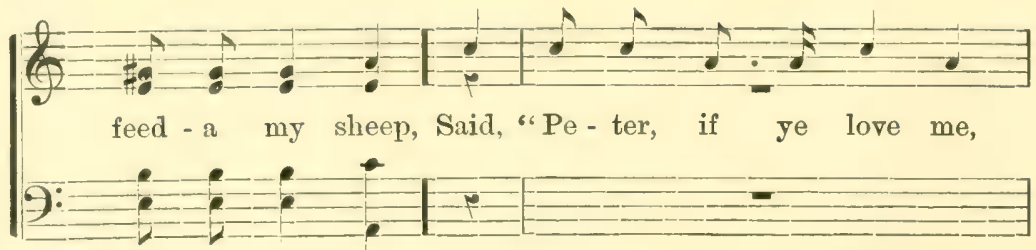

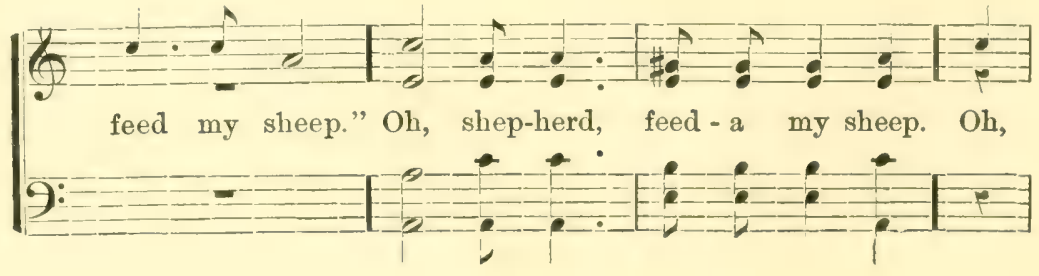




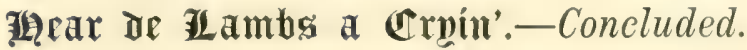
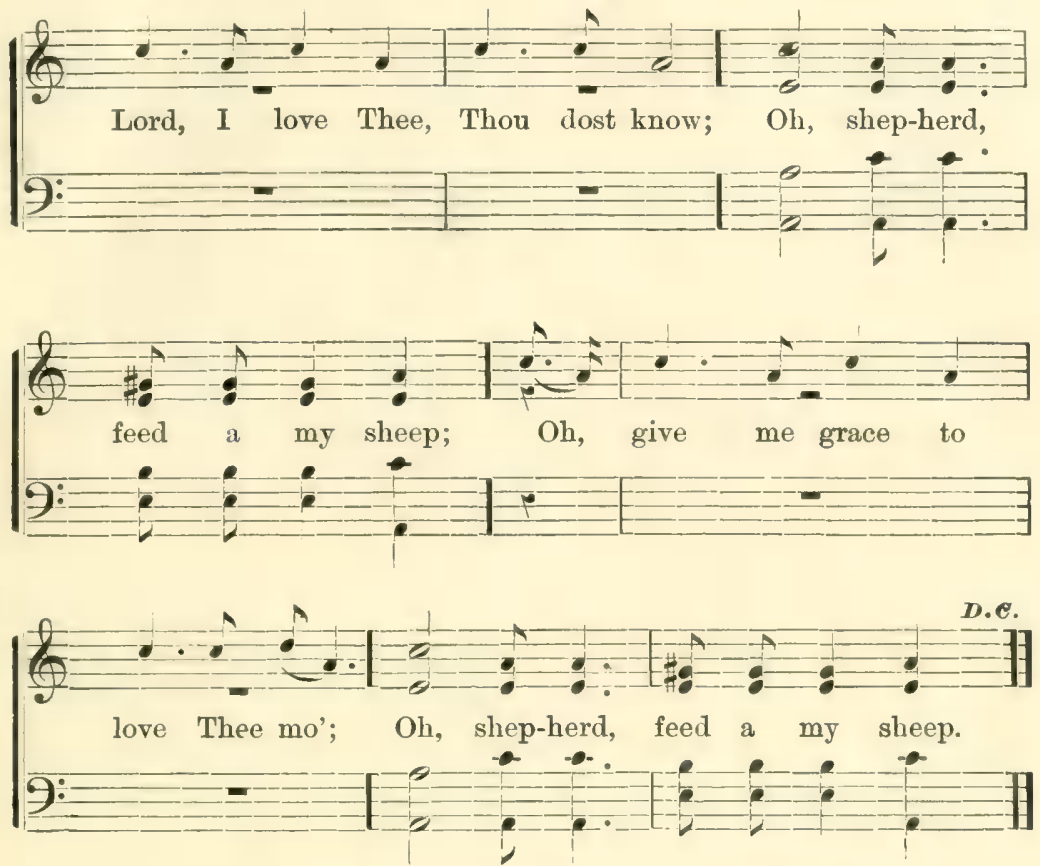

2 I don' know what you want to stay here for, Oh, shepherd, \&c., For dis vain world's no friend to grace, Oh, shepherd, \&c., If I only had wings like Noah's dove, Oh, shepherd, \&c., I'd fly away to de heavens above, Oh, shepherd, \&c.

Сно.-You hear de lambs crying, \&c.

3 When $\mathrm{I}$ am in an agony, Oh, shepherd, \&c., When you see me, pity me, Oh, shepherd, \&c., For I am a pilgrim travellin' on, Oh, shepherd, \&c., De lonesome road where Jesus gone, Oh, shepherd, \&c.

Сно.-You hear de lambs a-crying, \&c.

$4 \mathrm{Oh}$, see my Jesus hanging high, Oh, shepherd. \&c., He looked so pale an' bled so free, Oh, shepherd, \&c., Oh, don't you think it was a shame, Oh, shepherd, \&c., He hung three hours in dreadful pain, Oh, shepherd, da:

Сно.-You hear de lambs a-crying, \&c. 
CHORUS.

\section{Thise and Shine.}

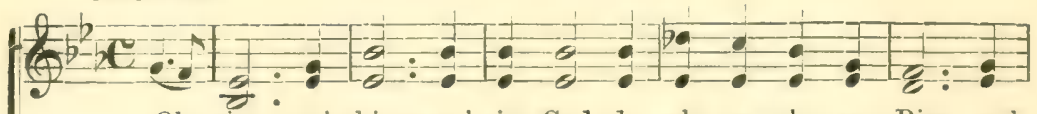

Oh, rise 'an' shine, an' give God de glo-ry, glo-ry, Rise an'

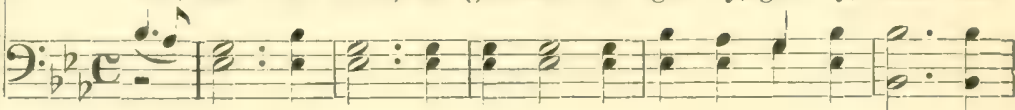

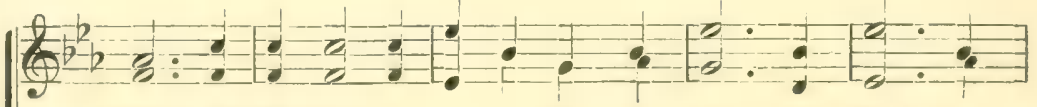

shine, an' give God de glo - ry, glo - ry, Rise an' shine, an'

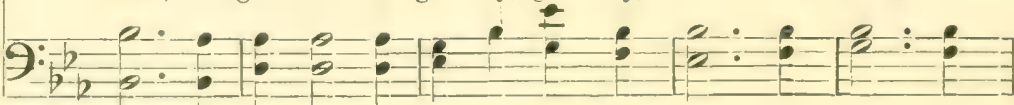
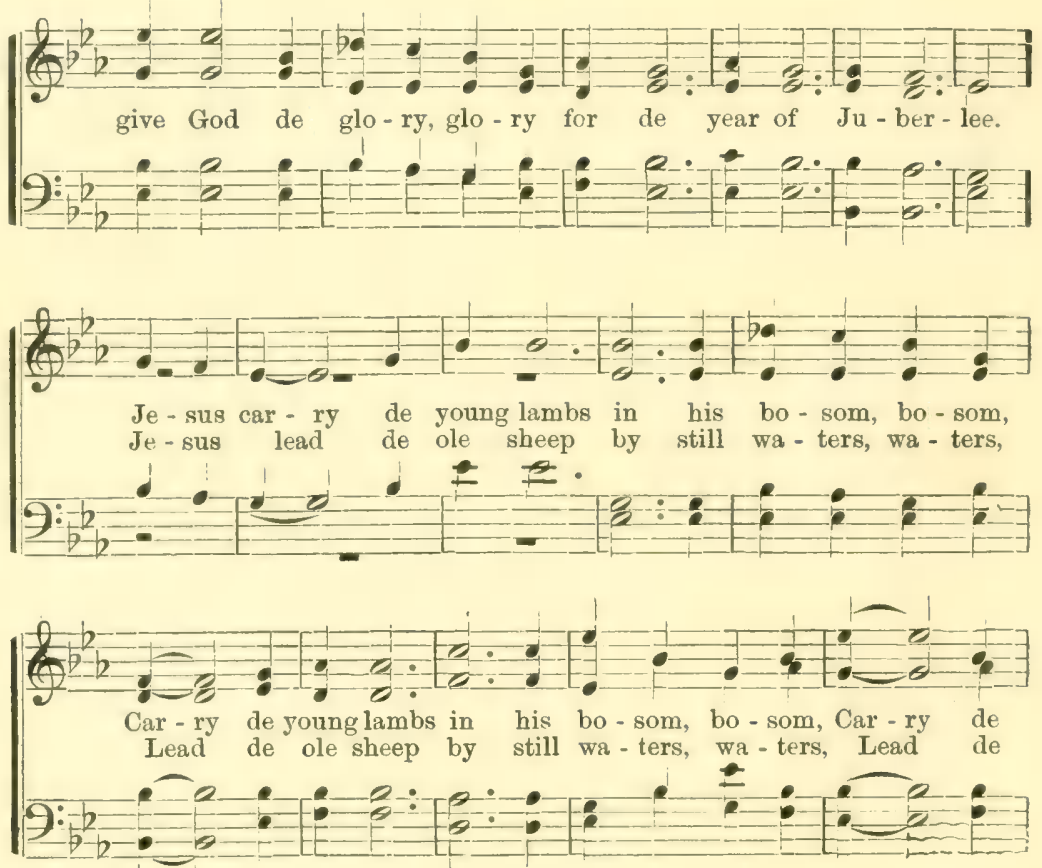


\section{Lisise and Şyitr.-Concluded.}

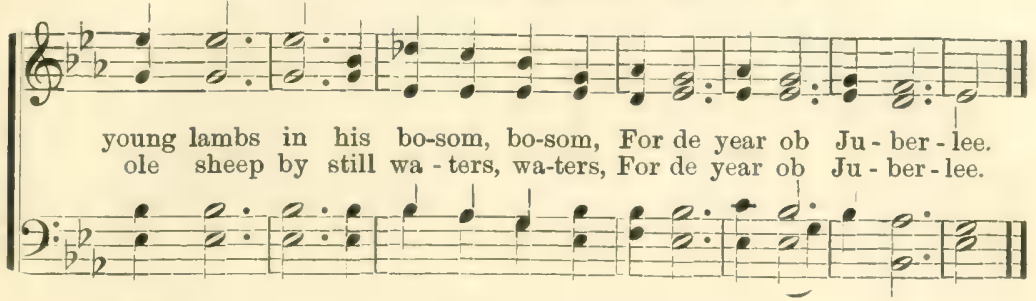

$2 \mathrm{Oh}$, come on, mourners, get you ready, ready,

Come on, mourners, get you ready, ready, (bis),

For de year ob jubilee;

You may keep your lamps trimmed an' burning, burning,

Keep your lamps trimmed an' burning, burning, (bis),

For de year ob jubilee.

Сно.-Oh, rise an' shine, \&c.

$3 \mathrm{Oh}$, come on, children, don't be weary, weary,

Come on, children, don't be weary, weary, (bis),

For de year ob jubilee;

$\mathrm{Oh}$, don't you hear dem bells a-ringin', ringin',

Don't you hear dem bells a-ringin', ringin', (bis),

For de year ob jubilee.

CHo.-Oh, rise an' shine, \&c.

\section{7lgard Trials.}
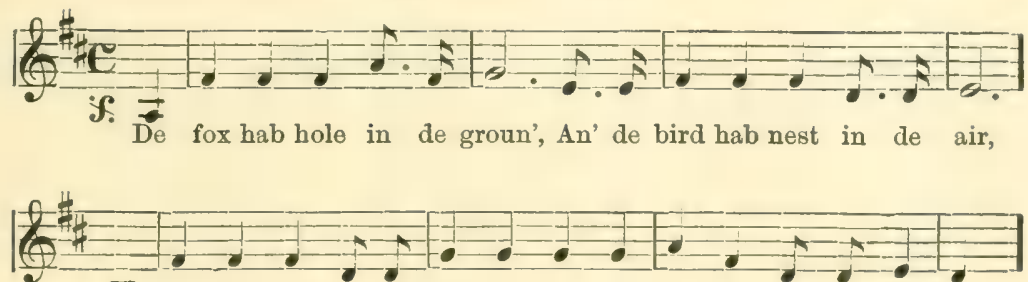

An' eb - ry t'ing hab a hid - ing-place, But we, poor sin-ner, hab rone.

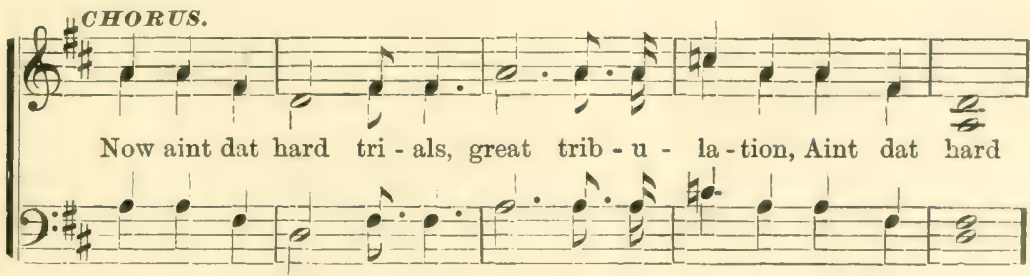




\section{zglard Trials.-Concluded.}

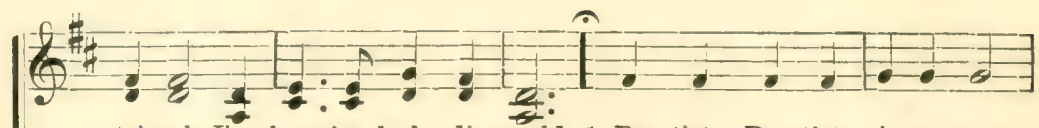

tri - als I'm boun' to leabe dis world. 1. Bap-tist, Bap-tist is my name, 2. Methodist, Methodist is my name, 3. Presbyterian, Presbyterian, \&c.
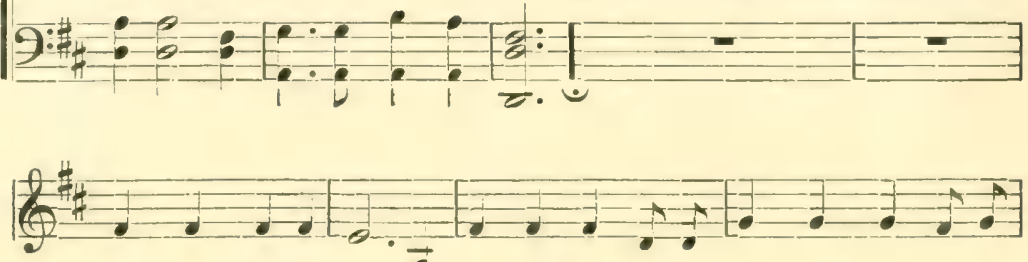

Bap - tist till I die, I'll be baptize in de Bap - tist name, An' I'll

Metho-dist till I die, I'll be baptize in de Methodist name, An' I'll Presbyterian till, \&c.

D.S. Cho, al Fine.

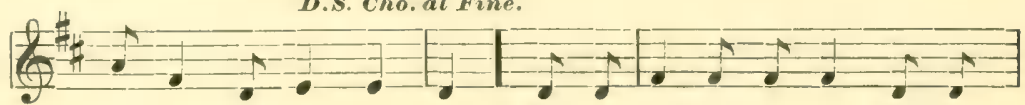

lib on de Bap - tist side. 4. You may go dis - a way, You may,

lib on de Methodist side.

lib on de Presbyterian side.
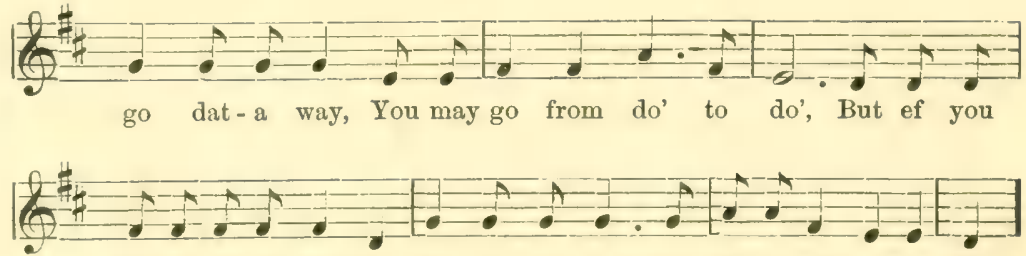

hab-n't got de grace ob God in you heart, De deb-il will get you sho'.

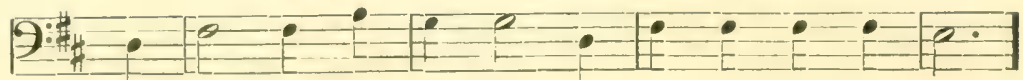

5. Now while we are march-in a - long dis dread-ful road,

D.C. dal Cho.

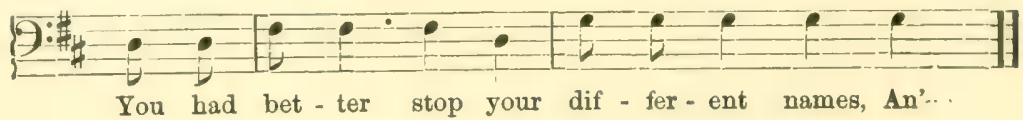




\section{fthost 眲one Trabelling.}
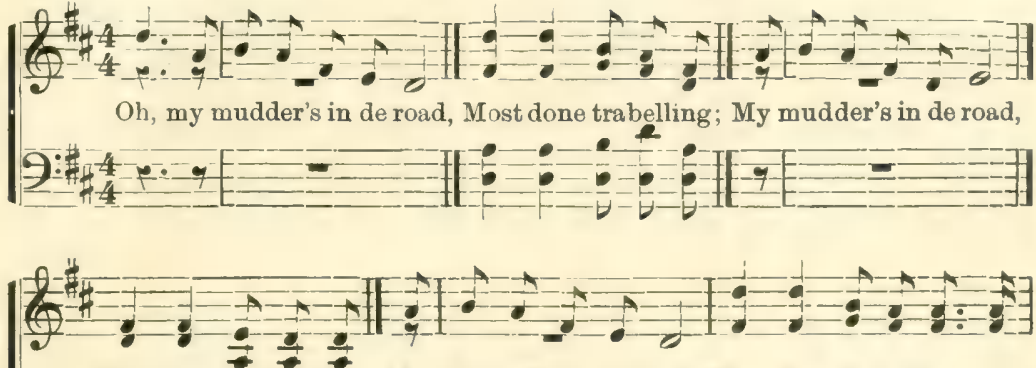

Most done tra-bel-ling, My mudder's in de road, Most done trabelling. I'm
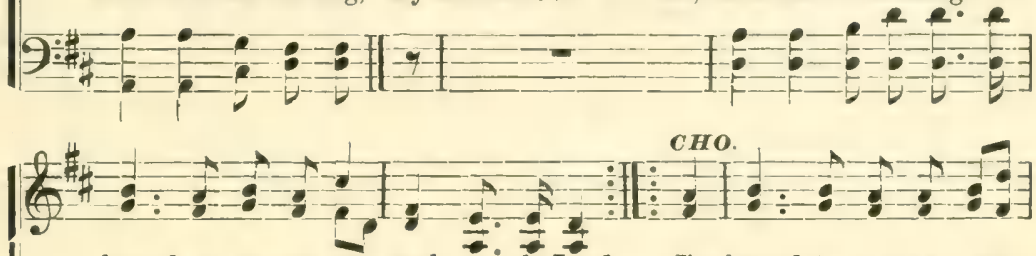

bound to car-ry my soul to de Lord. I'm bound to car-ry my
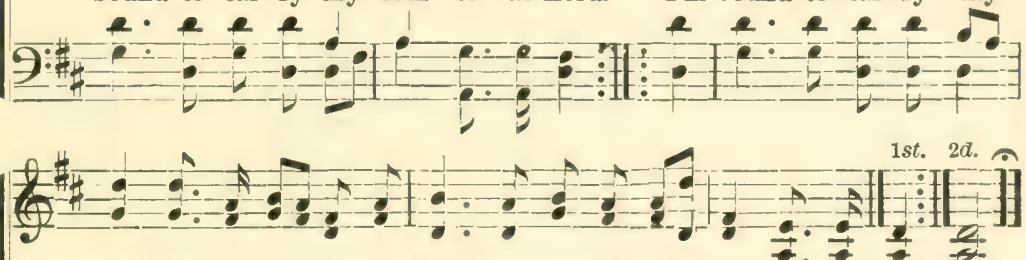

soul to my Je-sus, I'm bound to car-ry my soul to de Lord; Lord.

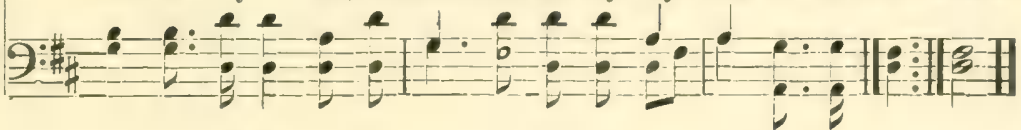

2.

Oh, my sister's in de road,

Most done trabelling,

My sister's in de road,

Most done trabelling. (bis)

Cно.-I'm bound to carry, \&c.

3.

$\mathrm{Ob}$, my brudder's in de road,

Most done trabelling,

My brudder's in de road, \} (bis)

Most done trabelling. $\int_{\text {- I'm bound to carry, }}$ \&c.
4.

$\mathrm{Oh}$, de preacher's in de road, Most done trabelling,

De preacher's in de road, $\}$ (bis)

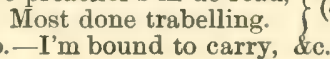

\section{5.}

All de member's in de road, Most done trabelling,

De members' in de road, $\}$ (bis)

Most done trabelling.
-I'm bound to carry, \&c. 
СНо.

\section{Grwine up.}

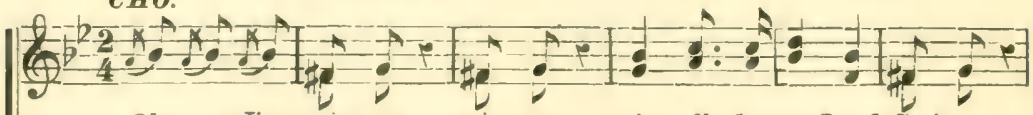

Ob, yes, I'm gwine up, gwine up, gwine all de way, Lord, Gwine up,
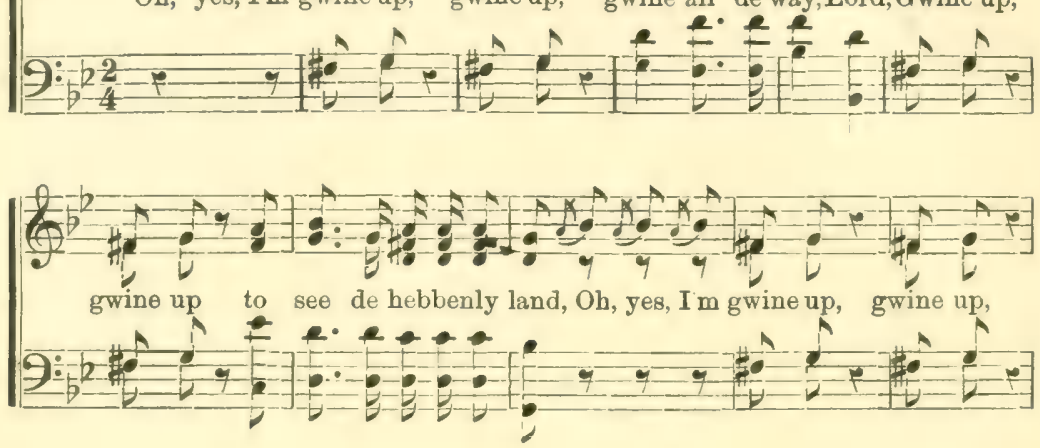

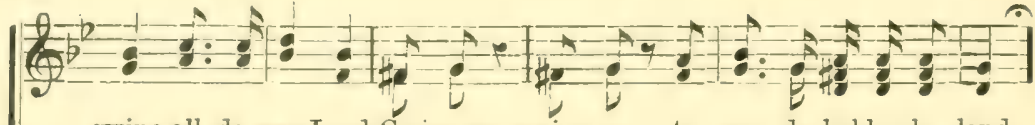
gwine all de way, Lord, Gwine up, gwine up to see de hebbenly land.

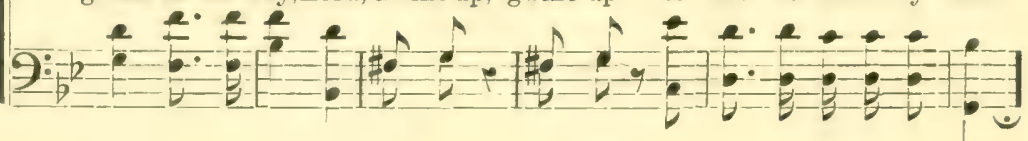

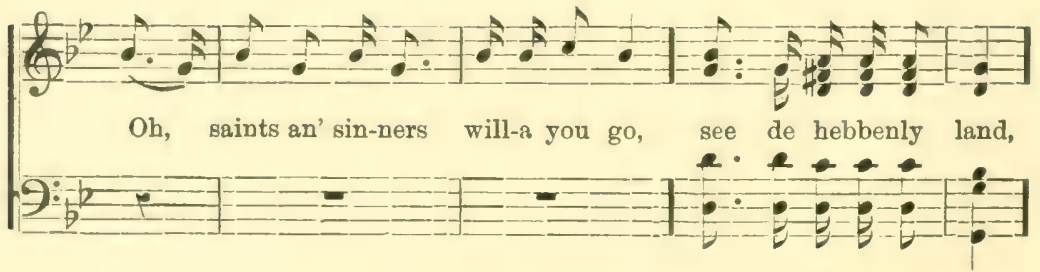

$(4)^{2}-A-A B$

I'm a gwine up to heaven for to see my robe, See de hebbenly lund,

$\begin{array}{ll}9:-b-F=E & =\end{array}$ 
Gmine up.-Concluded.
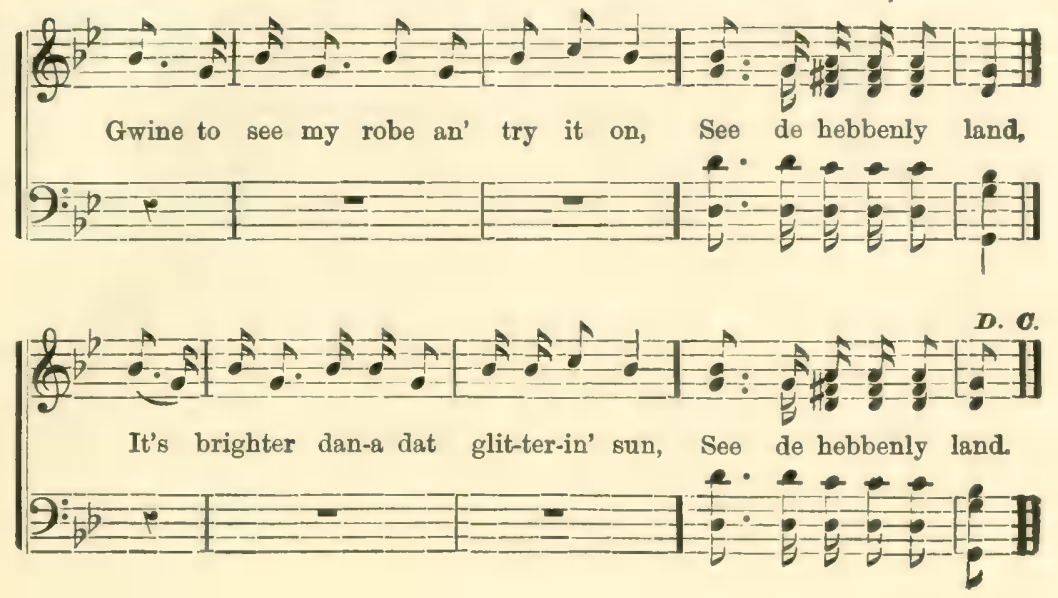

2.

I'm a gwine to keep a climbin' high-

See de hebbenly land;

Till I meet dem-er angels in-a de sky-

See de hebbenly lan'.

Dem pooty angels I shall see-

See de hebbenly lan';

Why don't de debbil let-a me be-

See de hebbenly lan'.

Сно.-Oh yes, I'm gwine up, \&c.

3.

I tell you what I like-a de best-

See de hebbenly lan';

It is dem-a shoutin' Methodess-

See de hebbenly lan';

We shout so loud de debbil look-

See de hebbenly lan';

An' he gets away wid his cluvven foot-

See de hebbenly lan'.

Сно.-Oh, yes, I'm gwine up, 


\section{3) bope my ftlotber will be there.}

This was sung by the hands in Mayo's Tobacco Factory, Richmond, and is really called "The Mayo Boys' Song."

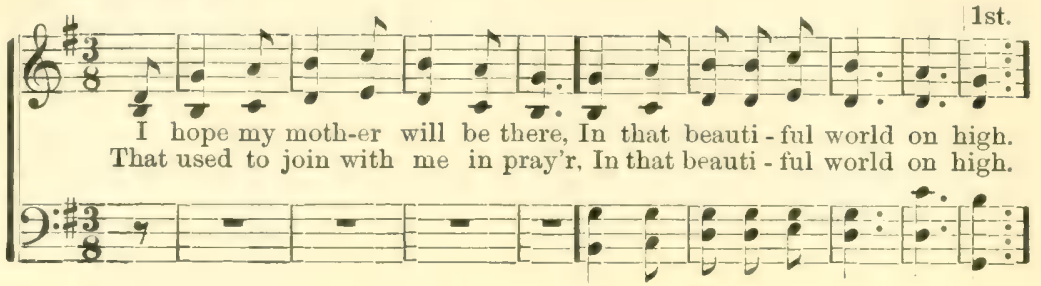

2d. CHO.

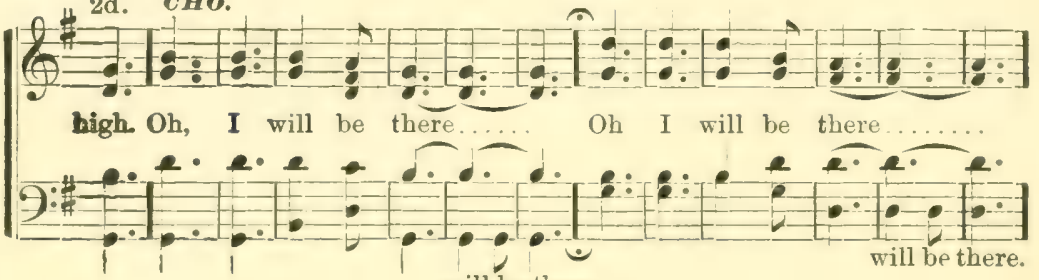

will be there,
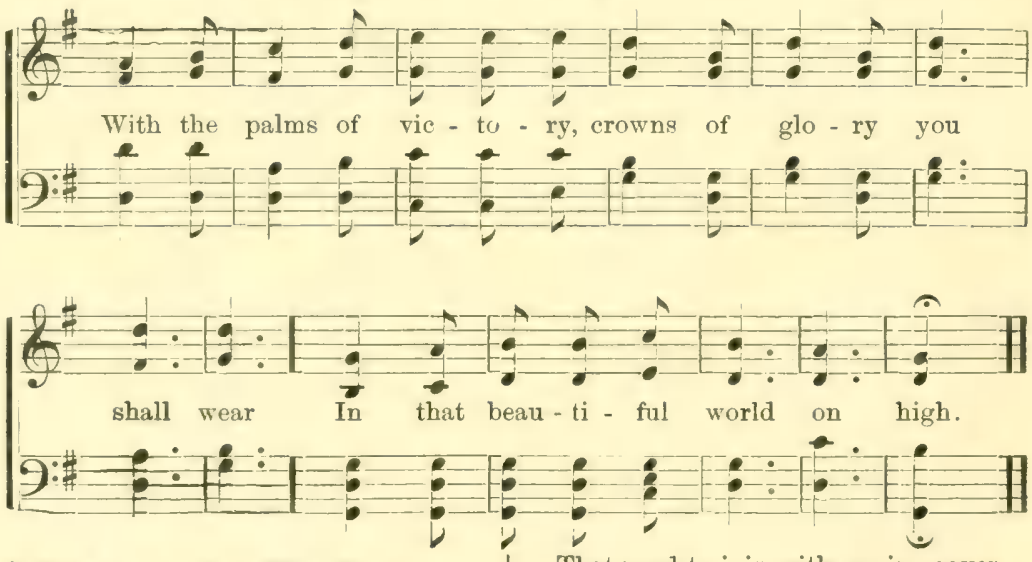

2 I hope my stster will be there.

In that beautiful world on hign.

That used to join with me in prayer,

In that beautiful world on high.

Crо.-Oh, I will be there. \&c.

3 I hope my brother will be there,

In that baautiful world on high.

That used to join with me in prayer,

In that beautiful world on high.

Cно.-Oh, I will be there, \&c.

4 I know my Saviour will be there,

In that ueautiful world on high,

That used to listen to my prayer,

In that beantiful world on high.
Cвo.-Oh, I will be there, \&c. 


\section{Ob, Ine 7gebben is Stuinin'.}

CHORUS.

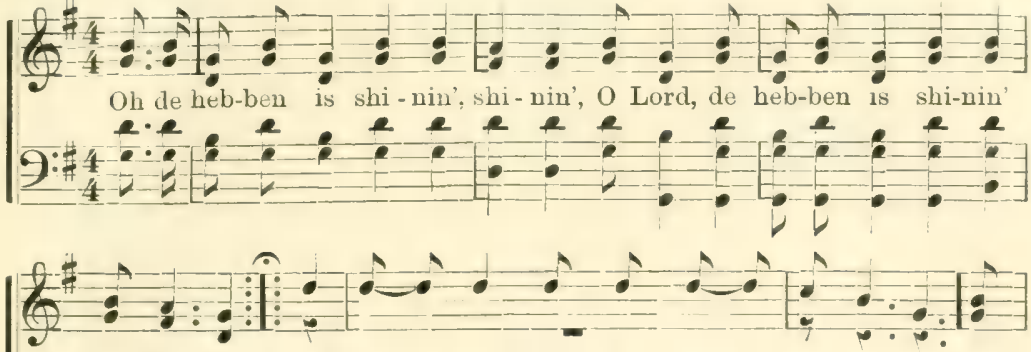

full ob love. Oh, Fare-you-well, friends, I'm gwine to tell vou all; De $\mathrm{Ob}$, when I build a my tent a - gin', De
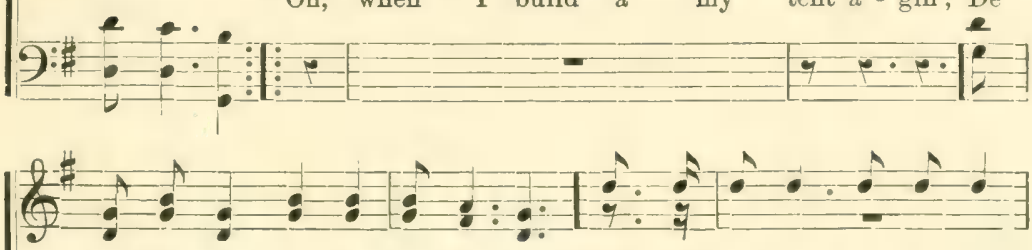

heb-ben is shi-nin' full ob love; Gwine to leave you all a - mine beb-ben is shi-uin' full ob love; Build it so ole $\mathrm{Sa}$ - tan he
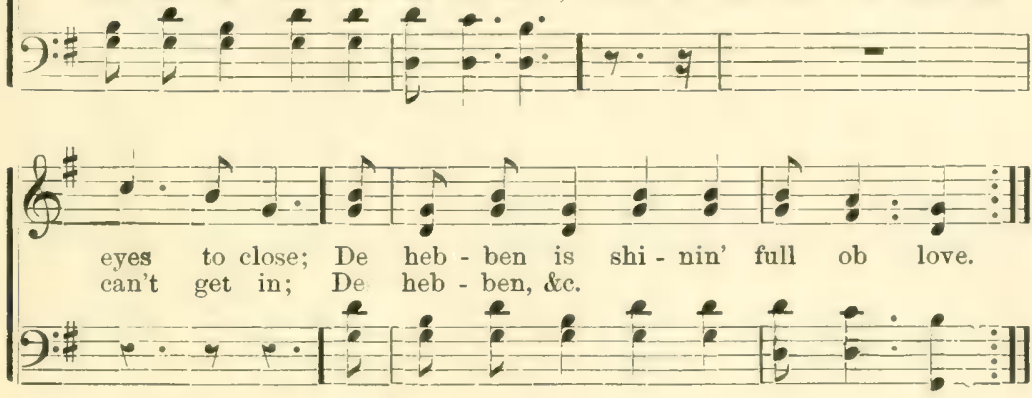

2 Death say, "I come on a-dat hebbenly 'cree; De hebben is, \&c. My warrant's for to summage thee; De hebben is, \&c. An' whedder thon prepared or no; De hebben is, \&c.

Dis very day He say you must go;" De hebben is, \&c. - Cho.

3 Oh, ghastly Doath, wouldst thou prevail; De hebben is, \&c. $\mathrm{Ob}$, spare me yet anoder day; De hebben is, \&e.

I'm but a flower in my bloom; De hebben is, \&c.

Why wilt thou cut-a me down so soon? De hebben is, \&c.-.Cho.

$4 \mathrm{Oh}$, if I had-a my time agin; De hebben is, \&c.

I would hate dat road-a dat leads to sin; De hebben is, \&c.

An' to my God a-wid earnest pray; De hebben is, \&c.

An' wrastle until de break o' day; De hebben is, \&c.-Cho. 


\section{xeaboll jine de Anion.}
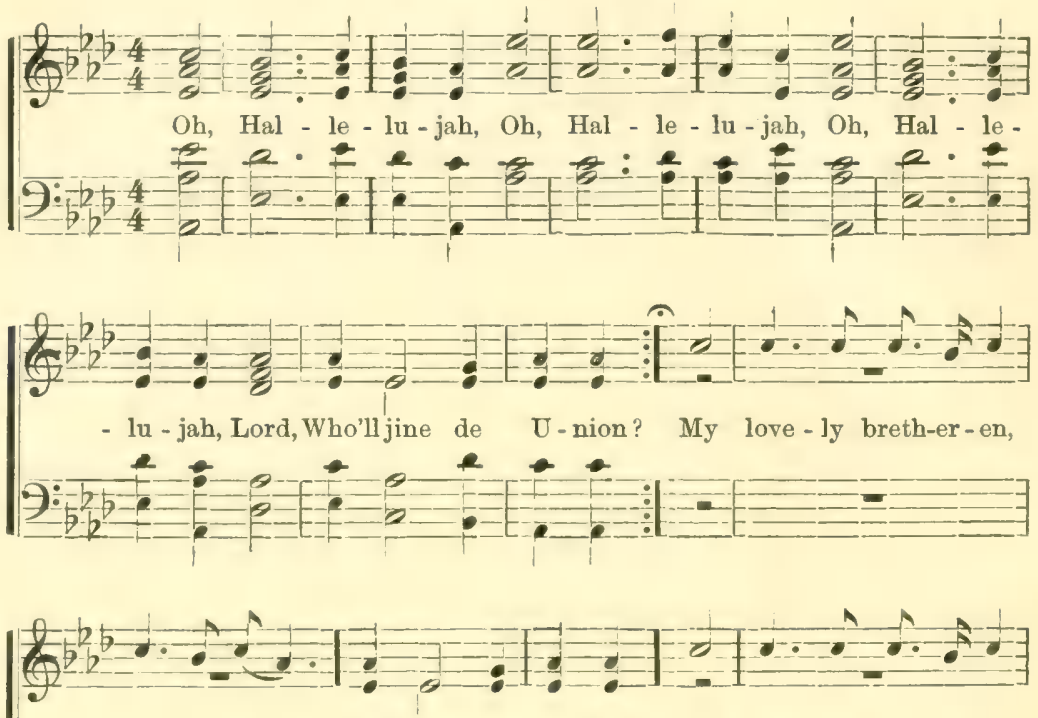

how ye do? Who'll jine de U-nion? Oh, does yer love a-con-

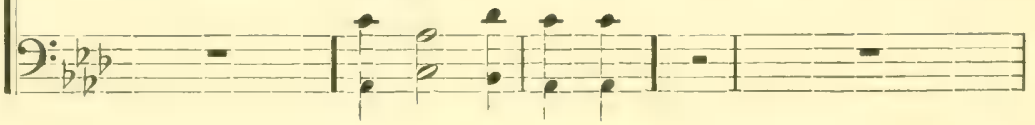
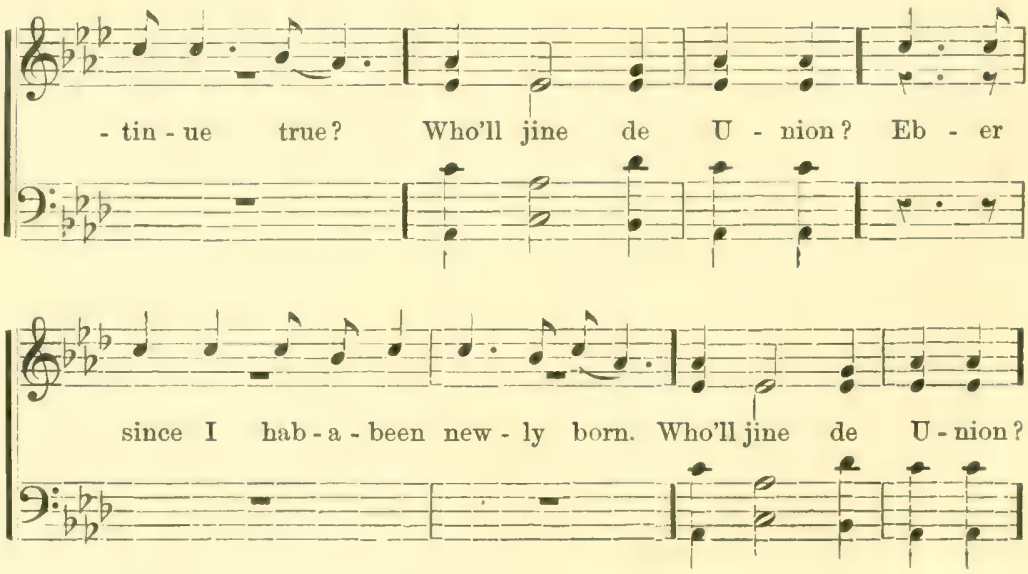


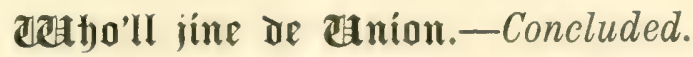

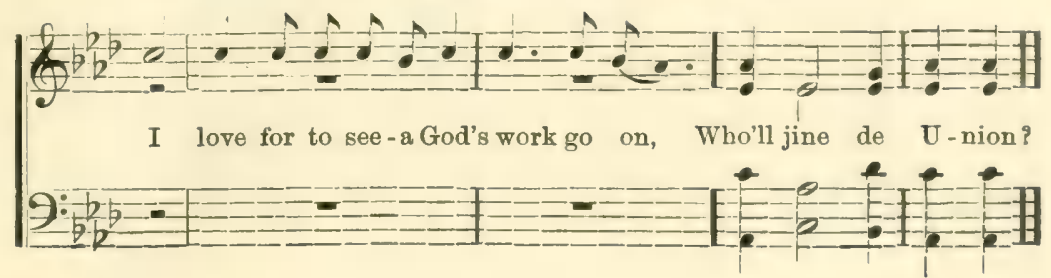

2.

Ef ye want to ketch-a dat hebbenly breeze.

Who'll jine de Union?

Go down in de valley upon yer knees,

Who'll jine de Union?

Go bend yer knees right smoove wid de groun?

Who'll jine de Union?

An' pray to de Lord to turn you roun',

Who'll jine de Union?

Cно.-Oh, Hallelujah, \&c.

4.

Say, ef you belong to de Union ban',

Who'll jine de Union?

Den here's my heart, an' here's my han'

Who'll jine de Union?

I love yer all, both bond an' free,

Who'll jine de Union?

I love you ef-a you don't love me,

Who'll jine de Union?

Cво.-Oh, Hallelujah, \&c.

3.

Now ef you want to know ob me,

Who'll jine de Union?

Jess who I am, an' a-who I be,

Who'll jine de Union?

I'm a chile ob God, wid my soul sot free,

Who'll jine de Union?

For Christ hab bought my liberty,

Who'll jine de Union?

Cuo.-Oh, Hallelujah, \&c. 


\section{A great $\mathbb{C}$ amp=mertin' in de Aromised zland.}

"This hymn was made by a company of Slaves, who were not allowed to sing or pray anywhere the old master could hear them; and when he died their old mistress looked on them with pity, snd granted them the privilege of singing and praying in the cabins at night. Then they sang this hymn, and shouted for joy, and gave God the honor and praise."

J. B. TowE.

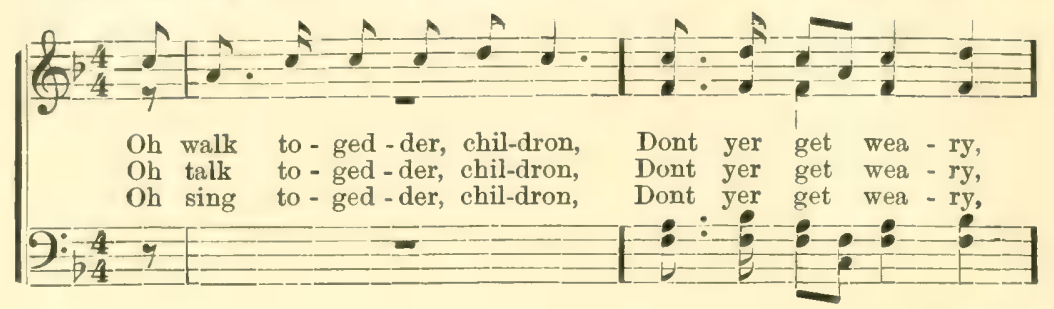

$\mathrm{Oh}$
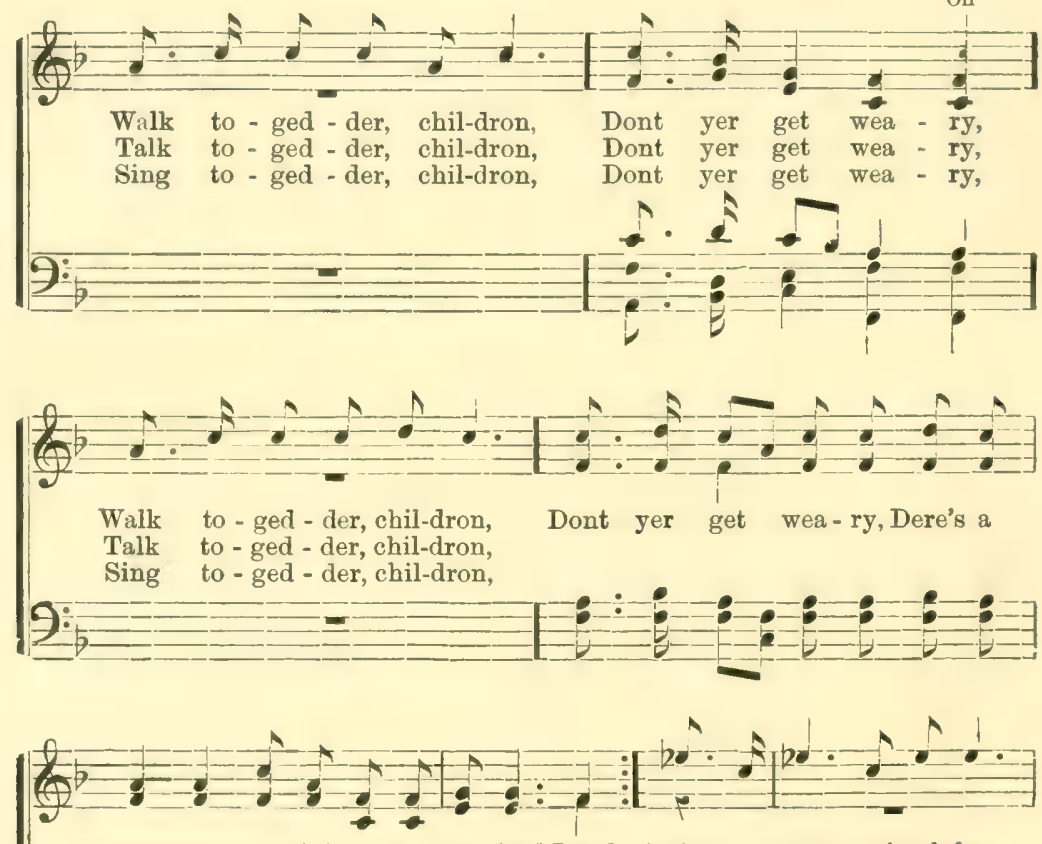

great camp-meetin' in de Promised Land. Gwine to mourn an' neb-ber

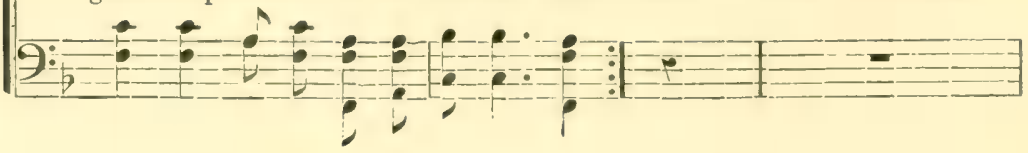



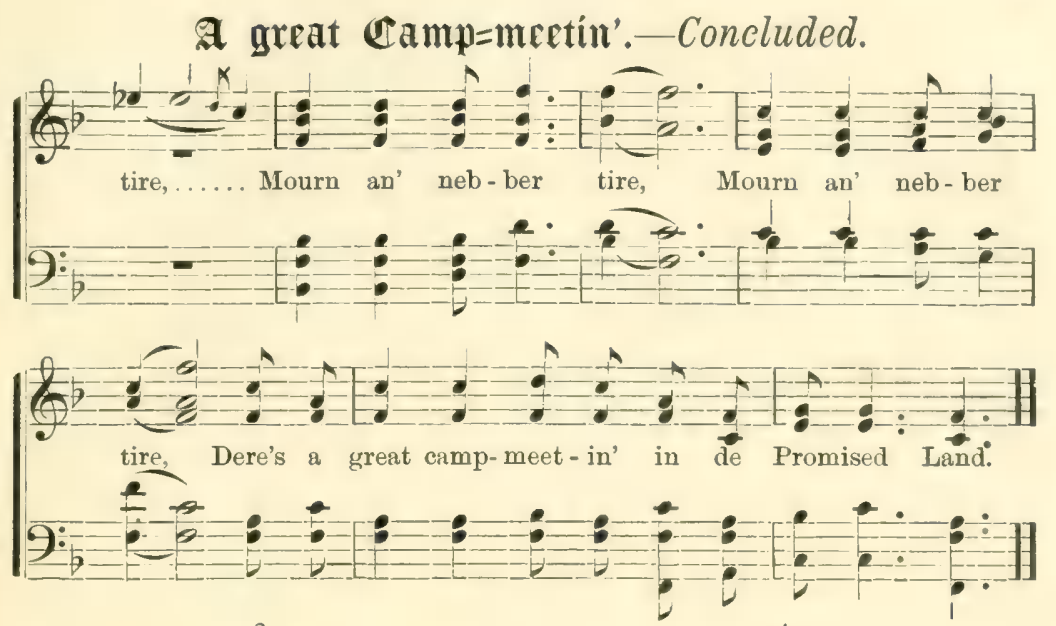

2.

Oh get you ready, childron, Dont you get weary,

Get you ready, childron, Dont you, \&c. (bis. Dere's a great camp-meetin' in de Prom. ised Land.

For Jesus is a comin', Dont you get, \&c, Jesus is a comin', Dont you get, \&c., (bis. Dere's a great camp-meetin' in de Promised Land.

Gwine to hab a happy meetin', Dont you get weary,

Hab a happy meetin', Dont you get, \&c. (bis.

Dere's a great camp-meetin' in de Promised Land.

Cво.-Gwine to pray an' nebber tire,

Pray an' nebber tire, (bis.)

Dere's a great camp-meetin' in de Promised Land.

3.

Gwine to hab it in hebben, Dont you, \&c. Gwine to hab it in hebben, Dont, \&c. (bis. Dere's a great camp-meetin' in de, \&c.,

Gwine to shout in hebben, Dont you get weary,

Shout in hebben, Dont you get, \&c., (bis.

Dere's a great camp-meetin' in de, \&c.,

Oh will you go wid me, Dont you get, \&c.,

Will you go wid me, Dont you get, \&c., (bis.

Dere's a great camp-meetin' in de, \&c.,

Сво.-Gwine to shout an' nebber tire,

Shout an' nebber tire, (bis.)

Dere's a great camp-meetin' in de Promised Land,
Dere's a better day comin', Dont you get weary,

Better day a comin', Dont you get, \&c., (bis. Dere's a great camp-meetin' in de Promised Land.

Oh slap your hands childron, Dont, \&c. Slap your hands childron, Dont, \&c., (bis.

Dere's a great camp-meetin' in de Promised Land.

Oh pat your foot childron, Dont you get weary,

Pat your foot childron, Dont, \&e., (bis.)

Dere's a great camp-meetin' in de Promised Land.

CHo.-Gwine to live wid God forever,

Live wid God forever, (bis.)

Dere's a great camp-meetin' in de Promised Land.

$$
5 .
$$

Oh, feel de Spirit a movin', Dont you, \&c.

Feel de Spirit a movin', Dont, \&c., (bis.)

Dere's a great camp-meetin' in de, \&c.

Oh now I'm gettin' happy, Dont you get weary,

Now I'm gettin' happy, Dont, \&c., (bis.)

Dere's a great camp-meetin' in de, \&c.

I feel so happy, Dont you get weary,

Feel so happy, Dont you get weary, (bis.)

Dere's a great camp-meetin' in de, \&c.

Cно.-O Oh, fly an' nebber tire,

Fly an' nebber tire, (bis.)

Dere's a great camp-meetin' in de Promised Land. 


\section{Good news, de cijariot's comin'.}

CHORUS.

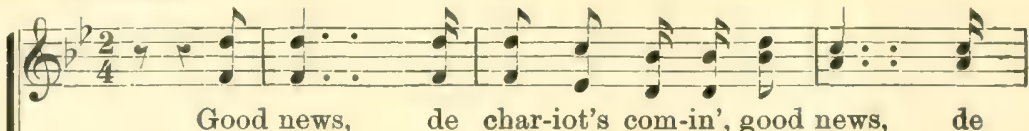
Good news
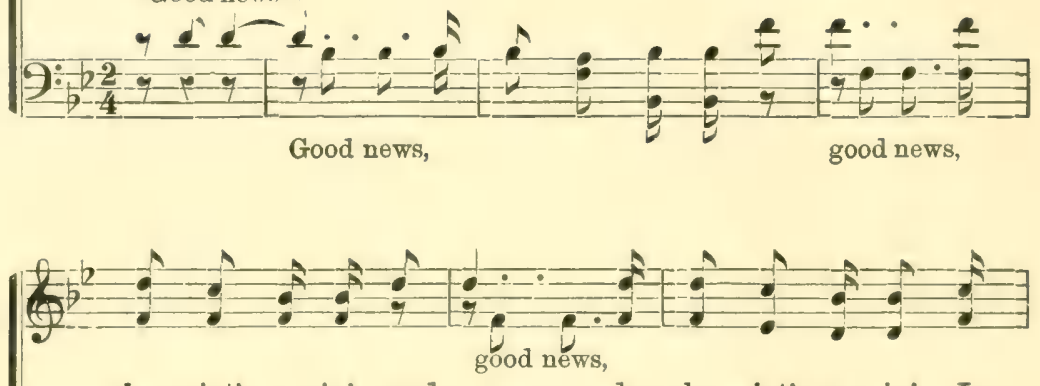

cha-riot's comin', good news, de cha-riot's com-in', I
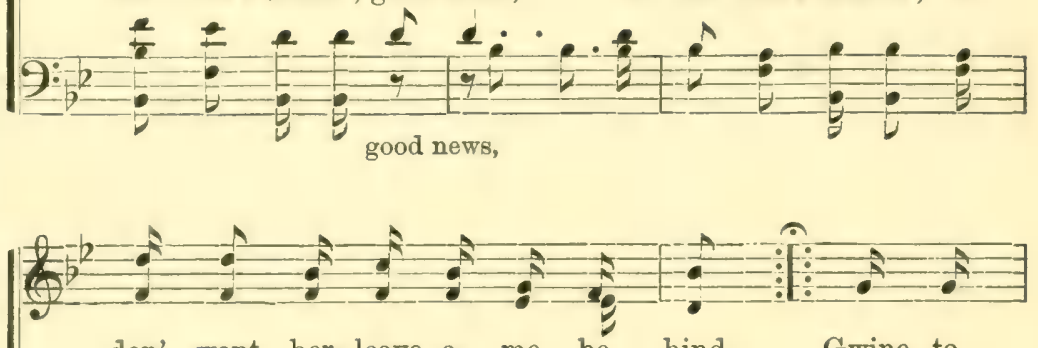

don' want her leave a me be - hind. Gwine to
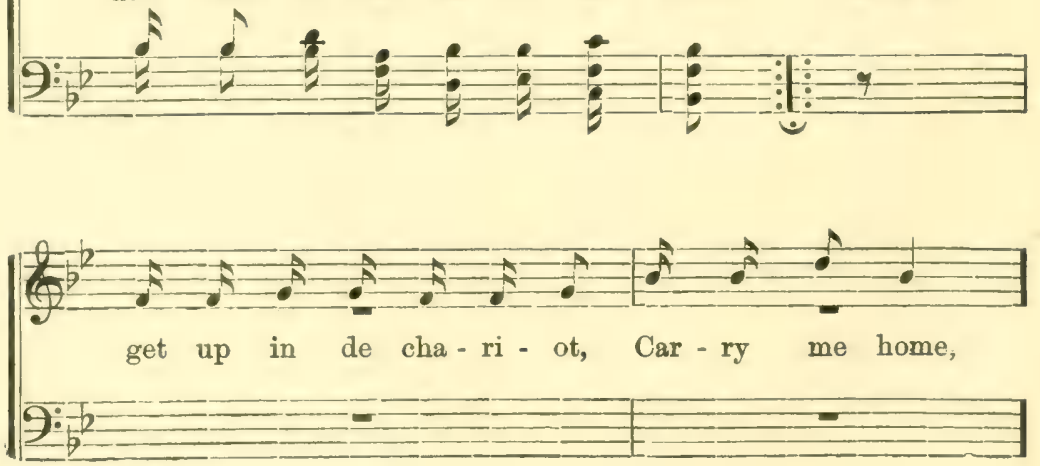
Good news, de C'bariot's comin'.-Concluded.
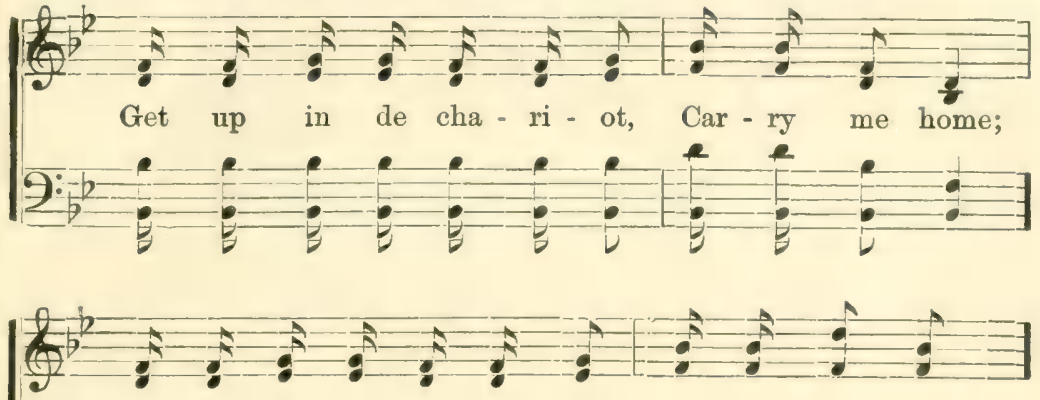

Get up in de cba-ri - ot, car - ry me home,
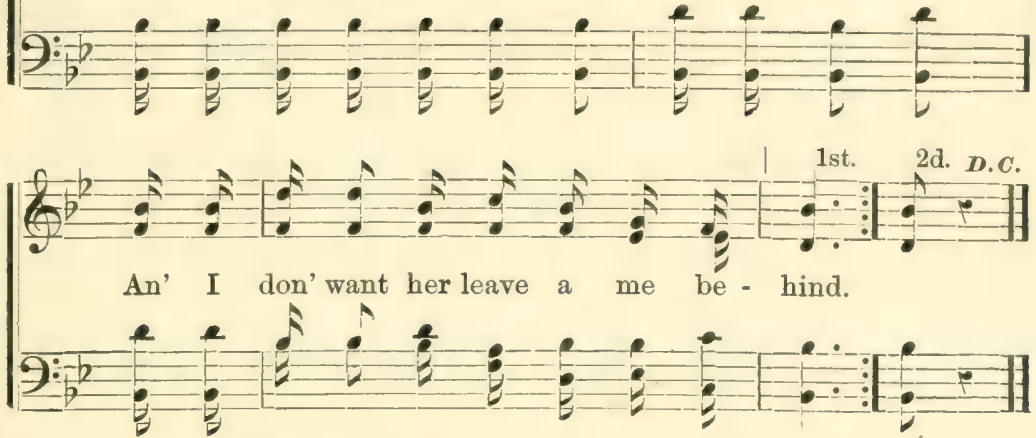

2 Dar's a long white robe in de hebben I know,

A long white robe in de hebben, I know,

A long white robe in de hebben, I know, An'I don' want her leave-a me behind.

Dar's a golden crown in de hebben, I know,

A golden crown in de hebben, I know,

A golden crown in de hebben, I know, An' I don' want her leave-a me behind.

Сно.-Good news, de chariot's comin', \&c.

3 Dar's a golden harp in de hebben, I know, A golden harp in de hebben, I know, A golden harp in de hebben, I know, An' I don' want her leave-a me behind.

Dar's silver slippers in de hebben, I know, Silver slippers in de hebben, I know, Silver slippers in de hebben, I know, An' I don' want her leave-a me behind.

Cво.-Good news, de chariot's comin', \&c. 
Jon't pe biew rat ship a come a sailin'.
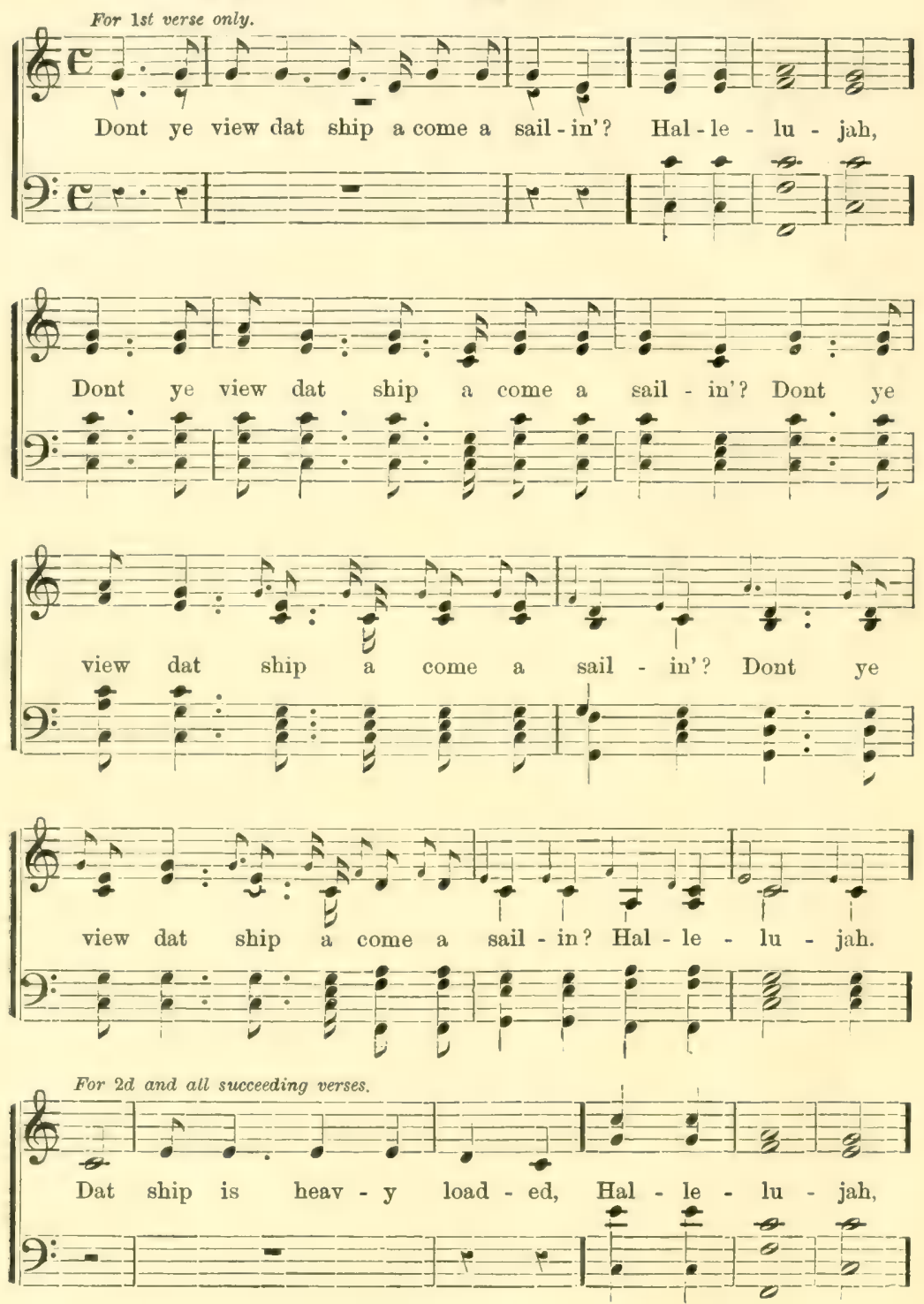


\section{J78nt pe bíew dat ship.-Concluded.}
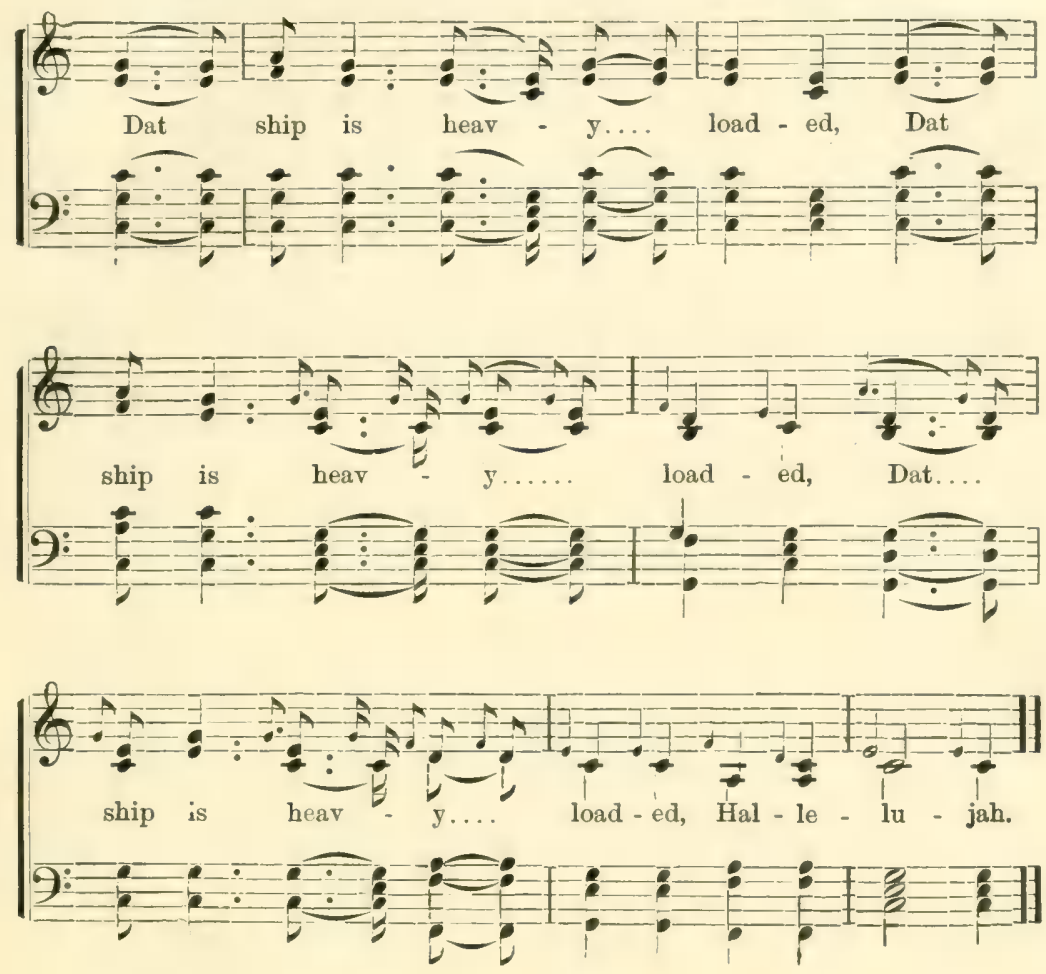

2 Dat ship is hervy loaded, Hallelujah, \&c.

3 She neither reels nor totters, Hallelujah.

4 She is loaded wid-a bright angels, Hallelujah.

$5 \mathrm{Oh}$, how do you know dey are angels? Hallelujah.

6 I know dem by a de'r mournin', Hallelujah.

$7 \mathrm{Oh}$, yonder comes my Jesus, Hallelujah.

$8 \mathrm{Oh}$, how do you know it is Jesus? Hallelujah.

9 I know him by-a his shinin', Hallelujah. 


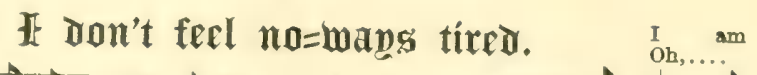

$\mathrm{Oh}$,

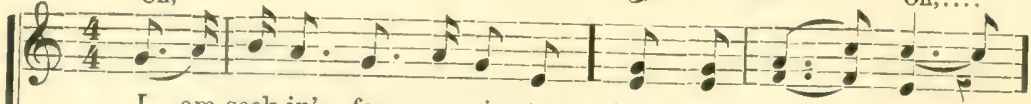

I am seek-in' for a ci - ty, Hal - le - lu - jah,

Ob,... bredren, trab - bel wid me, Hal - le - lu - jah,

$9 \div 4=+21=01$

For a

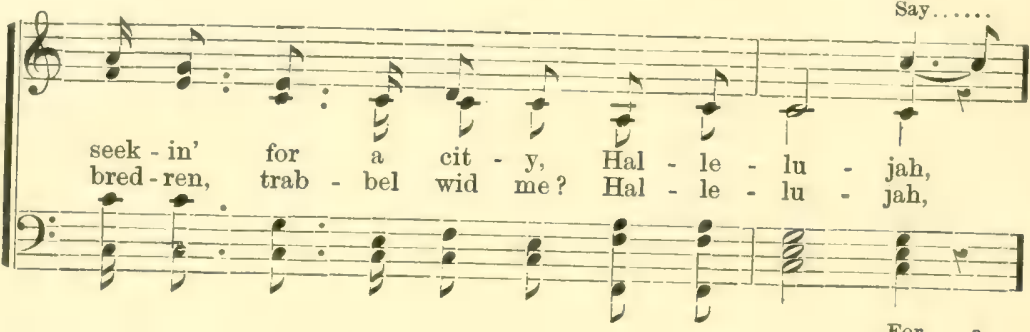

For a

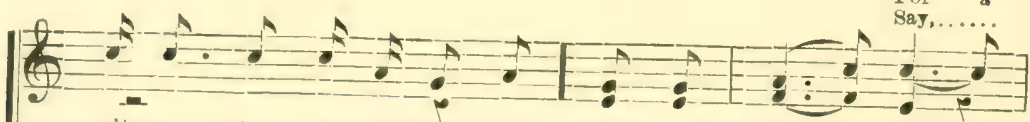

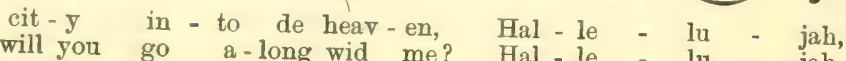

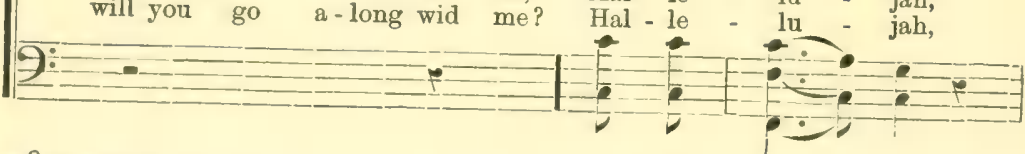

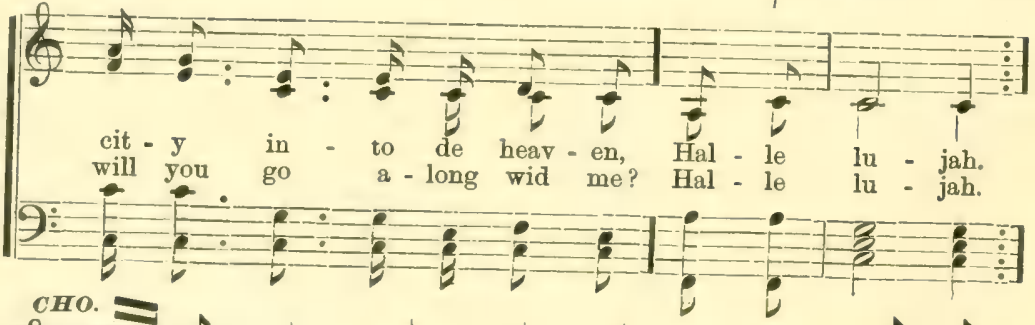

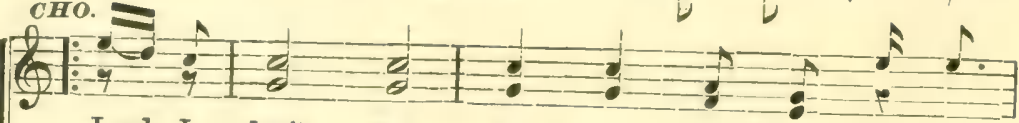

Lord, I don't feel no - ways ti - red, Chil-dren,

$9: 7: y=\frac{2}{7}=1=$ 
If Don't feel no=mans tíred.-Concluded.
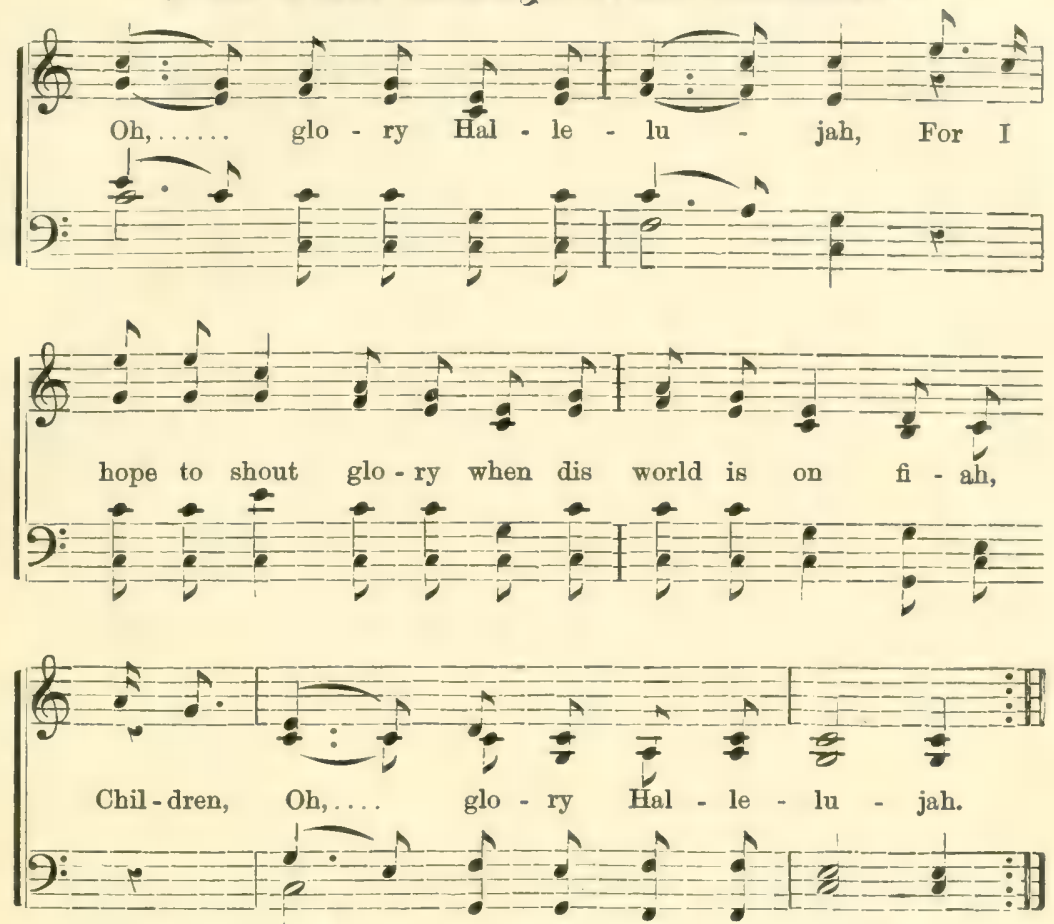

2 We will trabbel on together, Hallelujah, Gwine to war agin de debbel, Hallelujah,

Gwine to pull down Satan's kıngdom, Hallelujah, " Gwine to build up de walls o' Zion, Hallelujah.

Cно.-Lord, I don't feel no-ways tired, \&c.

3 Dere is a better day a comin', Hallelujah, (bis)

When I leave dis world o' sorrer, Hallelujah, For to jine de holy number, Hallelujab, Den we'll talk de trouble ober. Hallelujah.

Сно.-Lord, I don't feel no-ways tired, \&c.

4 Gwine to walk about in Zion, Hallelujah, (bis)

Gwine to talk n wid de angels, Hallelujah,

Gwine to tell God 'bout my crosses, Hallelujah, " Gwine to reign wid Him foreber, Hallelujah.

Сно. - Lord, I don't feel no-ways tired, \&c. 


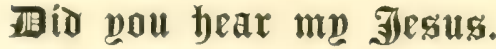
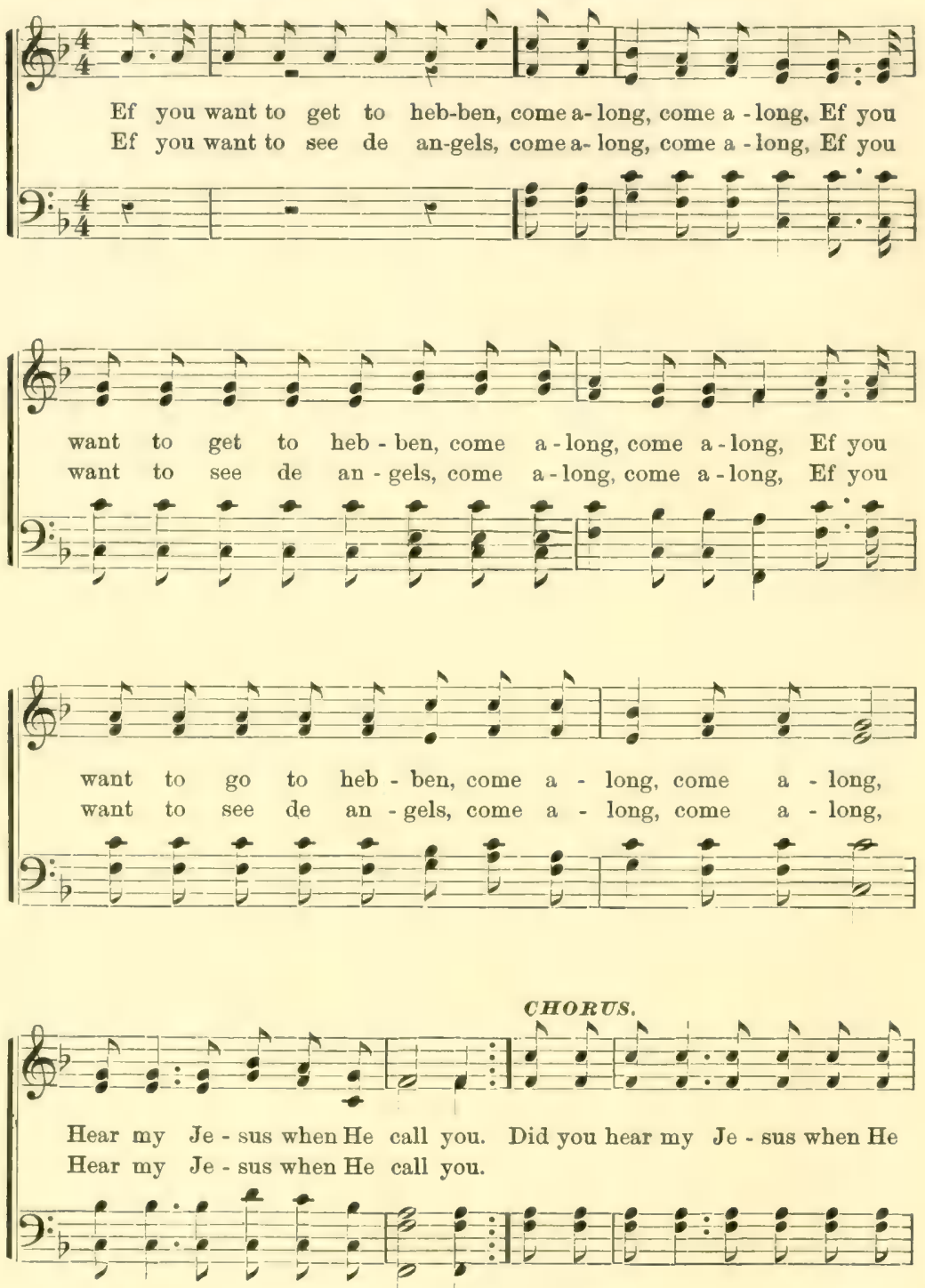
Thid you bear my Jesus.-Concluded.

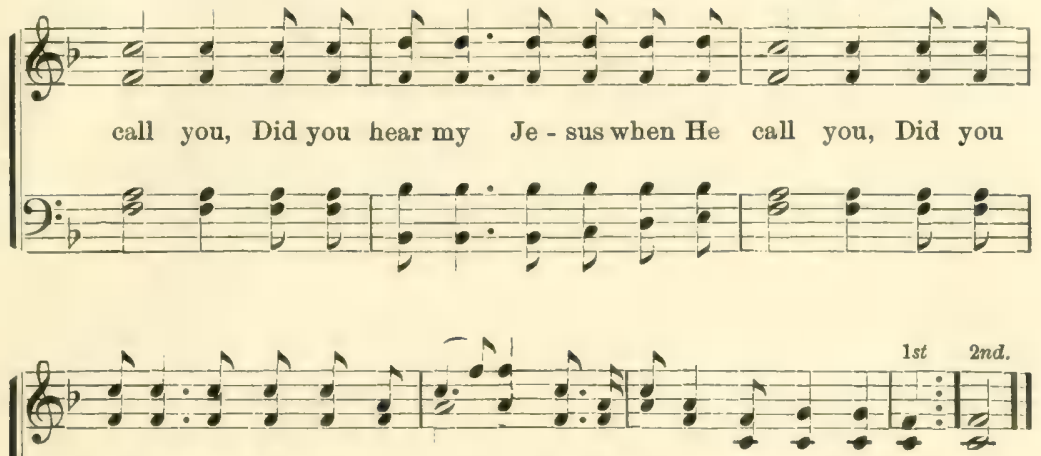

hear my Je - sus when $\mathrm{He}$ call you, For to try on your long white robe. robe.

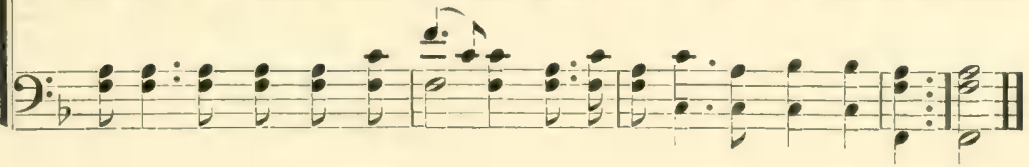

$2 \mathrm{Oh}$, de hebben gates are open, come along, come along,

Oh, de hebben gates are open, come along, come along, (bis.,

Hear my Jesus when He call you;

Oh, my mother's in de kingdom, come along, come along,

Oh, my mother's in de kingdom, come along, come along, (bis.,

Hear my Jesus when He call you,

I am gwine to meet her yander, come along, come along,

I am gwine to meet her yander, come along, come along, (bis.,

Hear my Jesus when He call you.

Сно.-Did you hear my Jesus when he call you,

Did you hear my Jesus when he call you, (bis,

For to try on your long white robe.

3 Ef you want to wear de slippers, come along, come along,

Ef you want to wear de slippers, come along, come along, (bis.,

Hear my Jesus when He call you;

Ef you want to lib forever, come along, come along,

Ef you want to lib forever, come along, come along, (bis.,

Hear my Jesus when He call you;

Did you hear my Jesus calling, "come along, come along,"

Did you hear my Jesus calling, "come along, come along." (bis.,

Hear my Jesus when He call you.

Cно.-Did you hear my Jesus when He call you,

Did you hear my Jesus when He call you, (bis.,

For to try on your long white robe. 
Zín, wrep a=low.
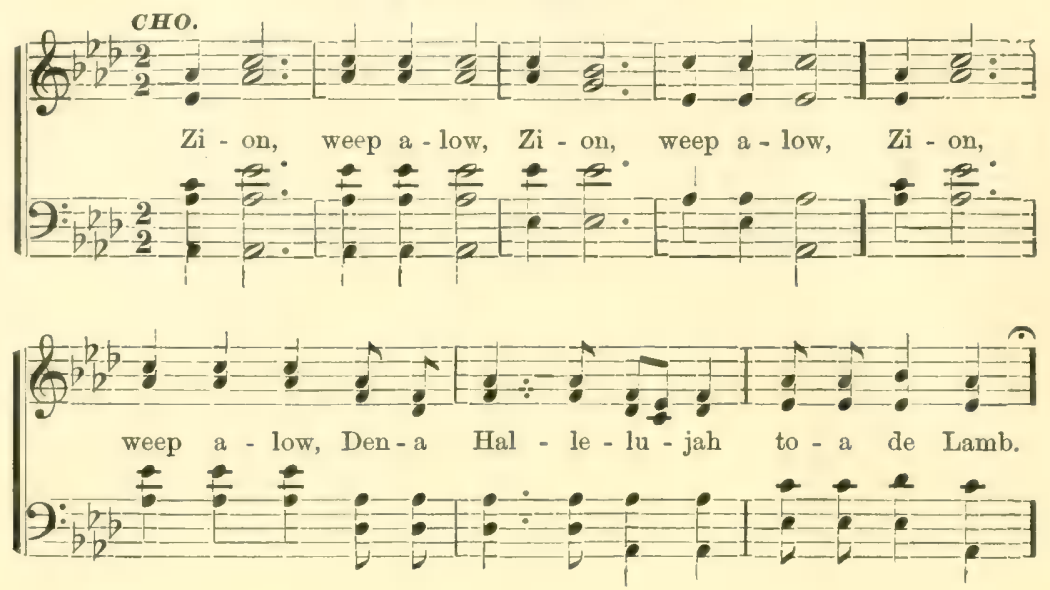

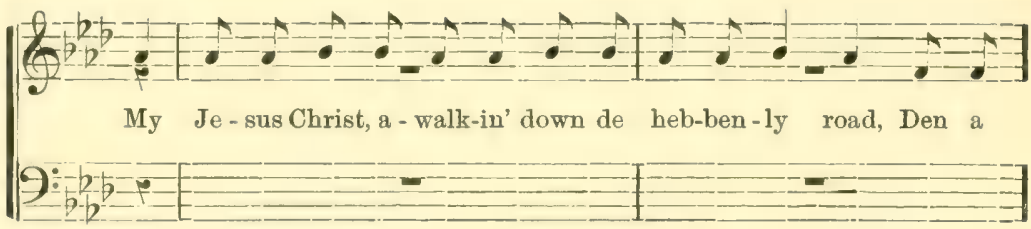

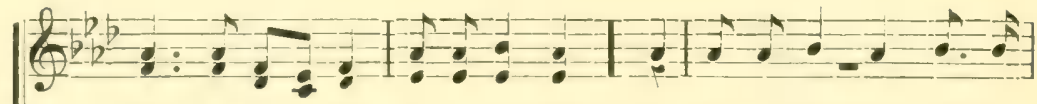

Hal - le-lu - jah to-a de Lamb, An' out o' his mouth come a
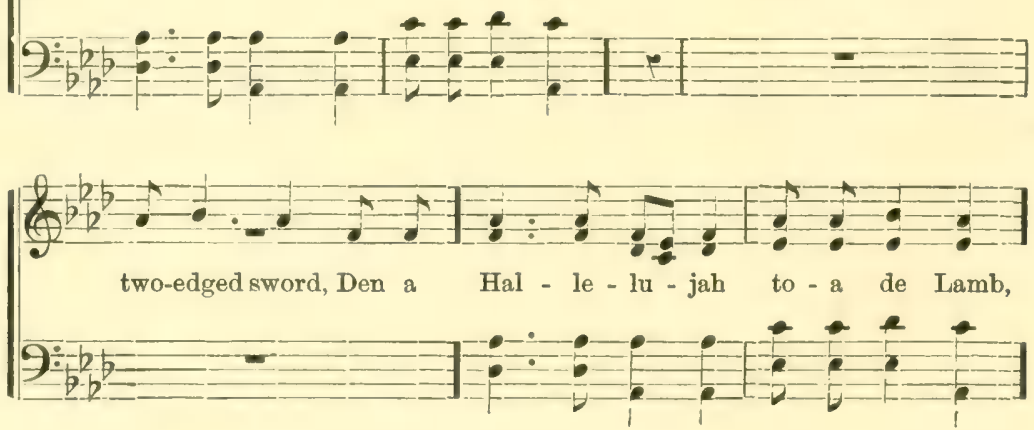


\section{Zion, werp a=low.-Concluded.}
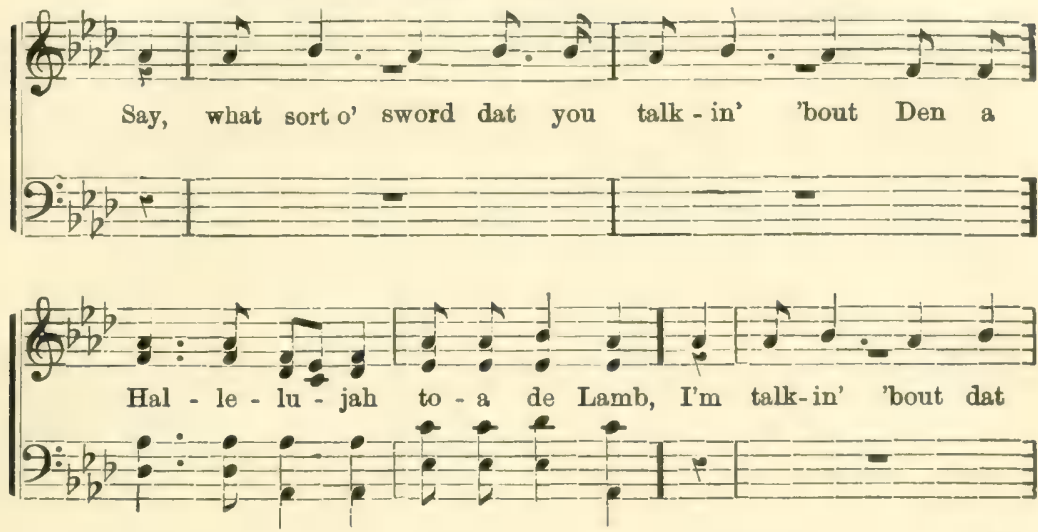

D.C.

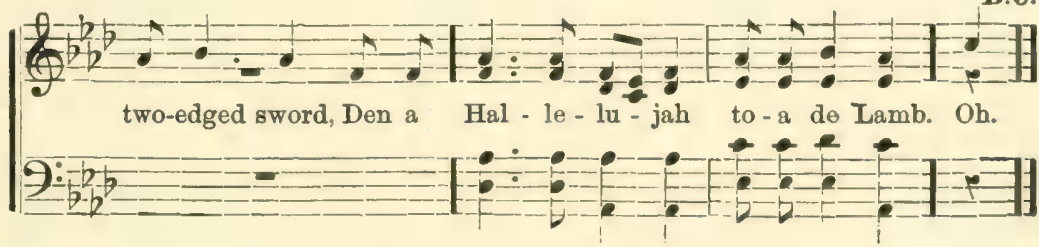

$2 \mathrm{Oh}$, look up yonder, Lord, a-what I see,

Den a Hallelujah, \&c.,

Dere's a long tall angel a comin' a'ter me,

Den a Hallelujah, \&c.,

Wid a palms o' vicatry in-a my hand,

Den a Hallelujah, \&c.,

Wid a golden crown a-placed on-a my head,

Den a Hallelujah, \&c. CHо.-Oh, Zion, weep a-low.

3 Zion been a-weepin' all o' de day,

Den a Hallelujah, \&c.,

Say, come, poor sinners, come-a an' pray,

Den a Hallelujah, \&c.,

Oh, Satan, like a dat huntin' dog,

Den a Hallelujah, \&c.,

He hunt dem a Christian's home to God,

Den a Hallelujah, \&c. Cно.-Oh, Zion, weep a-low.

$4 \mathrm{Oh}$, Hebben so high, an' I so low,

Den a Hallelujah, \&c.,

I don' know shall I ebber get to Hebben or no,

Den a Hallelujah, \&c.,

Gwine to tell my brudder befo' I go, Den a Hallelujah, \&c.,

What a dolesome road-a I had to go,

Den a Hallelujah, \&c. Сво._Oh, Zion, weep a-low. 


\section{Smert canaan.}

My mother used to tell me how the colored People all expected to be free some day, and how one night, a great many of them met together in a Cabin, and tied little budgets on their backs, as though they expected to go off some where, and cried, and shook bands, and sang this bymn.

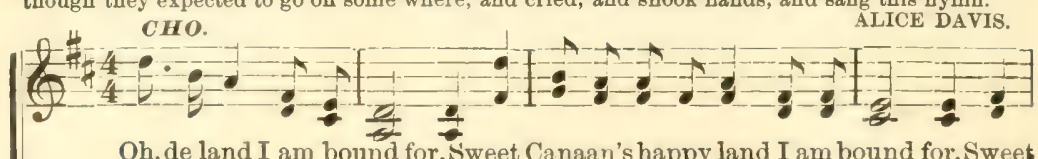

Oh, de land I am bound for, 'weet Canaan's happy land I am bound for, Sweet
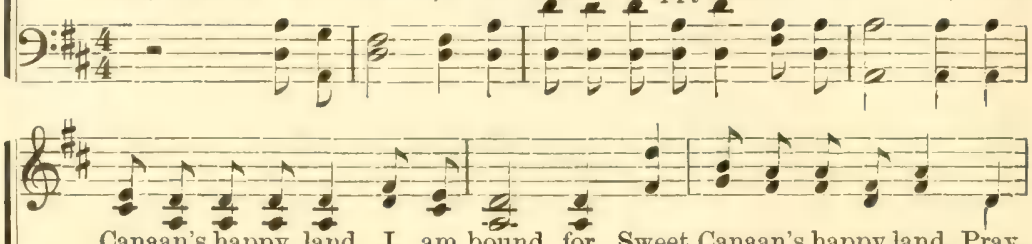

Canaan's happy land I am bound for, Sweet Canaan's happy land, Pray,
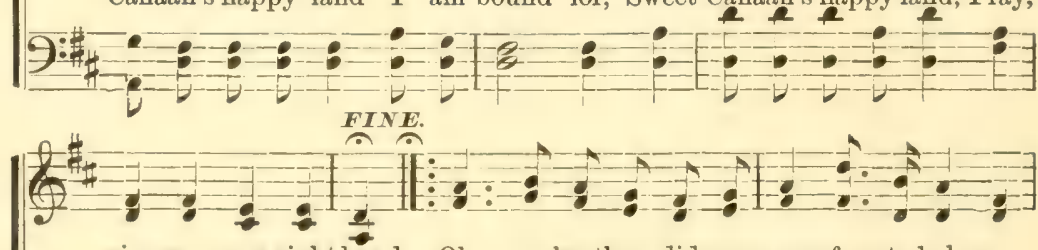

give me your right hand. Oh, my brother, did you come for to help me,
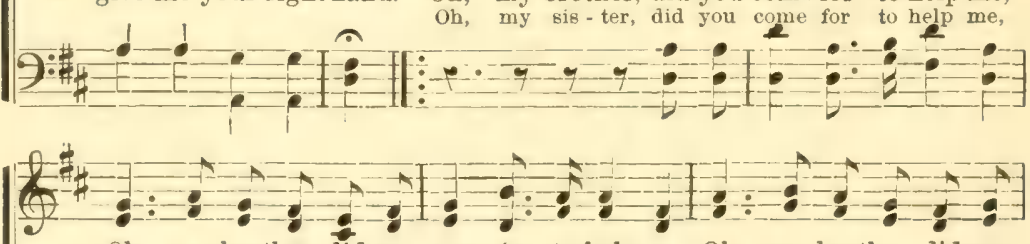

$\mathrm{Oh}$, my brotber, did you come for to help me, Oh, my brother, did you

Oh, my ris-ter, did you come for to halp me, Oh, my sis-ter, did you
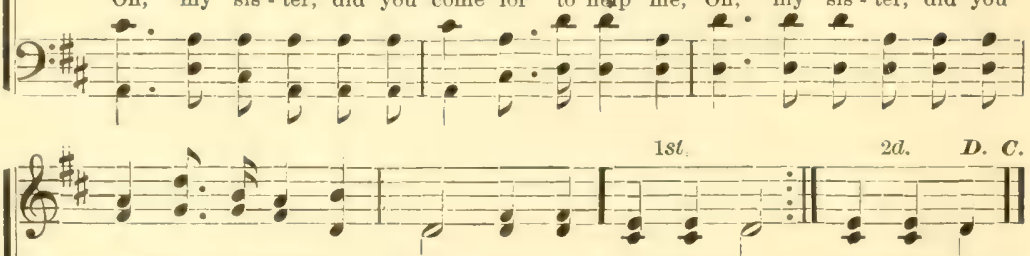

come for to help me; Pray, give me your right hand, your right hand.

come for to help me; Pray, \&c.

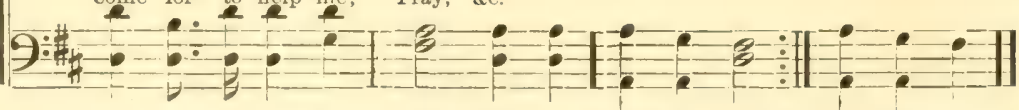

Noтв.-There is so little variety to the verses of "Sweet Canaan" that we have not thonght it worth while to give them at greater length. They readily suggest themselves, sud seem to be limited only by the number of the sinte 's re'ations and friends. 


\section{En tat great gittín=up ettornin?.}

THIs song is a remarkable paraphrase of a portion of the Book of Revelations, and one of the finest specimens of pegro "Spirituals." The student who brought it to us, and who sings the Solos, has furuished all that he can remember of the almost interminable succession of verses, which he has heard sung for half an hour at a time, by the slaves in their midnight meetings in the woods. He gives the following interesting account of its origin :

"I have heard my uncle sing this hymn, and he told me how it was made. It was made by an old slave who knew nothing about letters or figures. He could not count the number of rails that he would split when he was tasked by his master to split 150 a day. But he tried to lead a Christian life, and he dreamed of the General Judgment, and told his fellow-servants about it, and then made a tune to it, and sang it in his cabin meetings."

J. B. Towe.
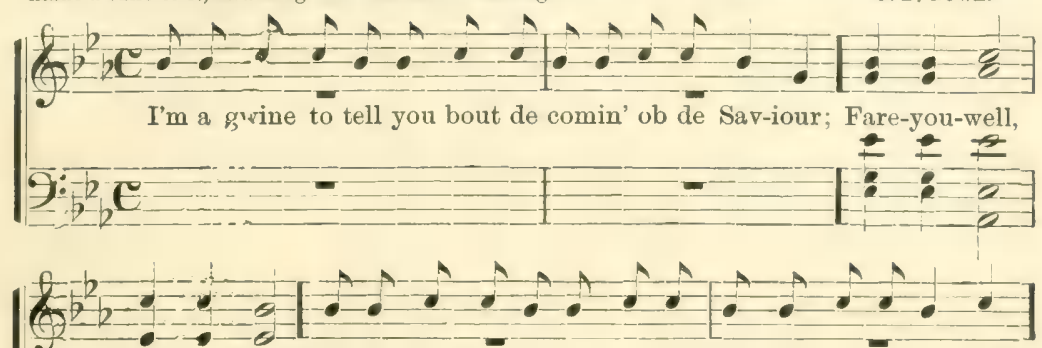

Fare you-well. I'm a gwine to tell you 'bout de com - in ob de Saviour;
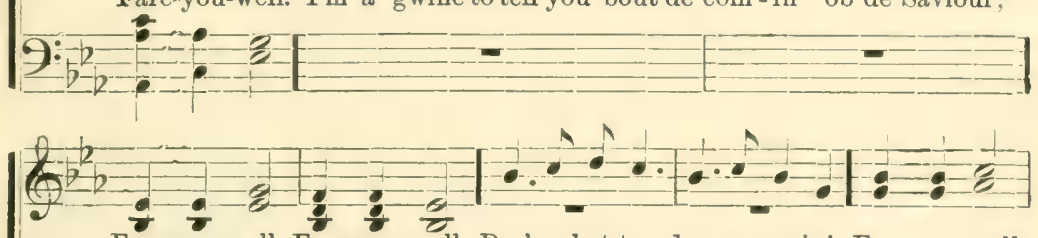

Fare-you-well, Fare-you-well. Dar's a bet-ter day a comin'; Fare-you-well,
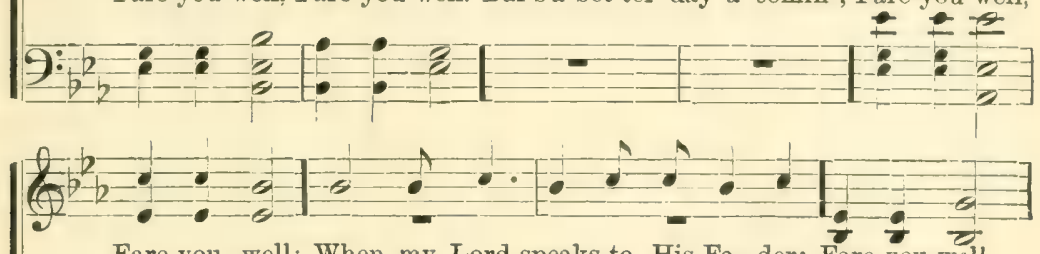

Fare-you-well; When my Lord speaks to His Fa-der; Fare-you-well,
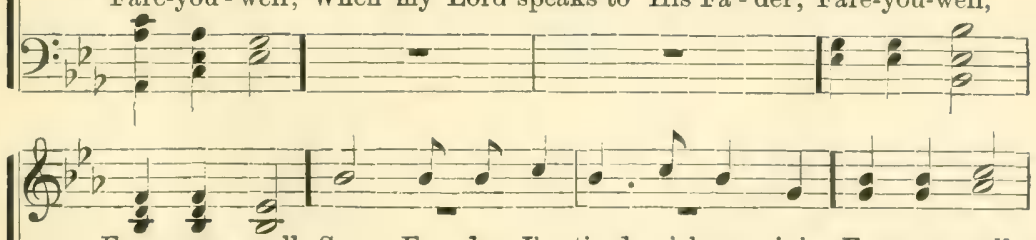

Fare-you - well. Says Fa-der, I'm tired o' bear - in', Fare-you-well.

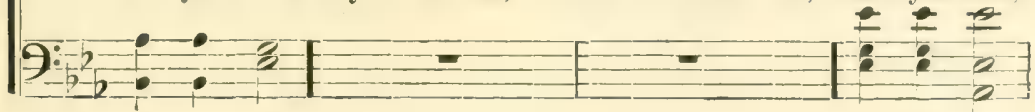


I) nat great gittin=up ftlornim'-Continued.
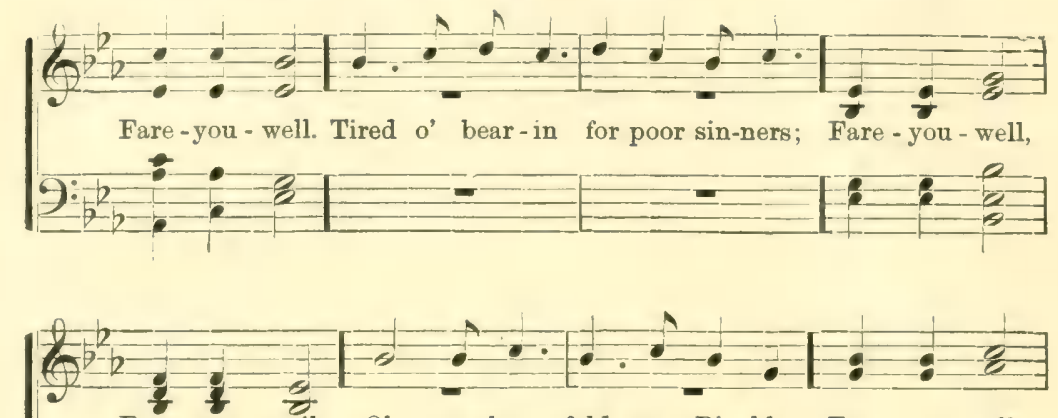

Fare-you - well. Oh, preachers, fold your Bi - bles; Fare-you-well;
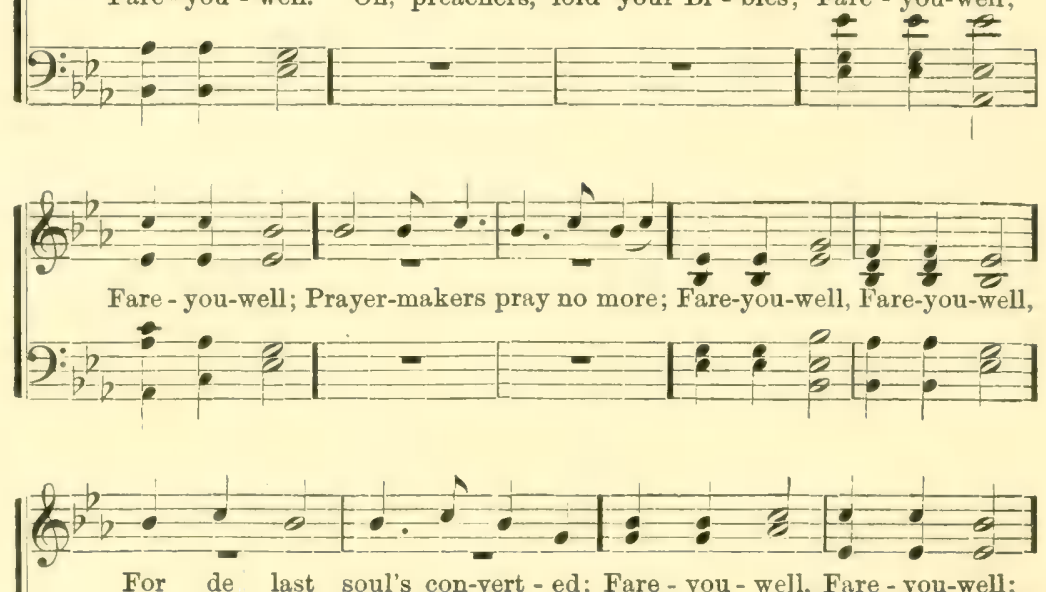

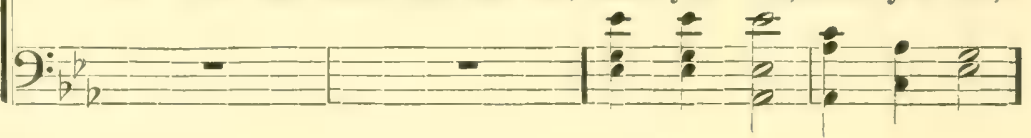

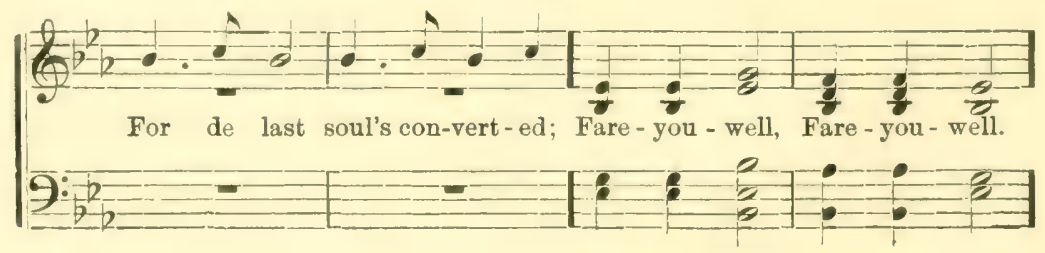


In dat great gittin=up fttornin'.-Concluded. CHORUS.

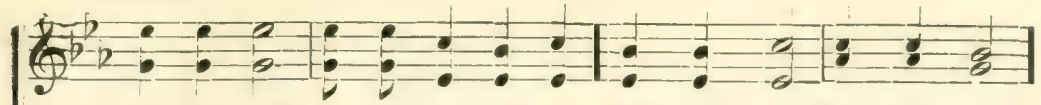

In dat great get - tin - up morn-in; Fare - you - well, Frare-you - well,
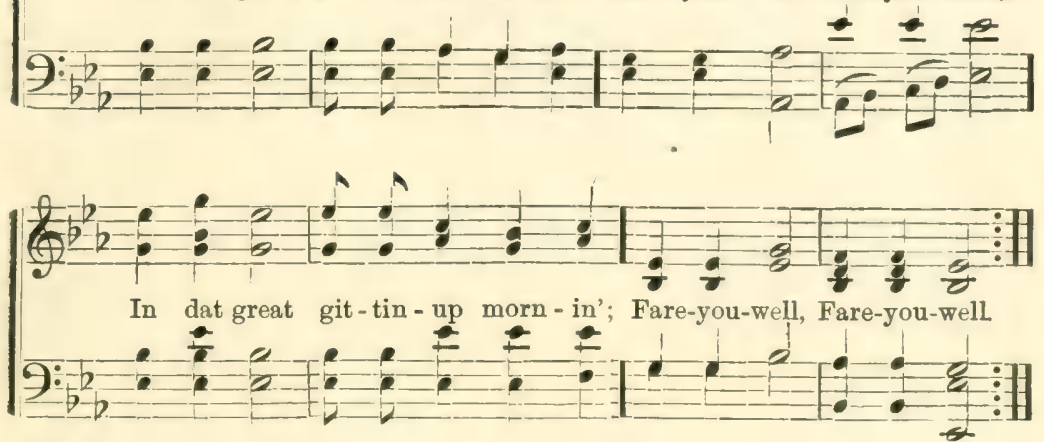

2. Dere's a better day a comin',

3. When my Lord speaks to his Fader,

4. Says, Fader, I'm tired o' bearin',

5. Tired o' bearin' for poor sinners,

6. Oh preachers, fold your Bibles,

7. Prayer-makers, pray no more,

8. For de last soul's converted.(bis)Cho.

9. De Lord spoke to Gabriel.

10. Say, go look behind de altar,

11. Take down de silver trumpet,

12. Go down to de ser-side,

13. Place one foot on de dry land,

14. Place de oder on de sea,

15. Raise your hand to heaven,

16. Declare by your Maker,

17. Dat time shall be no longer. (bis) Cho.

18. Blow your trumpet, Gabriel.

19. Lord, how loud shall I blow it?

20. Blow it right calm and easy,

21. Do not alarm my people,

22. Tell dem to come to judgment. (bis) Cho.

23. Den you see de coffins bustin',

24. Den you see de Christian risin'

25. Den you see de righteous marchin',

26. Dey are marchin' home to heaven.

27. Den look upon Mount Zion,

28. You see my Jesus comin'

29. Wid all his holv angels.

30. Where you runnin', sinner?
31. Judgment day is comin'. (bis) Cho.

32. Gabriel, blow your trumpet,

33. Lord, how loud shall I blow it?

34. Loud as seven peals of thunder,

35. Wake de sleepin' nations.

36. Den you see poor sinners risin'.

37. See de dry bones a creepin', Cho.

38. Den you see de world on fire,

39. You see de moon a bleedin',

40. See de stars a fallin',

41. See de elements meltin',

42. See d6 forked lightnin',

43. Hear de rumblin' thunder.

44. Earth shall reel and totter,

45. Hell shall be uncapped,

46. De dragon shall te loosened.

47. Fare-you-well, poor sinner. Cho.

48. Den you look up in de heaven,

49. See your mother in heaven,

50. While you're doomed to destruction.

51. When de partin word is given.

52. De Christian shouts to your ruin.

53. No mercy'll ever reach you, Cho.

54. Den you'll cry out for cold water,

55. While de Christian's shoutin' in giory

56. Sayin' amen to your damnation,

57. Den you hear de sinner sayin',

58. Down I'm rollin', down I'm rollin',

59. Den de righteous housed in heaven,

60. Live wid God forever. (bis.) Cho. 


\section{Jetalk nou in de $\mathfrak{z}$ ight.}
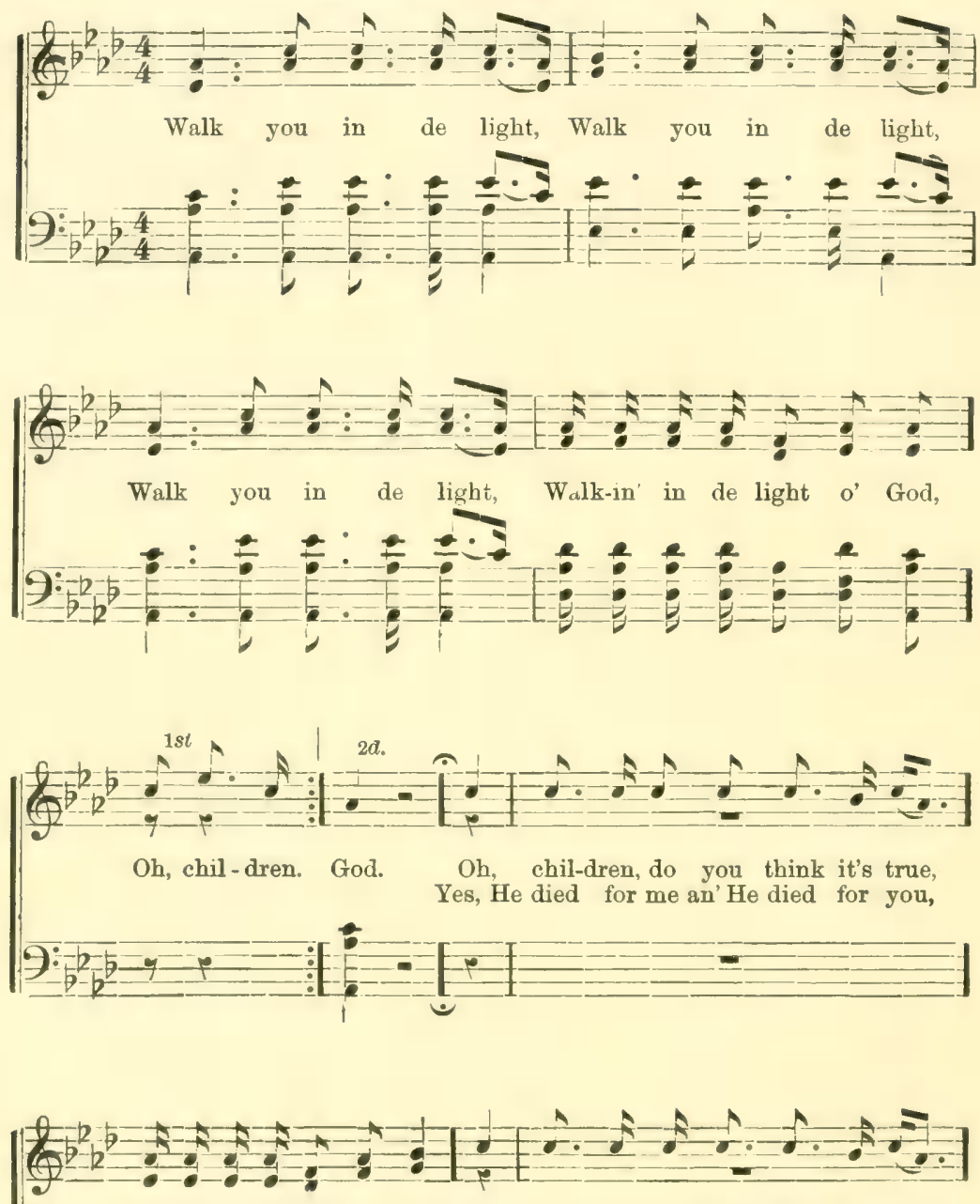

Walkin' in de light $o^{\prime}$ God, Dat Je - susChrist did die for you, For de Ho - ly Bi - ble does say so,

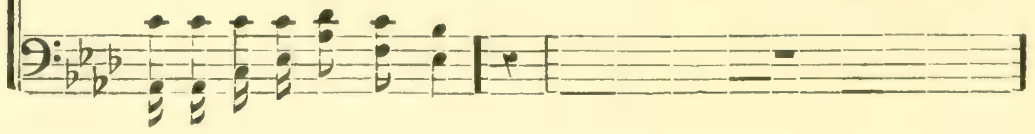




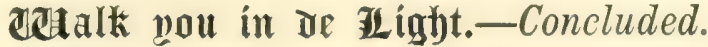

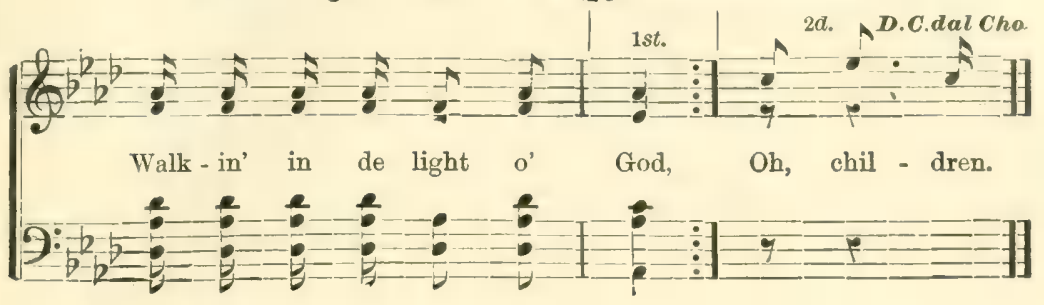

2 I think I heard some children say,

Walkin' in de light o' God,

Dat dey neber heard de'r parents pray,

Walkin' in de light o' Grod.

$\mathrm{Oh}$, parents, dat is not de way,

Walkin' in de light o' God,

But teach your children to watch an' pray,

Walkin' in de light o' God.

Сно.-Oh, parents, walk you in de light,

Walk you in de light, walk you in de light,

Walkin' in de light o' God.

3 I love to shout, I love to sing,

Walkin' in de light o' God,

I love to praise my Heavenly King,

Walkin' in de light o' God.

Oh, sisters, can't you help me sing,

Walkin' in de light o' God,

For Moses' sister did help him,

Walkin' in de light o' God.

Cro.-Oh, sisters, walk you in de light, \&c.

$4 \mathrm{Oh}$, de heavenly lan' so bright an' fair,

Walkin' in de light o' God,

A very few dat enter dere,

Walkin' in de light o' God.

For good Elijah did declare,

Walkin' in de light o' God,

Dat nothin' but de righteous shall go ders

Walkin' in de light o' God.

Cro.-Oh, Christians, walk you in de light, \&c. 


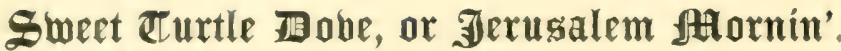
pp 1st, 4 th and 8 th verses only.

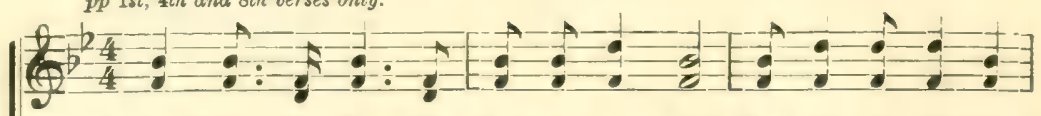

1 Sweet tur - tle dove, she sing-a so sweet, Mud-dy de wa-ter,
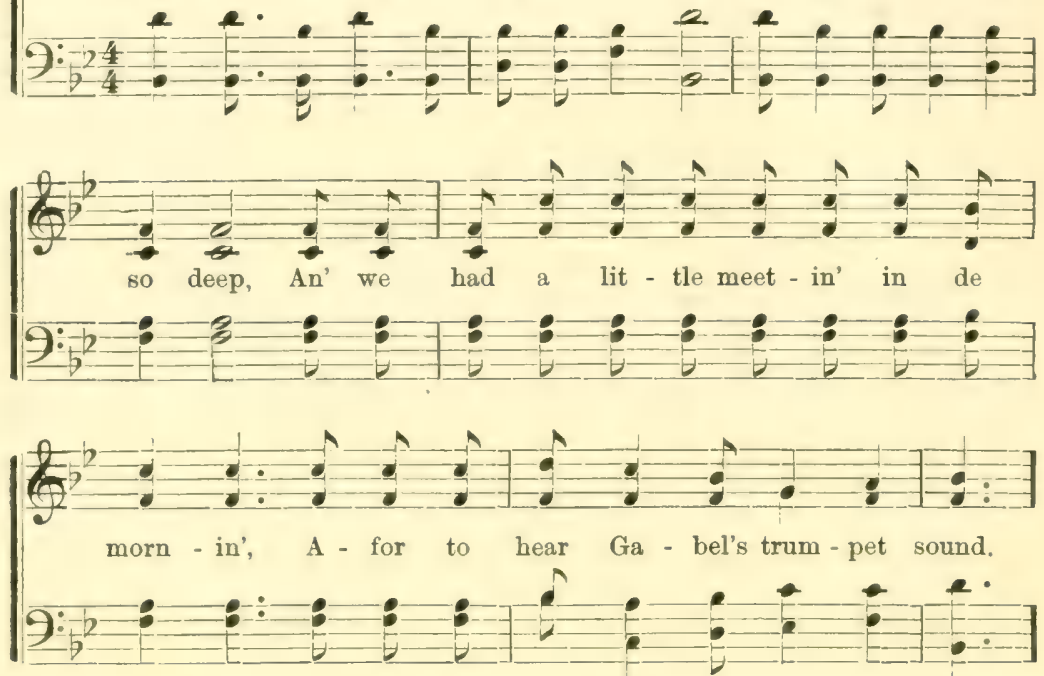

\section{CHORUS.}
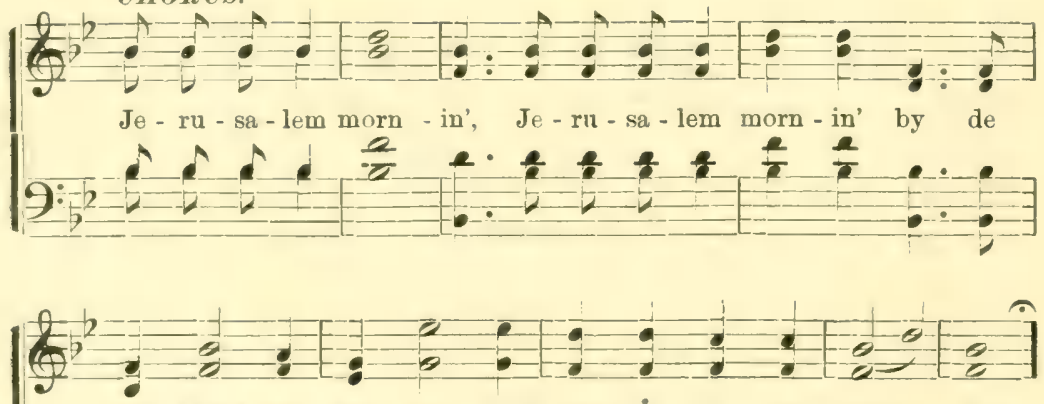
light, Don't you hear Ga - bel's trum-pet in dat morn - in'?

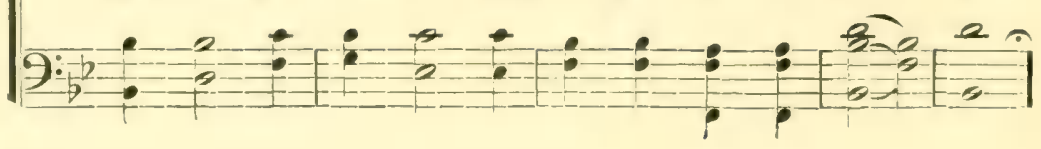




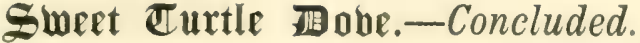

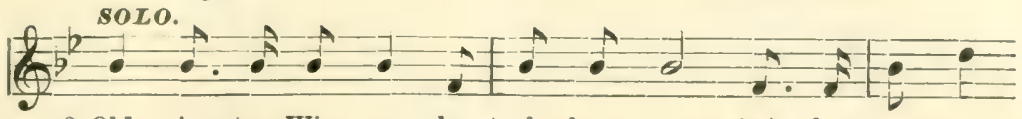

2 Old sis - ter Win - ny, she took her seat, An' she want all

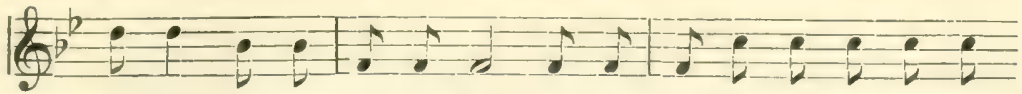

de mem-bers to fol-ler her, An' we had a lit-tle meet-in'

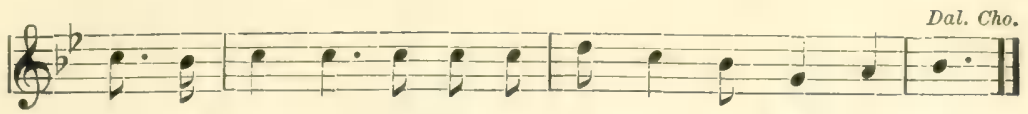

in de morn-in', A-for to hear Ga-bel's trum-pet sound.

2 Ole sister Hannah, she took her seat, An' she want all de member to foller her;

An' we had a little meetin' in de mornin', A-for to hear Gabel's trumpet sound.

Cно.-Jerusalem mornin', \&c.

3 Sweet turtle dove, she sing-a so sweet, Muddy de water, so deep,

An' we had a little meetin' in de mornin', A-for to hear Gabel's trumpet sound.

Сно._Jerusalem mornin', \&c.

(Soso.) 5 Ole brudder Philip, he took his seat, An' he want all de member to foller him,

An' we had a little meetin' in de mornin,' A-for to hear Gabel's trumpet sound.

Сно.--Jerusalem mornin', \&c.

(Souo.) 6 Ole sister Hagar, she took her seat,

An' she want all de member to foller her,

An' we had a little meetin' in de mornin',

A-for to hear Gabel's trumpet sound,

Cно.-Jerusalem mornin', \&c.

(SoLo.) 7 Ole brudder Moses took his seat, An' he want all de member to foller him,

An' we had a little meetin' in de mornin',

A-for to hear Gabel's trumpet sound.

Cно.-Jerusalem mornin', \&c.

8 Sweet turtle dove, she sing-a so sweet,

Muddy de water. so deep,

An' we had a little meetin' in de mornin'.

A-for to hear Gabel's trumpet sound.

Cro.-Jerusalem mornin', \&c. 


\section{Grioeon's band; or, Je milk=white Jigrorses.}

The explanation which has been given us of the origin of this curious hymn is, we think, in valuable as an example of the manner in which external facts grew to have a strange symbolical meaning in the imaginative mind of the negro race.

In a little town in one of the Southern States, a Scriptural panorama was exhibited, in which Gideon's Band held a prominent place, the leader being conspicuously mounted upon a white horse. The black people of the neighborhood crowded to see it, and suddenly, and to themselves inexplicably, this swinging "Milk-White Horses" sprang up amoug them, establishing itself soon as a standard church and chimuey-corner hymn.

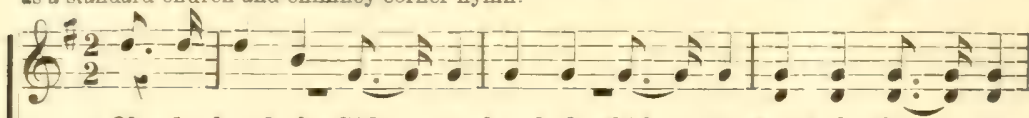

Oh, de band ob Gid-e-on, band ob Gid-e-on, band ob Gid-e-on,

Oh, de milk-white bor - ses, milk-white hor - ses, milk-white hor - ses,
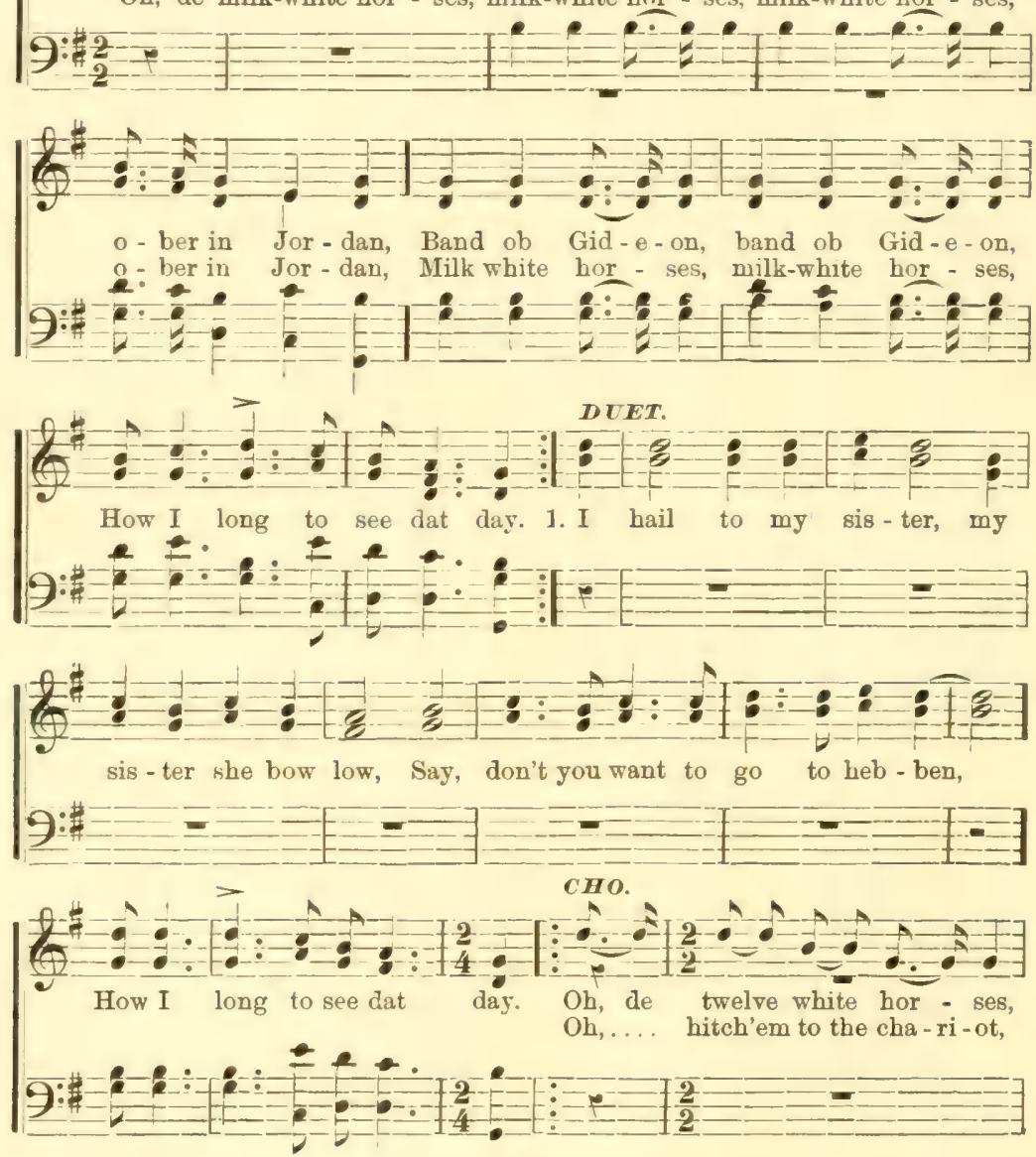
Gíren's Band.-Concluded.
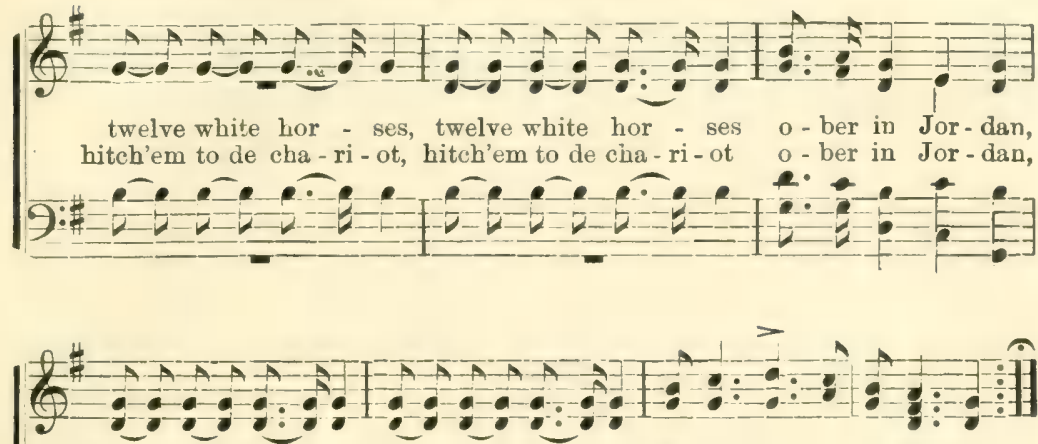

Twelve white hor - ses, twelve white hor - ses, How I long to see dat day.

Hitch 'em to the chariot, hitch'em to the chariot, How I long, \&c.

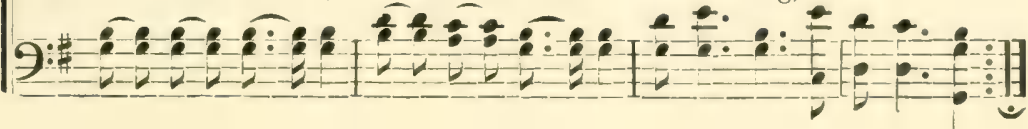

\& Doo.-I hail to my brudder, my brudder he bow low,

Say, den't you want to go to hebben?-

How I long to see dat day!

Сно.--Oh, ride up in de chariot, ride up in de chariot, Ride up in de chariot ober in Jordan ;

Ride up in de chariot, ride up in de chariot-

How I long to see dat day!

It's a golden chariot, a golden chariot,

Golden chariot ober in Jordan ;

Golden chariot, a golden chariot-

How I long to see dat day!

3 Doo. - I hail to de mourner, de mourner he bow low,

Say, don't you want to go to bebben?-

How I long to see dat day!

Сво._Oh, de milk an' honey, milk an' honey,

Milk an' honey ober in Jordan ;

Milk an' honey, milk an' honey-

How I long to see dat day!

$\mathrm{Oh}$, de healin' water, de healin' water,

Healin' water ober in Jordan ;

Healin' water, de healin' water-

How I long to see dat day ! 


\section{理e retintex'll soou be Guer.}
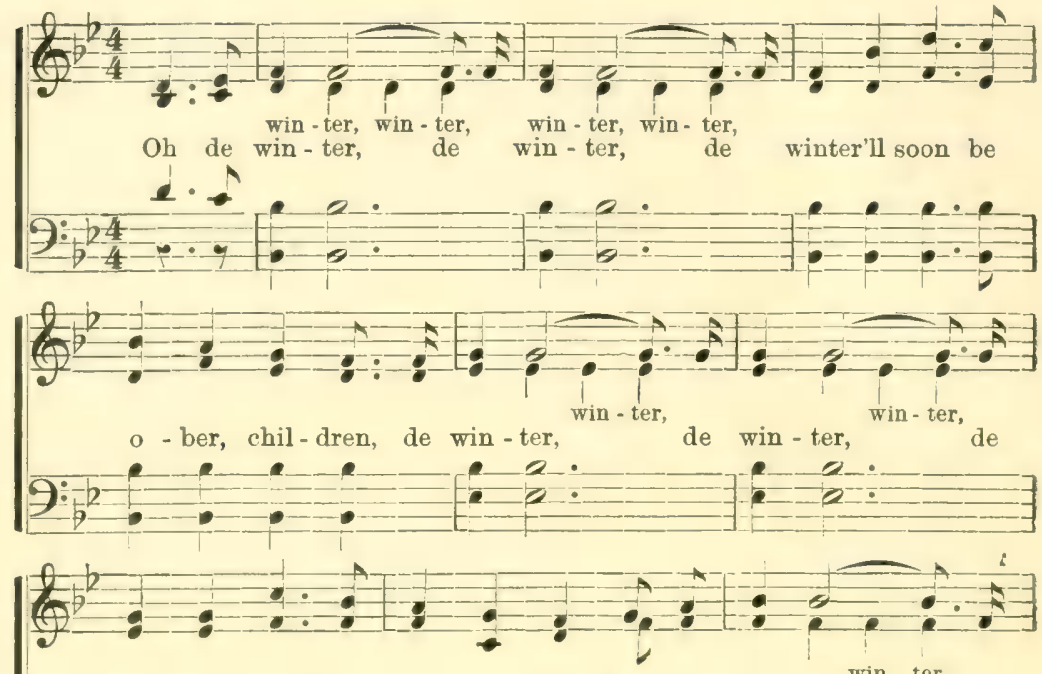

win - ter'll soon be o - ber, chil - dren, de win-ter,
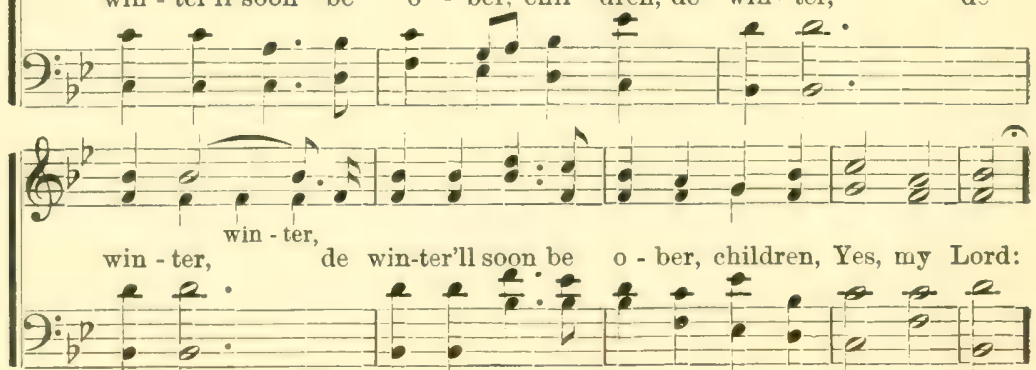

(9):Oh look up yon-der what I see, Bright angels com-in' ar - ter me.

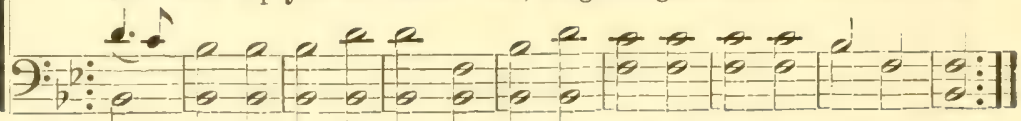

2 I turn my eyes towards de sky,

An' ask de Lorả for wings to fly;

If you get dere before I do, Look out for me I'm comin' too. Cho. We'll shout, an' sing forebber more. Cho. An' wheu we get on Canaan's shore,

3 Ob Jordan's ribber is deep an' wide, But Jesus stan' on de hebbenly side; 
Jatep fte from sinkin' Jown.
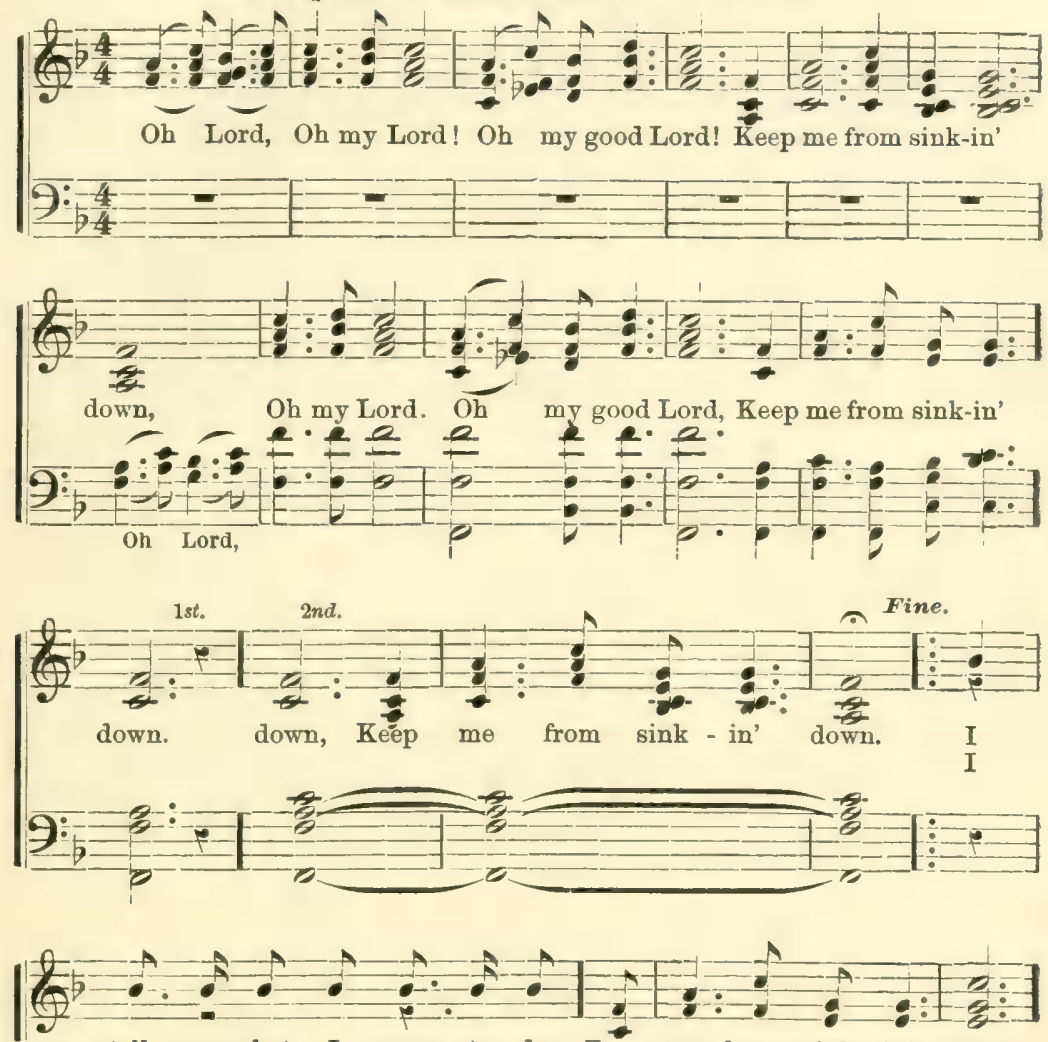

tell you what I mean to do, Keep me from sink - in' down,

bless de Lord I'm gwine to die. Keep me from sink - in' down,

$9: \bar{z}=$

I mean to go to heb - ben too, Keep me from sink -in' down.
gwine to judgment by an' by. Keep me from sink -in' down. 

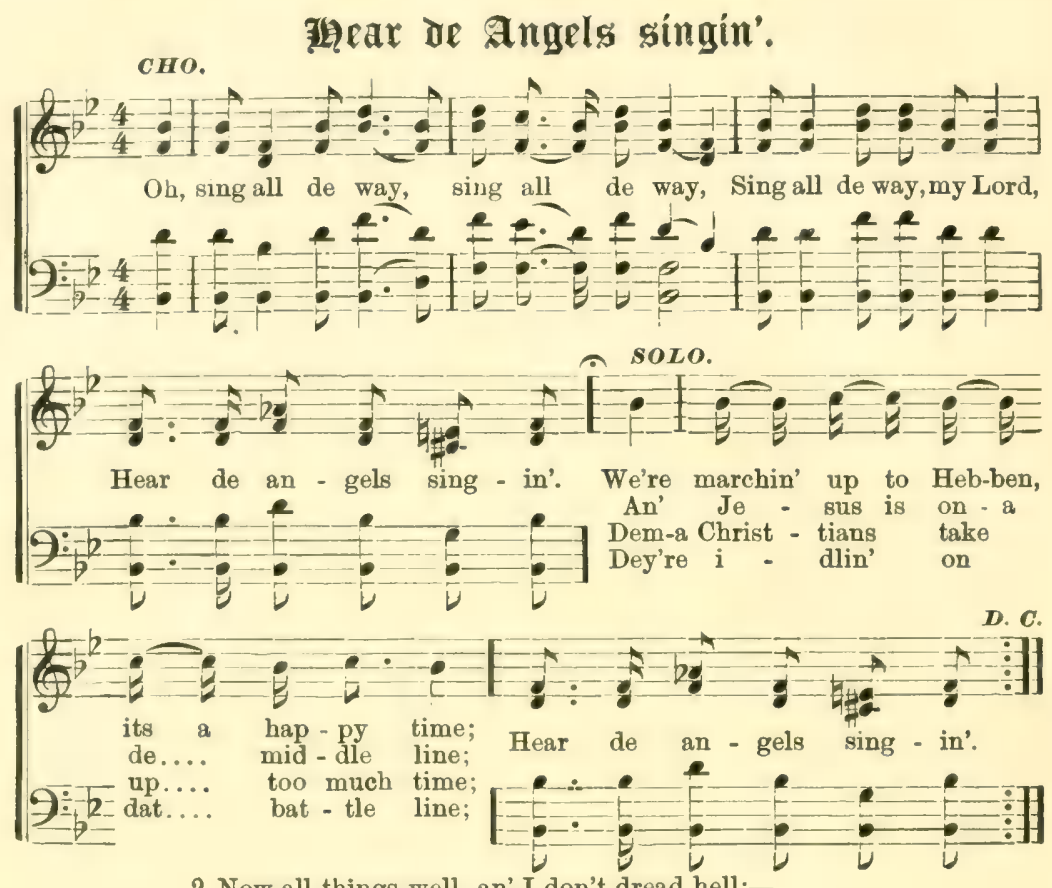

2 Now all things well, an' I don't dread hell;-

Hear de angels singin',

I am goin' up to Hebben, where my Jesus dwell; Hear de angels singin'.

For de angels are callin' me away,Hear de angels singin',

An' I must go, I cannot stay, Hear de augels singin'.

Cно._Oh, sing, \&c.

3 Now take your Bible, an' read it through,-

Hear de angels singin',

An' ebery word you'll find is true;-

Hear de angels singin'.

For in dat Bible you will see,Hear de angels singin',

Dat Jesus died for you an' me,Heur de angels singin'.

Cro. - Oh, sing, \&c.

4 Say. if my memory sarves me right,Hear de angels singin',

We're sure to hab a little shout to-night,Hear de angels singin'.

For I love to shout, I love to sing,Hear de angels singin',

I love to praise my Hebbenly King,Hear de angels singin'.

Сно.- Oh, sing, \&c. 


\section{If'be been a=list'ning all ore Night long.}
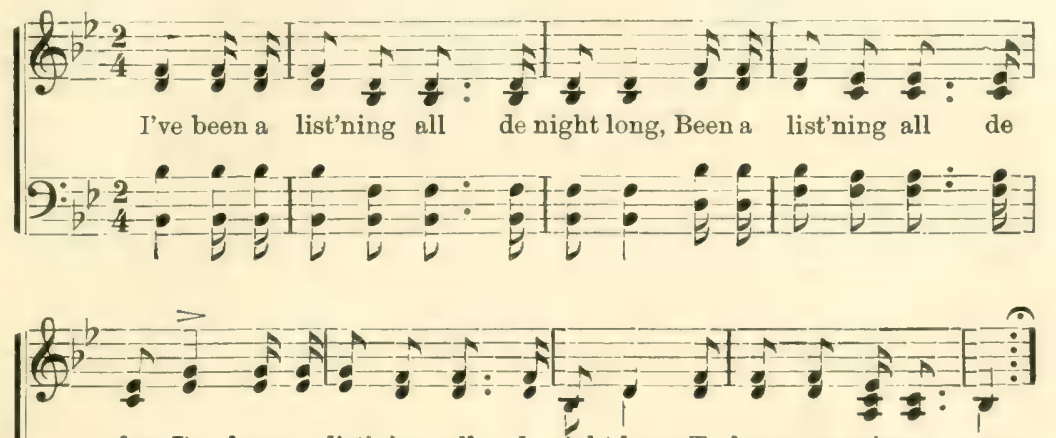

day, I've been a list'ning all de night long, To hear somesinner pray.
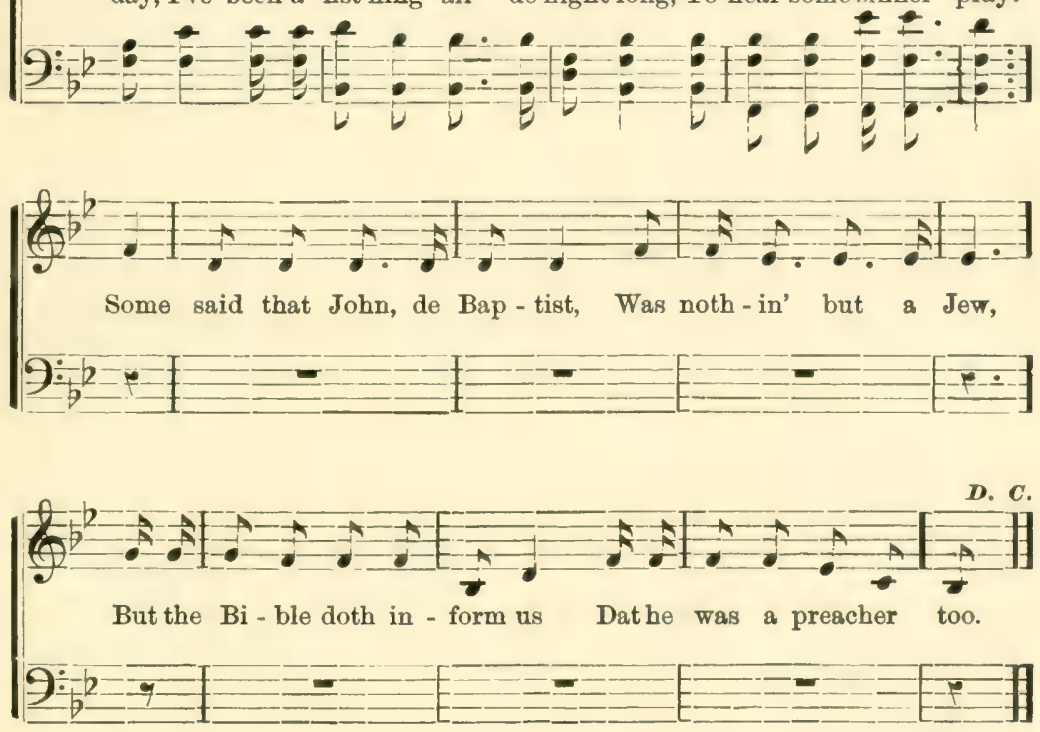

2.

Go, read the fifth of Matthew, An' a read de chapter thro',

It is de guide to Christians, An' a tells dem what to do.

Сно.-I've been a list'ning, \&c.
3.

Dere was a search in heaven, An' a all de earth around, John stood in sorrow hoping Dat a Saviour might be found. Сно.-I've been a list'ning, \&c. 


\section{Babplon's ffallin'.}

This is often used In Hampton as a Marching song, and is quite effective when the two hundred atudents are filing out of the assembly room to its spirited movement. We recommend it for gimilar use to Schools and Kindergartens.
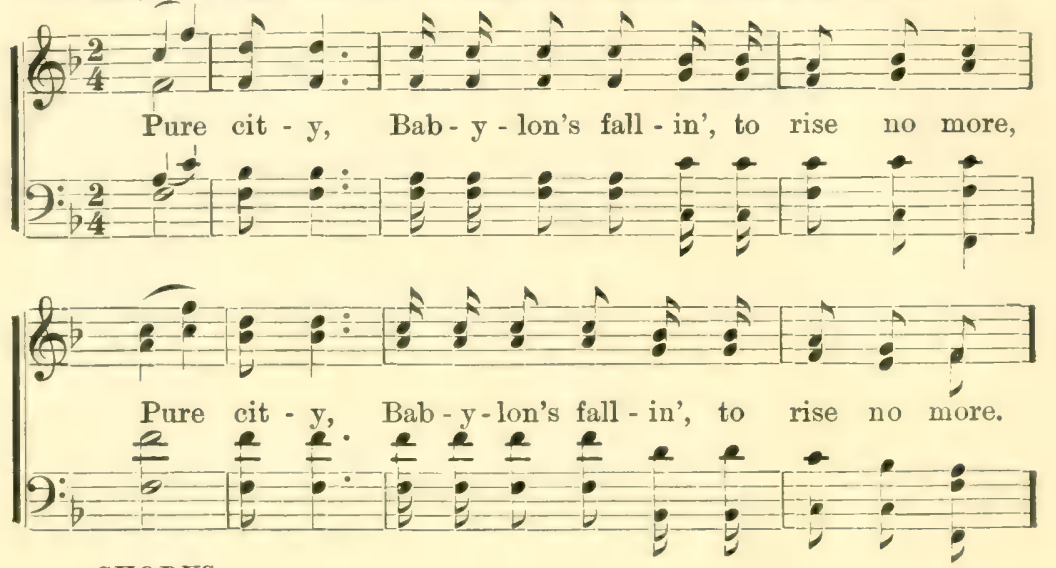

CHORUS.

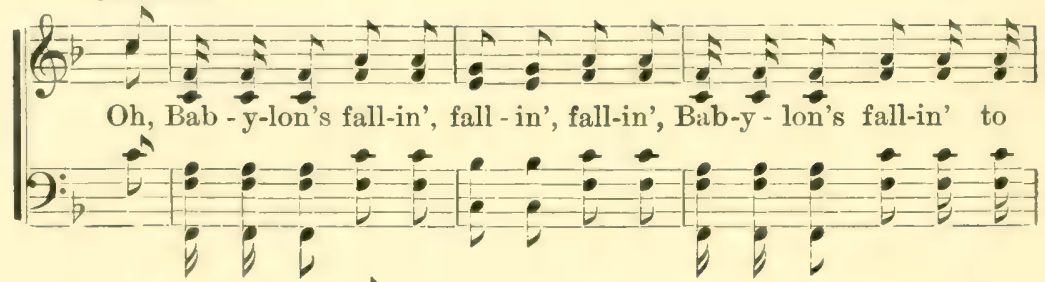

(6):

rise no more, Oh, Bab-y -lon's fall - in', fall - in', fall - in',

再:

(9)

Bab - y -lon's fall - in' to rise no more. Oh, Je - sus tell you

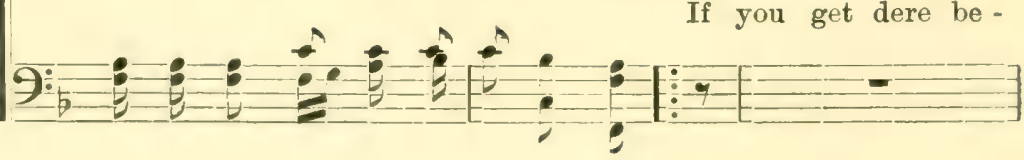


Babnlon's ffallin'.-Concluded.
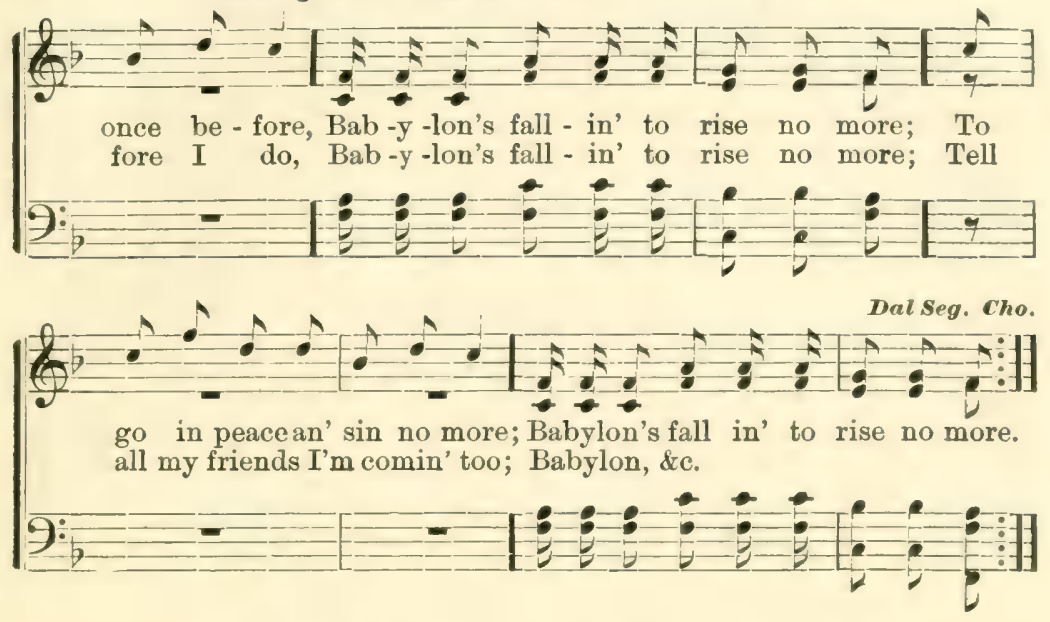

De ole Ark a=moberin' along.
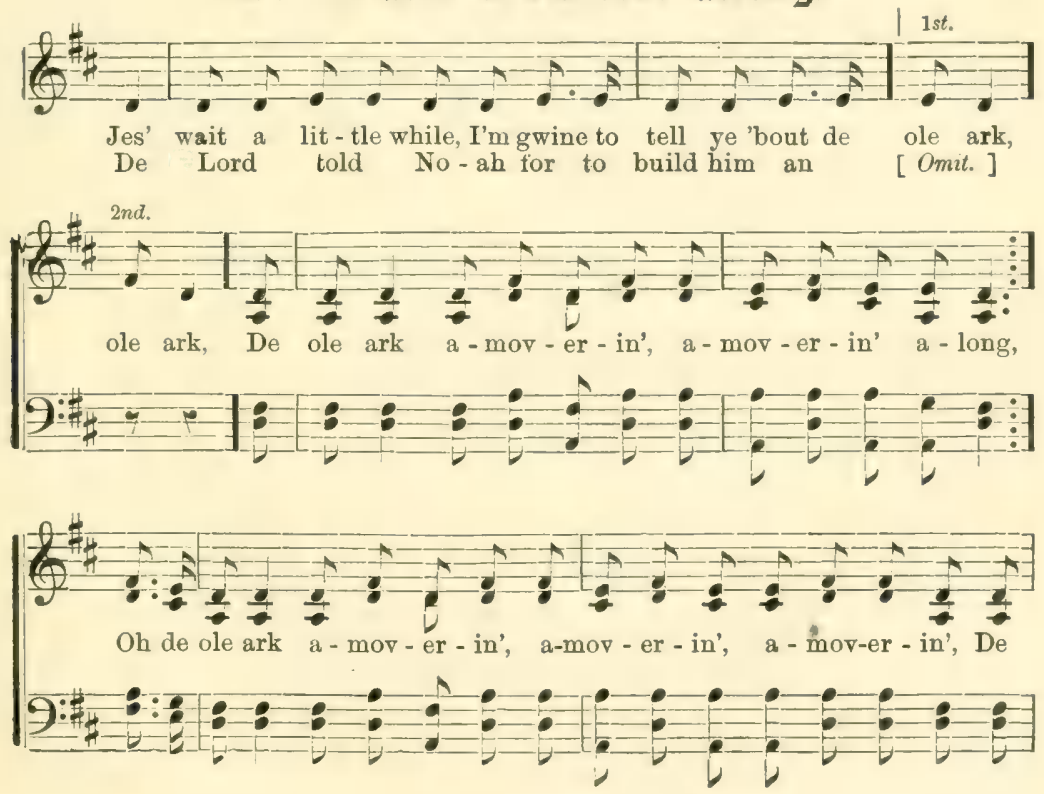


\section{The ole Ark a=moberin' Along.-Concluded.}

Omit in the last verse,
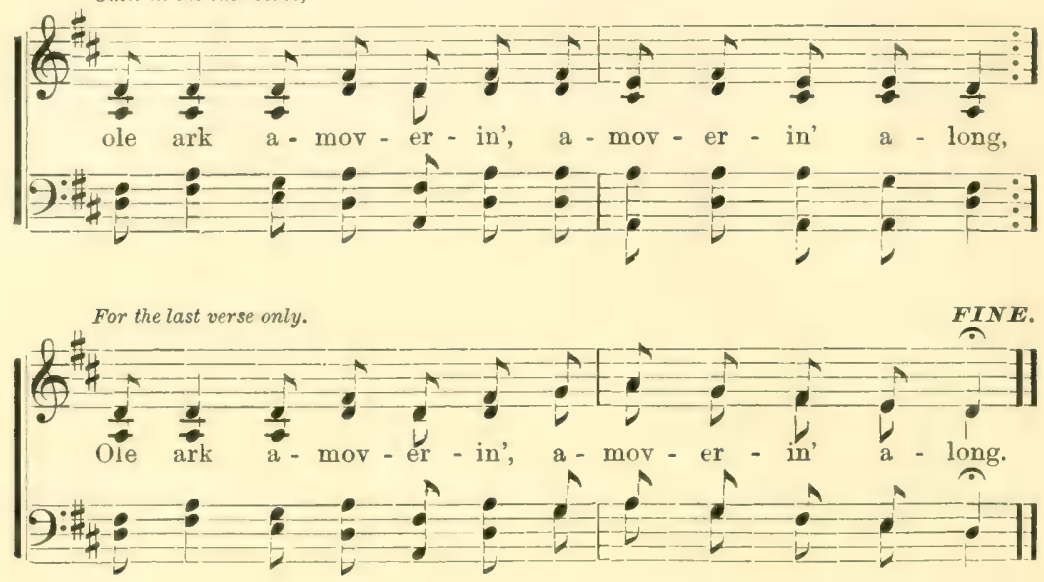

2 Den Noah an' his sons went to work upon de dry lan',

De ole ark a-moverin', \&c.,

Dey built dat ark jes' accordin' to de comman',

De ole ark a-moverin', \&c.,

Noah an' his sons went to work upon de timber,

De ole ark a-moverin', \&c.,

De proud began to laugh, an' de silly point de'r finger,

De ole ark a-moverin', \&c.

Cно._De ole ark a-moverin', \&c.

3 When de ark was finished jes' accordin' to de plan,

De ole ark a-moverin', \&c.,

Massa Noah took in his family, both animal an' man,

De ole ark a-moverin, \&c.,

When de rain began to fảll an' de ari began to rise,

De ole ark a-moverin', \&c.,

De wicked hung arcund' wid der groans an' de'r cries,

De ole ark a-moverin,' \&c.

Сно.-Oh de ole ark a-moverin, \&c.

4 Forty days an' forty nights, de rain it kep' a fallin',

De ole ark a-moverin', \&c.

De wicked clumb de trees, an' for help dey kep' a callin',

De ole ark a-moverin', \&c.,

Dat awful rain, she stopped at last, de waters dey subsided,

De ole ark a-moverin', \&e.,

An' dat ole ark wid all on board on Ararat she rided,

De ole ark a-moverin', \&c.,

Cho.-Oh, de ole ark a-moverin, \&c. 
刃ust an' Astes.

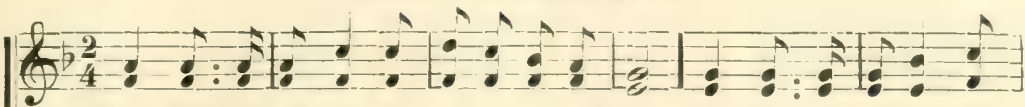

1. Dust, dust an' ash - es fly ov-er on mygrav?, Dust, dust an' ash-es fly

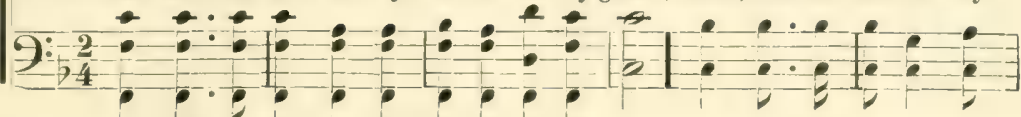
V V V V V V V

$(6900$ o-ver on my grave, Dust, dustan' ash - es fly o-ver on my grave,

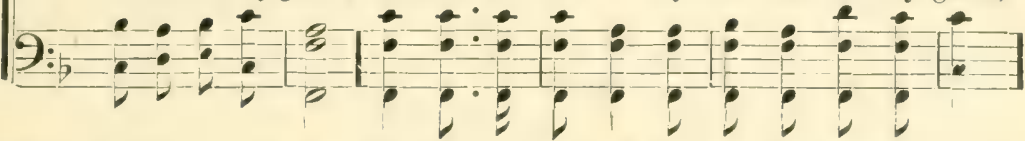
(6)

An' de Lord shall bear my spir-it home, An' de Lord shall bear my spirit home.

$9 \div$

(6):-1:

2. Dey cru - ci - fied my Sav - iour, An' nailed Him to de cross, Dey

3. Oh, Jo-seph begged his bo-dy, An' laid it in de tomb, Oh,

4. De an-gel came from heav-en, An' roll de stone a-way, De

5. De cold grave could not hold Him, Nor death's cold i - ron band, De

$9: \frac{9}{5}: \frac{1}{2}=$

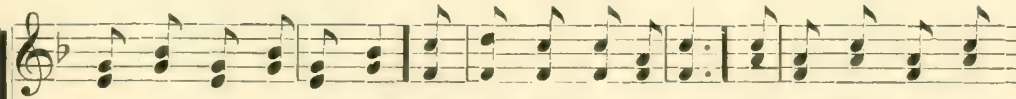

cru - ci - fied my Saviour, An' nailed Him to de cross, Dey cru-ci - fied my

Jo-seph begged His body, An' laid it in de tomb, Oh Joseph begged His

an - gel came from heaven, An' roll de stone a-way, De an - gel came from cold grave could not hold Him, Nor death's cold iron band, De cold grave could not

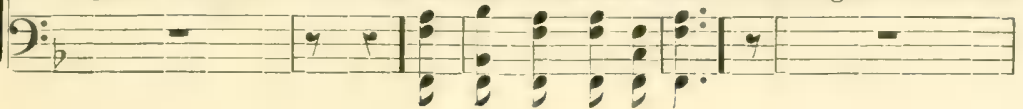


四ust an' Astes.-Continued.

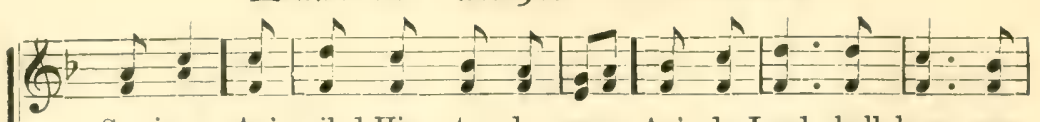

Sav-iour, An' nailed Him to de cross, An' de Lord shall bear my bo - dy, An' laid it in de tomb, $A n^{\prime}$ de Lord shall bear, \&c. heb-ben, An' roll de stone a - way, An' de Lord shall bear, \&c. hold Him, Nor death's cold i - ron band, An' de Lord shall bear, \&c.

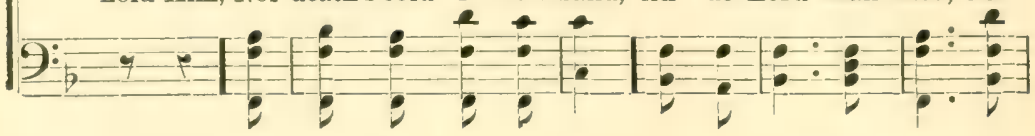
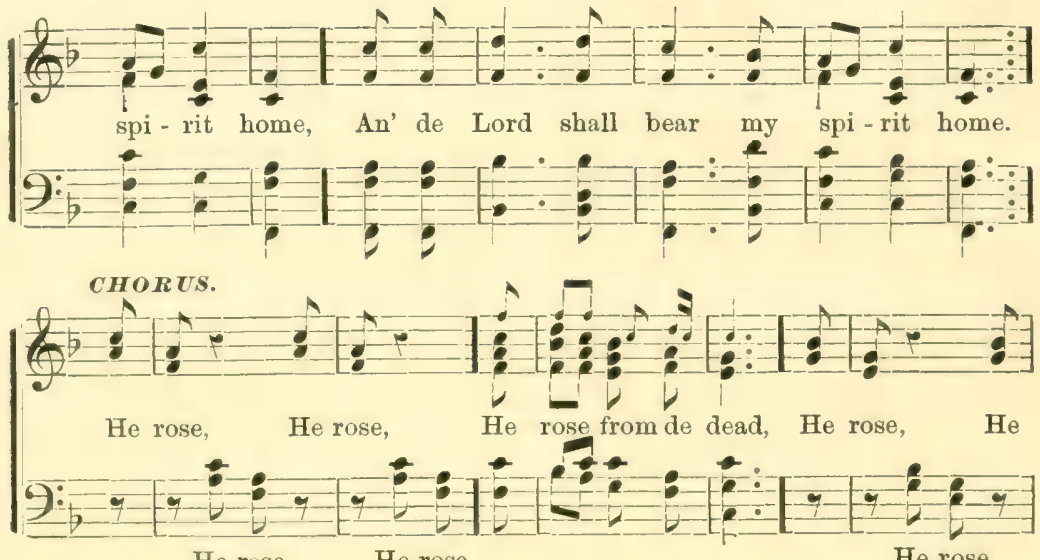

He rose,

He rose,

He rose,
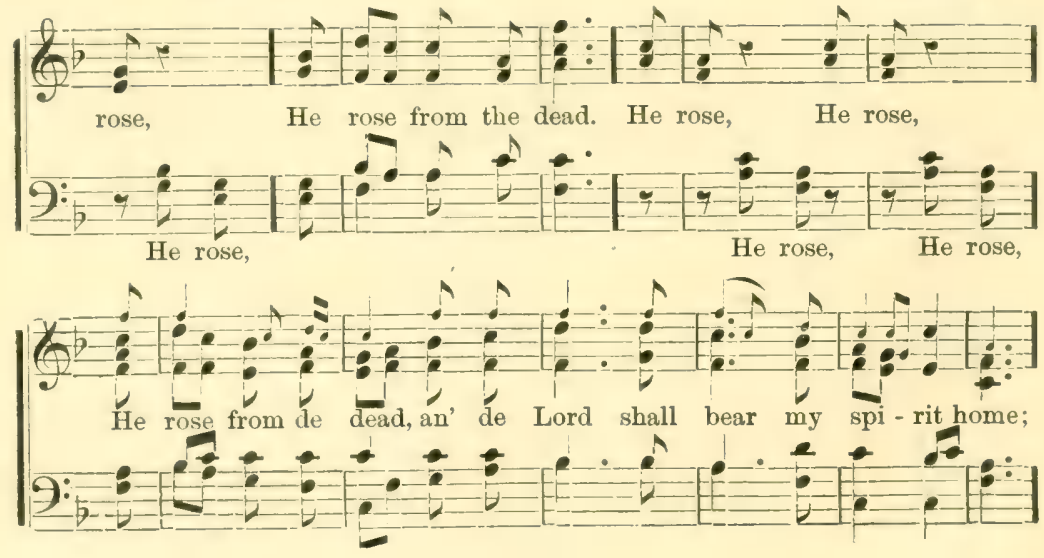
IDust an' Ashes.-Continued.

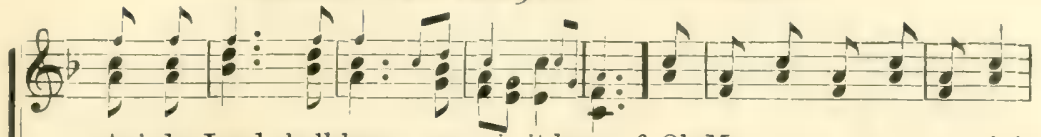

An' de Lord shall bear my spir-it home. 6. Oh Ma - ry came a- run-nin',

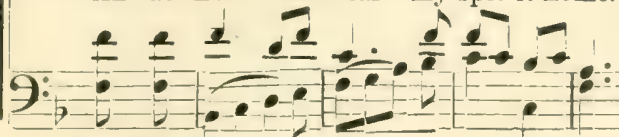

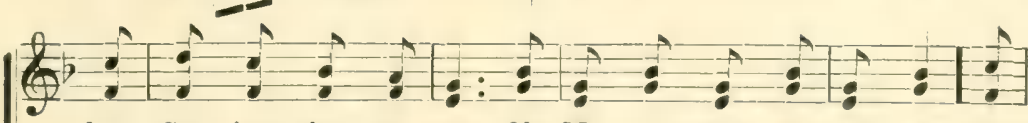

her Sav-iour for to see, Oh Ma - ry came a - run-nin', Her

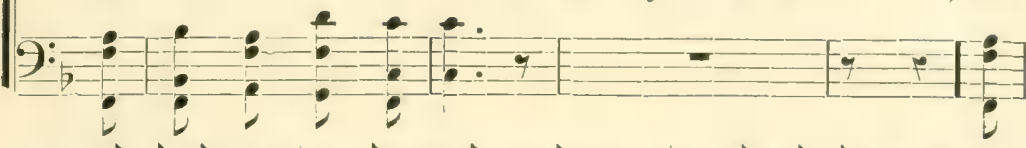

(6)

Saviour for to see, Oh Mary came a - run-nin, Her Saviour for to see,

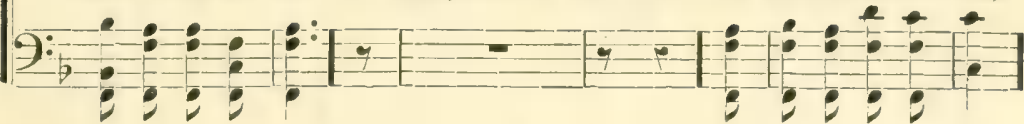

(a)

$A n^{\prime}$ de Lord shall bear my spir-it home, An' de Lord shall bear my spirit home.

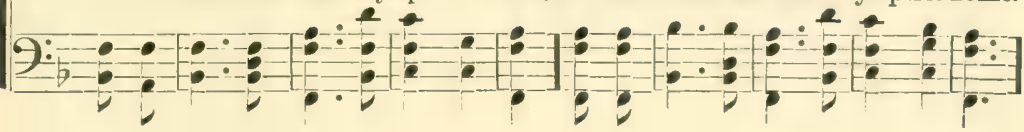

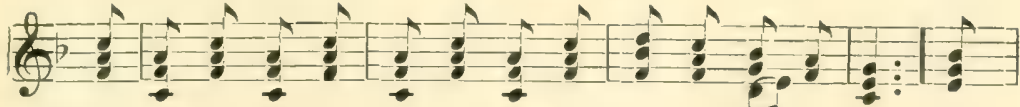

7. De an-gel say $\mathrm{He}$ is not here, He's gone to Gal-i-lee, De

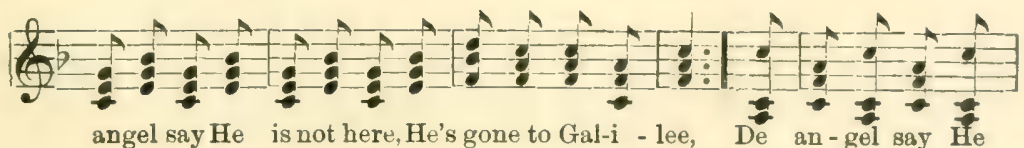


刃⿴囗十

(G)

is not here, He's gone to Gal - i - lee. An' de Lord shall bear my

spir - it home, An' de Lord shall bear my spir - it home.

De an - gel say $\mathrm{He}_{\mathrm{e}}$ is not here. He's gone to Gal - - lee,

$9:-2 \div$

(9):-

De an - gel say $\mathrm{He}$ is not here, He's gone to Gil - i - lee,

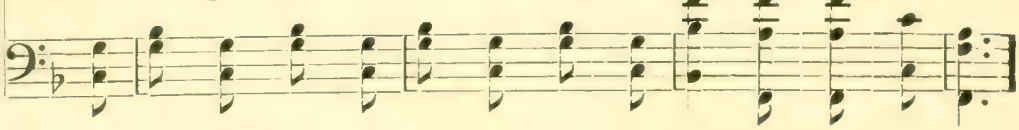

(ब2,

De an - gel say $\mathrm{He}$ is not here, He's gone to Gal - i - lee,

$9:=2$

(6)

An' de Lord shall bear my spir - it home, An' de Lord shall

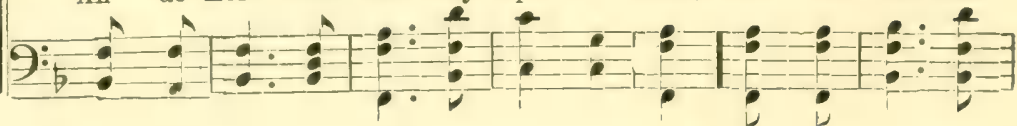


דust an' Asthes.-Concluded.

CHORUS.

(9)

bear my spir - it home. $\mathrm{He}$ rose, $\mathrm{He}$ rose,

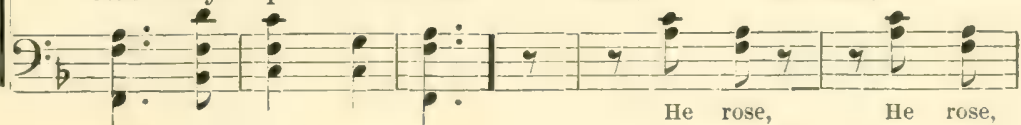

rese from de dead, He rose, He rose,

(9):

$\mathrm{He}$ rose from de dead, $\mathrm{He}$ rose, $\mathrm{He}$ rose,

$9:=\frac{\mathrm{He} \text { rose, }}{\mathrm{He}}$

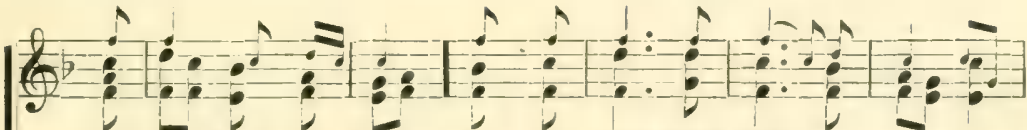
He rose from de dead, An' de Lord shall bear my spir - it

$9:=0 \div \div \div-2+2+2$

(6)

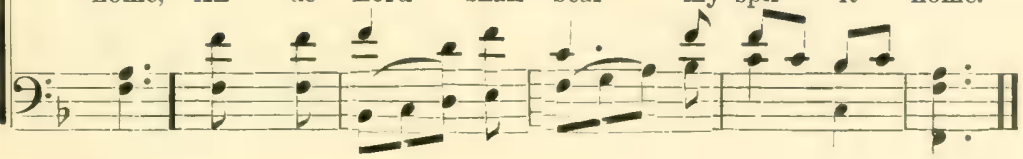




\section{Stars in the Jelements.}
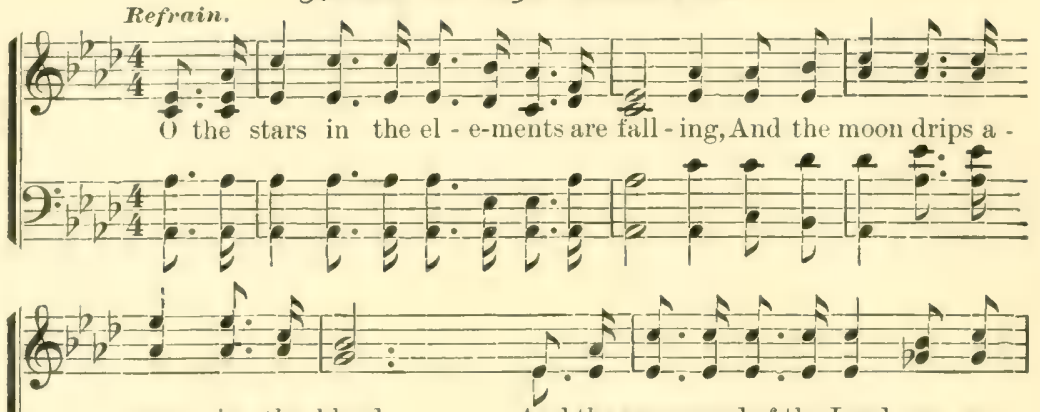

way in the blood,

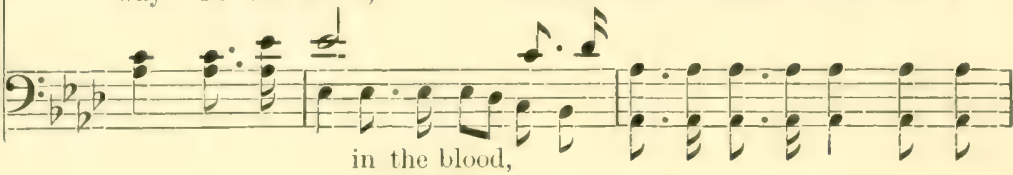

in the blood,

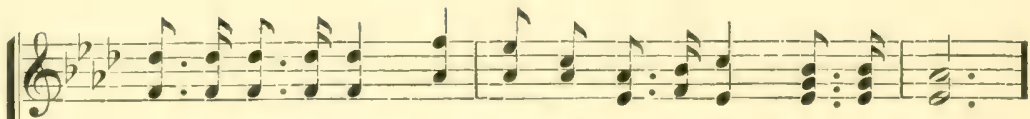

turn-ing home to God. o bless-ed is the name of the Lord!

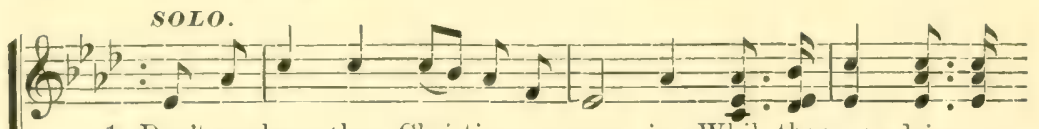

1. Don't you hear those Christians a - pray - ing, While the moon drips a -

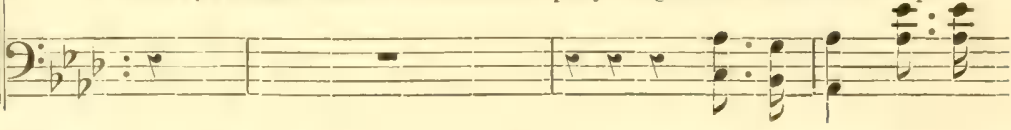

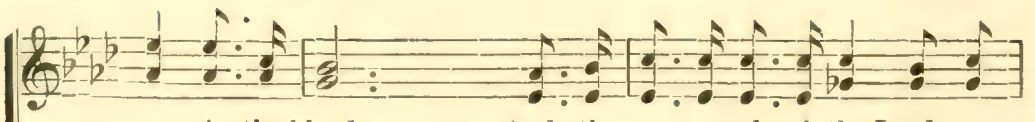

way in the blood,

And the ran-somed of the Lord are

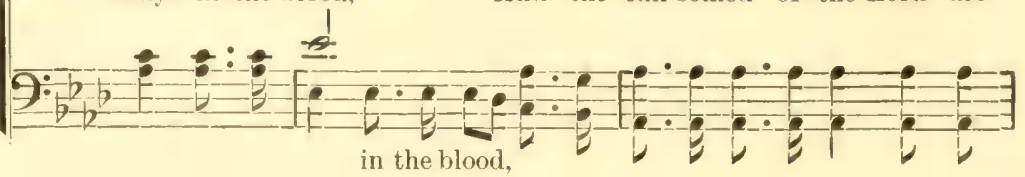




\section{Stars in the Jelrments.-Concluded.}

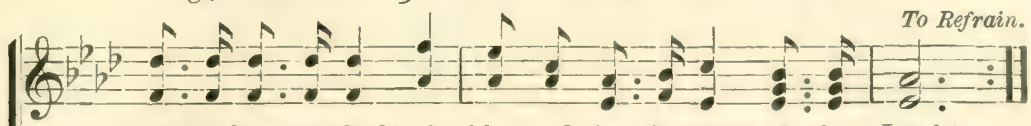

turning home to God? O bless-ed be the name of the Lord!

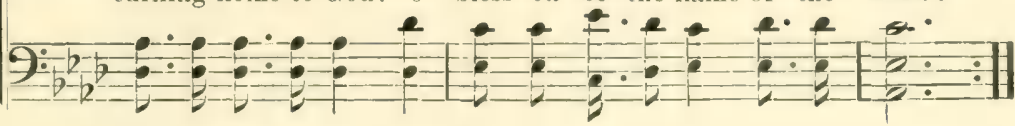

2 Don't you hear those sinners a-screaming,

While the moon drips away, ete.

3 Don't you hear those sinners a-crying,

While the moon drips away, ete.

\section{Ole Styip of Zion.}

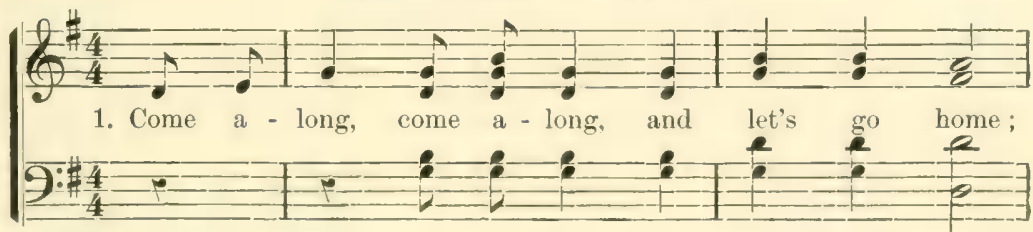

\section{CHORUS.}

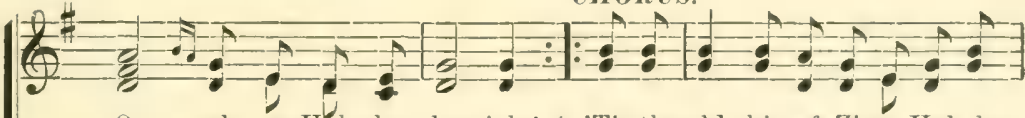

o glo-ry Haj - le - lu - jah! 1. 'Tis the old ship of Zion, Hal - le
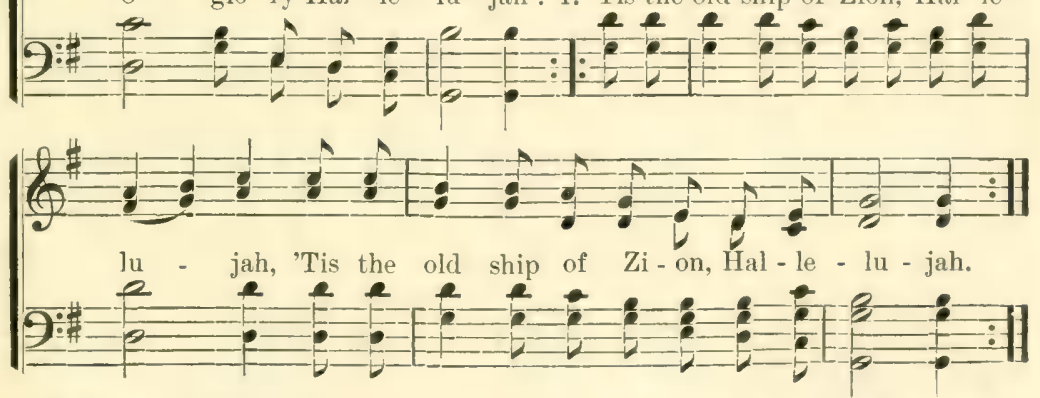

20 what ship is this

That will take us all home?

O glory Hallelujah !-Cho.

3 She has landed many thousand, And she'll land as many a more. O glory Hallelujah ! - Cho.
4 Do you think she will be able For to take us all home?

O glory Hallelujah !-Cho.

50 yes, she will be able

For to take us all home.

$\mathrm{O}$ glory Hallelujah !-Cho. 

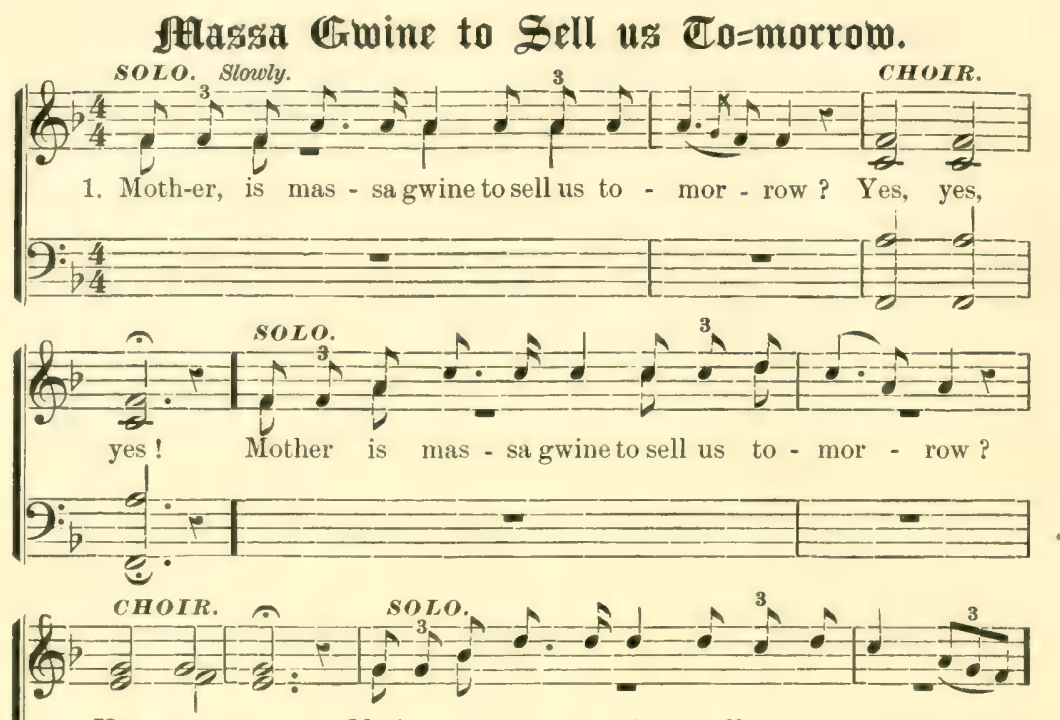

Yes, yes, yes! Mother, is mas - sa gwine to sell us to-mor - row?
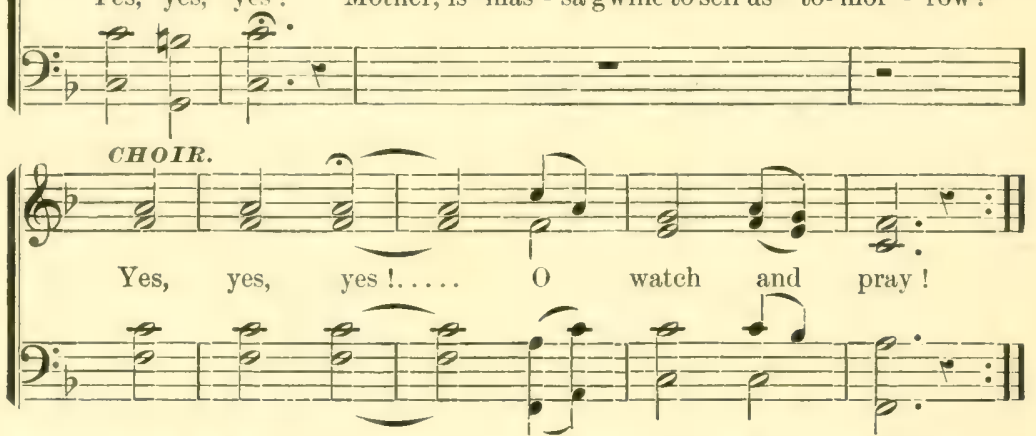

2 Gwine to sell us down in Georgia? Yes, yes, yes !

Gwine to sell us down in Georgia? Yes, yes, yes!

Gwine to sell us way down in Georgia? Yes, yes, yes!

$O$ watch and pray!

3 Farewell, mother, I must lebe you. Yes, yes, yes !

Farewell, mother, I must lebe you. Yes, yes, yes !

Farewell, mother, I must lebe you.

Yes, yes, yes !

0 watch and pray !
4 Mother, don't griebe arter me.

$$
\text { No, no, no ! }
$$

Mother, don't griebe arter me. No, no, no!

Mother, don't griebe arter me. No, no, no!

o watch and pray!

5 Mother, I'll meet you in heaven. Yes, my child!

Mother, I'll meet you in heaven. Yes, my child !

Mother, I'll meet you in heaven. Yes, my child !

$\mathrm{O}$ watch and pray ! 


\section{Grlory and 3lanor.}

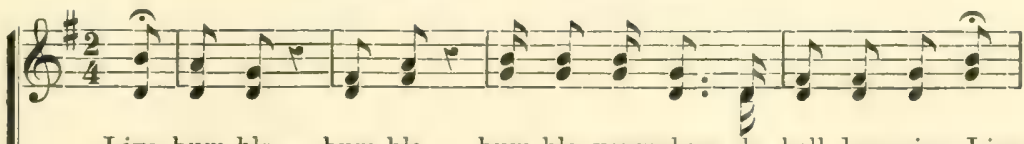

Live hum-ble, hum-ble, hum-ble yourselves, de bell done ring, Live
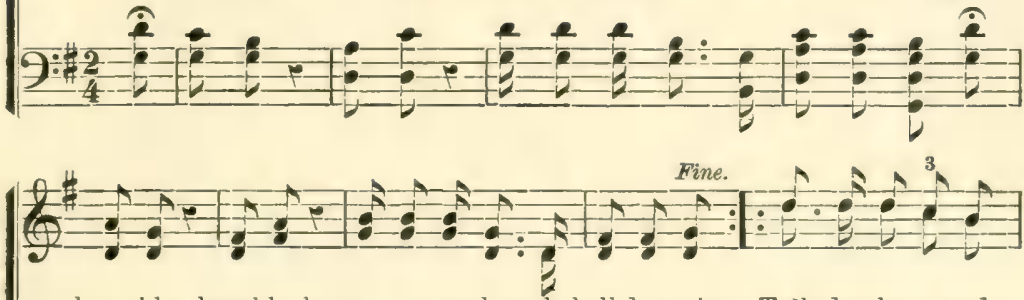

hum-ble, humble, humble yourselves, de bell done ring. Talk de glo-ry and
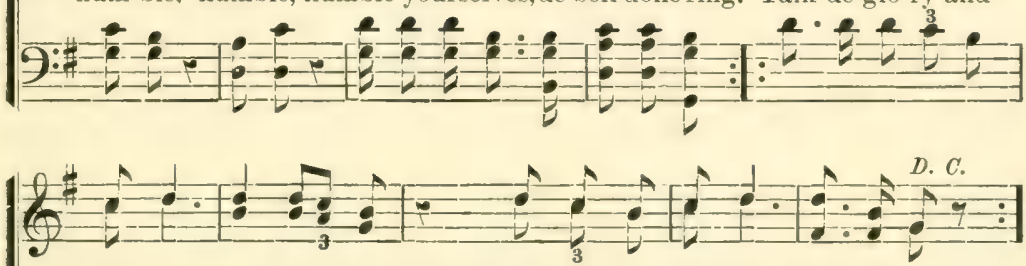

hon - or, Praise Je - sus, Talk de glo- ry and hon - or, Praise de Laın'!

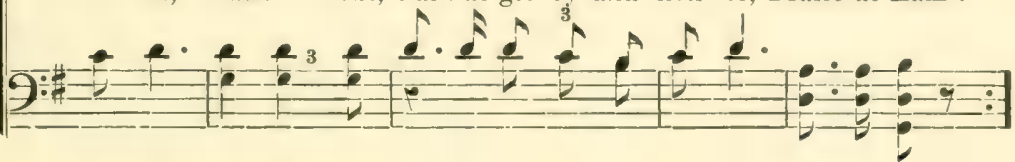

SOLO. (To be suug rapidly in one tone.)

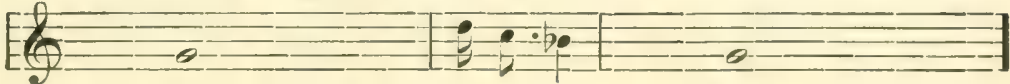

1. Oh, my young Christians, $\quad$ (for ye shall be judged, false

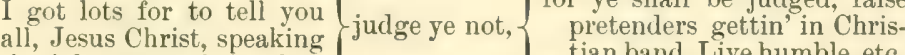
thro' de organ of the clay, $($ tian band. Live humble, etc.

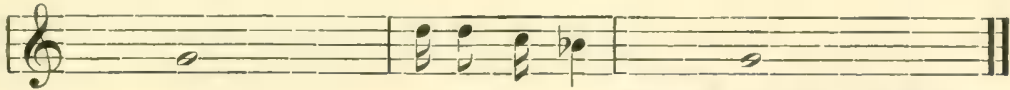

(When God goin' to call dem children from de distant land. one day, one day, $\{$ Tombstones cra'king, graves back, In his heart like one day, one day, $\quad$ bustin', hell and the seas gwine a raving wolf,....... t' give up their dead. live humble, etc. 


\section{国eter on the Sea.}

1st Sopranos \& Altos.

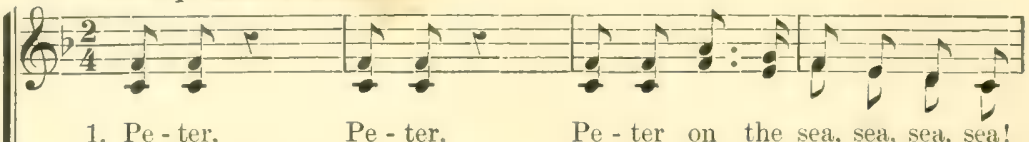

2d Sopranos \& Altos.

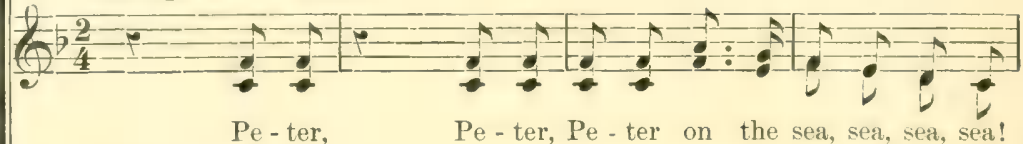

1st Brases \& Tcnors.

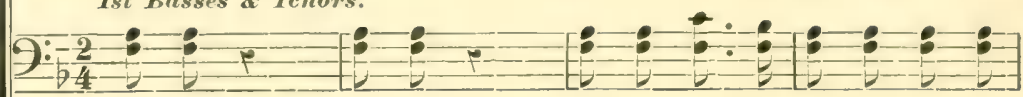

Pe-ter, Pe-ter, Pe-ter on the sea, sea, sea, sea!

2d Basses \& Tenors.

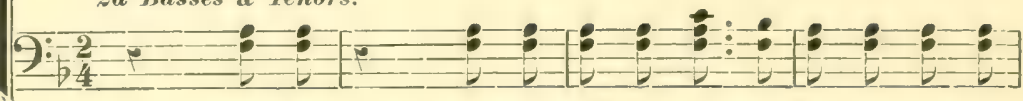

$\mathrm{Pe}-\mathrm{ter}$,

Pe-ter, Pe-ter on the sea, sea, sea, sea!

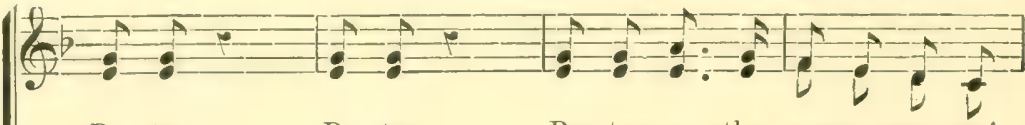

Pe-ter, Pe-ter, Pe-ter on the sea, sea, sea, sea!

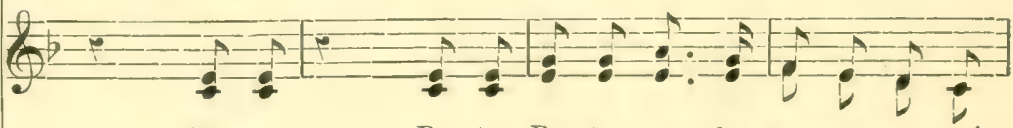

$\mathrm{Pe}$ - ter

$\mathrm{Pe}$ - ter, Pe-ter on the sea, sea, sea, sea!
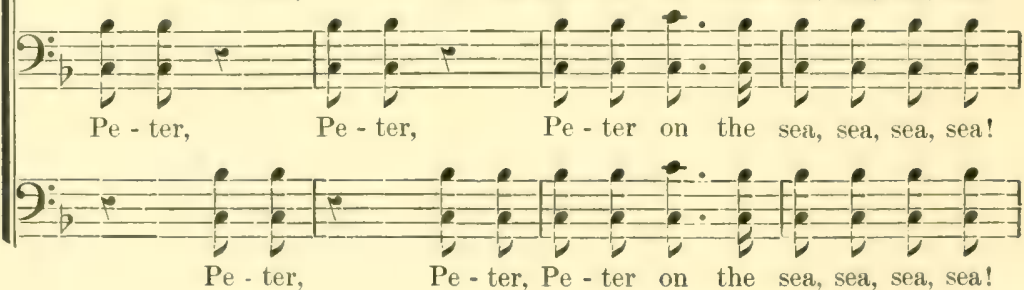

$2 \|:$ :Gabriel, Gabriel, Gabriel blow your trump, trump, trump, trump! : :\| Gabriel blow your trumpet, Gabriel blow your trumpet loud!

$3 \|:$ :Daniel, Daniel, Daniel in the lions', lions', ::\|

Daniel in the lions', Daniel in the lions' den. 


\section{Fater on the Sea.-Concluded.}

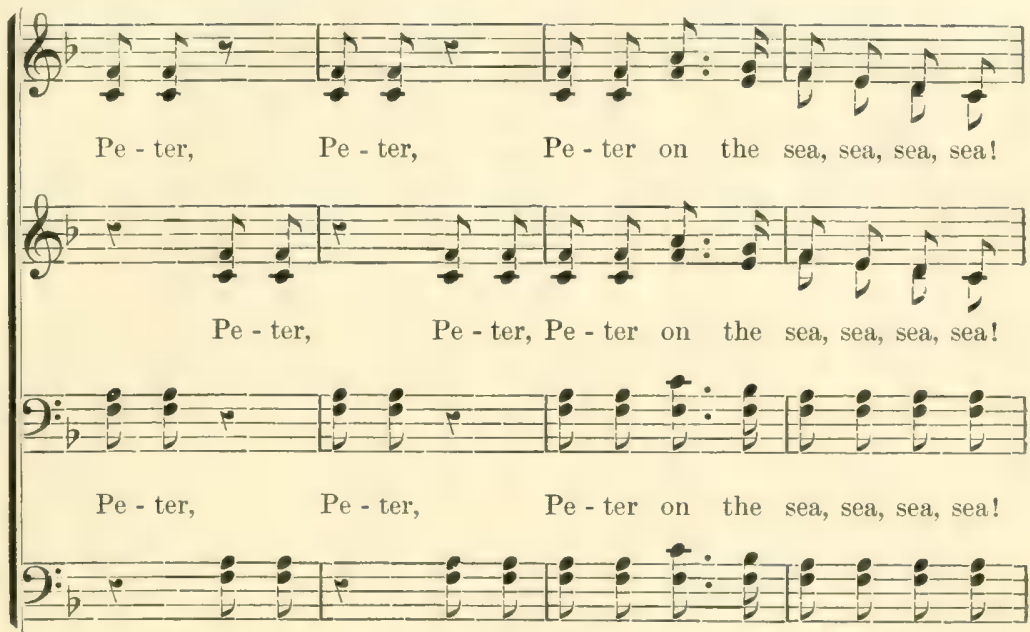

Pe-ter, Pe-ter, Pe-ter on the sea, sea, sea, sea!

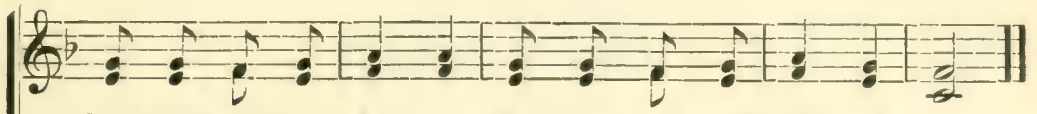

Drop your nets and fol - low, Drop your nets and fol - low me.

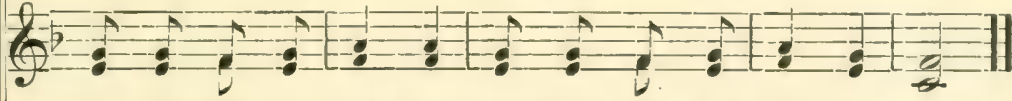

Drop your nets and fol - low, Drop your nets and fol - low me.

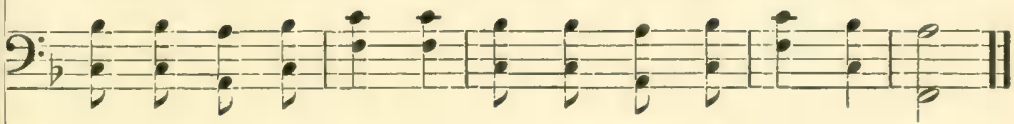

Drop your nets and fol - low, Drop your nets and fol - low me.

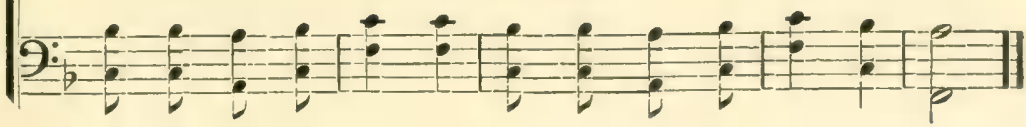

$4 \|:$ : Who did, who did, who did swallow Jonah, Jonah?: :\|

Who did swallow Jonah, who did swallow Jonah whole?

$5 \|:$ : Whale did, whale did, whale did swallow Jonah. Jonah,:: Whale did swallow Jonah, whale did swallow Jonah whole! 


\section{lRough and Rolling Sea.}
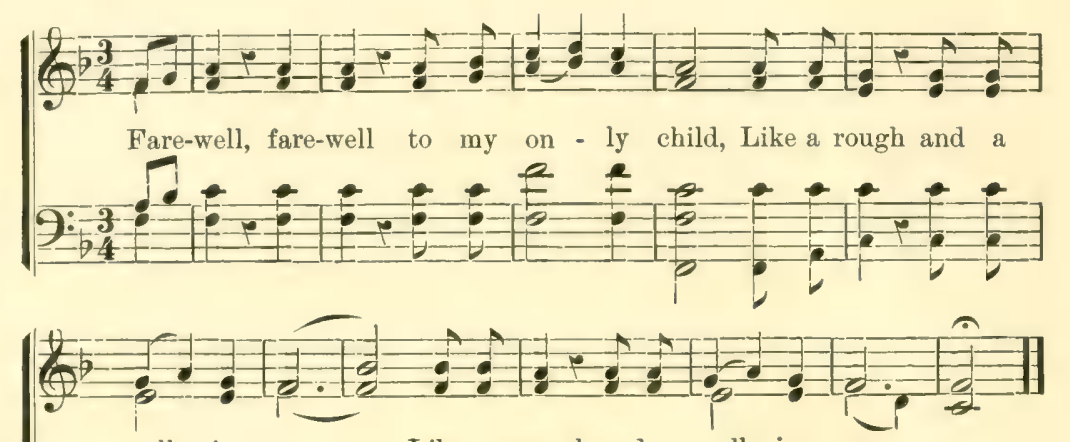

roll - ing sea,.... Like a rough and a roll -ing sea.......

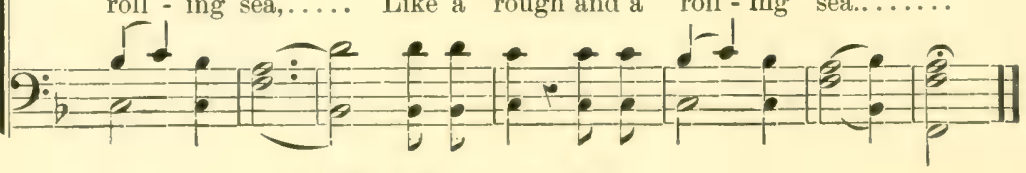

2 The lightnings flashed,

And the thunders rolled,

Like a rough and rolling sea.

is The storms beat high,

And the winds blew fierce,

Like a rough and rolling sea.

\section{Thare ware Trn Virgins.}

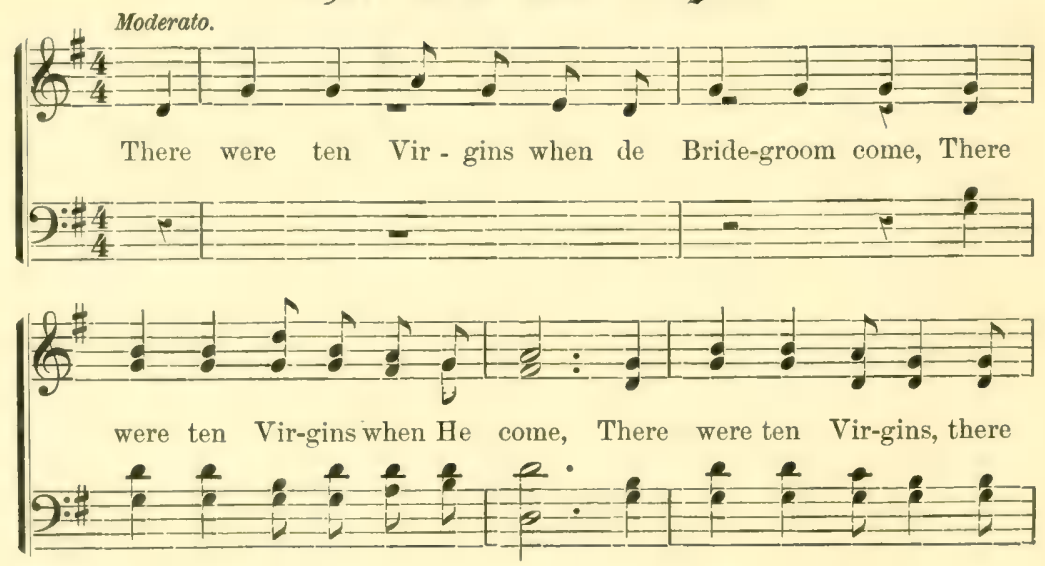


There were Ten Virgins.-Concluded.

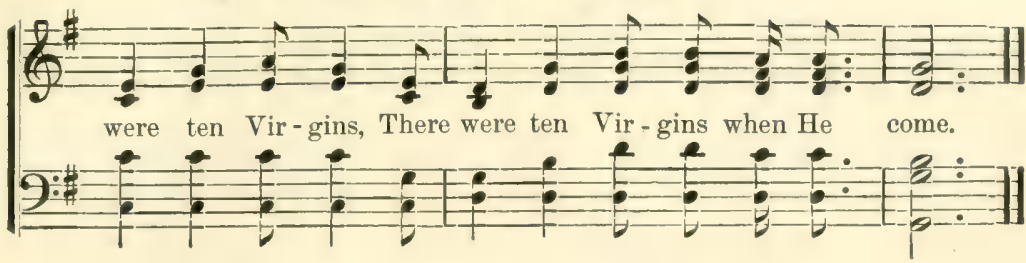

1 And five of them were wise, When, etc.

2 And five of them were foolish, When, etc.

3 And de foolish said to de wise, When, etc.

40 give us of your oil, When, etc.

5 And de wise said to de foolish, When, etc.

6 o go to them that sell, When, etc.

7 And buy for yourselves, When, ete.

\section{General lioll call.}

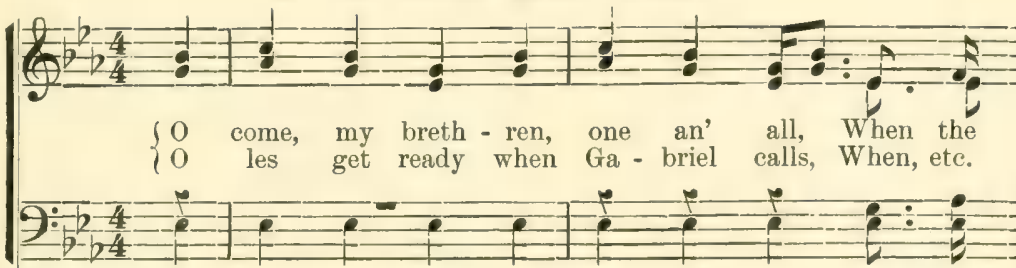

CHORUS.

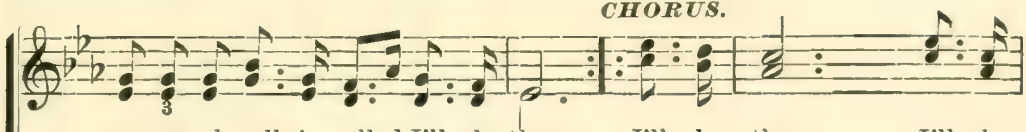

gen-er-al roll is called I'll bethere. I'll be there, I'll be
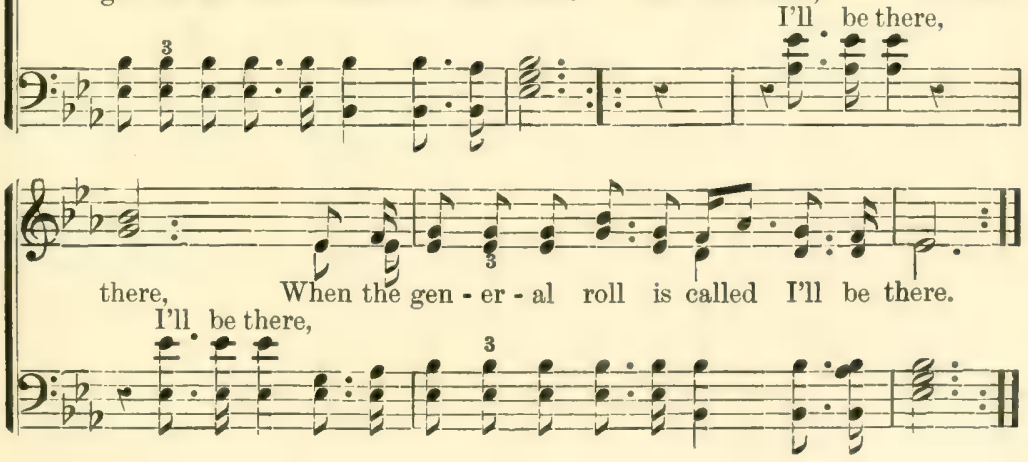


\section{Going to zescanen.}
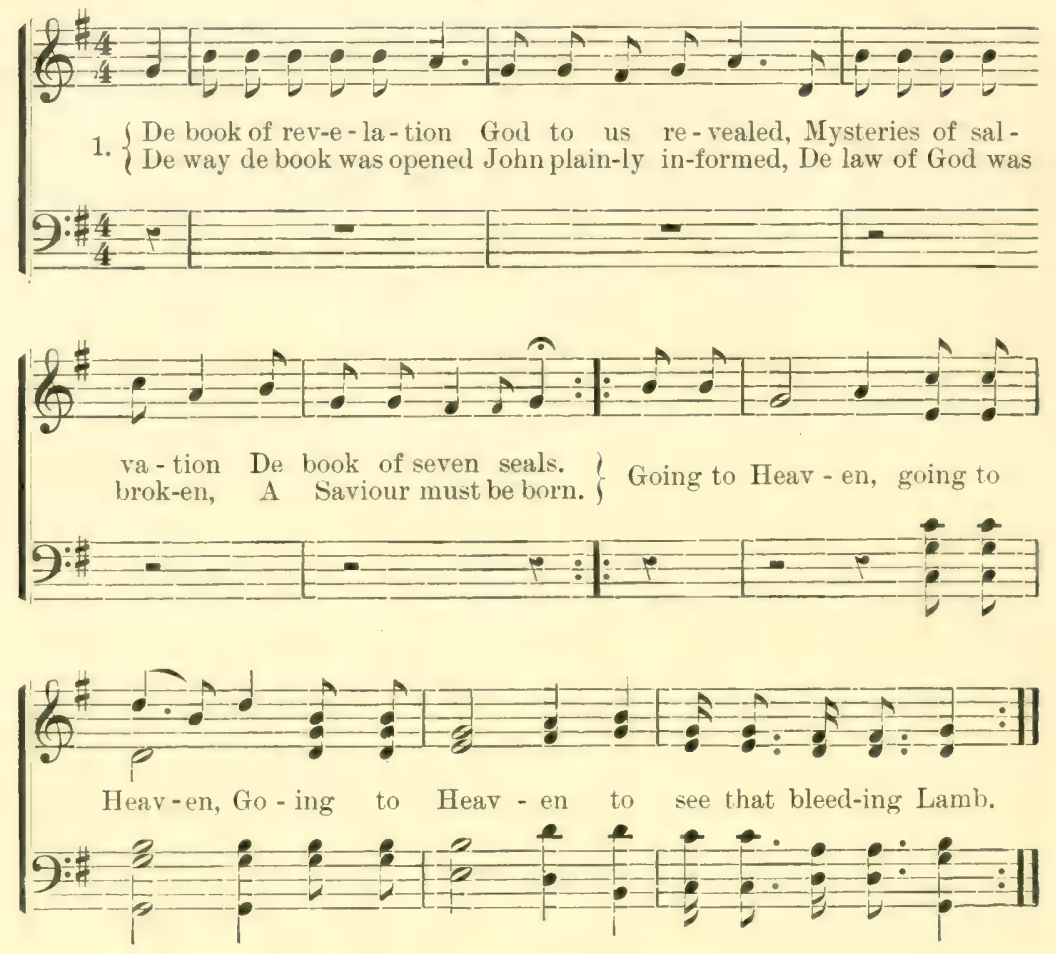

2 John saw de Heavens open,

De Conqueror riding down,

He looked and saw white horses ; And rider following on.

If you want to know de Conqueror, $\mathrm{He}$ is de word of God,

His eyes are like a burnin' throne, He is de word of God.-Cho.

3 Hossanna to de Prince of Life, Who clothed Himself in clay, And entered de Iron Gate of death, And bore de ties away.

See how de ennqueror mounts aloft, And to His Father flies :

With scars of honor on His flesh, And trials in His eyes.-Cho. 


\section{ffighting On.}

Mrale Voices.-Moderato.

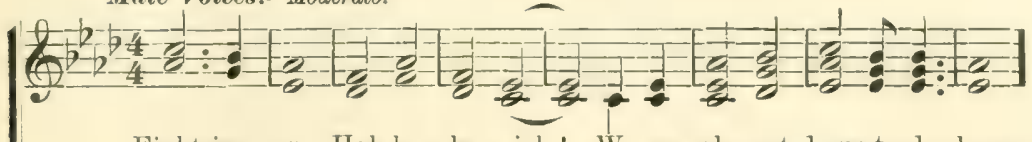

Fight-ing on, Hal-le - lu - jah! We are al-most down to de shore.

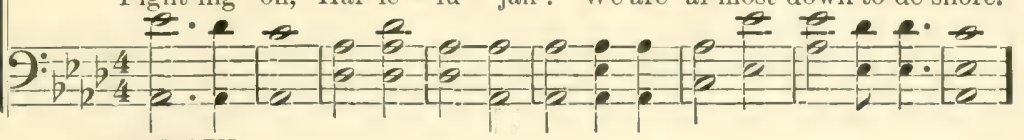

REFRAIN.

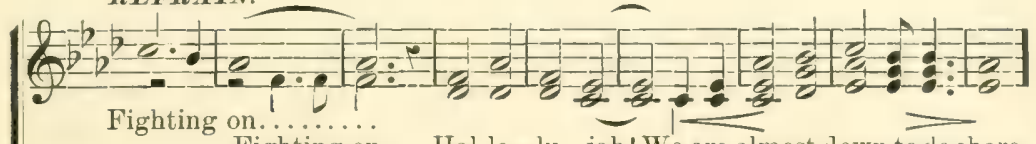

Fighting on, Hal-le - lu - jah! We are almost down to de shore.

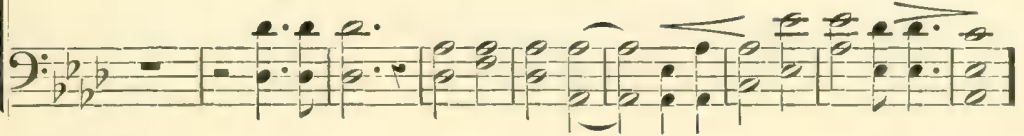

SOLO.

1. Hal-le-lu-jah to the Lamb, Je-sus died for eb-ry man.? We are
2. In my room right by my bed, Jesus take me when I'm dead.\} WHOR.

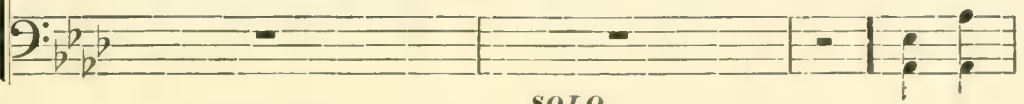

SOLO.

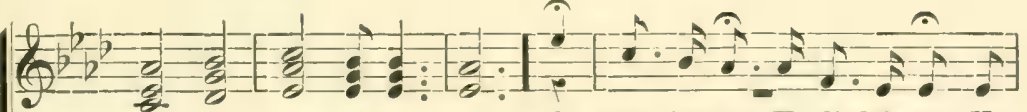

al - most down to de shore, $\mathrm{He}$ died for you, $\mathrm{He}$ died for me, $\mathrm{He}$ e 2

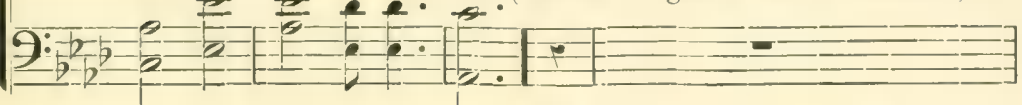

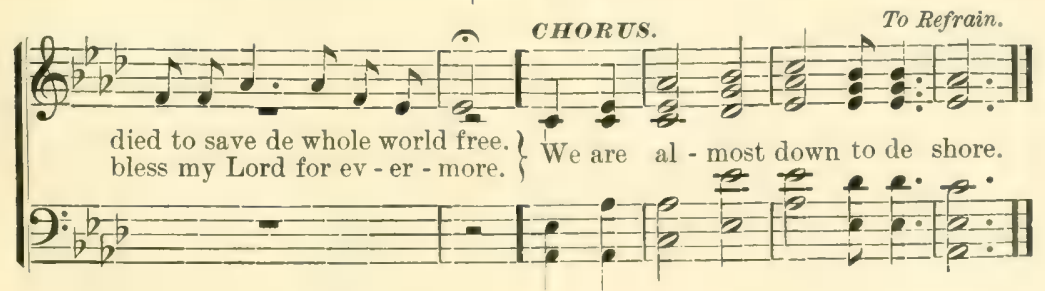




\section{fi'm a =laolling.*}

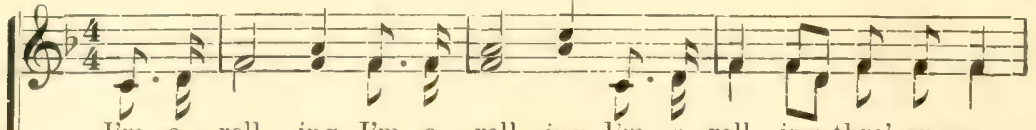

I'm a - roll - ing, I'm a - roll - ing, l'm a-roll - ing thro' an un -
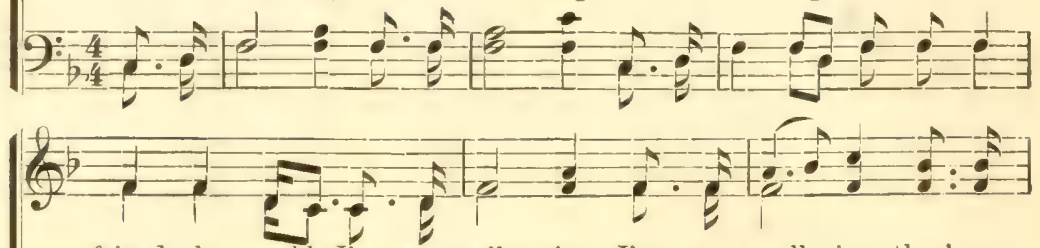

friend-ly world; I'm a - roll - ing, I'm a - roll-ing thro' un
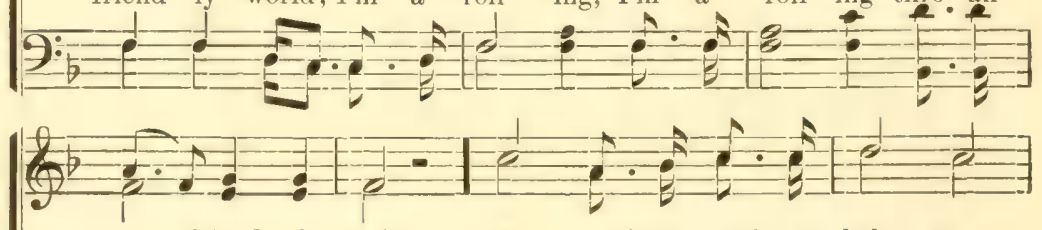

un - friend - ly world. 1. O brothers, won't you help me,

2. 0 sis - ters, won't you help me,

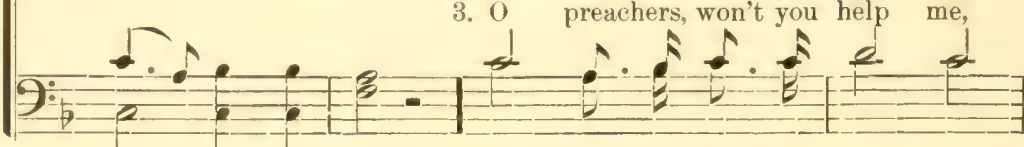

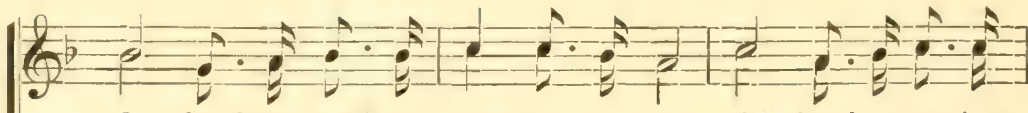

o broth-ers, won't you help me to pray ? O brothers, won't you

O sis - ters, won't you help me to pray? O sis - ters, etc.

O preachers, won't you help me to fight? O preachers, etc.
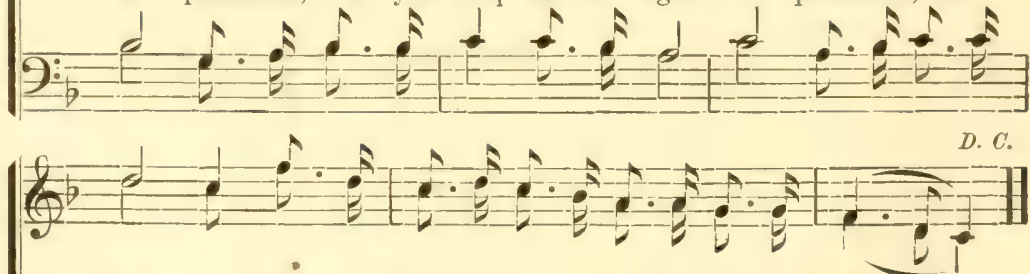

help me, Won't you help me in the service of the Lord?

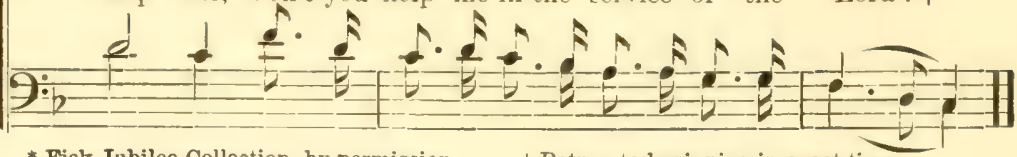

* Fisk Jubilee Collection, by permission. + Return to beginning in exact time. 


\section{I'm a=trab'ling to the Grane.*}

CHORES.

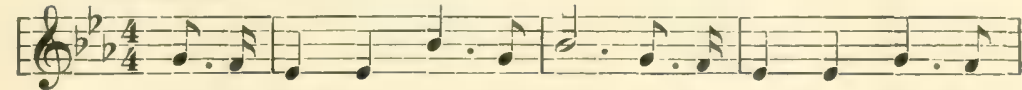

I'm a - trav'ling to the grave, I'm a - trav'ling to the

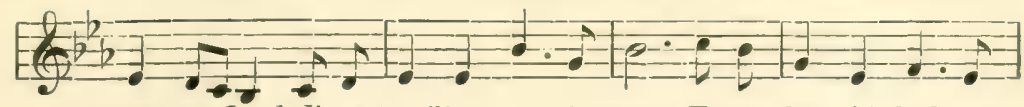

grave, my Lord, I'm a-trav'ling to the grave, For to lay this bod - y

Fine.

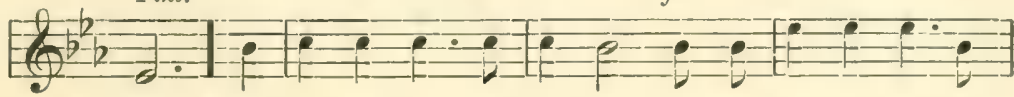

down. 1. My Mas - sa died a - shouting, Singing glo - ry hal-le-

D. C.

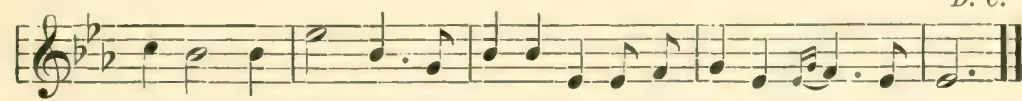

Iu - jah, The last words he said to me, Was a-bout Je - ru - sa - lem.

2 My missis died a-shouting, ete.

$3 \mathrm{My}$ brother died a-shouting, etc.

$4 \mathrm{My}$ sister died a-shouting, etc.

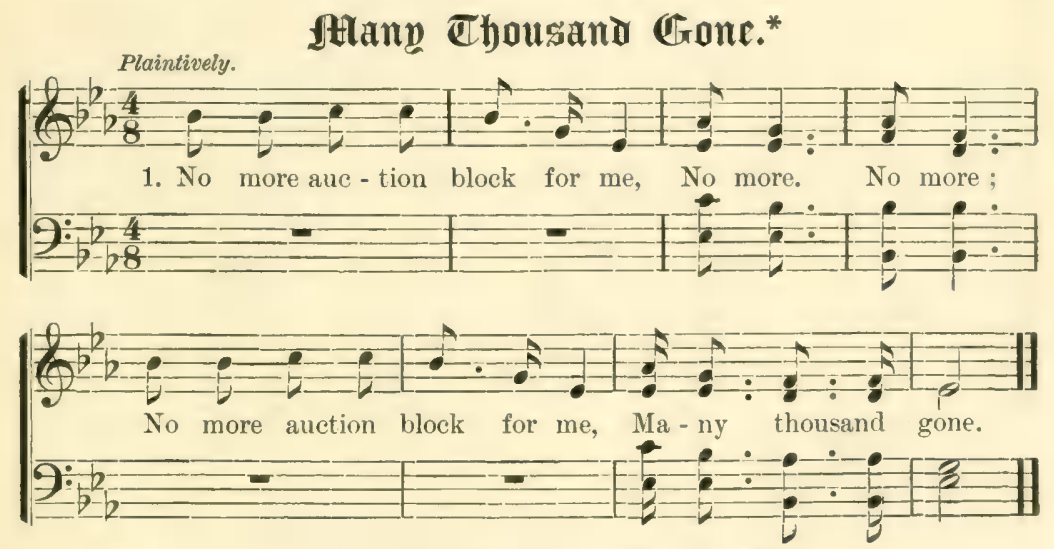

2 No more peck o' corn for me, etc.

3 No more driver's lash for me, etc.

4 No more pint o' salt for me, etc.

5 No more hundred lash for me, etc.

6 No more mistress' call for me, etc.

* Fisk Jubilee Coliection, hy permiseion. 


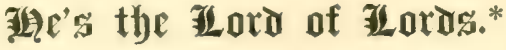
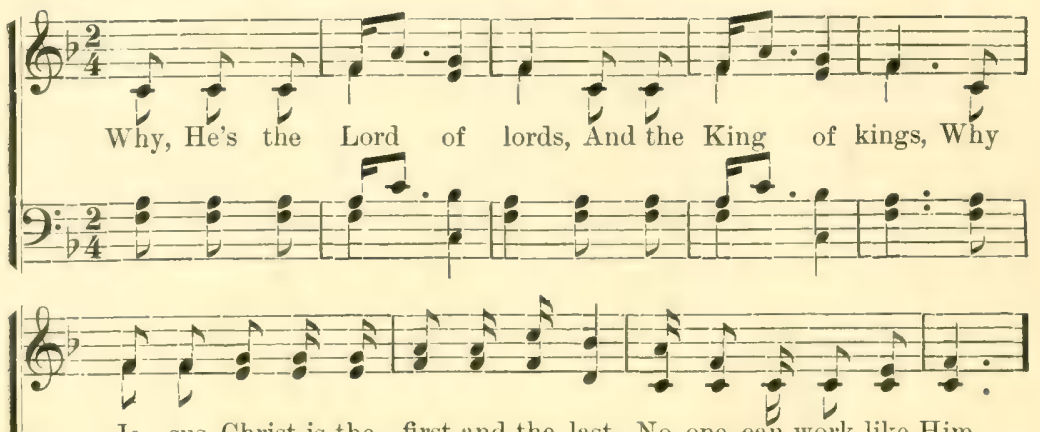

Je - sus Christ is the first and the last, No one can work like Him.
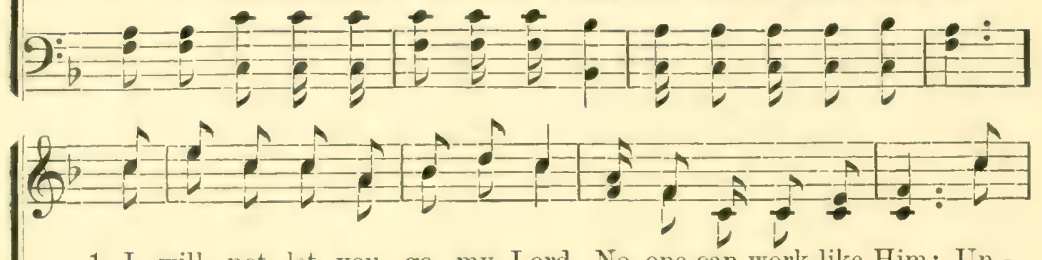

1. I will not let you go, my Lord, No one can work like Him; Un -
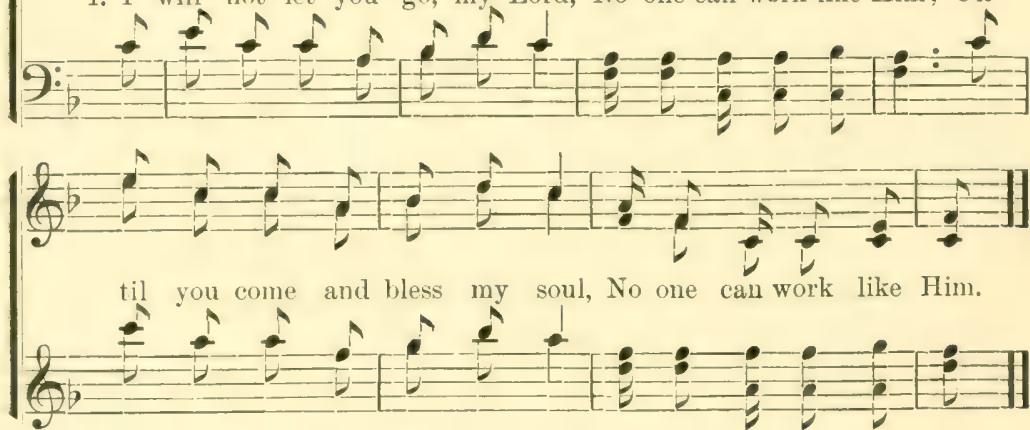

2 For Paul and Silas bound in jail, No one can work like Him ;

The Christians prayed both night and day, No one can work like Him ; Cho.-Why, He's the Lord of lords, etc.

3 I wish those mourners would believe, No one can work like Him,

That Jesus is ready to receive,

No one can work like Him.

Cho.-Why, He's the Lord of lords, etc.

* Fisk Jubilee Collection, by permission. 


\section{fty detay's Uloum.*}

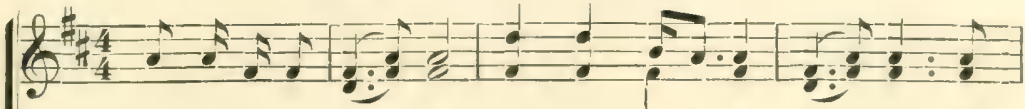

Oh ! breth-er-en, my way, my way's cloud - y, my way, Go
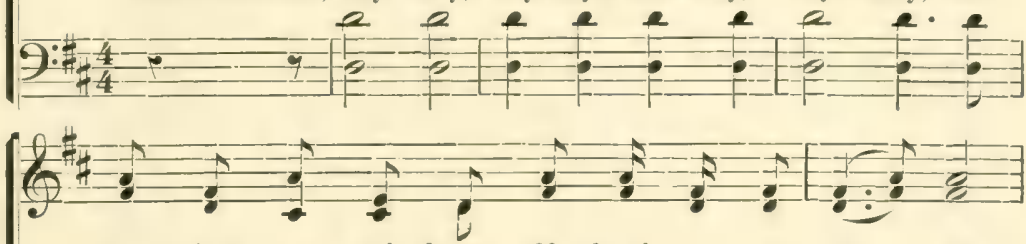

send them an - gels down, Oh! breth-er - en, my way,
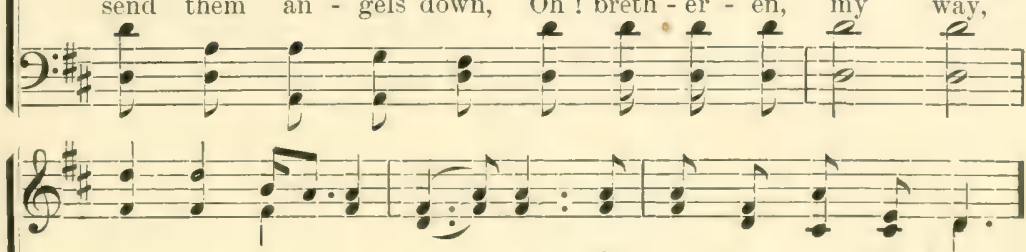

my way'scloud-y, my way, Go send them an - gels down.
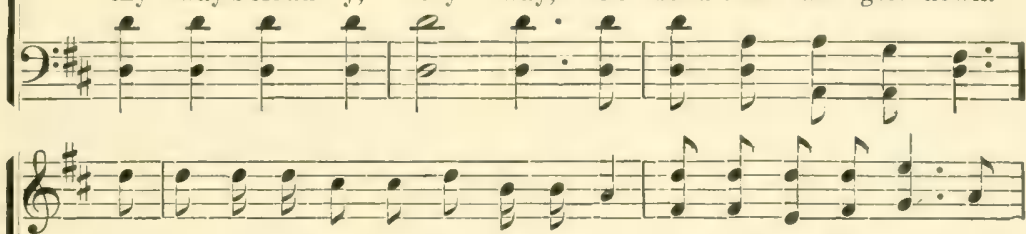

1. There's fire in the east and fire in the west, Send them angels down, And

2. Old Sa-tan's mad, and I am glad, Send them angels down, He

3. I'll tell you now as I told you be-fore, Send them angels down, To

4. This is the year of Ju - bi - lee, Send them angels down, The
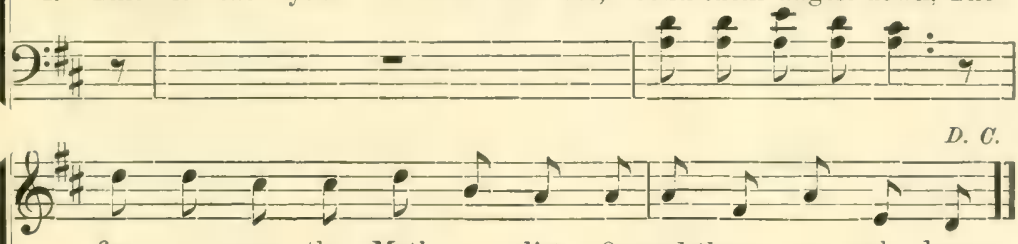

fire a-mong the Meth - o - dist, $O$ send them an - gels down. missed the soul he thought he had, $O$ send them an-gels down. the promised land I'm bound to go, $O$ send them an - gels down.

Lord has come to set us free, $O$ send them an-gels down.

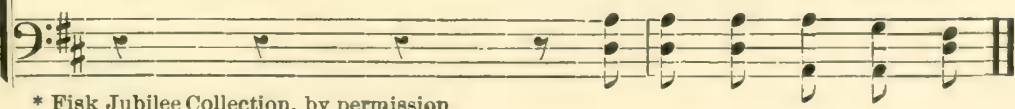




\section{ftly zord's lioing all the Time.*}

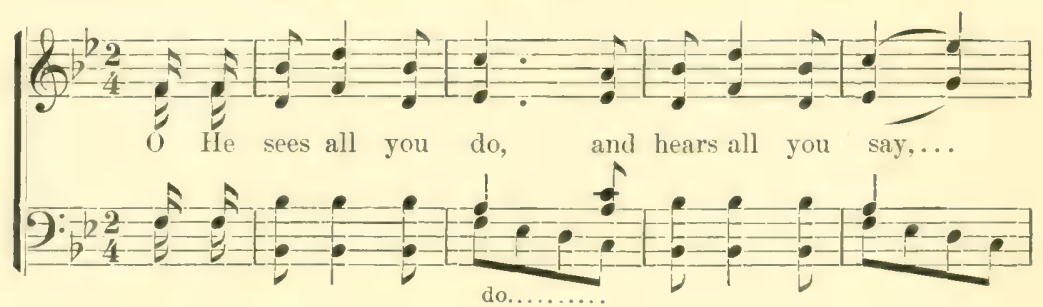

SOLO.

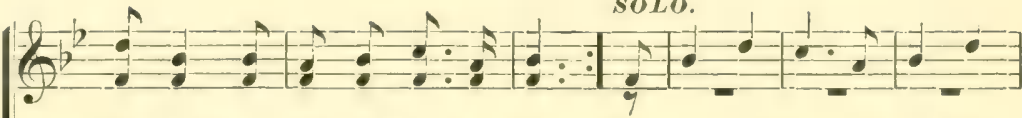

My Lord's a - rid-ing all the time. When I was down in Egypt's
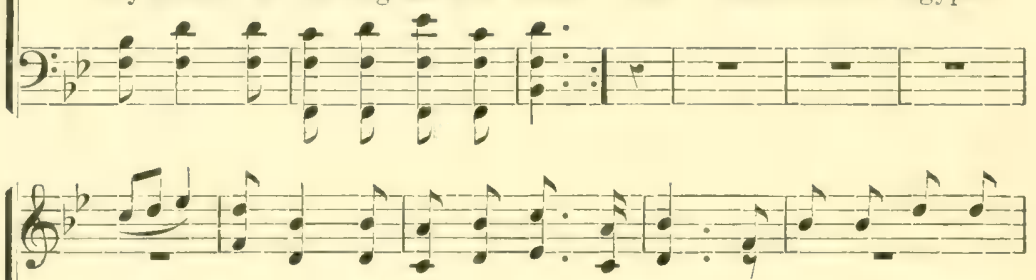

land, My Lord's a - rid - ing all the time; I heard a might-y
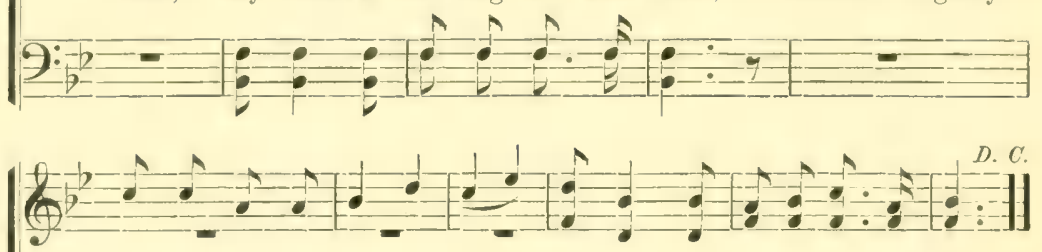

talking 'bout the promis'd land, My Lord's a-riding all the time.

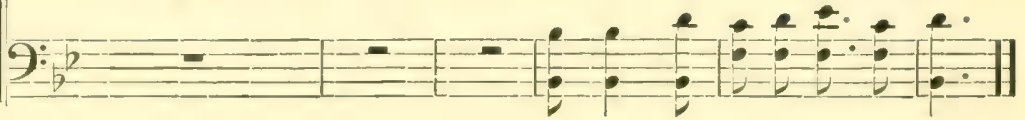

2 Come down, come down, my Lord, come down,

My Lord's a-riding all the time;

And take me up to wear the crown, My Lord's a-riding all the time.

30 sinner, you had better pray,

My Lord's a riding all the time;

It looks like judgment ebery day,

My Lord's a-riding all the time.

* Fisk Jubilee Collection, by permission. 


\section{Fige fes Jing of Jings.}

CHORUs.

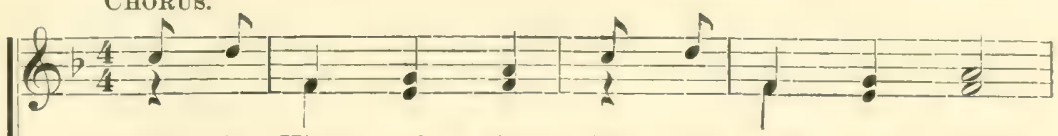

1. He is King of kings, $\mathrm{He}$ is Lord of lords.

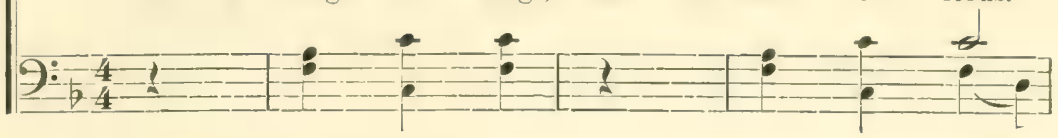

Fine.

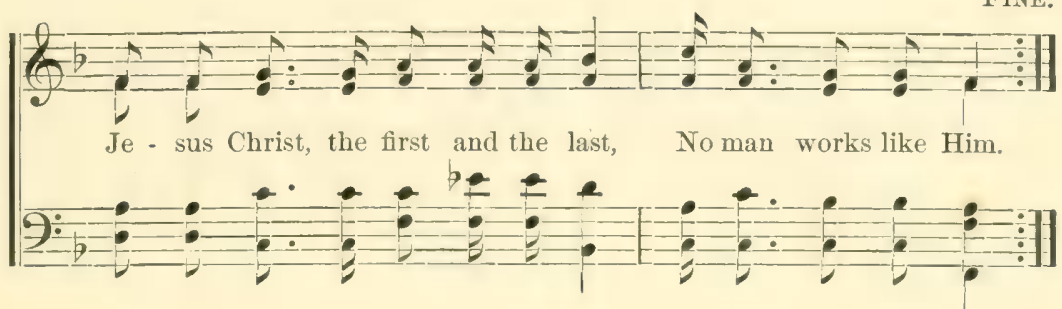

Solo.

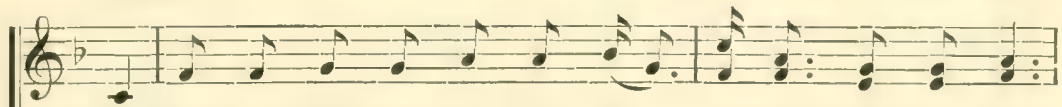

1. He built a plat-form in the air, No man works like Him;

2. He pitched a tent on $\mathrm{Ca}$-naan's ground, No man works like Him;

3. I know that my Re-deem - er lives, No man works like Him;

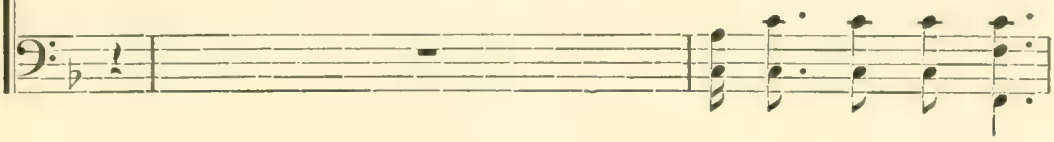

D. C.

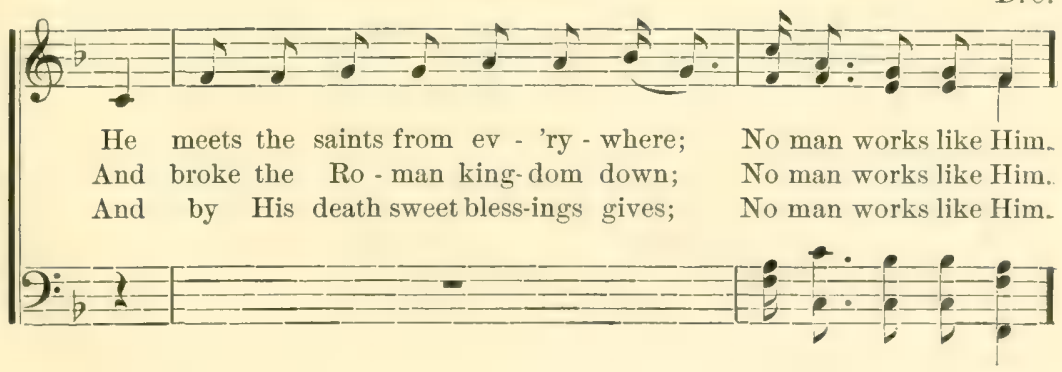




\section{Zlittle bathed a=turnin' in my 嗮eart.*}

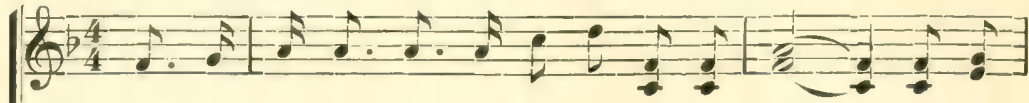

1. Dere's a lit-tle wheel a-turn-in' in my heart, Dere's a
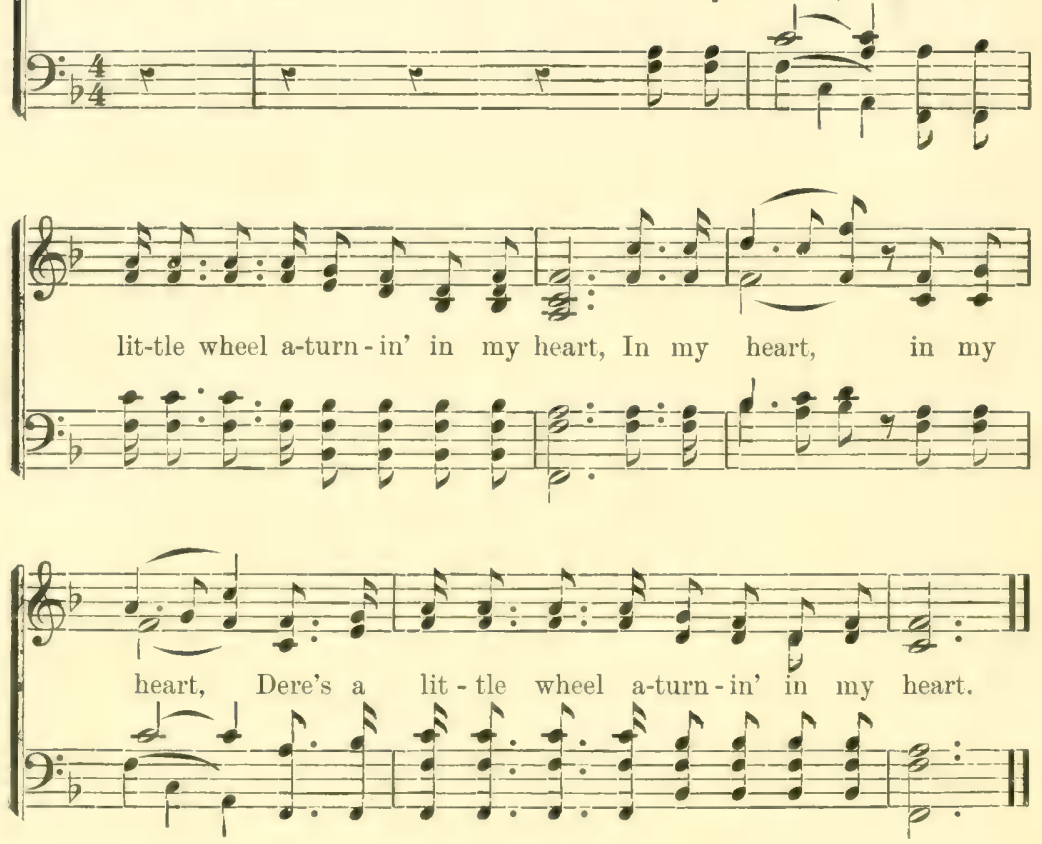

2 ||: O I feel so very happy in my heart, :\| In my heart, in my heart,

O I feel so very happy in my heart.

$3 \|$ : O I don't feel no ways tired in my heart, :\| In my heart, in my heart,

O I don't feel no ways tired in my heart.

$4 \|: 0$ I feel like shouting in my heart, :\| In my heart, in my heart,

O I feel like shouting in my heart.

5 || : Iv'e a double 'termination in my heart, :\| In my heart, in my heart,

Iv'e a double 'termination in my heart.

* From Tuskegee Collection, by permission. 


\section{Serk and $Y_{e}$ shall ffind.**}

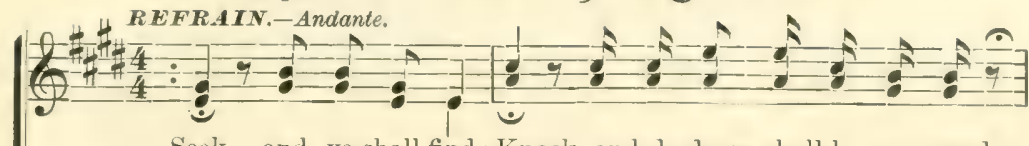

Seek, and ye shall find; Knock, and de door shall be 0 -pened;
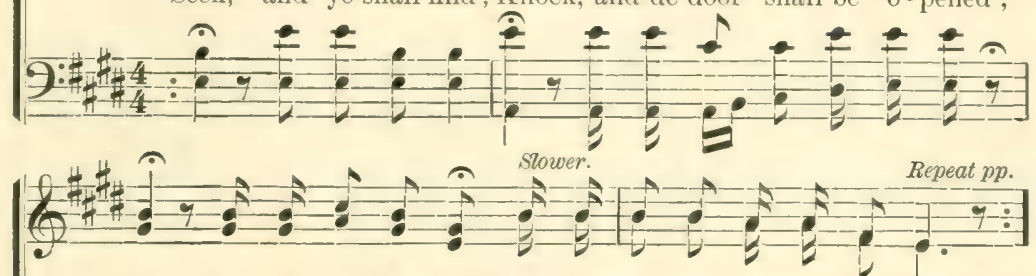

Ask and it shall be giv'n, And de Love come a-trickaling down.
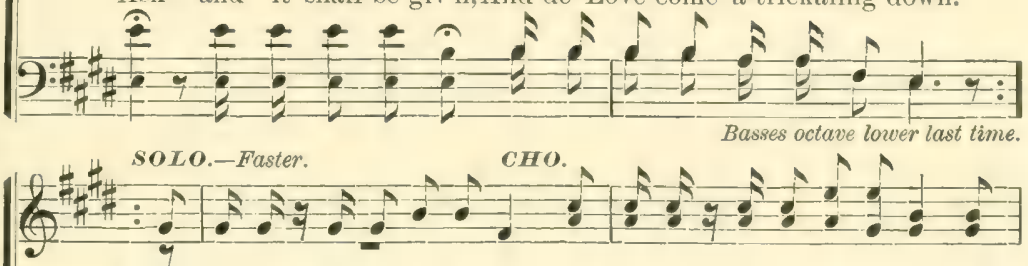

1. $\{$ My brother, de Lord has been here, My brother, de Lord has been here, My 1. \{ My sis-ter, de Lord has been here, My sis-ter, de Lord has been here.My
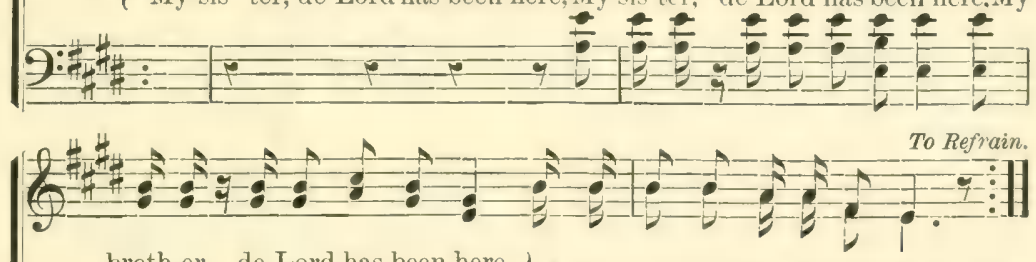

broth-er, de Lord has been here,
sis-ter, de Lord has been here, And de Love come a-trickaling down.

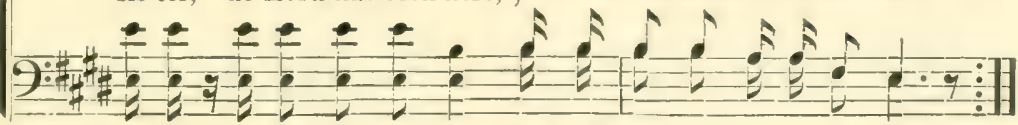

$2 \|::$ Elder, de Lord has been here, ::\|

And de Love come a-trickaling down.

$\|::$ Deacon, de Lord has been here,: :\|

And de Love come a-trickaling down.

Seek, and ye shail find, etc.

$3 \|:$ :Preacher, de Lord has been here, : :\|

And de Love come a-trickaling down.

$\|::$ Class-leader, de Lord has been here, ::\|

And de Love come a-trickaling down.

Seek, and ye shall find, etc.

*From Tuskegee Collection, by permission. 


\section{retalking in to sLight.*}

REFRAIN.-Moderato.
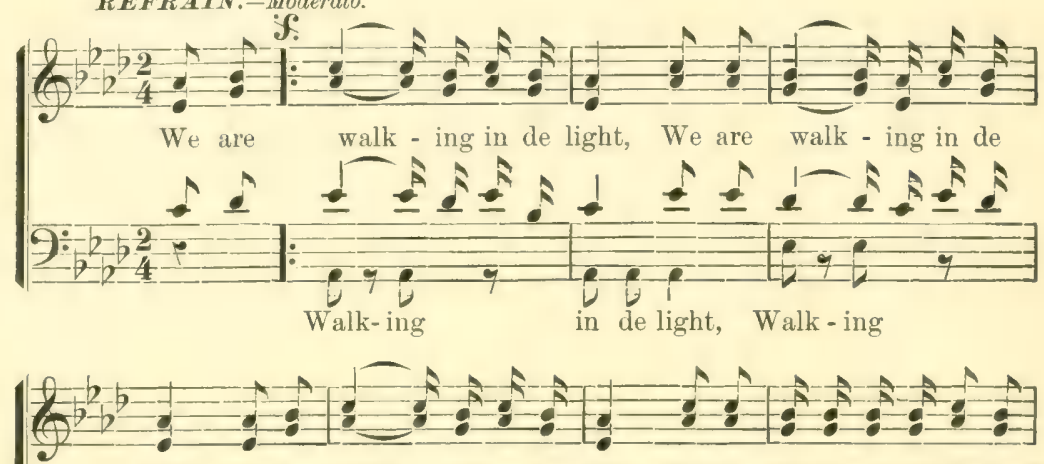

light, We are walk - ing in de light, We are walking in de light of
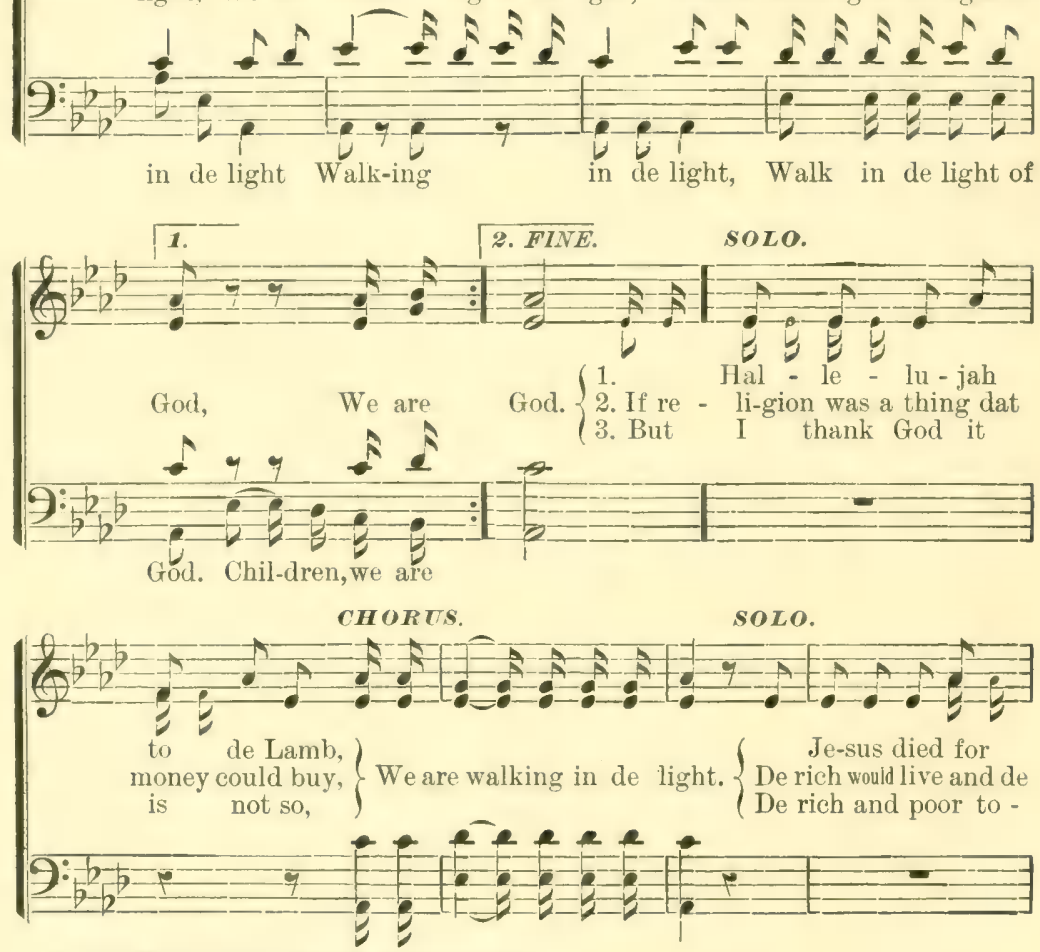

* From Tuskegee Collection, by permission. 


\section{جatalking in one zingt.-Concluded.}

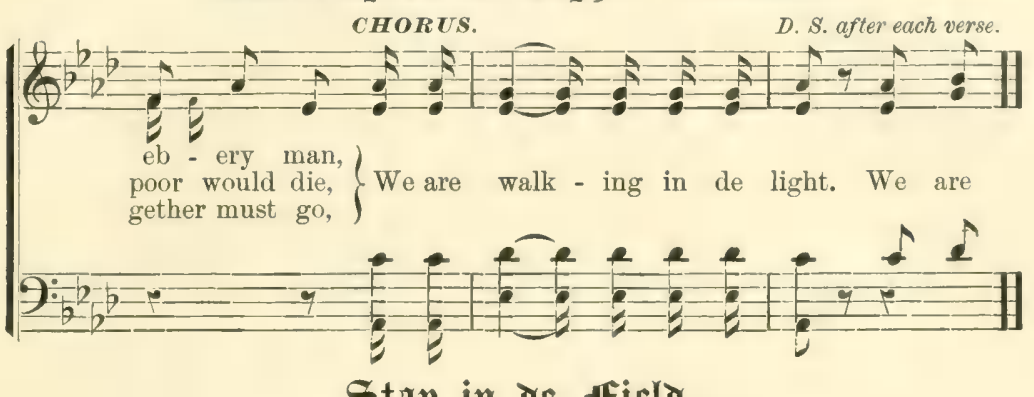

Stap in to field.

REFRAIN.-Moderato.

O war-rior,

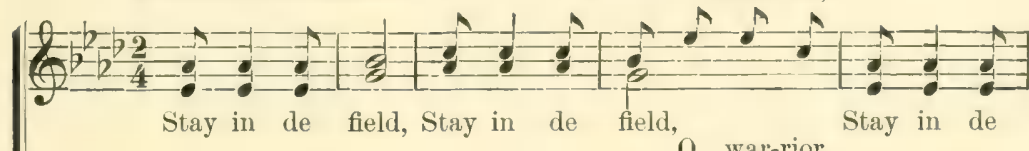

O war-rior,

Stay in de
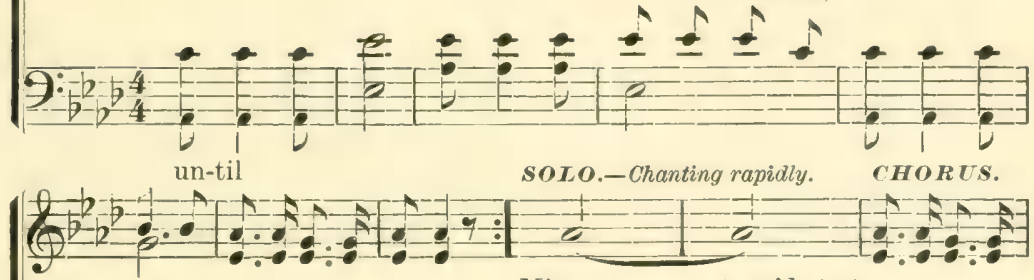

field, 'til dewar is ended. 1. $\left\{\begin{array}{l}\text { Mine eyes are turn'd to } \\ \text { de Hebbenly gate un- }-\end{array}\right.$ til de war is
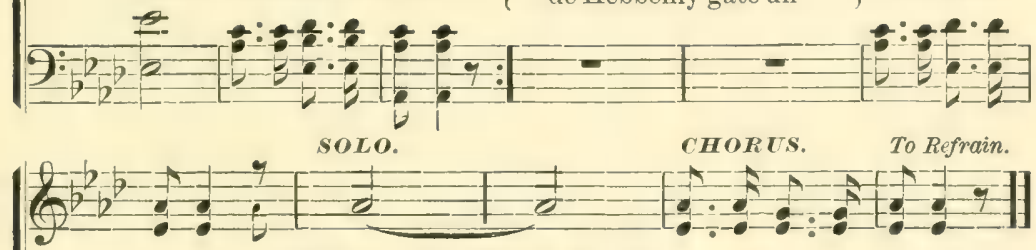

end-ed. I'll $\left\{\begin{array}{c}\text { keep on my way or I'll be } \\ \text { too late, un }-{ }_{-}\end{array}\right\}$til de war is end-ed.

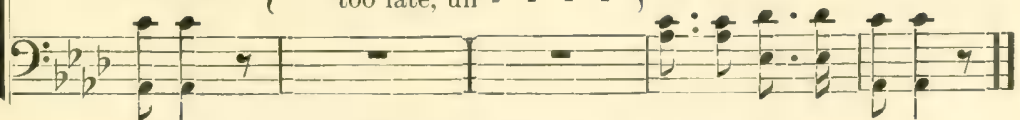

2 De tallest tree in Paradise, until de war is ended,

De Christian call de Tree of Life, until de war is ended.-Ref.

3 Green trees burning, why not de dry? until de war is ended, My Saviour died, why not I ? until de war is ended.-Ref. 


\section{F'll be thare in the ftlorming.*}

Refrain.-Moderato.

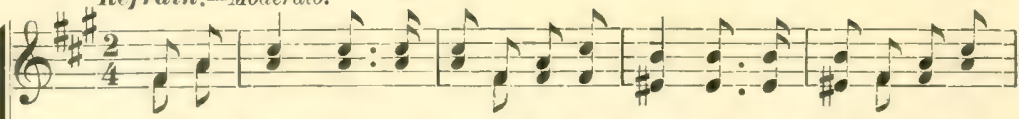

I'll be there in the morning, I'll be there in the morning, I'll be
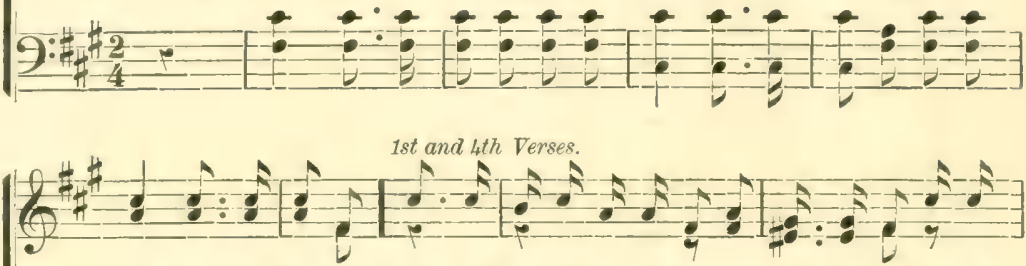

there in the morning. When the gen'ral roll is called, Yes, I'll be there; When the
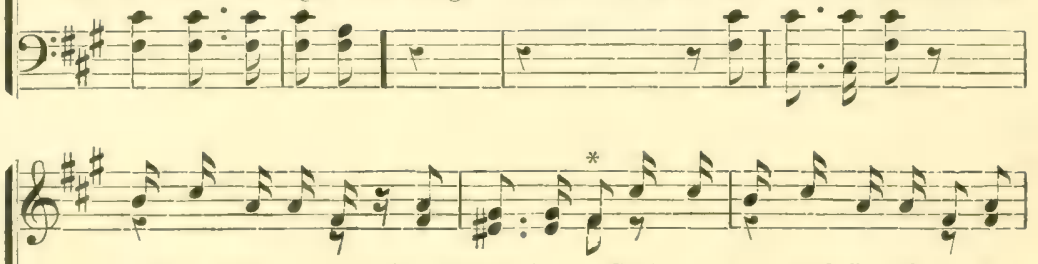

gen-'ral roll is called,Yes, I'll be there; Gwine to pray with Hezekiah, Yes,
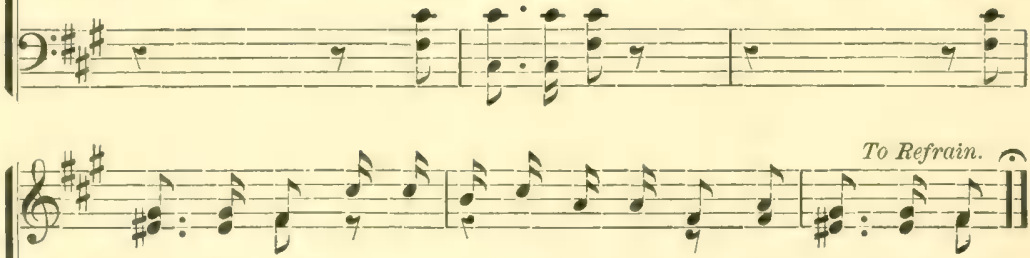

I'll be there; Gwine to sing with Jer-e - miah, Yes, I'll be there.

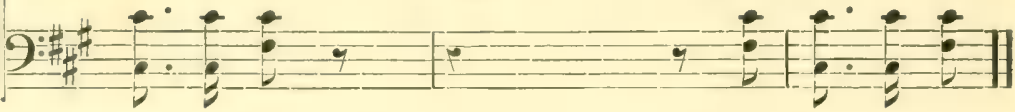

2 When the gen'ral roll is called, Yes, I'll be there ;

Gwine to sing around the throne, Yes, I'll be there.

Gwine to pray around the throne, Yes, I'll be there ;

Gwine to wear a white robe,

Yes. I'll be there.
3 When the gen'ral roll is called, Yes, I'll be there ;

Gwine to see my Massa Jesus, Yes, I'll be there.

Gwine to wear a starry crown, Yes, I'll be there :

Gwine to live for evermore, Yes, I'll be there.

* End at this note the last verse.

* From Tuskegee Collection, by permission. 


\section{Ser $y \mathfrak{f} \mathfrak{o}^{\prime}$ an' Twenty Jelders.}
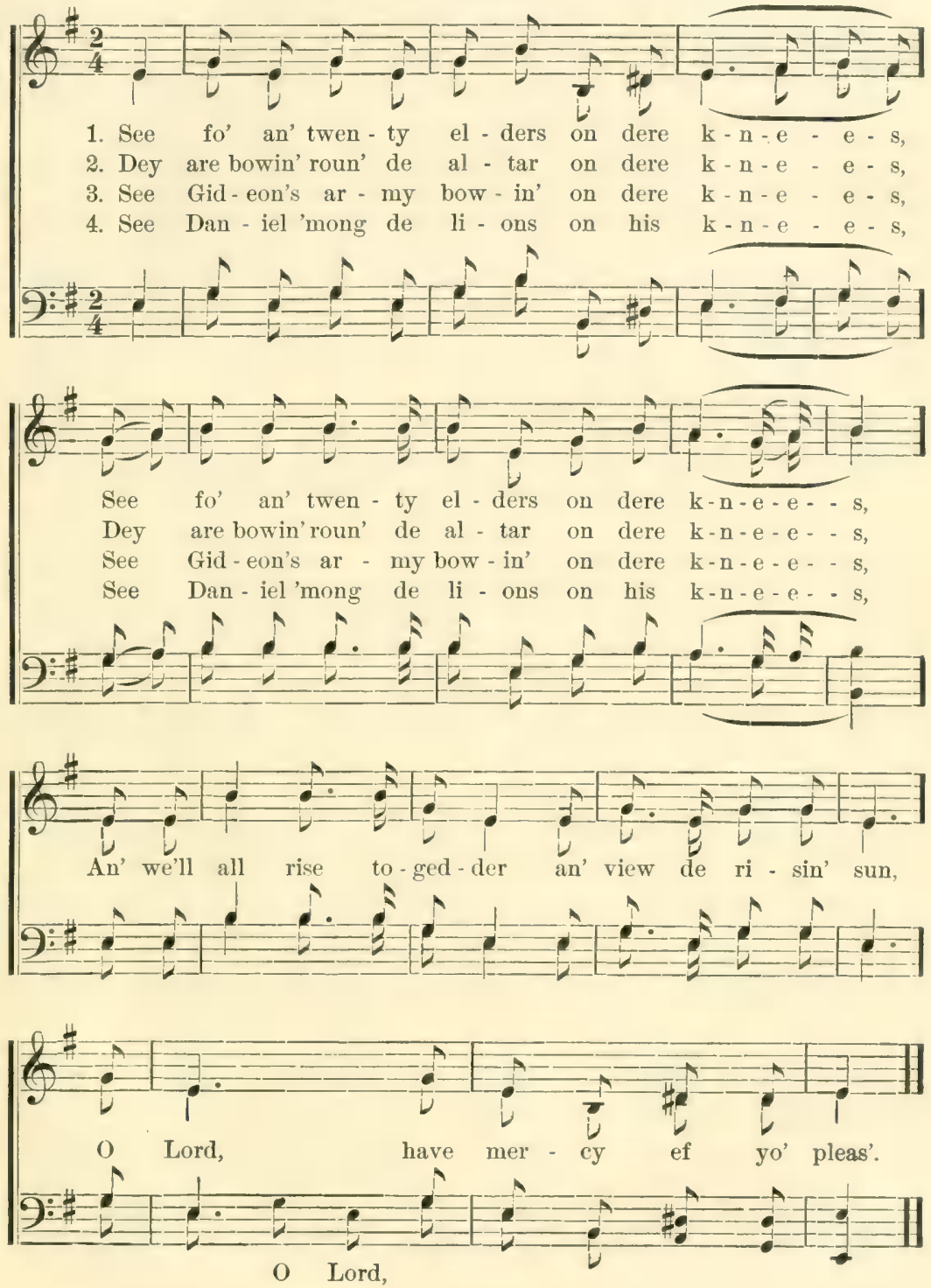


\section{Lioll de Ole chariot Along.}

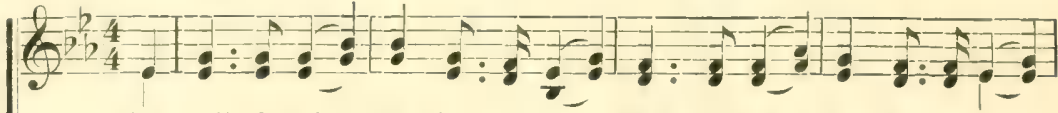
Oh, roll de ole char-iot a-long, Roll de ole char-iot a-long,

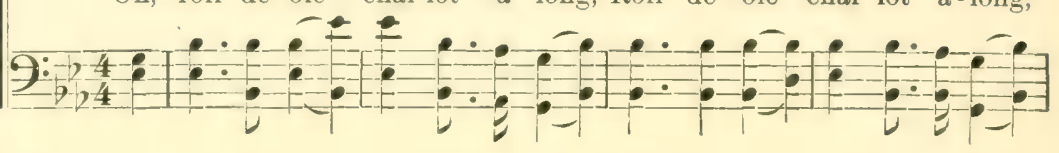
Fine.

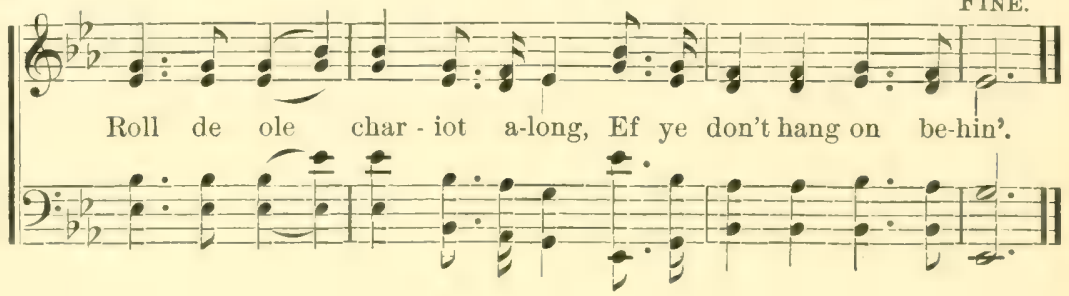
1. We are trav-el- lin'from mansions, to man-sions, to mansions. we are trav-el - lin' from mansions to man-sions to mansions, are trav-el- lin' from man-sions, 


\section{Lioll ae Ole Chariot Along.-Concluded.}

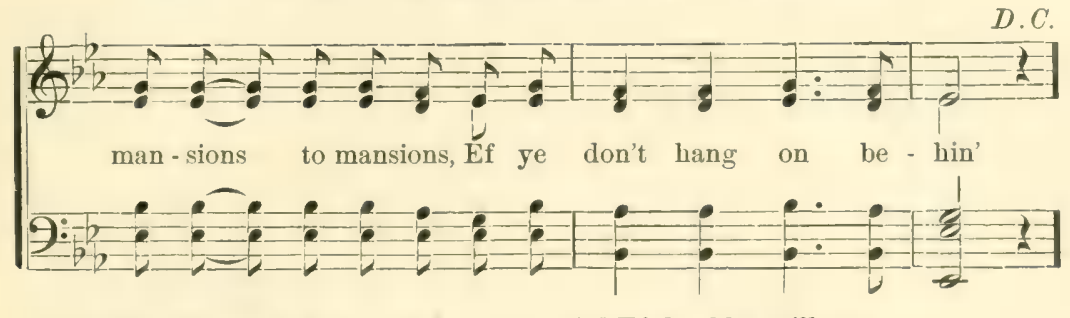

$2 \|$ :Gwine t'jine wid de hundred

An' forty-fo' thousand,

Ef ye don't hang on behin'.

$3 \|$ : Ef my farder will go

He shall wear a starry crown, :

Ef ye don't hang on behin'.

$4 \|$ :Ef my mudder will go

She shall wear a starry crown, :\|

Ef ye don't hang on behin'.
5 \|: Ef de elder will go

He shall wear a starry crown, :\|

Ef ye don't hang on behin'.

$6 \|:$ Ef de preacher's in de way,

Jus' roll it over, :\|

Ef ye don't hang on behin',

7 : Ef de deacon will go

He shall wear a starry crown, :\|

Ef ye don't hang on behin'.

\section{retonor Jahere is Good Ble Danicl?}

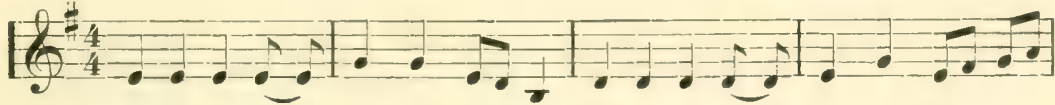

1. Wonderwhere is good ole Dan-iel, Wonderwhere is good ole Dan-iel,

2. He was cas' inde den ob li - ons, He wascas'inde den ob li - ons,

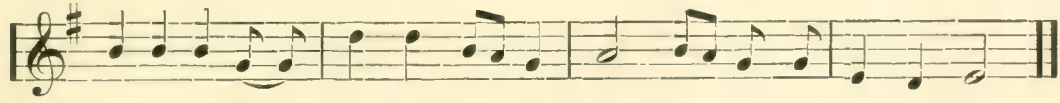

Wonder where is good ole Dan-iel, Way over in de Prom-ise' Lan'. Hewascas' in de den ob li - ons, Way over in de Prom-ise' Lan'.

$3 \|$ :By an' by we'll go an' meet him, :\|

Way over in de Promise' Lan'.
$6 \|:$ By an by we'll go an' meet dem, :\|

Way over in de Promise' Lan'.

$4 \|$ :Wonder where's dem Hebrew children:\| 7 $7:$ Wonder where is doubtin' Thomas, :\|

Way over in de Promise' Lan'.

Way over in de Promise' Lan'.

$5 \|$ : Dey come thro' de fiery furnace, :\| Way over in de Promise' Lan'.
$8 \|$ :Wonder where is sinkin' Peter, :\| Way over in de Promise' Lan'. 


\section{In the Haingorom.}
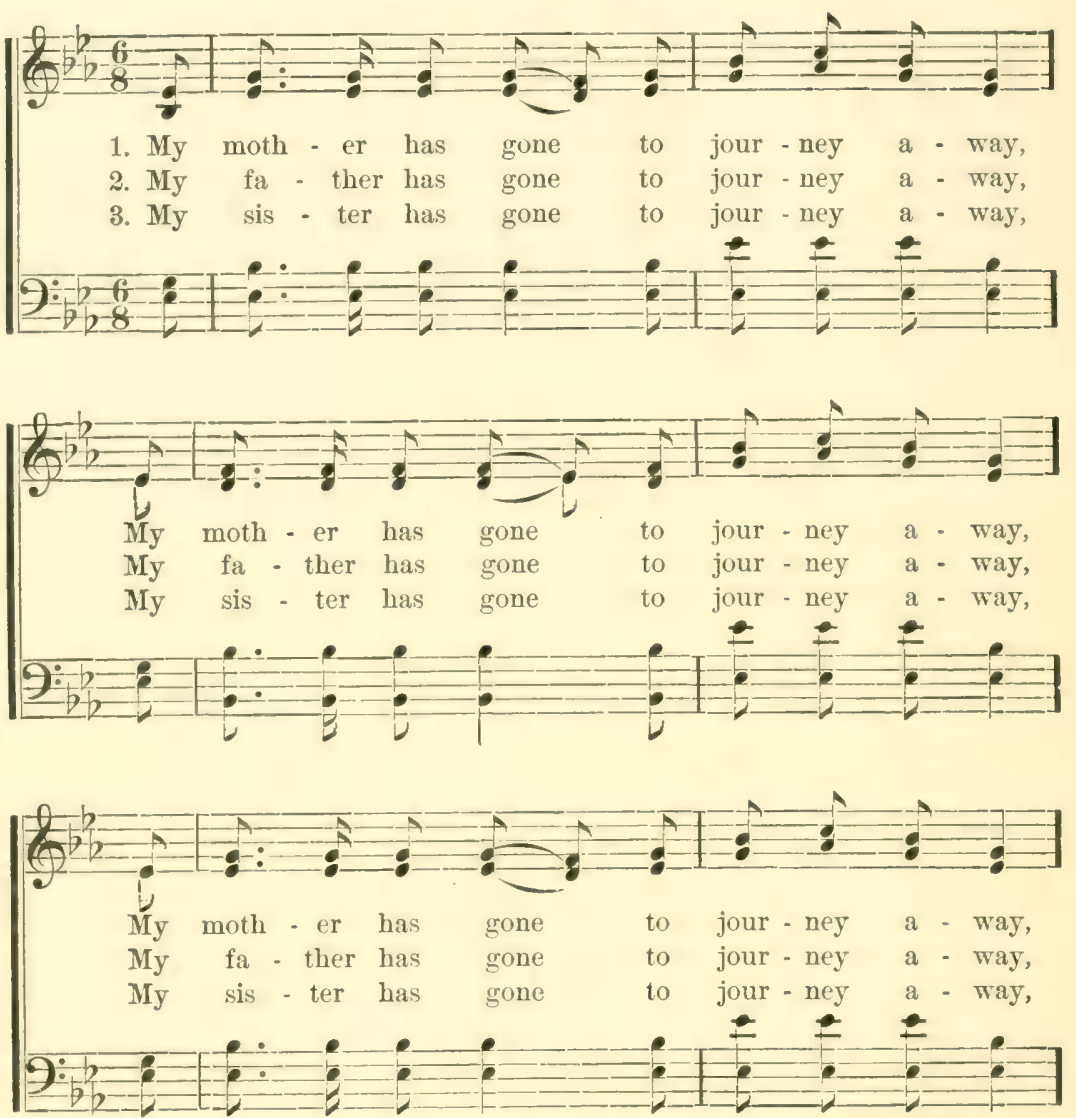

Fine.

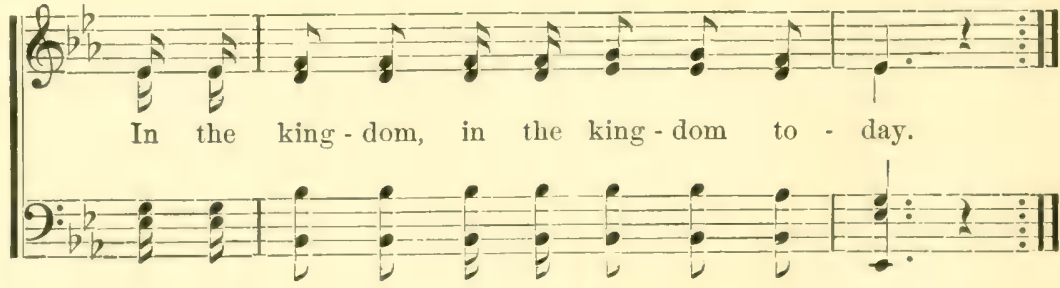




\section{En the Yaingorom.-Concluded.}

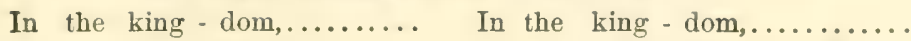

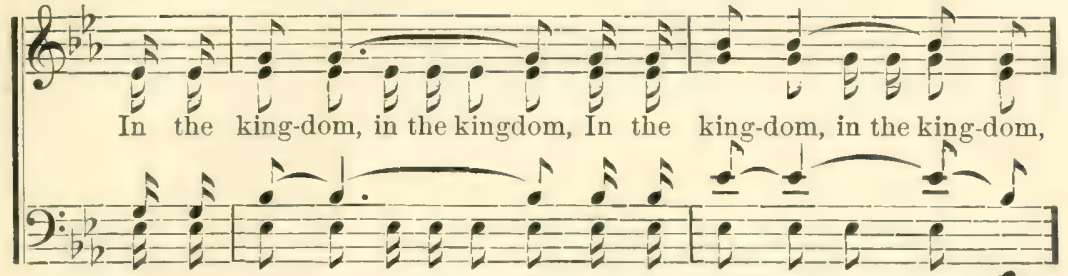

In the king-dom, in the kingdom, In the king-dom, sweet king-dom,

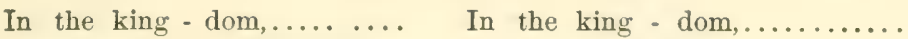

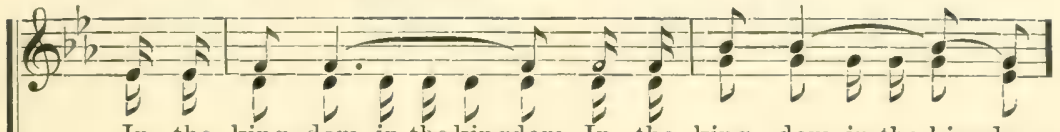

In the king-dom, in the kingdom, In the king - dom, in the kingdom,

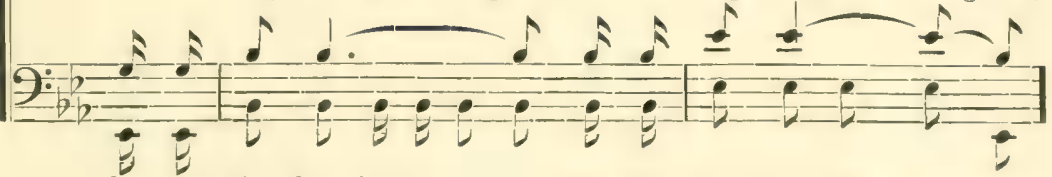

In the king-dom, in the kingdom, In the God-bless-ed king-dom,

In the $\operatorname{king}-\operatorname{dom} . . . \ldots \ldots$ In the $\operatorname{king} \cdot \operatorname{dom}, \ldots \ldots \ldots$

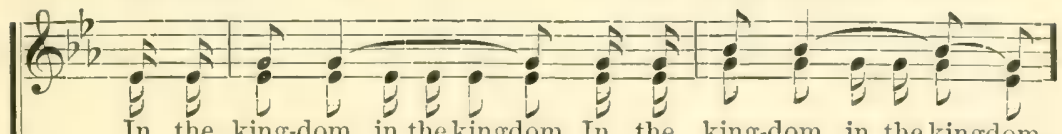

In the king-dom, in the kingdom, In the king-dom, in the kingdom,

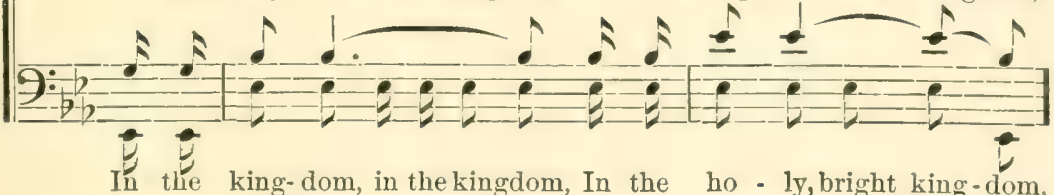

D. $C$.

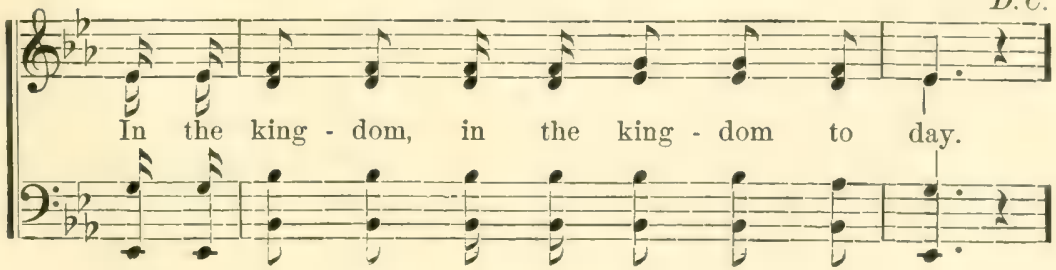




\section{A reatyed in a relber.}
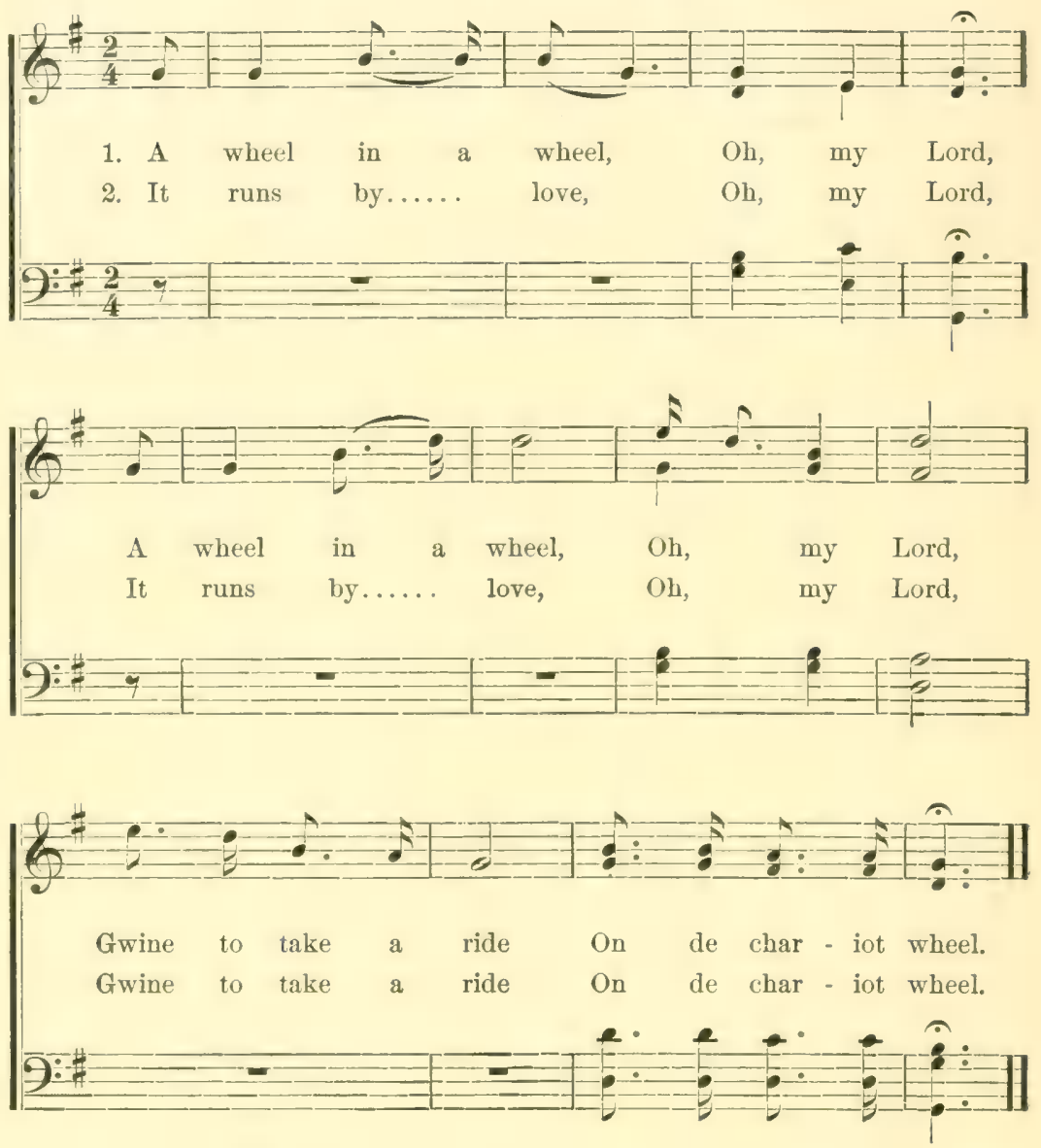

3 It runs by faith, Oh, my Lord, It runs by faith, Oh, my Lord,

Gwine to take a ride, On de chariot wheel.
4 Chariot's a comin', $\mathrm{Oh}$, my Lord, Chariot's a comin', Oh, my Lord, Gwine to take a ride, On de chariot wheel. 


\section{Ob, Jlorusalem!}

Chores.
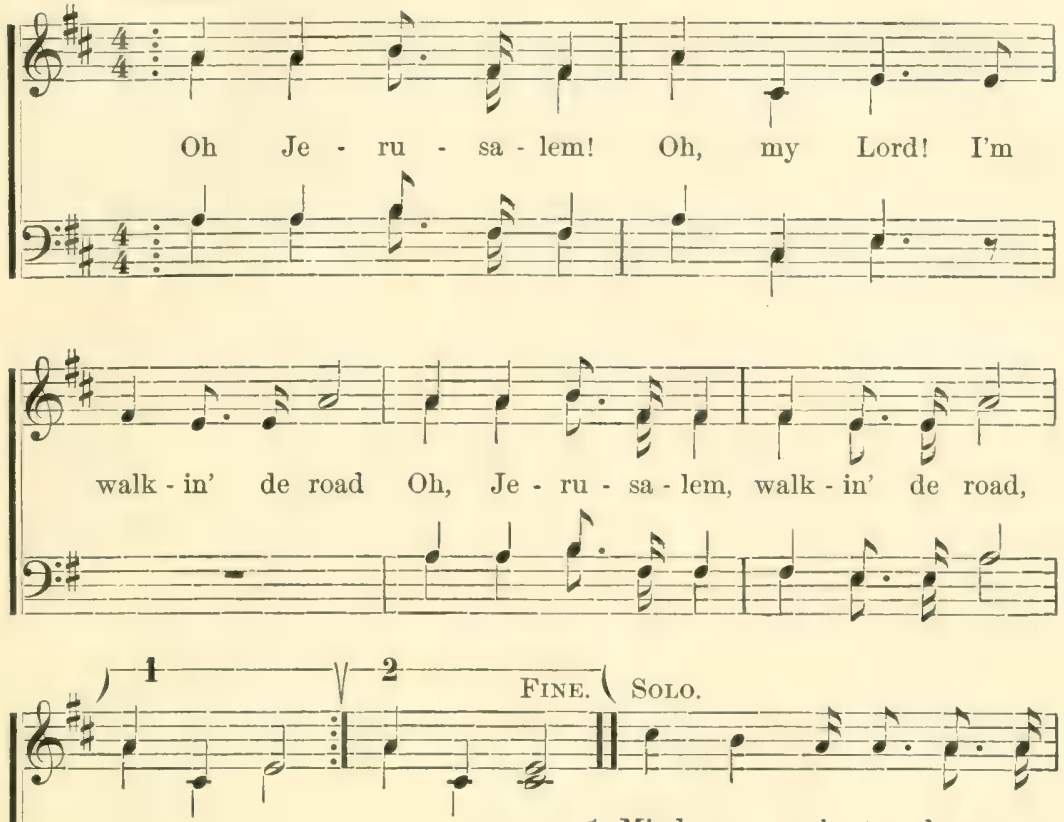

1. Mind my sis-ter how you

Oh my Lord! Oh my Lord! 2. My Lord God a'-might-y

3. Sea of glass all min-gled
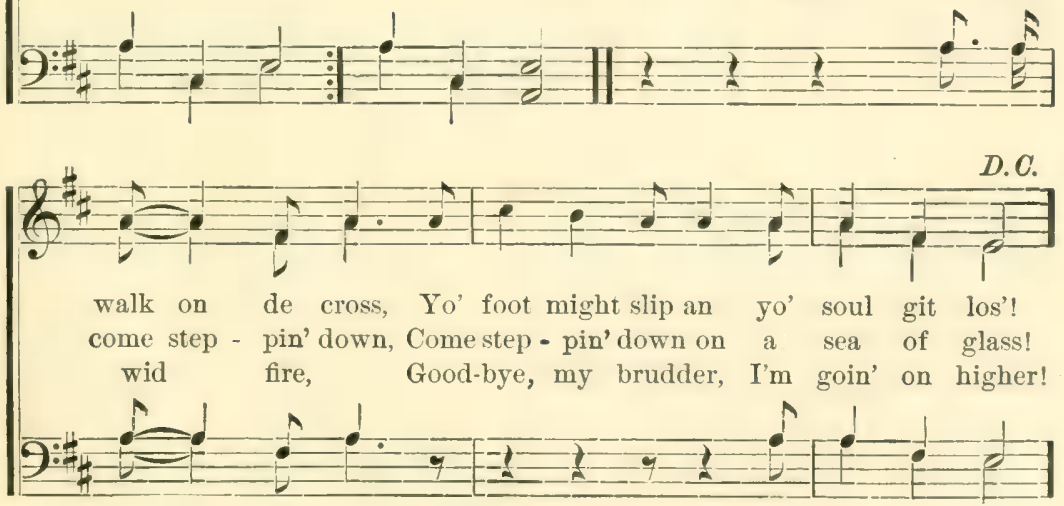


\section{Ob Hes, Yonder Comes fty Ilord.}
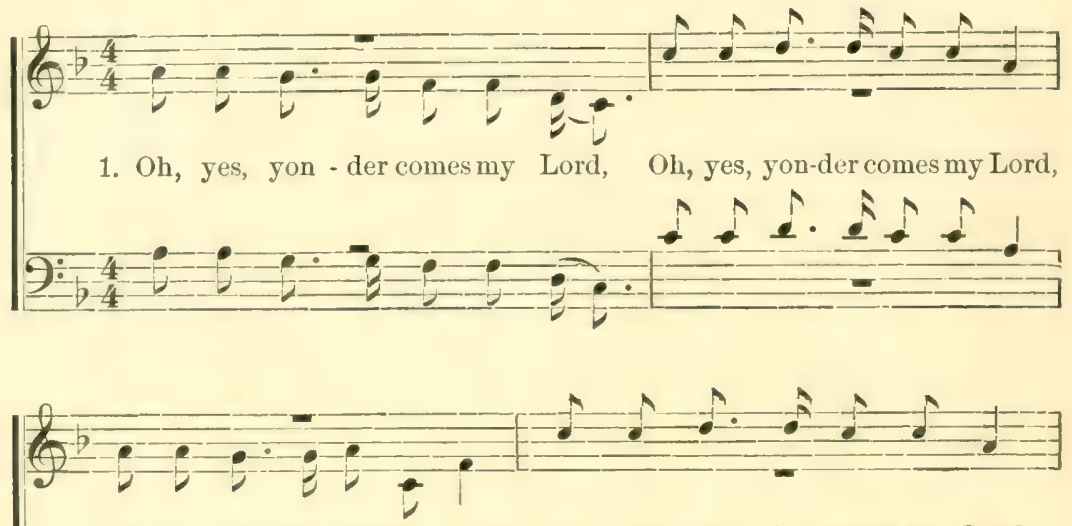

Oh, yes, yon-der comes my Lord, Oh, yes, you - der comes my Lord,
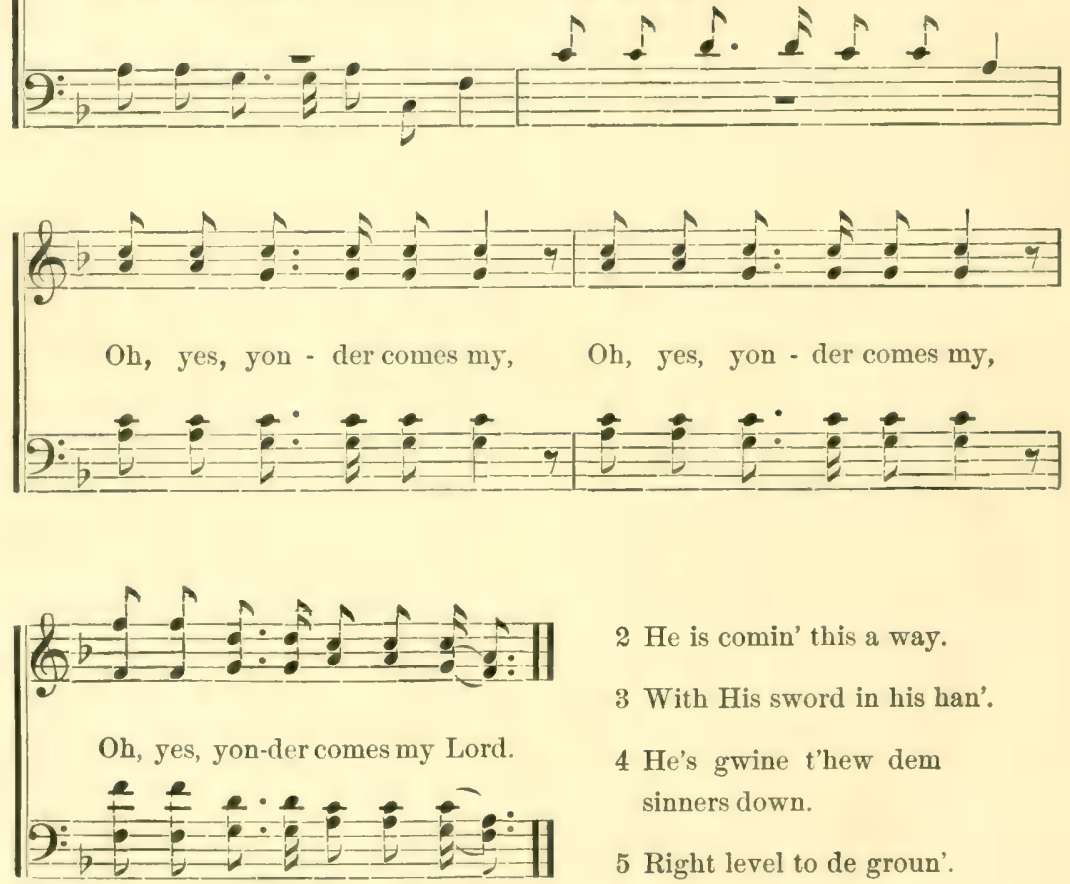

$2 \mathrm{He}$ is comin' this a way.

3 With His sword in his han'.

4 He's gwine t'hew dem sinners down.

5 Right level to de groun'. 


\section{Go ftary, an' Toll oe hell.}
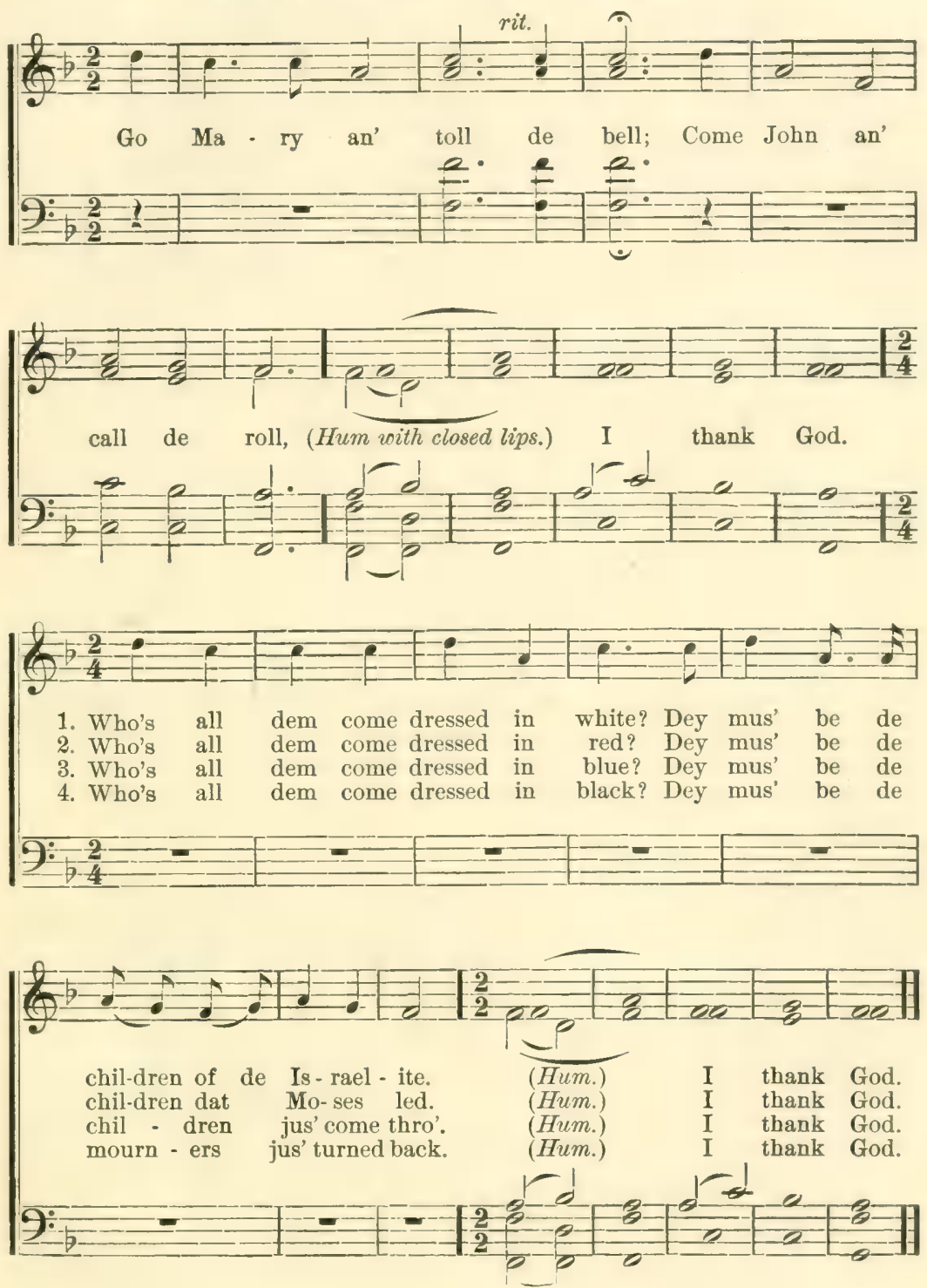


\section{Dh, ffrecon!}
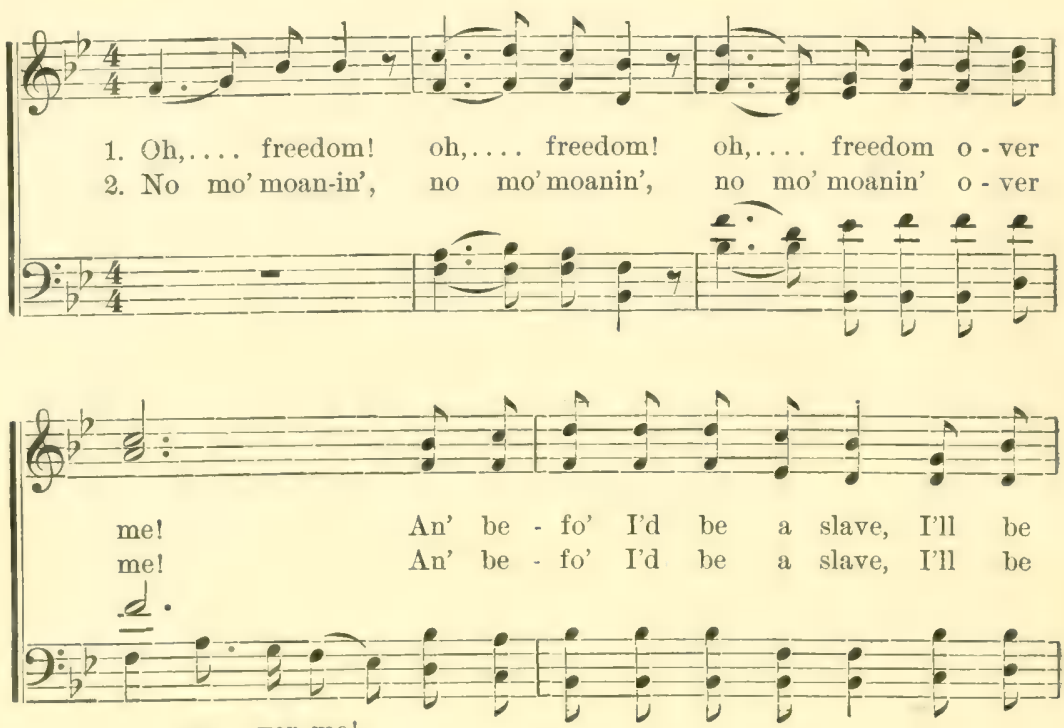

o - ver me!

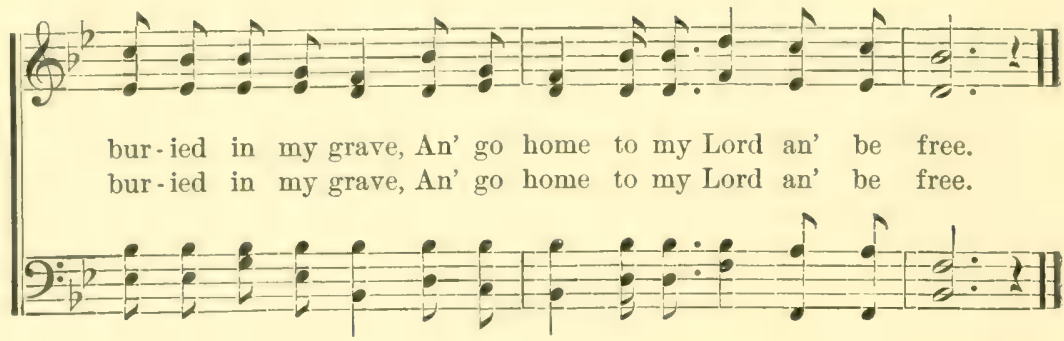

3 No mo' weepin' over me,

An' befo' I'd be a slave,

I'll be buried in my grave,

An' go home to my Lord an' be free.

4 There'll be singin' over me,

An' befo' I'd be a slave,

I'll be buried in my grave,

An' go home to my Lord an' be free.
5 There'll be shoutin' over me,

An' befo' I'd be a slave,

I'll be buried in my grave,

An' go home to my Lord an' be free.

6 'There'll be prayin' over me,

An' befo' I'd be a slave,

I'll be buried in my grave,

An' go home to my Lord an' be free. 


\section{Sometimes If fferl Ilíke a ftlotherless chyild.}

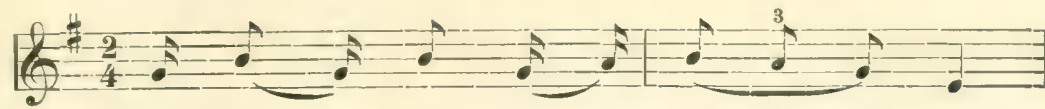

1. Some-times I feel like a moth - er - less child,

2. Ef this... was judg - ment...... day,

3. Some-times I feel like I'm al - mos' gone.

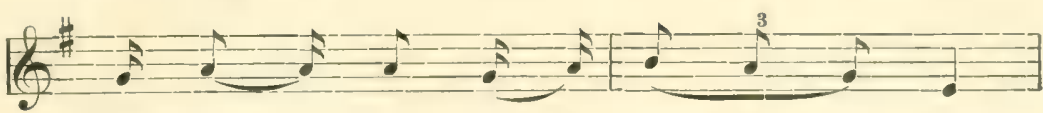

Some-times I feel like a moth - er - less child, Ef this... was judg - ment........ day, Some-times I feel like I'm al - mos' gone,

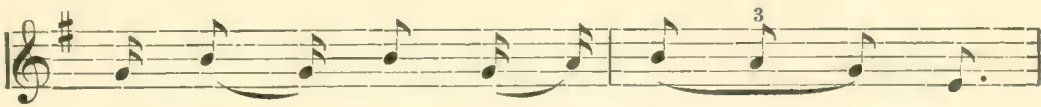

Some-times I feel like a moth -- er - less child,

Ef this.... was judg - ment.......... day,

Some-times ' I feel like I'm al - mos' gone,
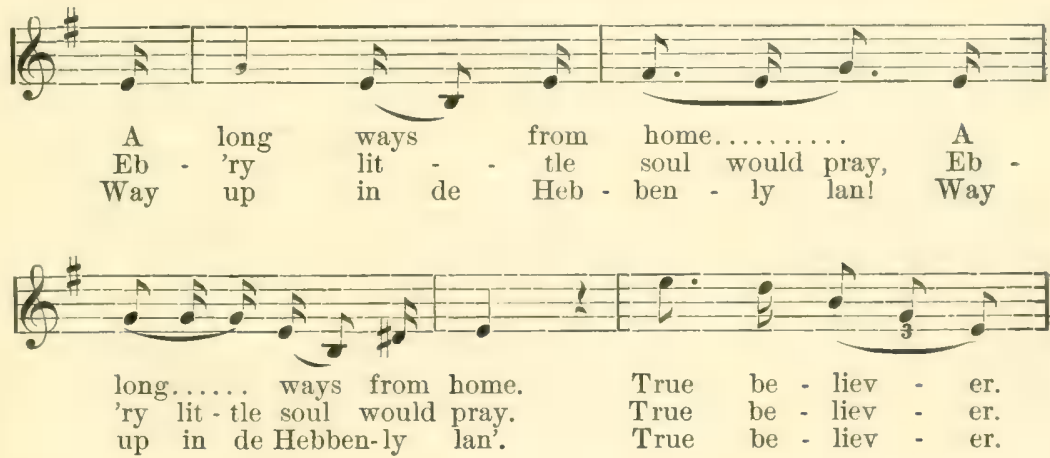

REFRAIN. $p p$

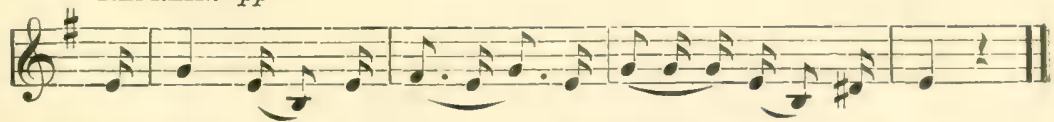

A long ways from home,.... A long ways from home.

Eb - 'ry lit - tle soul would pray, Eb-'ry lit- tle soul would pray.

Way up in de Heb-benly lan', Way up in de Hebben-ly lan'. 


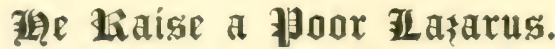

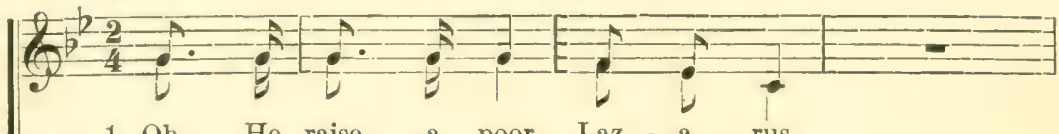

1. Oh, He raise a poor Laz - a - rus,

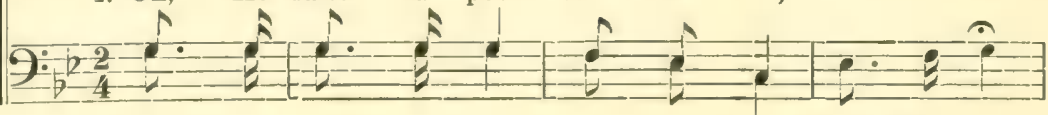

Raise him up,
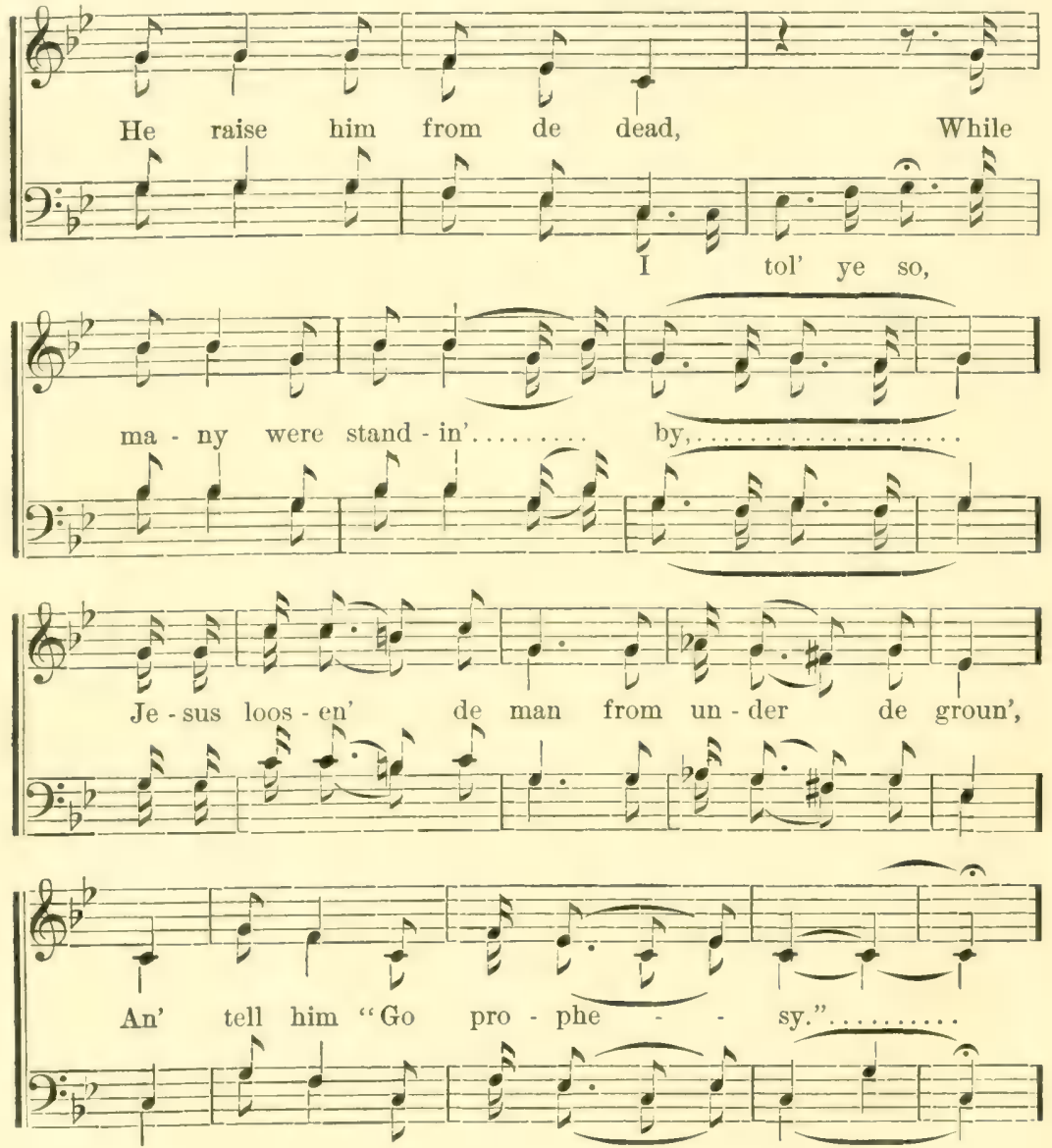


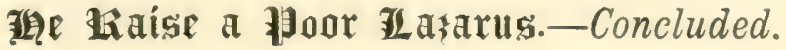

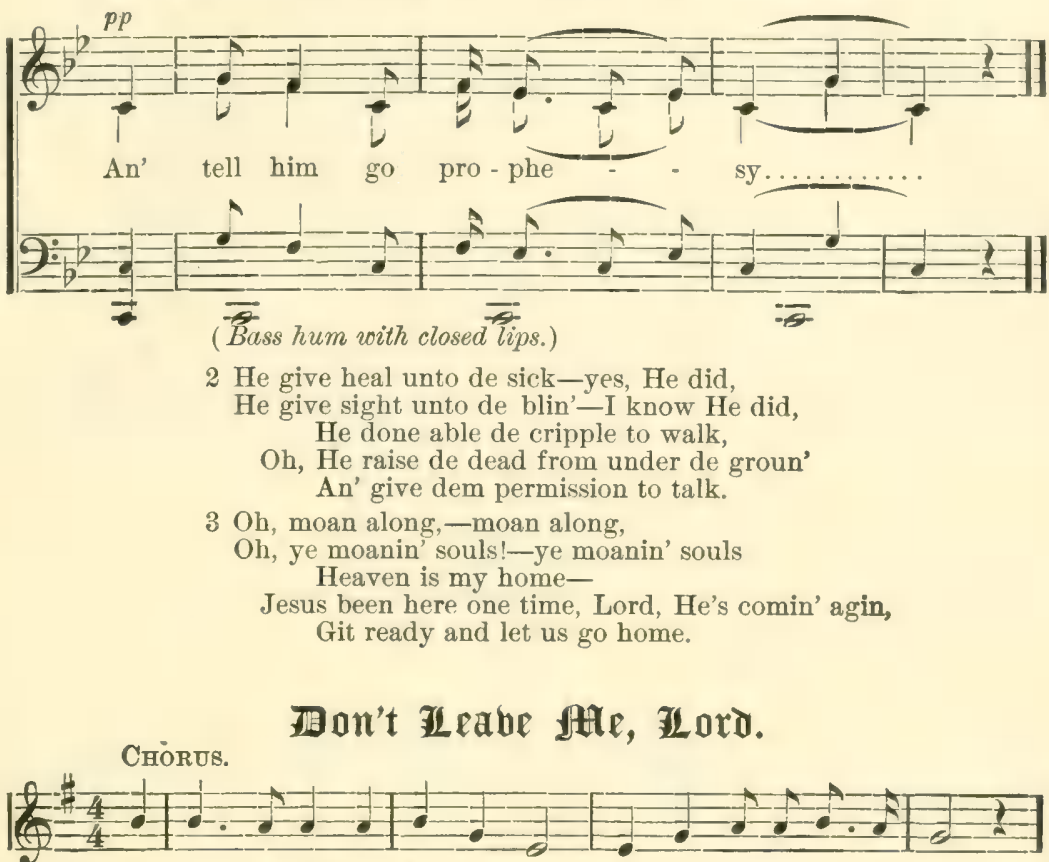

Don't leave me,Lord, Don't leave me,Lord. Lord, don't leave a me be - hin',

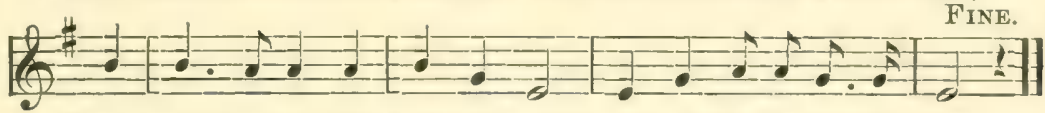

Don't leave me,Lord, Don't leave me, Lord. Lord, don't leave a me be- hin' .

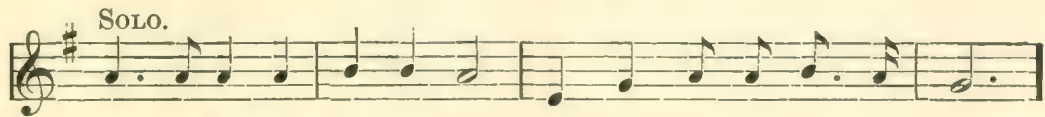

1. Je-sus, Je-sus is my Frien', Lord, don'tleave a me be - hin',

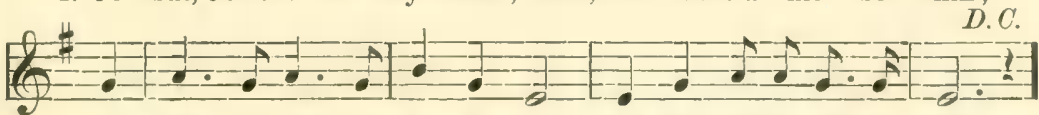

He will go with me to de en' Lord, don't leave a me be - hin'.

2 No use talkin' what you gwine t' do,

Don't 'tend t' 'ny my God for you. - Cho.

3 I don't wan' t' stumble an' I don't wan' t' stop,

I don't wan' t' be no stumblin' block. - Cho. 


\section{IJacob's Illador.}
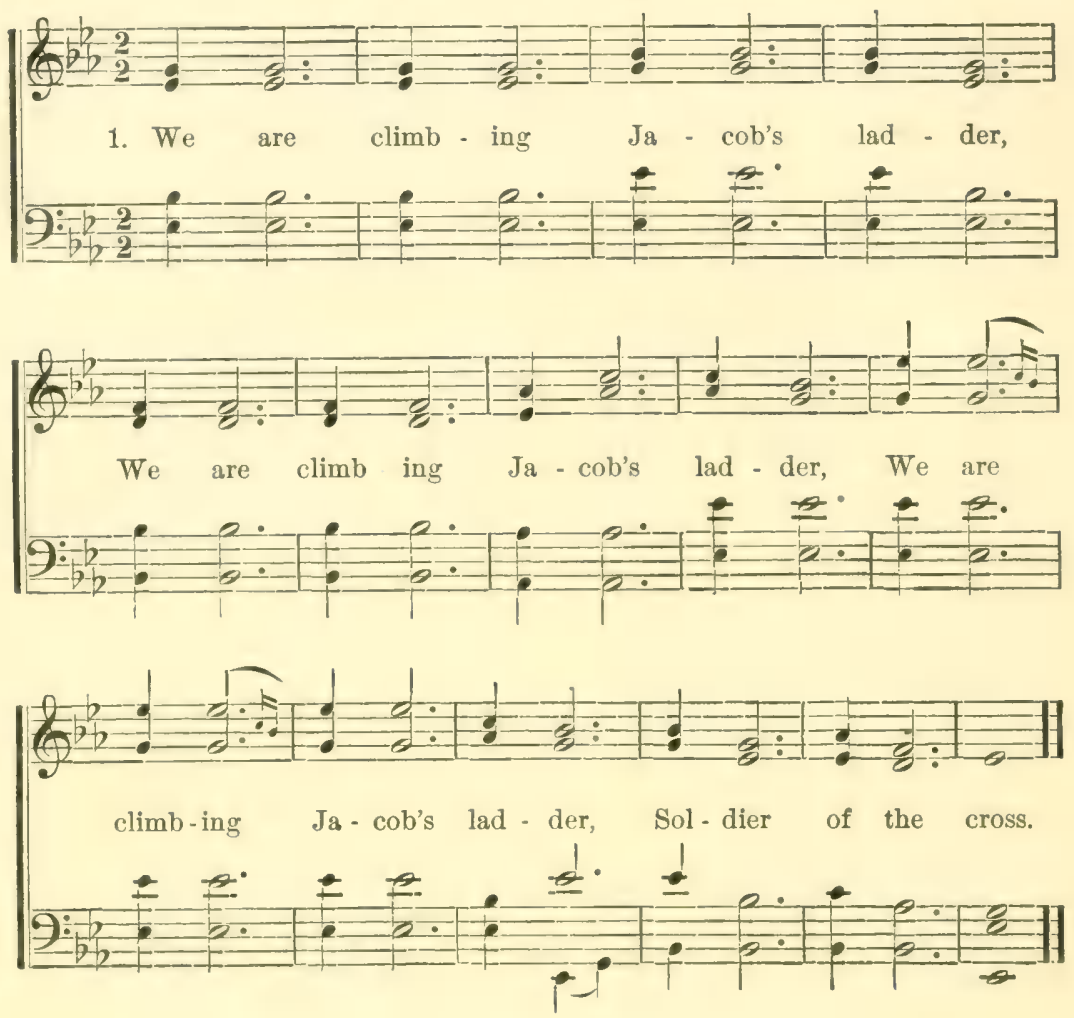

2 Every round goes higher and higher, Soldier of the cross.

3 Sinner, do you love my Jesus ?

Soldier of the cross.

4 If you love Him, why not serve Him ?

Soldier of the cross.

5 Do you think I'd make a soldier? Soldier of the cross.

6 We are climbing higher and higher, Soldier of the cross. 


\section{The Dommard Lioar Es cromaror.}

\section{Chorus.}
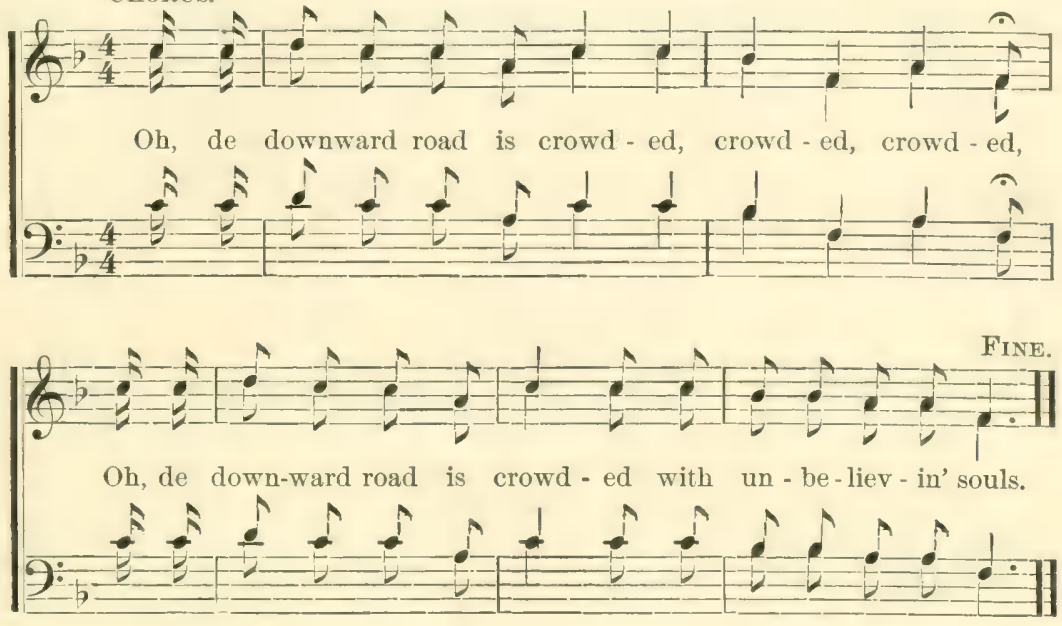

SoLo.

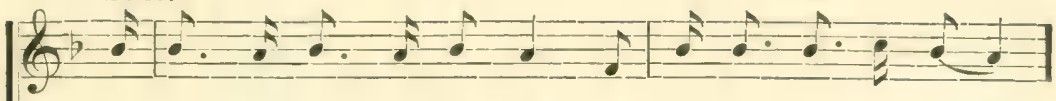

1. Come, all ye way-ward trav' lers, An' let us jine an' sing,

$9 \div \frac{1}{b}=$

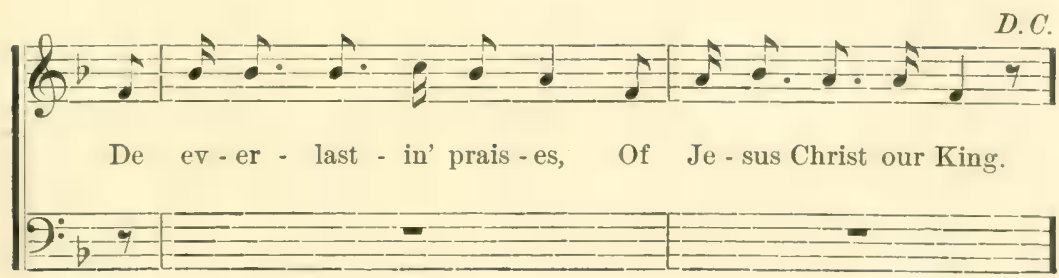

2 Ole Satan's mighty busy,

He follers me night an day,

An every where I 'pinted,

Dere's somethin' in my way.
3 When I was a sinner,

I loved my distance well,

But when I come to fin' myself,

I was hangin' over Hell. 


\section{Live On.}

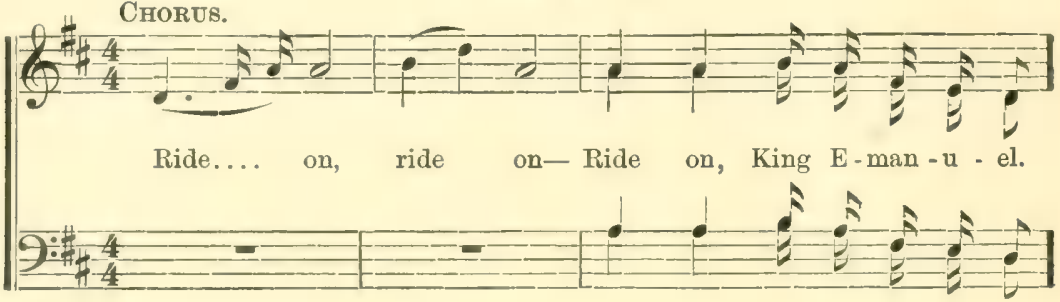

FINE.

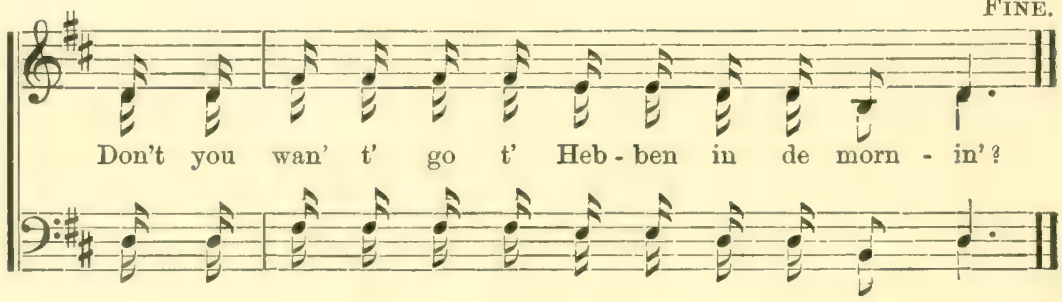

Solo.
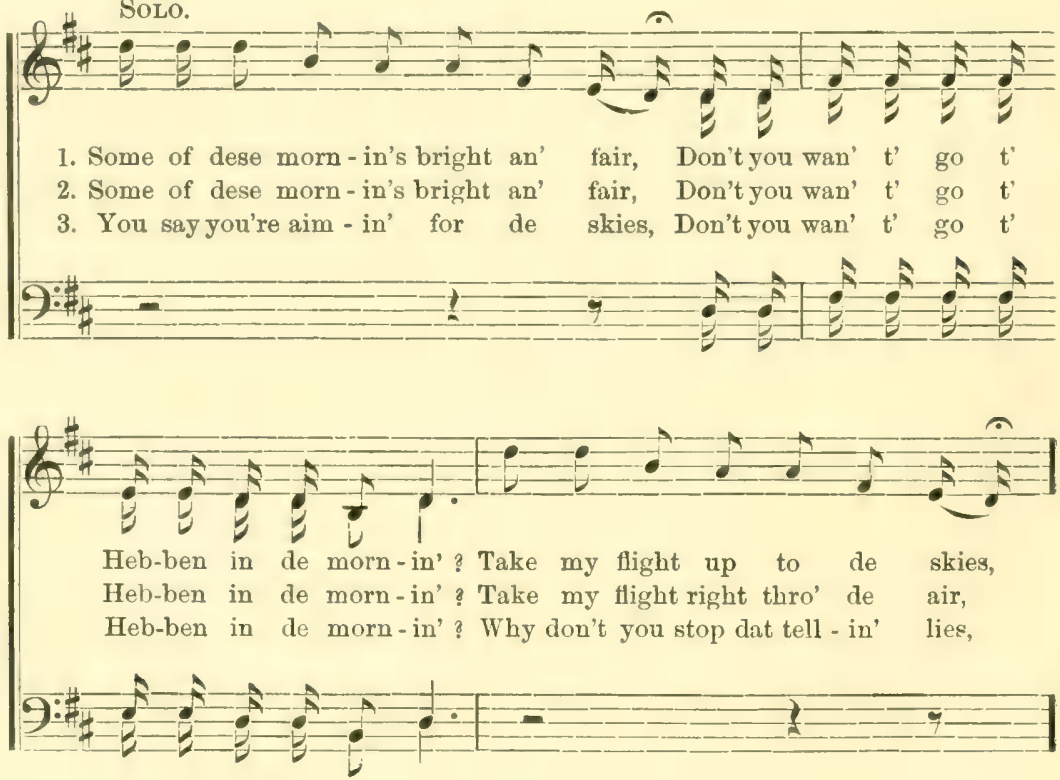
Zíne On.-Concluded.

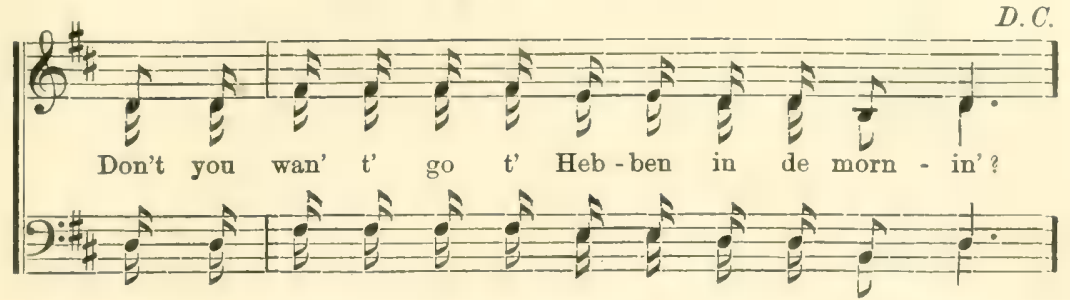

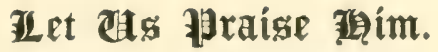
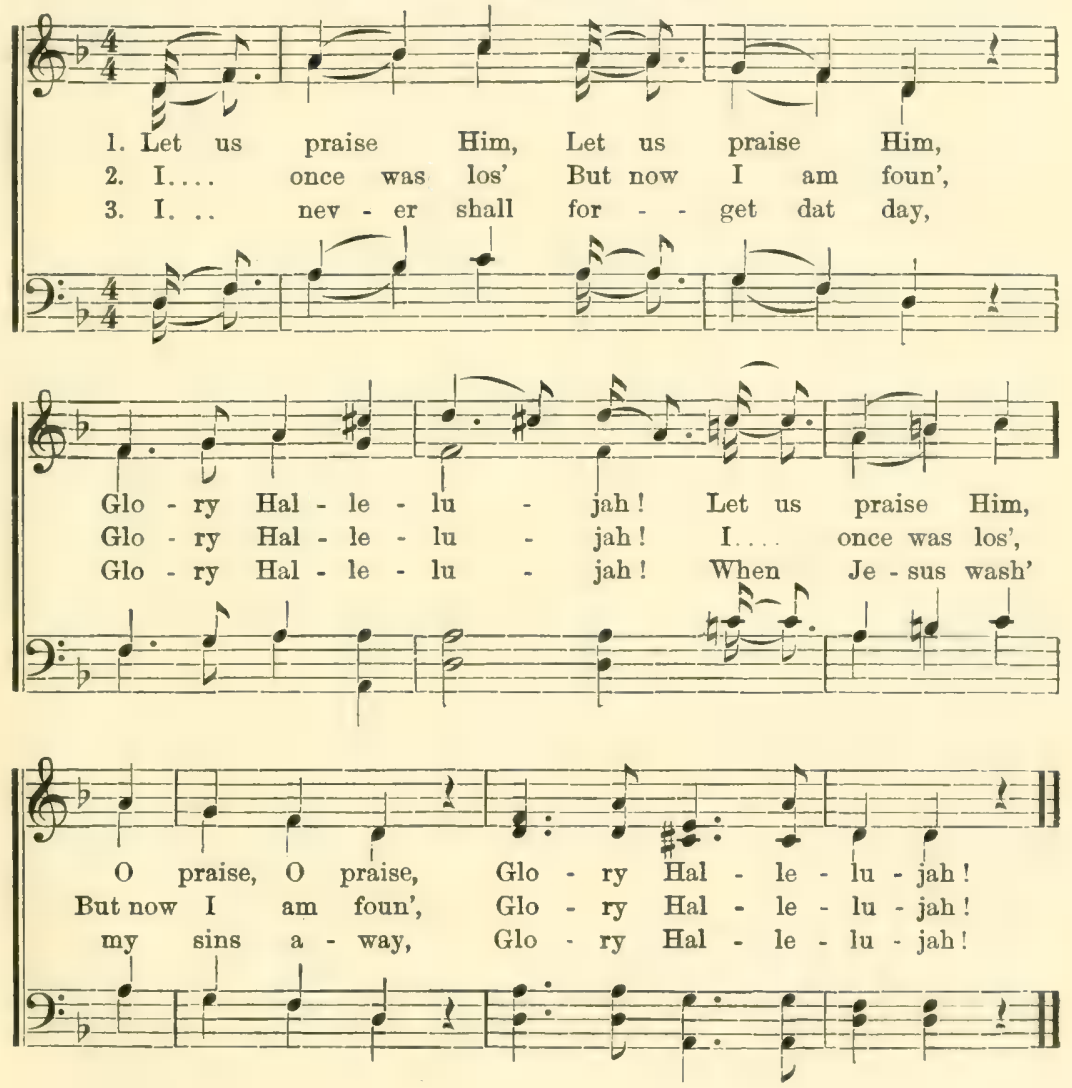

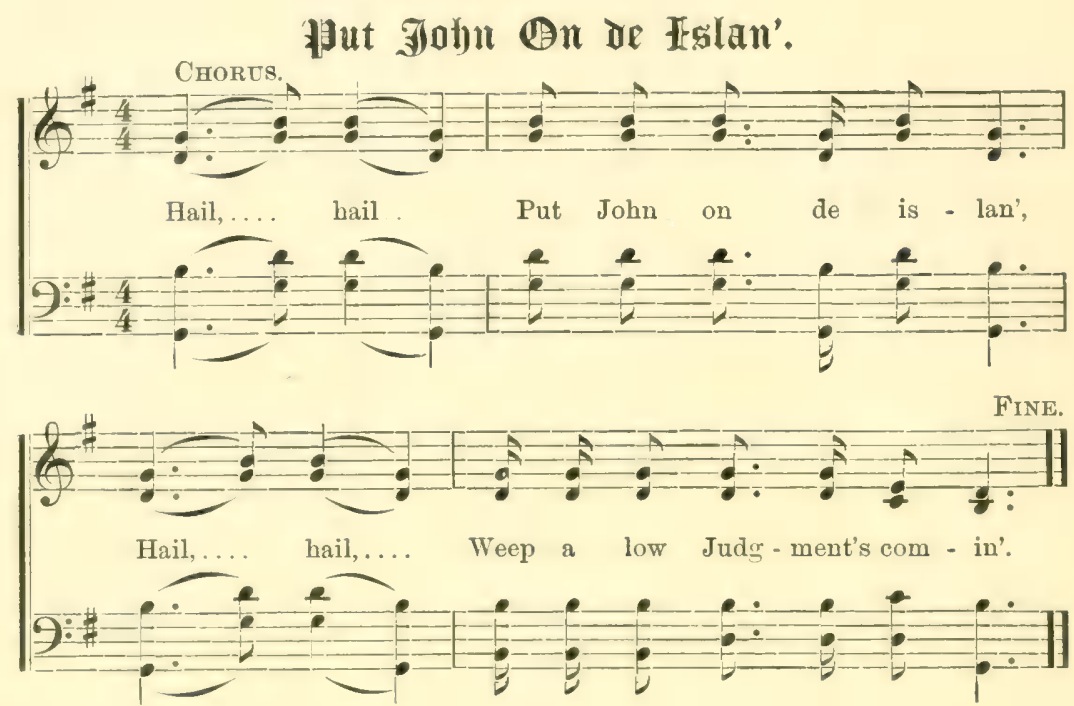

Solo.

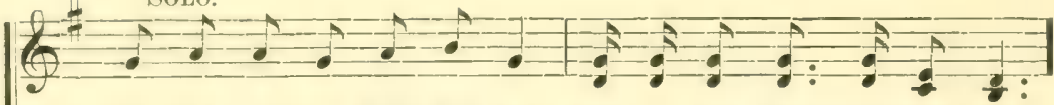

1. You got Je - sus, hold Him fas' Weep a low, Judg-ment's com - in',

2. Did'nt kuow Christ was into de fiel', Weep a low, Judg-ment's com - in',

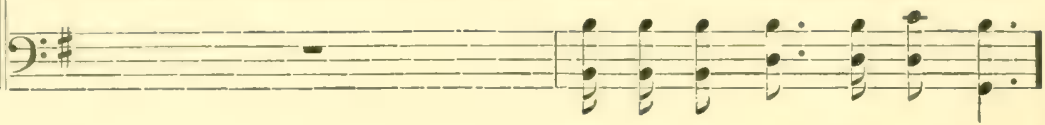

D.C.

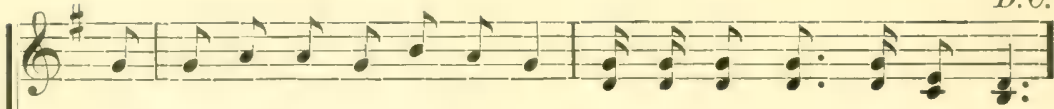

De grace of God you shall re-ceive, Weep a low, Judg-ment's com - in'. Till I heard de rumblin' of de chariot wheel, Weep a low, Judg-ment's com - in'.

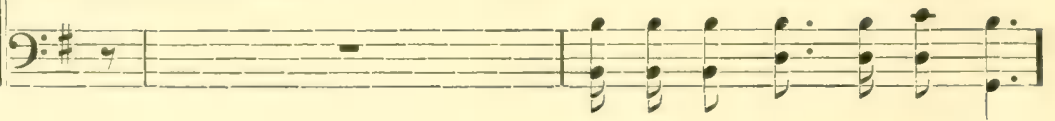

3 Gwine dowu Jordan t' pay my fare, Weep a low, Judgment's comin', Have a little meetin' when I gits dere, Weep a low, Judgment's comin'
4 Gwine up t' Hebben, don't wan' t' stop, Weep a low, Judgment's comin', Don't wan' t' be no stumblin' block, Weep a low, Judgment's comin'. 


\section{rete Are Luilding an a Liock.}
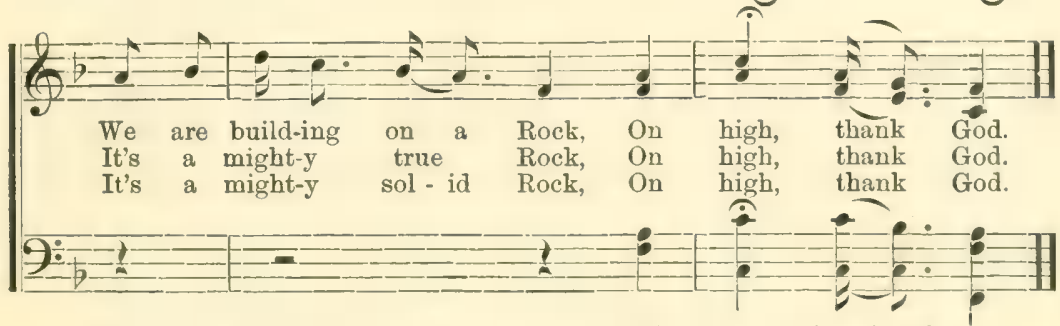

4 Christ Jesus is the Rock, On high, on high.

Christ Jesus is the Rock, On high, thank God.

5 The very gates of Hell, On ligh, on high,

The very gates of Hell, On high, thank God.
6 Will not prevail against it, On high, on high,

Will not prevail against it, On high, thank God.

7 Help me to build on the Rock, On high, on high,

Help me to build on the Rock. On high, thank God.

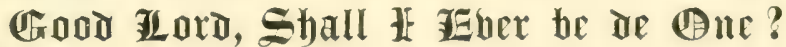
CHORUs.

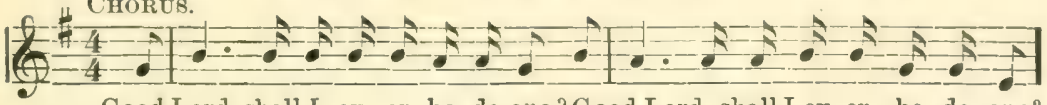

Good Lord, shall I ev-er be de one? Good Lord, shall I ev-er be de one?

Fine.

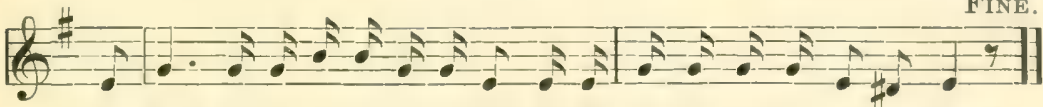

Good Lord, shall I ev - er be de one, To get ov - er in de Promise' Lan'? Solo.

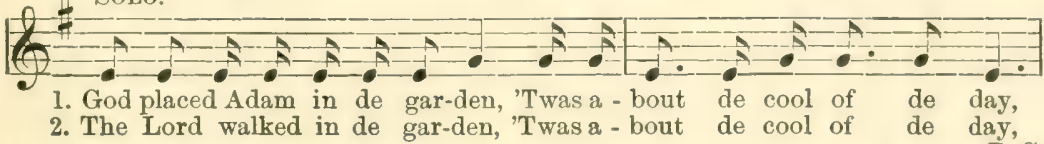

2. The Lord walked in de gar-den, "Twasa-bout de cool of de day,

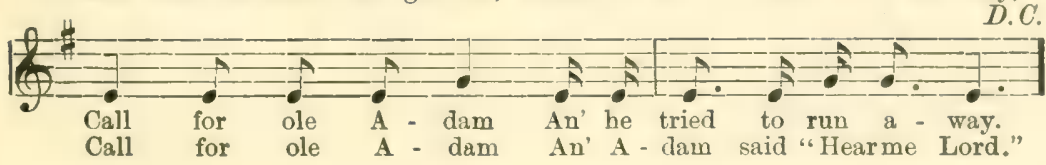




\section{In Bright ftansions Abobe.}

Chorus.

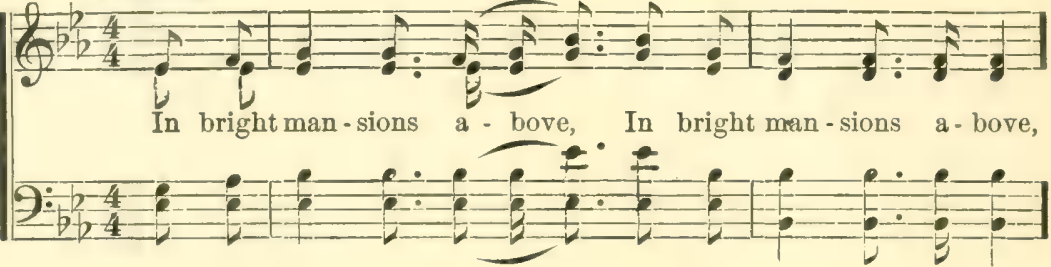

Fine.

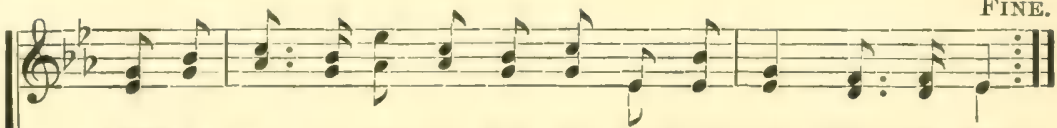

Lord, I wan' t' live up yon-der, In bright man - sions a-bove.

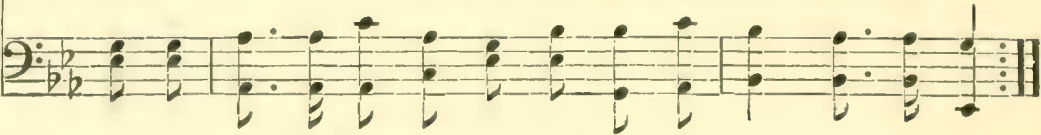

Soro.

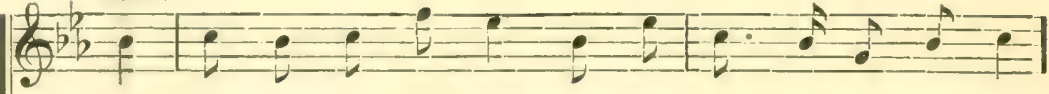

1. My moth-er's gone to glo - ry, I wan' t' go there too,

2. My fa-ther's gone to glo - ry, I wan' t' go there too,

3. My sis-ter's gone to glo - ry, I wan' t' go there too,

$9 \div \frac{p^{2-1}}{p_{2}}=$

D.C.

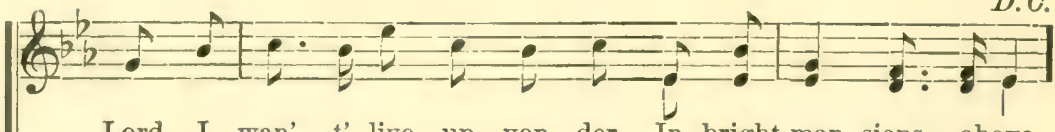

Lord, I wan' t' live up yon-der, In bright man-sions above.

Lord, I wan' t' live up yon-der, In bright man-sions above.

Lord, I wan' t' live up yon-der, In bright man-sions above.

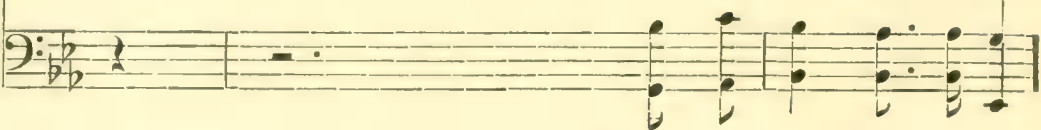

4 My brother's gone to glory,

I wan' t' go there too, Lord,

I wan' $t$ ' live up yonder,

In bright mansions above.
5 My Saviour's gone to glory, I wan' t' go there too, Lord, I wan' $t$ ' live up yonder,

In bright mansions above. 


\section{Swing 320 w, ethariot.}

Solo.

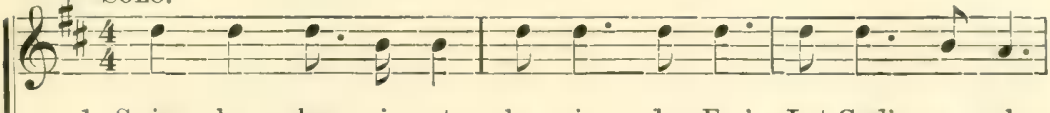

1. Swing low, char - i - ot, low in de Eas', Let God's peo-ple

2. Swing low, char - i - ot, low in de Wes', Let God's peo-ple

3. Swing low, char - i - ot, low in de North, Let God's peo-ple

4. Swing low, char - i - ot, low in de South, Let God's peo-ple

$9 \div \frac{4}{4-2}=-$
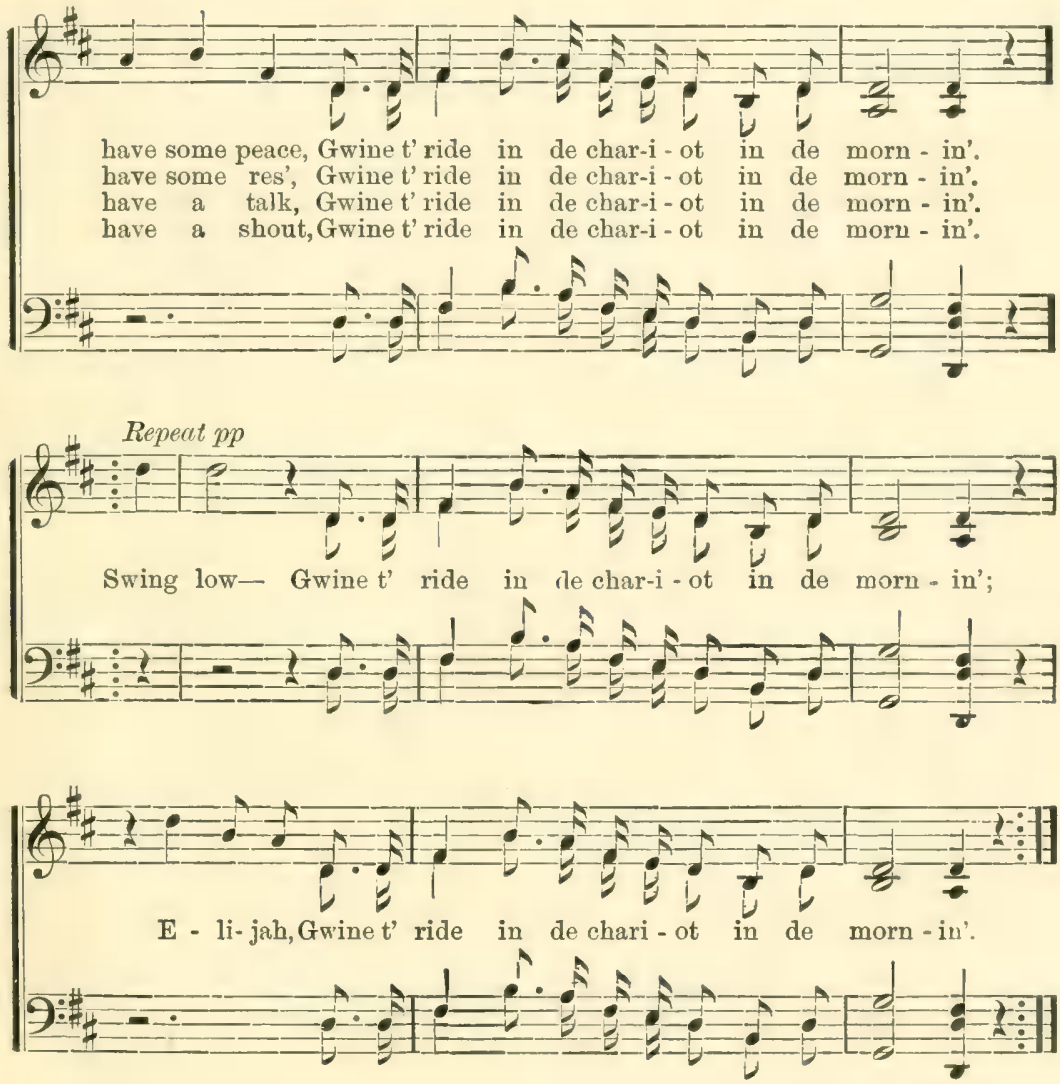


\section{尹Jilgrim's Song.}

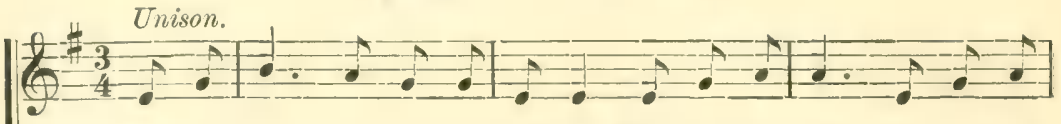

1. I'm a poor, way-far - in' stranger, While journeyin' thro this world of

2. I know dark clouds will gath-er round me, I know my way is rough an'

3. I'll soon be free from ev - 'ry trial, My body will sleep in the ole church-
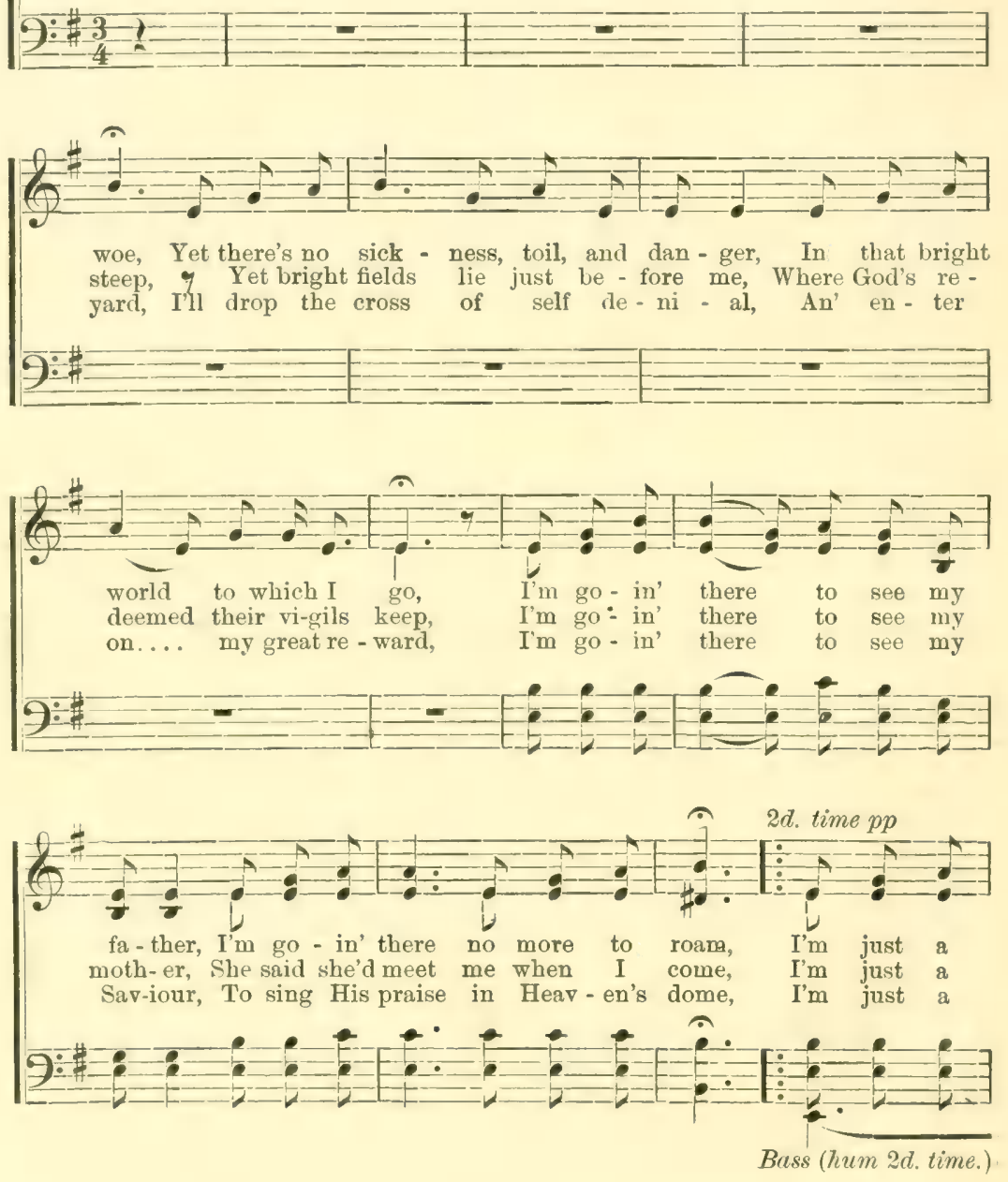


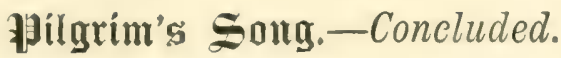

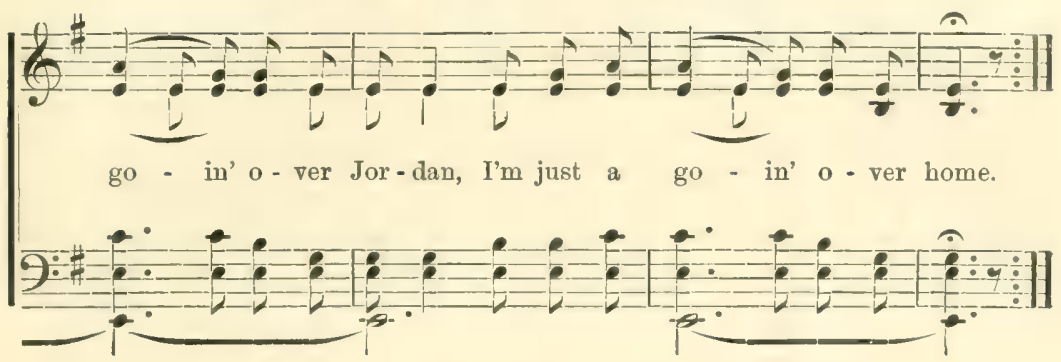

\section{刃on't be Jeteary, Trabeller.}

CHoRus Voices in Unison.

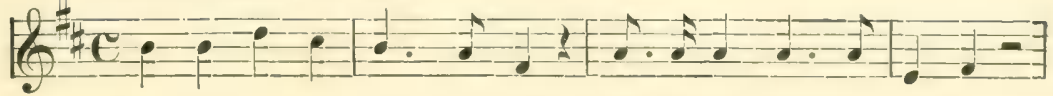

Don't be wea -ry, trav - el-ler, Come a-long home to Je-sus,

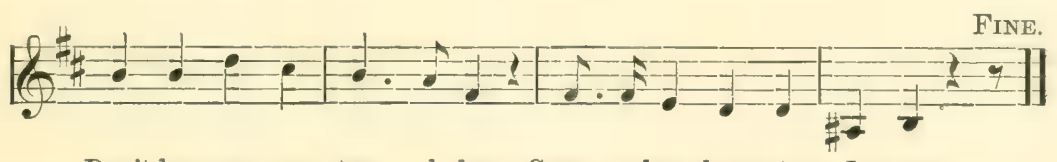

Don't be wea - ry trav - el-ler, Come a-long home to Je-sus.

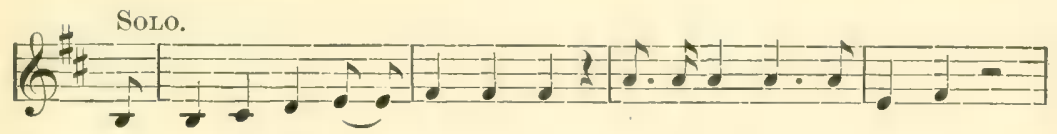

1. My head got wet with the midnight dew, Come along home to Je-sus,

2. Where to go I did not know, Come along home to Je-sus,

3. ' I look at de worl' an' de worl' look new, Come along home to Je - sus,

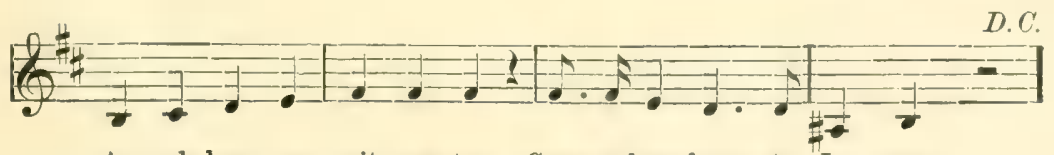

An-gels bear me wit-ness too, Come a-long home to Je - sus.

$\mathrm{Ev}$ - er since IIe freed my soul, Come a-longhome to Je - sus.

I look at my hands an' they look so too, Come a-long home to Je - sus. 


\section{If Am Goin' to Join in Tyis Armm.}

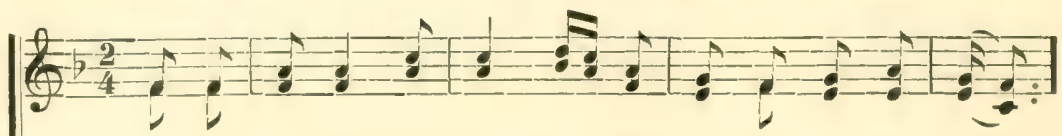

1. I am go - in' to join in this ar - my of my Lord,

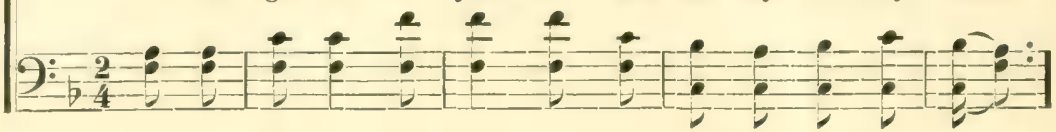

Fine.
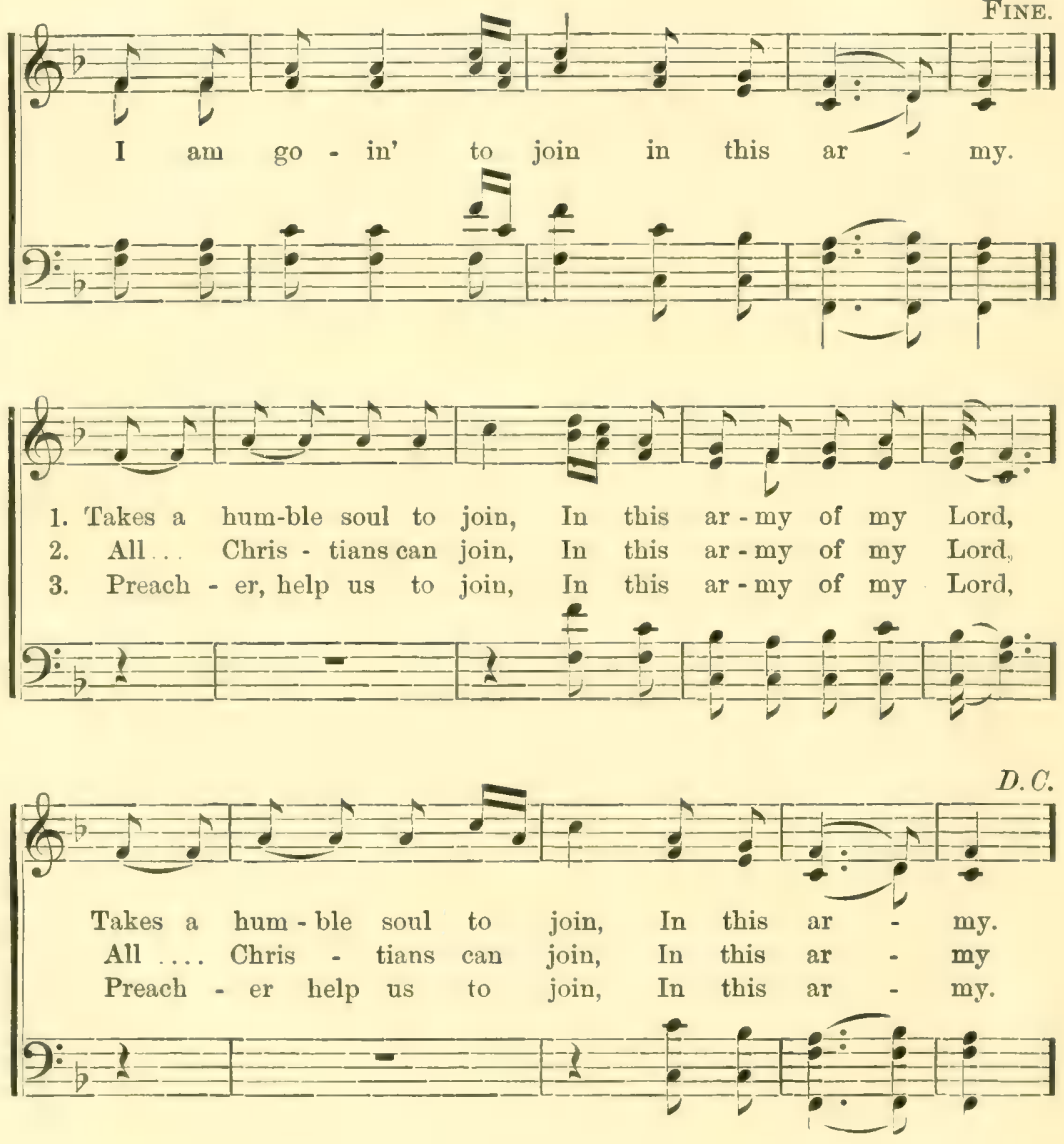
CABIN AND PLANTATION SONGS.

129

Tell Joists.

Chorus.
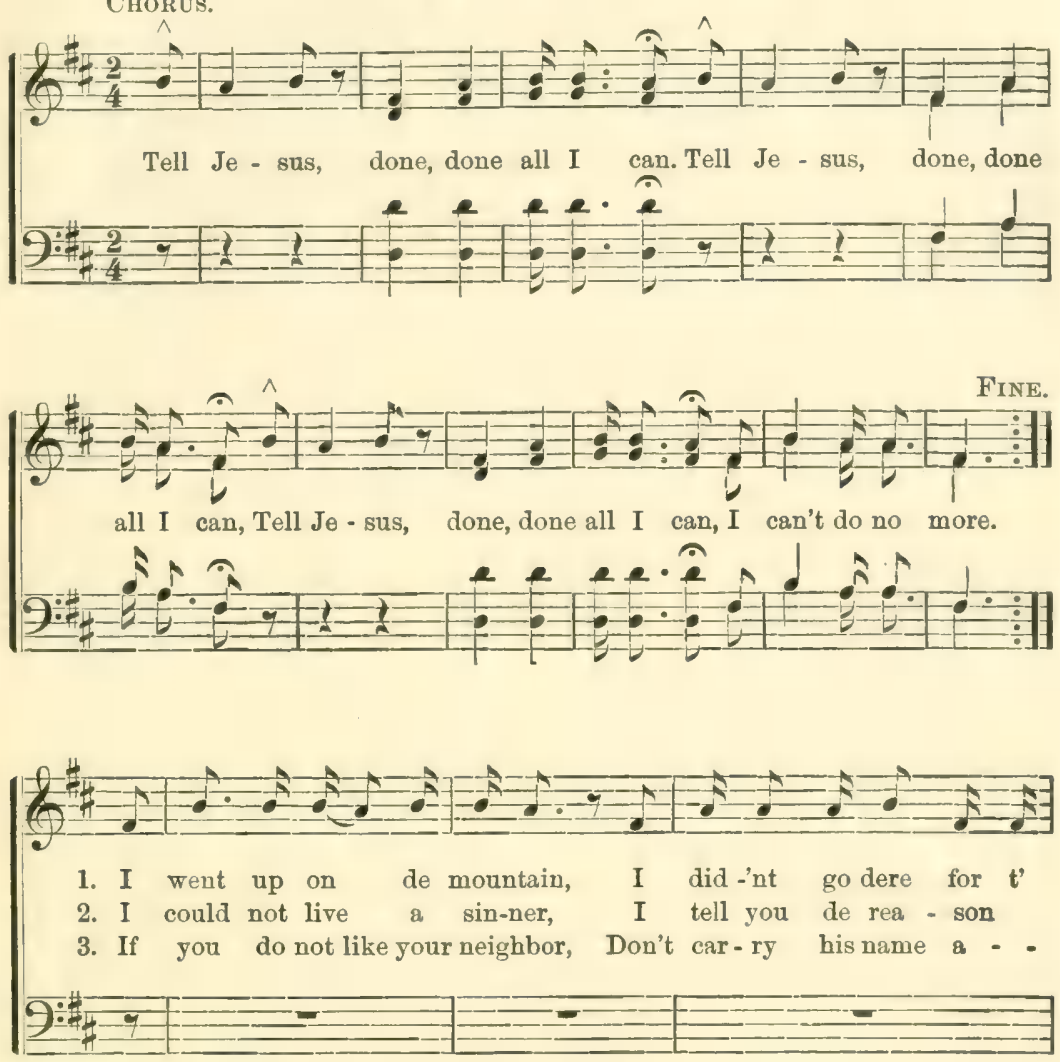

D.C.

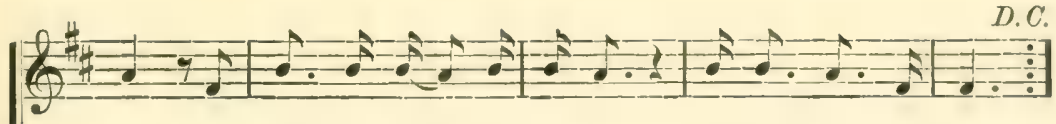

stay. But when my soul got happy, Den I stayed all day. why. Be 'frail my Lord would call me, An' I would'nt be ready t' die. broad; But take it in your forehead, An' carry it to de Lord.

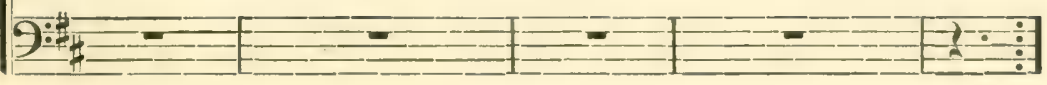




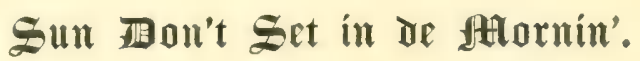

Chorus.

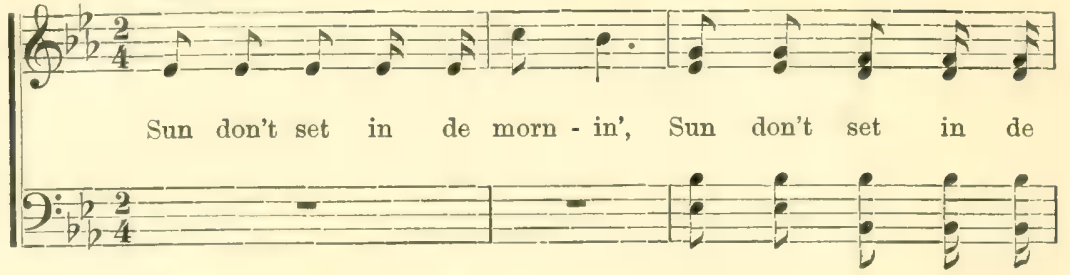

Fine.

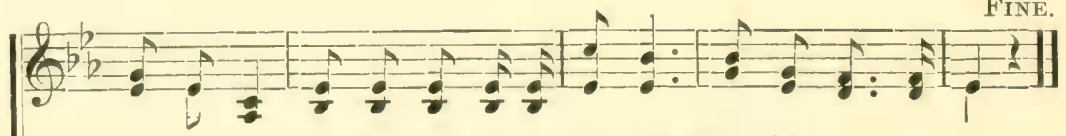
morn-in', Lord, Sun don't set in de morn-in', Lightshine round de world.
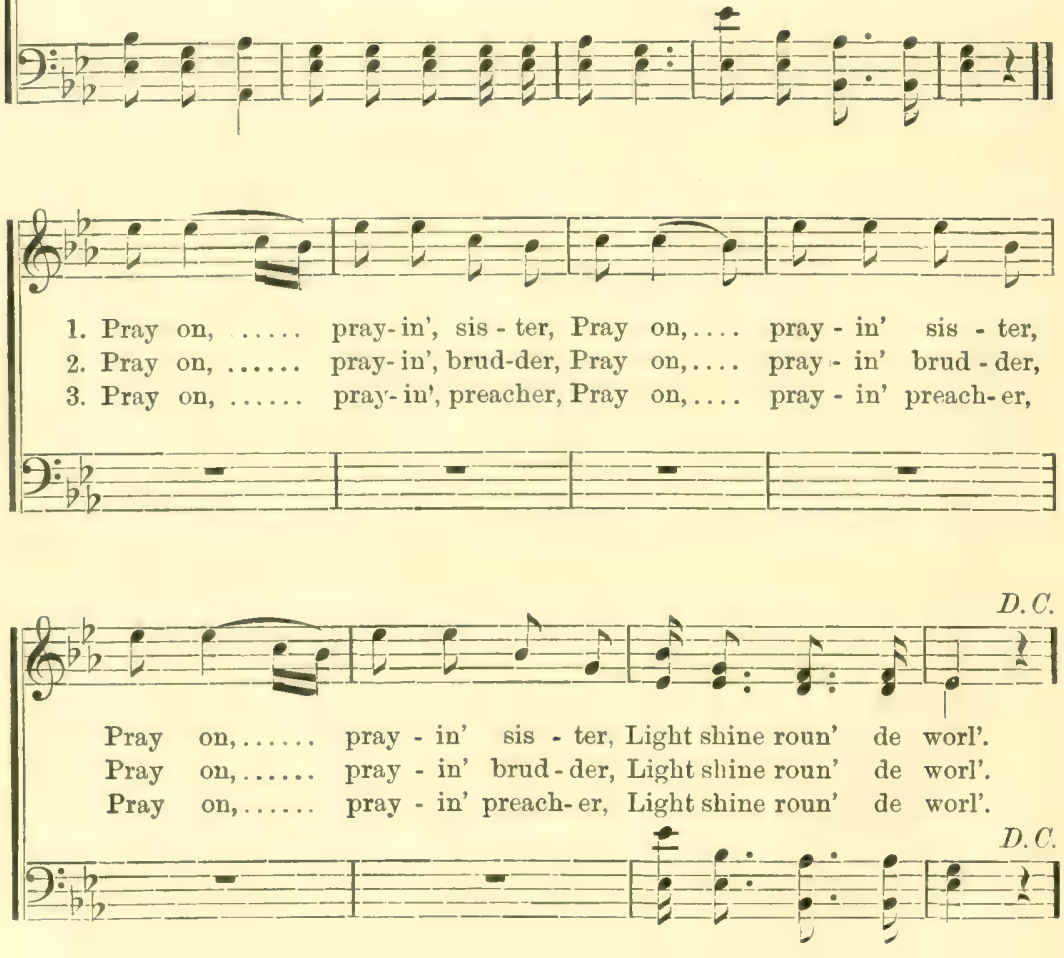


\section{Lias̆lin' Jicob.}
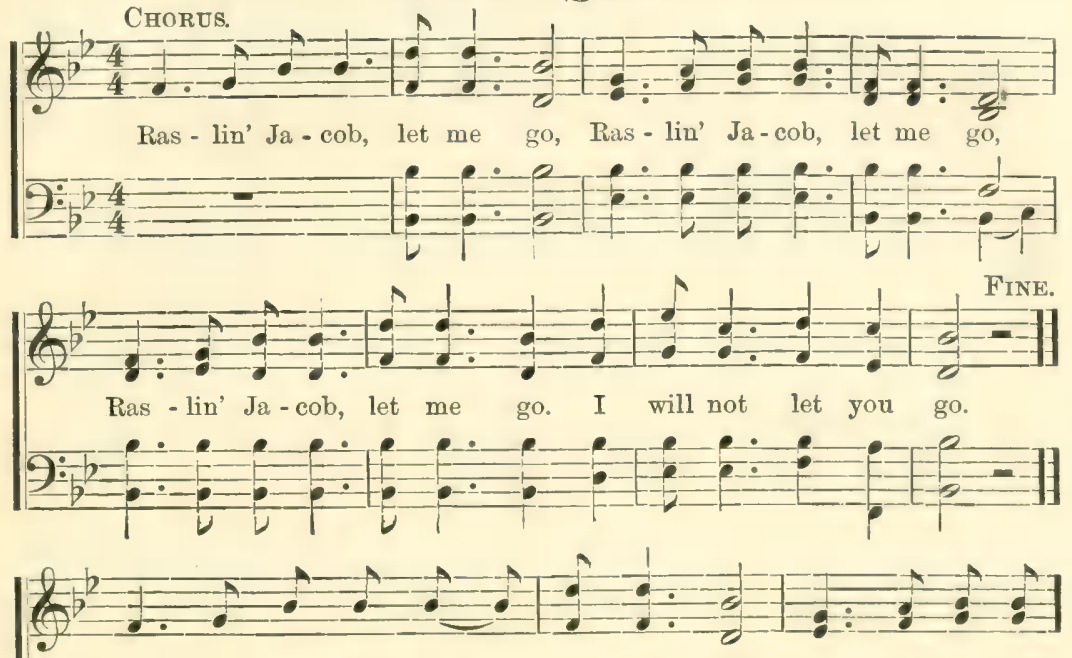

1. Day is break - in', Ja - cob, let me go, Day is break-in',

2. If you'll bless my soul, I'll let you go, If you'llblessmy

3. When I'm sink - in' down, pit - y me, When I'm sink - in'
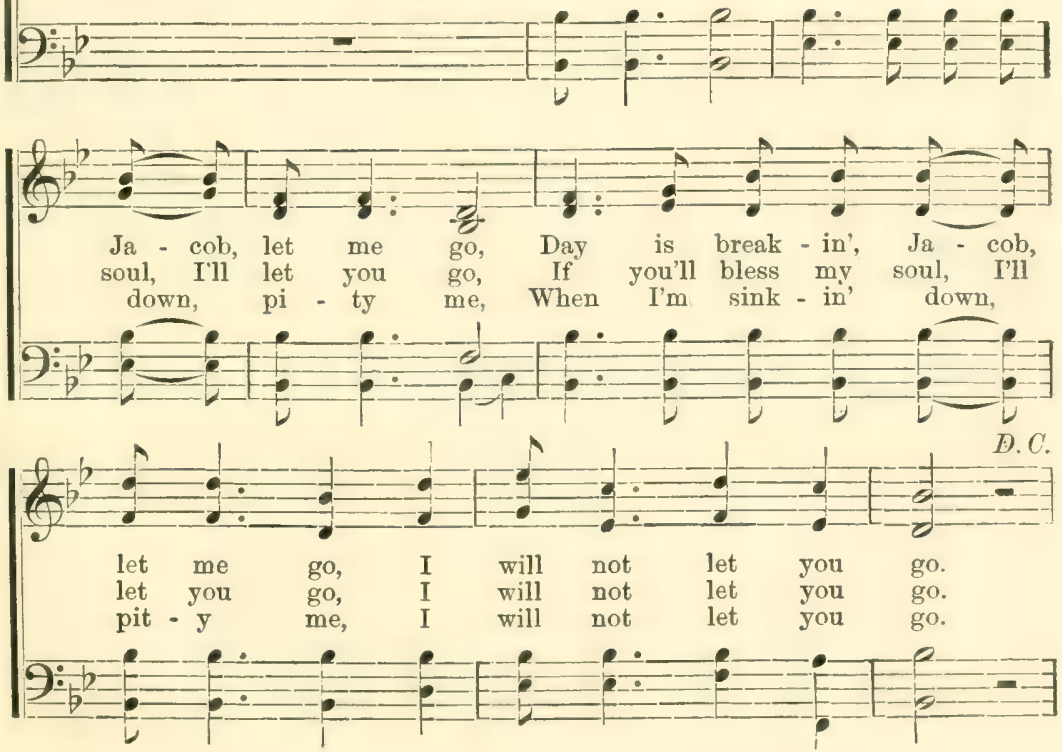


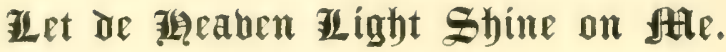
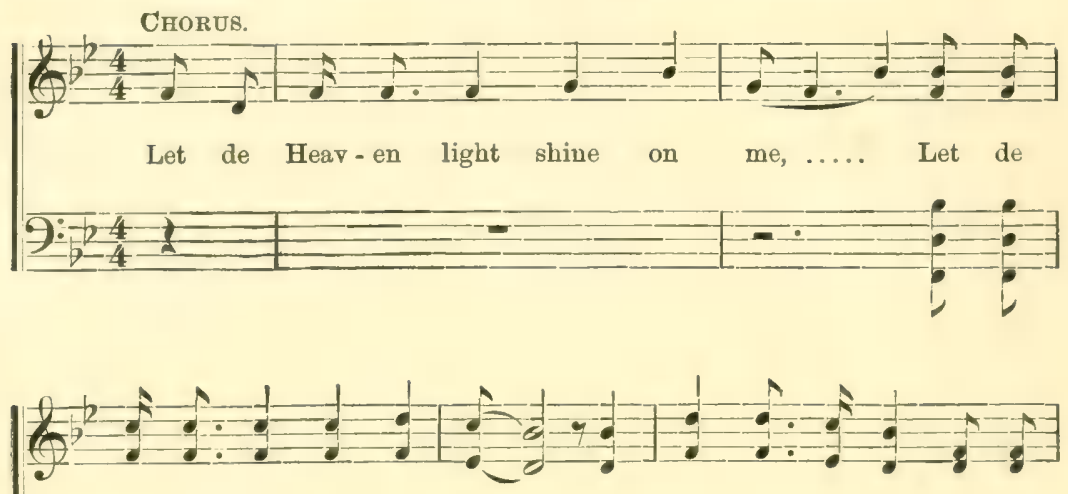

Heav - en light shine on me, For low is de way to de

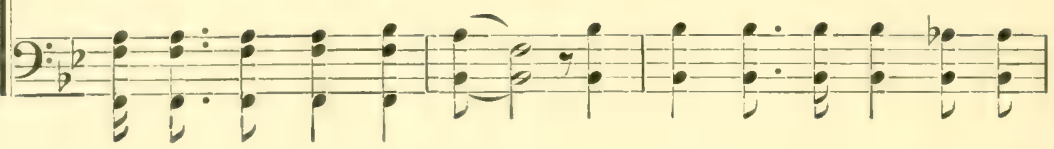

Fine.

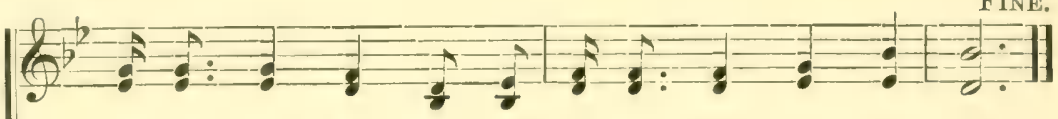

up - per bright world, Let de Heav-en light shine on me.

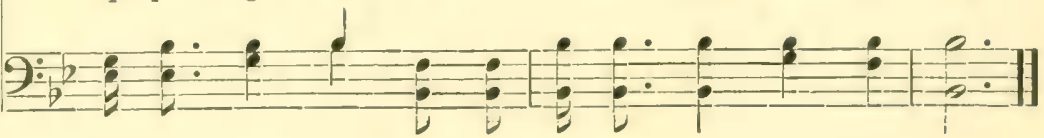

SoLo.

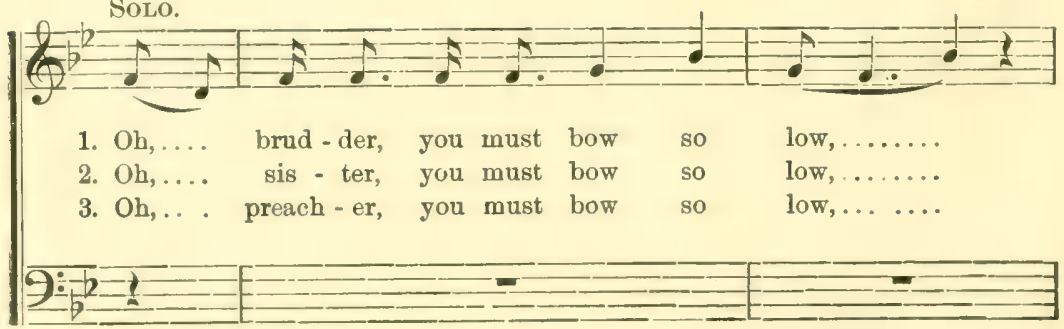




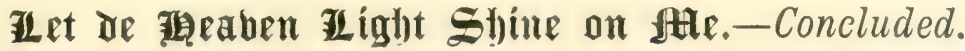

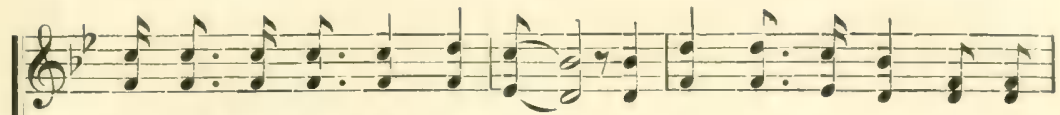

Brud-der, you must bow so low, For low is de way to de

Sis - ter, you must bow so low, For low is de way to de

Preach-er, you must bow so low, For low is de way to de
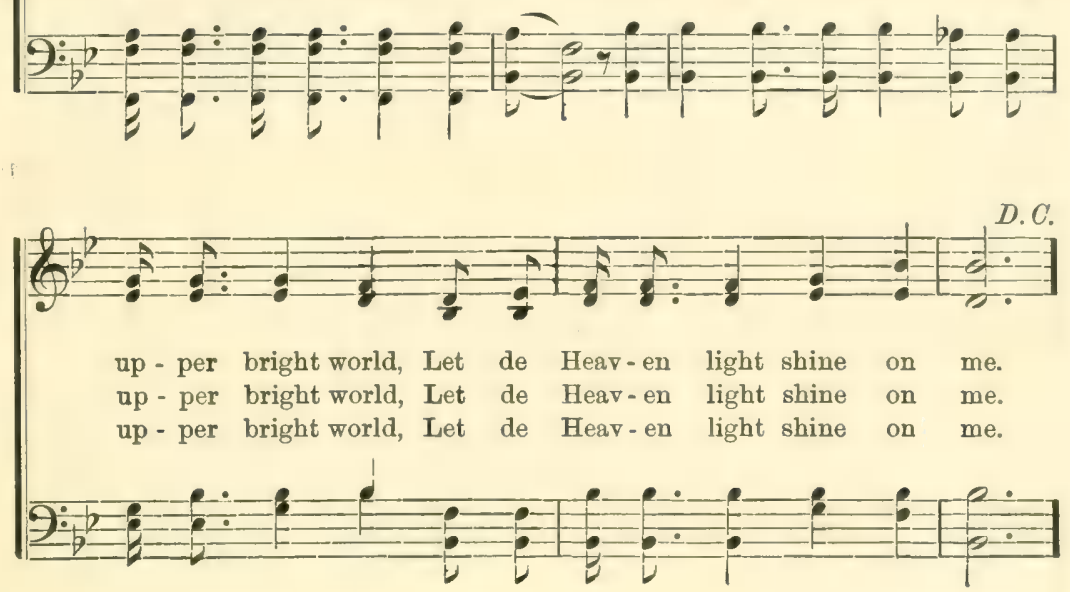

4 Class leader, you must bow so low,

Class leader, you must bow so low,

For low is de way to de upper bright world,

Let de Heaven light shine on me.

Cho.-Let de Heaven light shine on me, etc.

$5 \mathrm{Ob}$, elder, you must bow so low,

Elder, you must bow so low,

For low is de way to de upper bright world,

Let de Heaven light shine on me.

Cho.-Let de Hearen light shine on me, etc.

$6 \mathrm{Ob}$, deacon, yon must bow so low,

Deacon, you must bow so low,

For low is de way to de upper bright world,

Let de Heaven light shine on me.

Cho.-Let de Heaven light shine on me, etc. 


\section{(Eeit on Board zlittle éfildoren.}
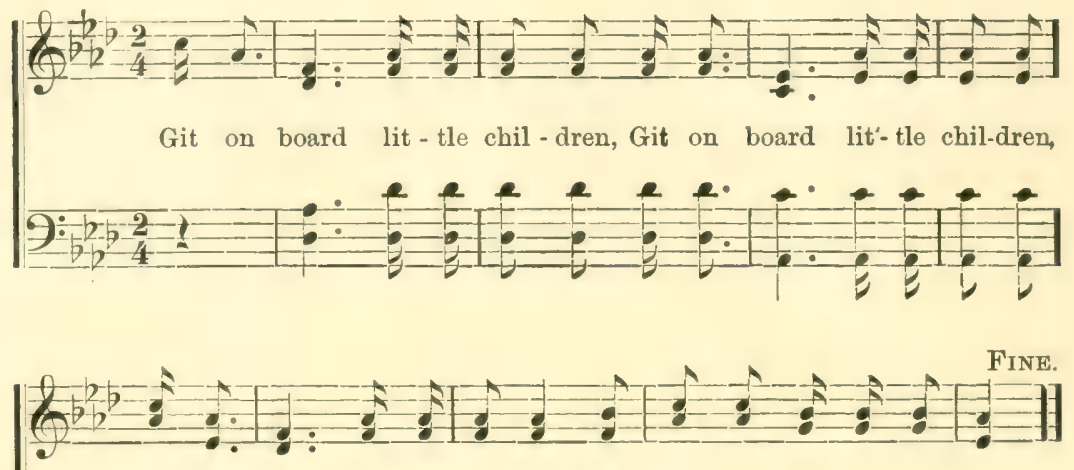

Git on board lit-tle children, Dere's room for ma-ny a mo'.
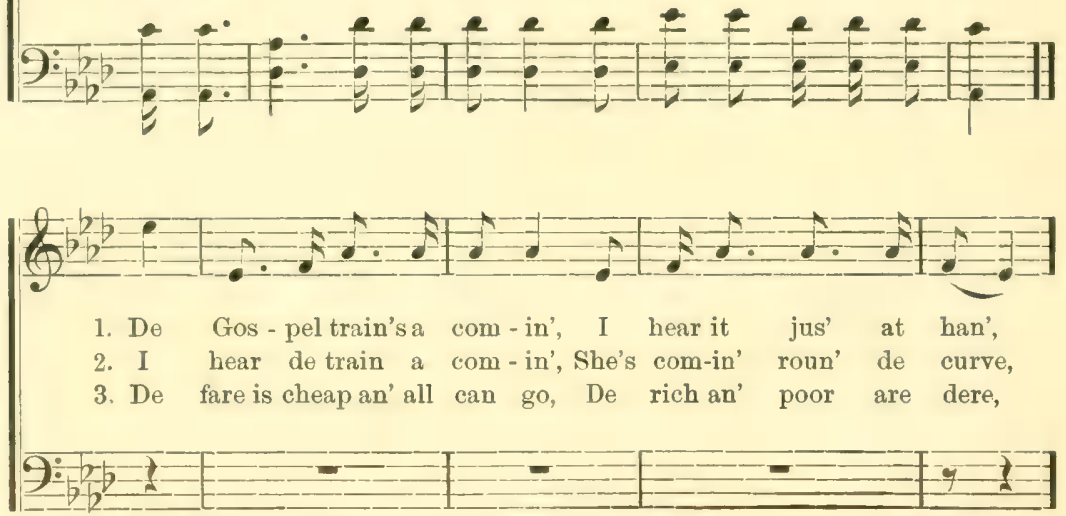

D. C

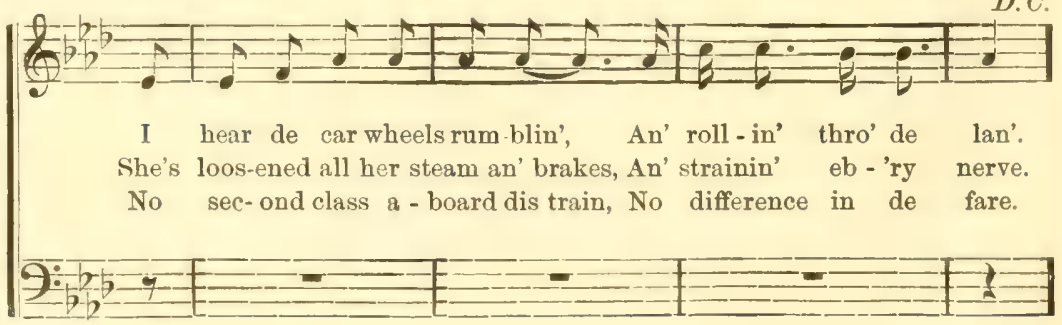




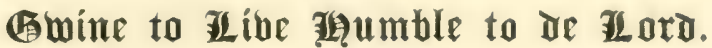

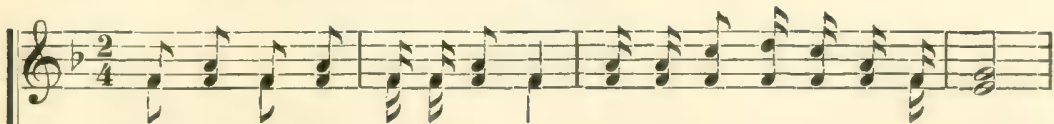

Hum. ble, humble, humble yourselves, Gwine to live hamble to de Lord,
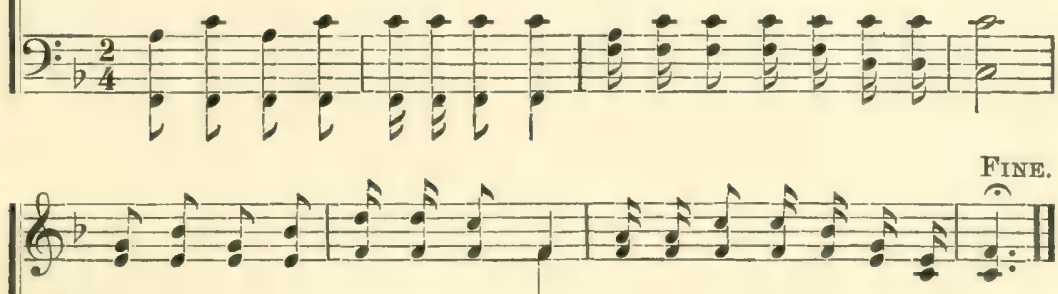

Hum-ble, hum-ble, hum-ble, yourselves, Gwine to live humble to de Lord.
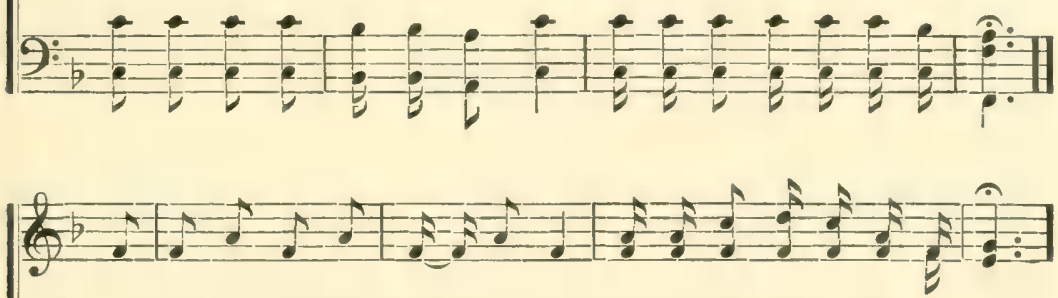

1. One day as I was walkin' a - long, Gwine to live humble to de Lord.

2. Although you see me go-in' long so, Gwine to live humble to de Lord.

3. You say you're aim-in' for de skies, Gwine to live humble to de Lord.

4. If you get there be - fore I do, Gwine to live humble to de Lord.
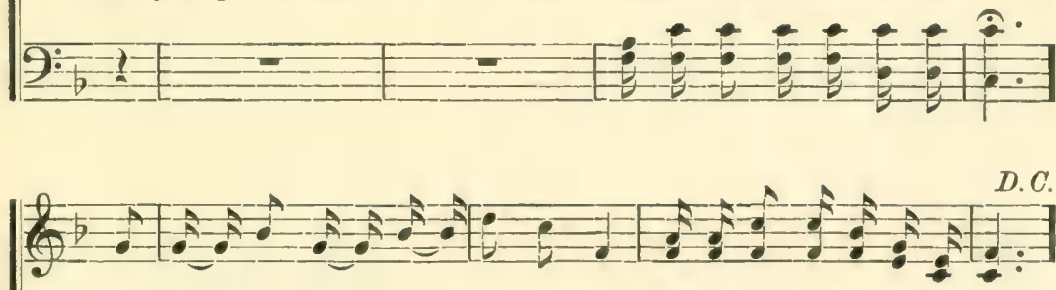

De el-ement opened an' de love came down, Gwine to live humble to de Lord.

I have my tri - als here be-low, Gwine to live humble to de Lord.

Why don't you stop that tell - in' lies? Gwine to live humble to de Lord.

Look out for me I'm com - in' too, Gwine to live humble to de Lord.

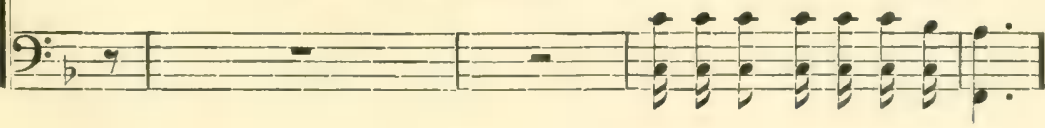




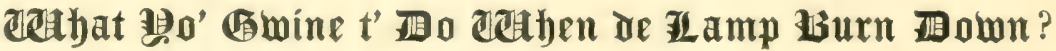

(An old Georgia Plantation Song.)

REFraIN.

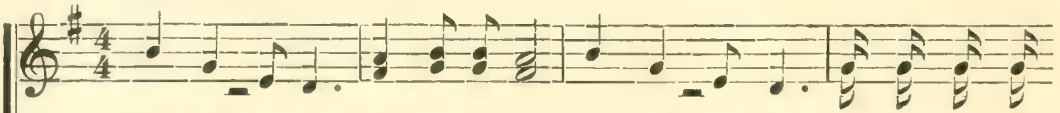

Oh, po' sinner, Now is yo' time Oh, po' sin-ner What yo' gwine to

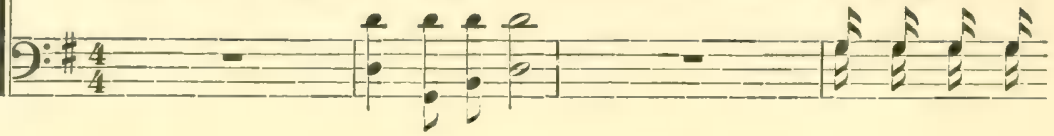

FINE.

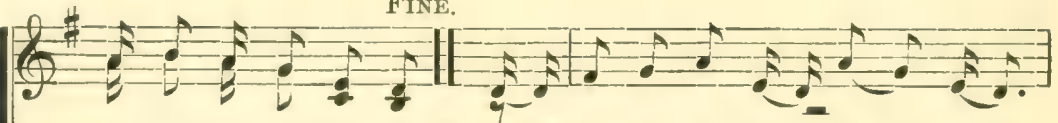

do when de lamp burn down? 1. Oh, de lamp burn down an' yo' cannot see;

2. E - ze - kiel saw dat wheel o' time;
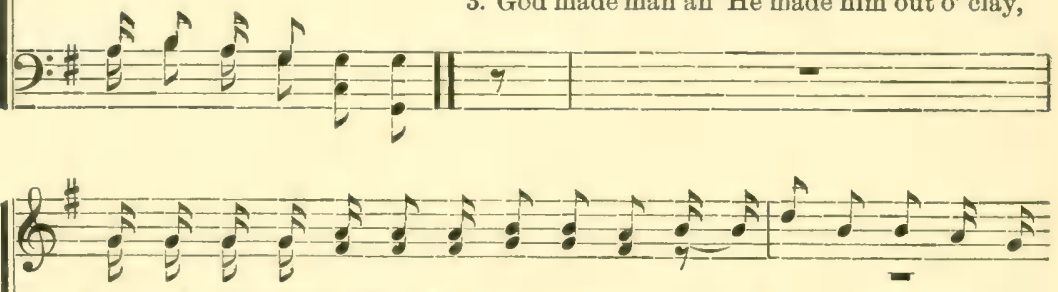

What yo' gwine t' do when de lamp burn down? Oh, de lamp burn down an' yo' What yo' gwine ' $t$ ' do when de lamp burn down? An' ev - 'ry spoke was of

What yo' gwine t' do when de lamp burn down? An' put him on de earth, but
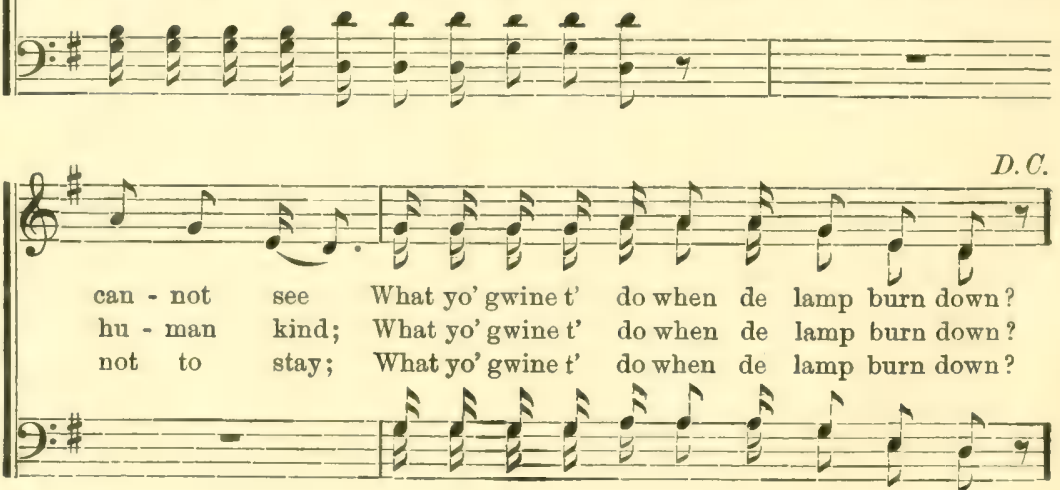


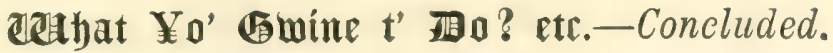

4 Dey cast ole Daniel in de lion's den;

What yo' gwine 't' do when the lawp burn down?

An' Jesus locked de lion's jaw;

What yo' gwine t' do when de lamp burn down?-Ref.

5 Ole Satan's mad an' I am glad:

What yo' gwine t' do when de lamp burn down?

He miss one soul he thought he had,

What yo' gwine t' do when de lamp burn down?-Ref.

6 Ole Satan's a liar an' a conjurer too;

What yo' gwine t' do when de lamp burn down?

If yo' don't mind, he slip it on yo'

What yo' gwine t' do when de lamp burn down?-Ref.

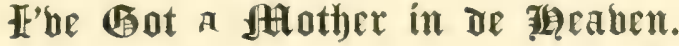
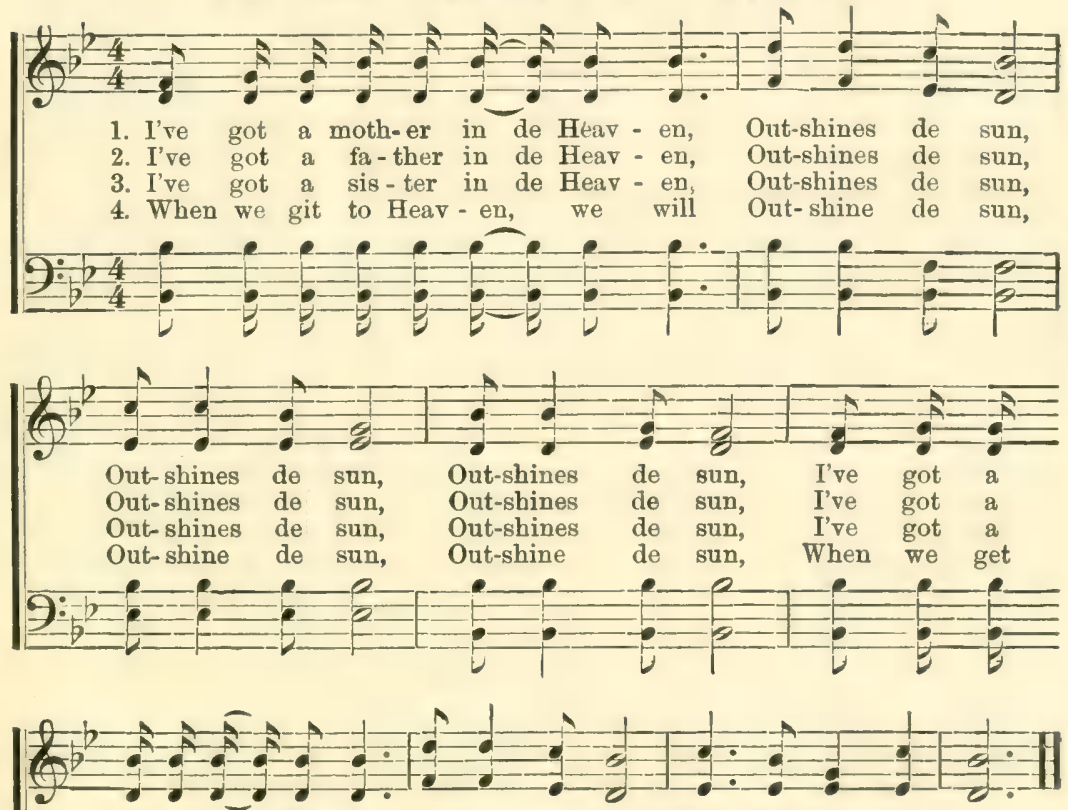

mother in de Heaven, Outshiues de sun, Way be-yond de moon. father in de Heaven, Outshines de sun, Way be-yond de moon. sis-ter in de Heaven, Outshines de sun, Way be-yond de moon. to Herv-en, we will Out-shine de sun, Way be-yond de moon.

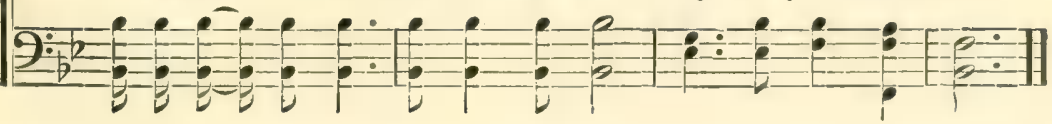




\section{Crome 国own, Sinnex.}

(An old Plantation Song in common nse in Gloucester County, Va.)
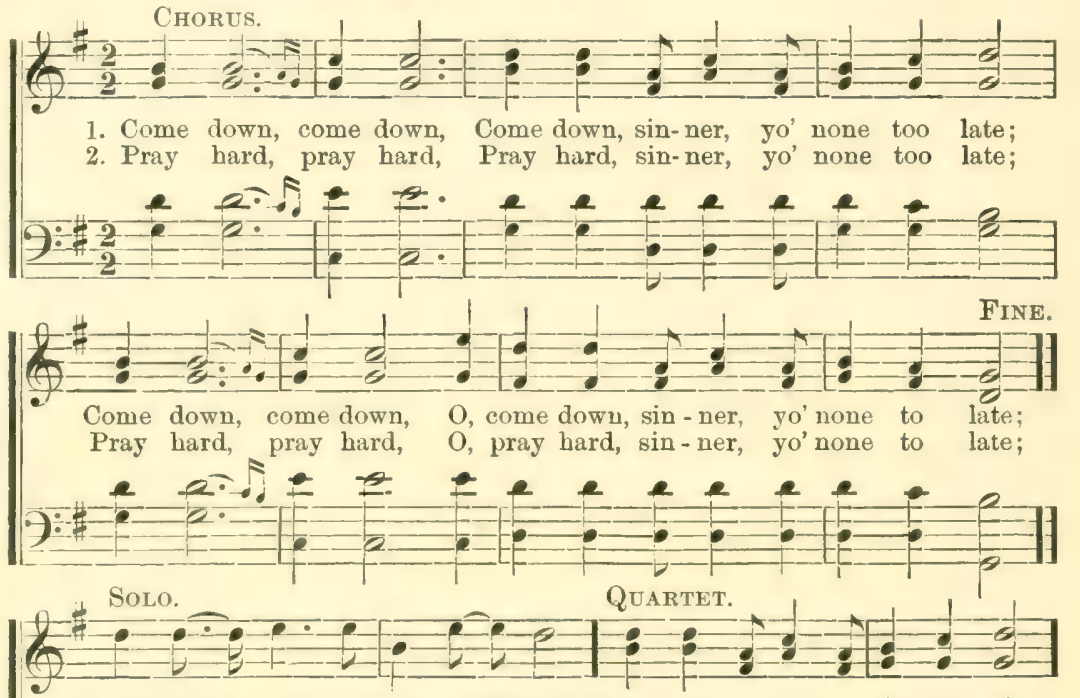

Some seek de Lord, but doan seek Him right, Come down, sinner, yo' none too late;

Times ain't like dey used to be, Comedown, sinner, yo' none too late;
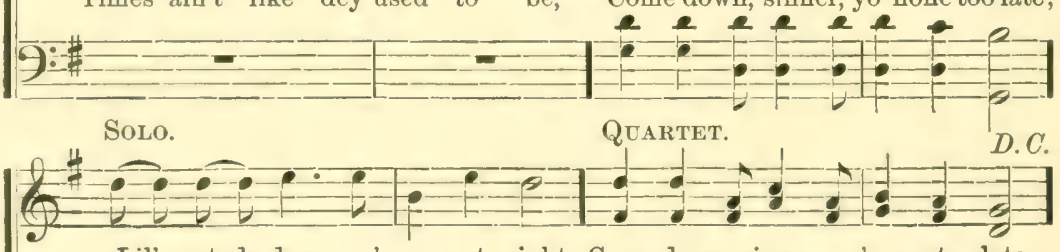

Lil' at de day an' none at night; Come down, sinner, yo' none too late.

I fo' yo' an' yo' fo' me; Come down, simner, yo' none too late.

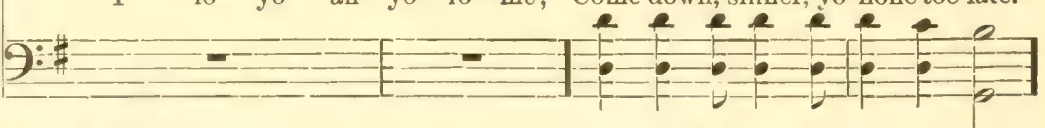

$3 \|$ : Bow low, bow low,

Bow low, sinner, yo' none too late: :

Wen' down de hill t' say my prayer,

Come down, sinner, yo' none too late;

When I got dere, ole Satan was dere,

Come down, sinner, yo' noue too late.

4 || : Seek hard, seek hard,

Seek hard, siuner, yo' none too late; :\|

What do yo' tink ole Satrn say?

Come down, sinner, yo' none too late;

"Jesus dead, an' God gone away,"

Come down, sinner, yo' none too late.
5 || : Shout hard, shout hard,

Shout hard, sinner, yo' none too late; :\|

What t' do, I did not know,

Come down, sinner, yo' none to late;

Right back home I had to go,

Come down, sinner, yo' none too late.

$6 \|$ : Mourn hard, mourn hard,

Mourn hard, sinner, yo' none too late ; :l

Something spoke unto my soul,

Come down, sinner, yo' none too late;

"Go in peace, an' sin no mo',"

Come down, sinner, yo' none too late. 


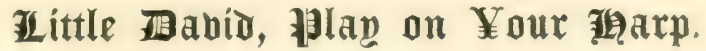

CHORUs.

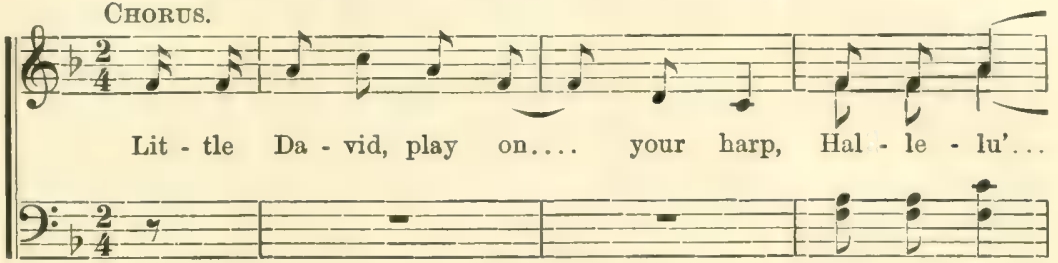

Hal - le - lu.'

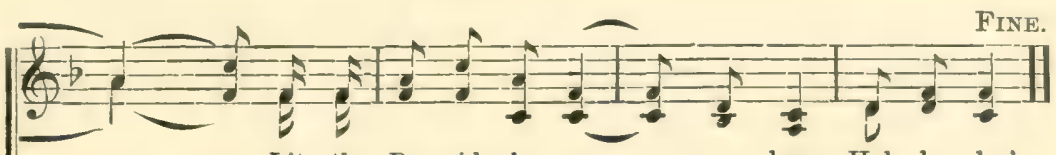

............. Lit - tle Da-vid play on... your harp, Hal - le - lu.'
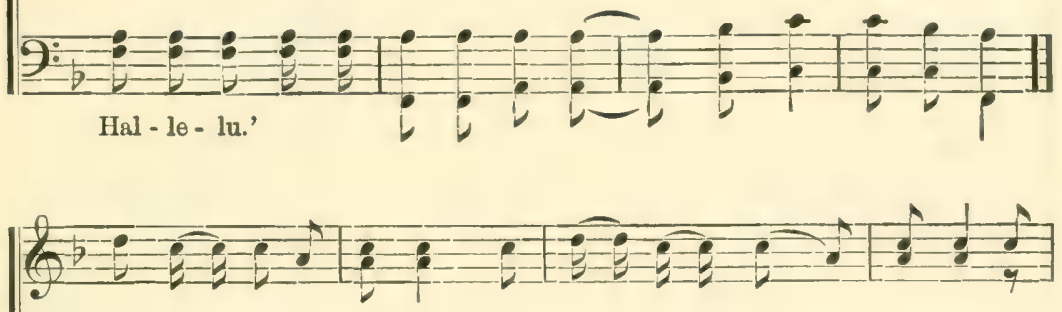

1. God told Mo-ses, O Lord! Go down in-to E-gypt, O Lord!

2. Down in de val-ley, O Lord ! Did-n't go t' stay, O Lord! My

3. Come down an-gels, O Lord! With ink an' pen, O Lord! An'

$9: \frac{2 \pm}{2}$

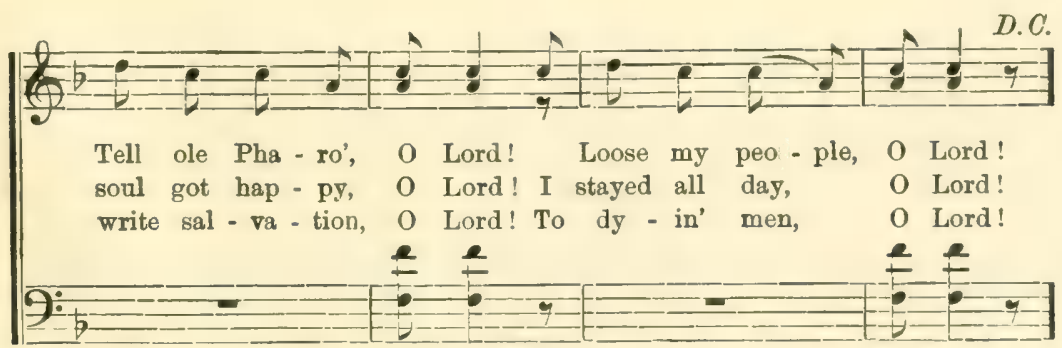




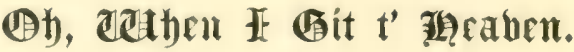

\author{
(Old Plantation Song from Alabama.)
}
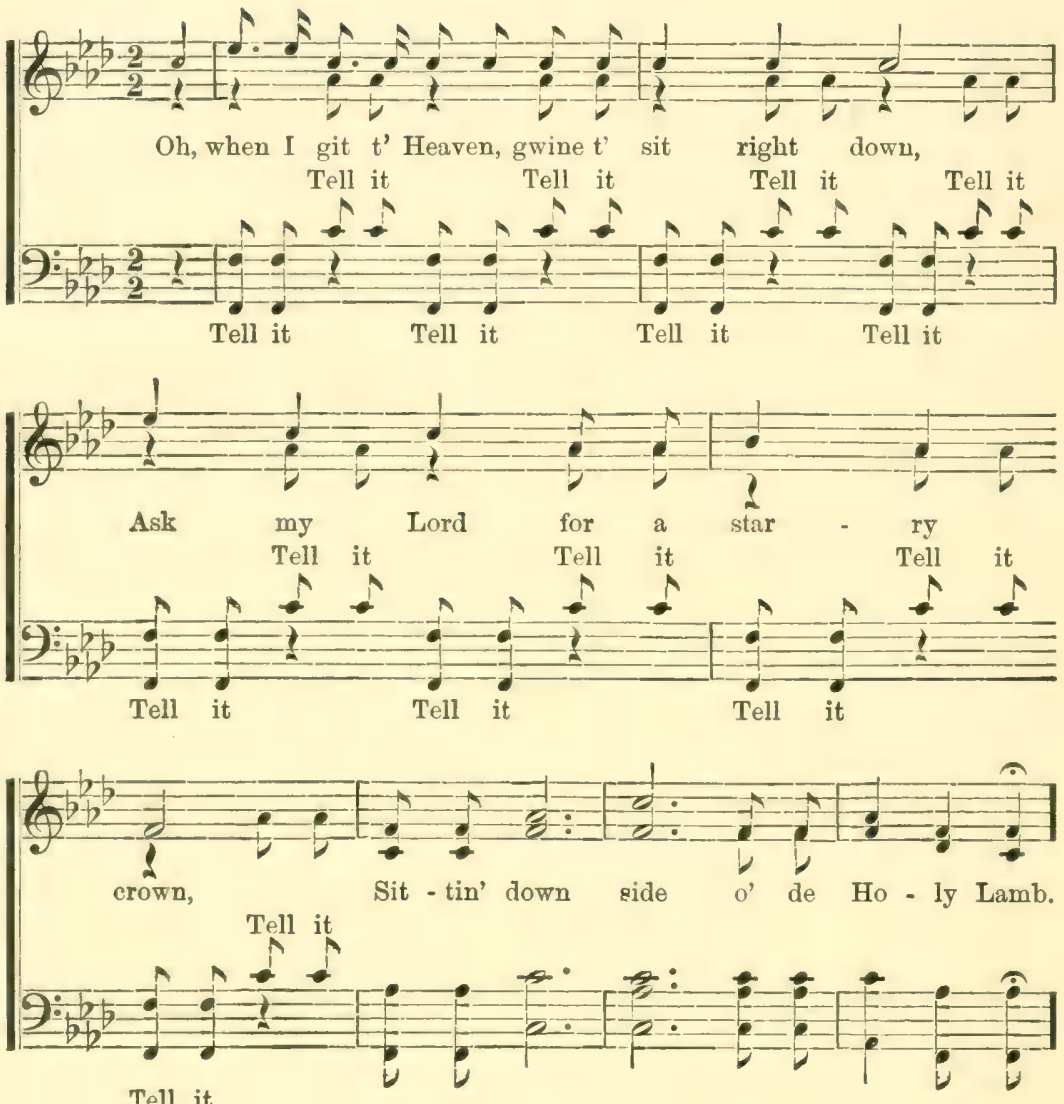

Tell it

REFrain.

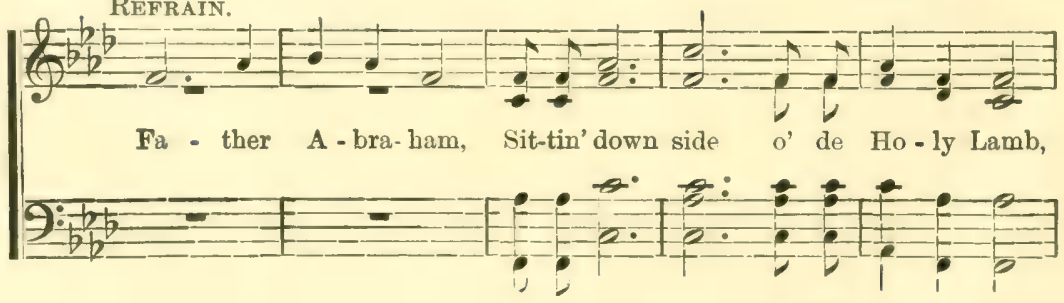




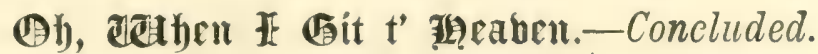

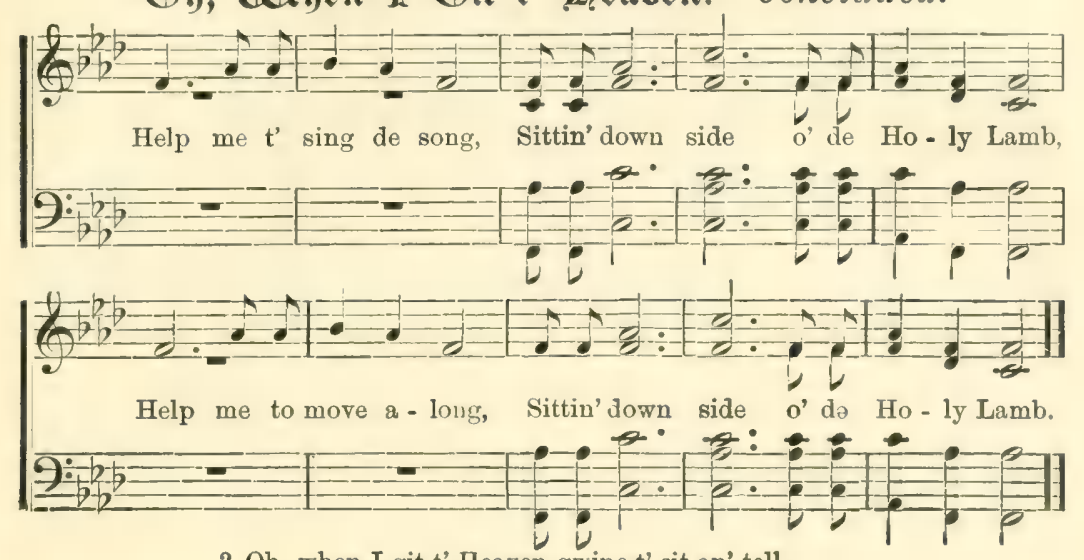

$2 \mathrm{Oh}$, when I git t' Heaven gwine t' sit an' tell,

Three archangels gwine t' ring dem bell,

Sittin' down side o' de Holy Lamb.-Ref.

$3 \mathrm{Oh}$, when I git t' Heaven gwine t' ease, ease,

Me an' my God gwine t' do as we please,

Sittin' down side o' de Holy Lamb.-Ref.

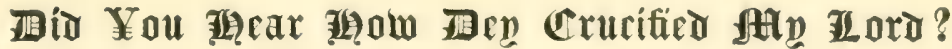

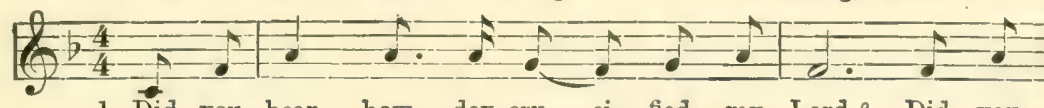

1. Did you hear how dey cru - ci - fied my Lord? Did you

2. Did you hear bow He hung on de cross? Did you
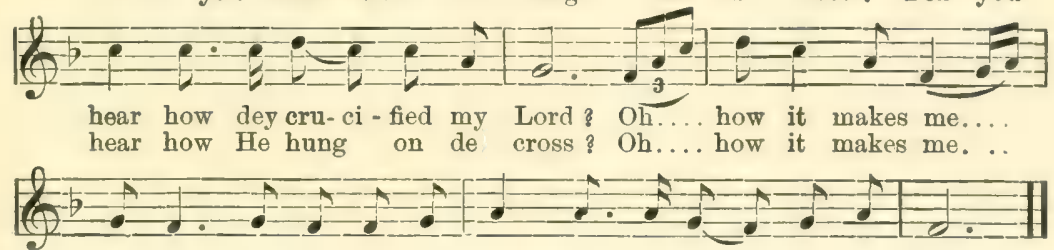

trem-ble, trem-ble, Did you hear how dey cru-ci-fied my Lord?

trem-ble, trem-ble, Did you hear how He hung on de cross?

\|: 3 Did you hear how He groaned, bled an' died? :\|

Oh, how it makes me tremble. tremble,

Did you hear how he groaned, bled an' died?

I: 4 Did you hear how dey laid Him in de tomb? :॥

Oh, how it makes me tremble, tremble,

Did you hear how dey laid Him in de tomb?

I: 5 Did you hear how He rose from de grave, :\|

$\mathrm{Ob}$, how it makes me tremble, tremble,

Did you bear how He rose from de grave? 


\section{E'be bisen Coillin' at דe mgill.}
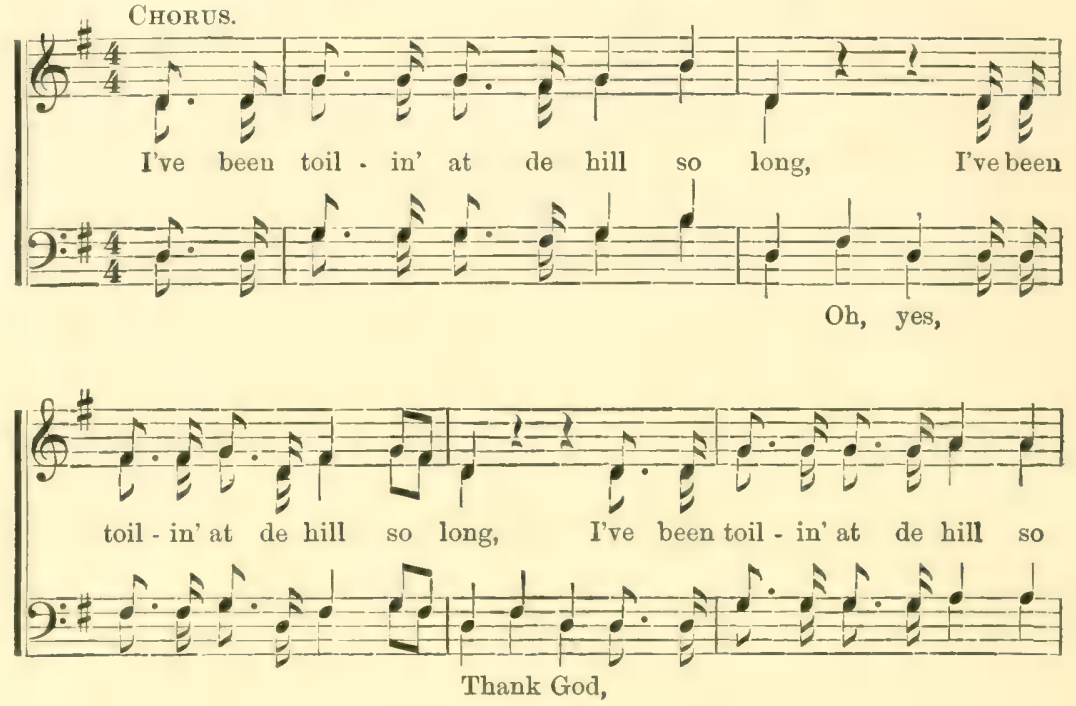

Fine.
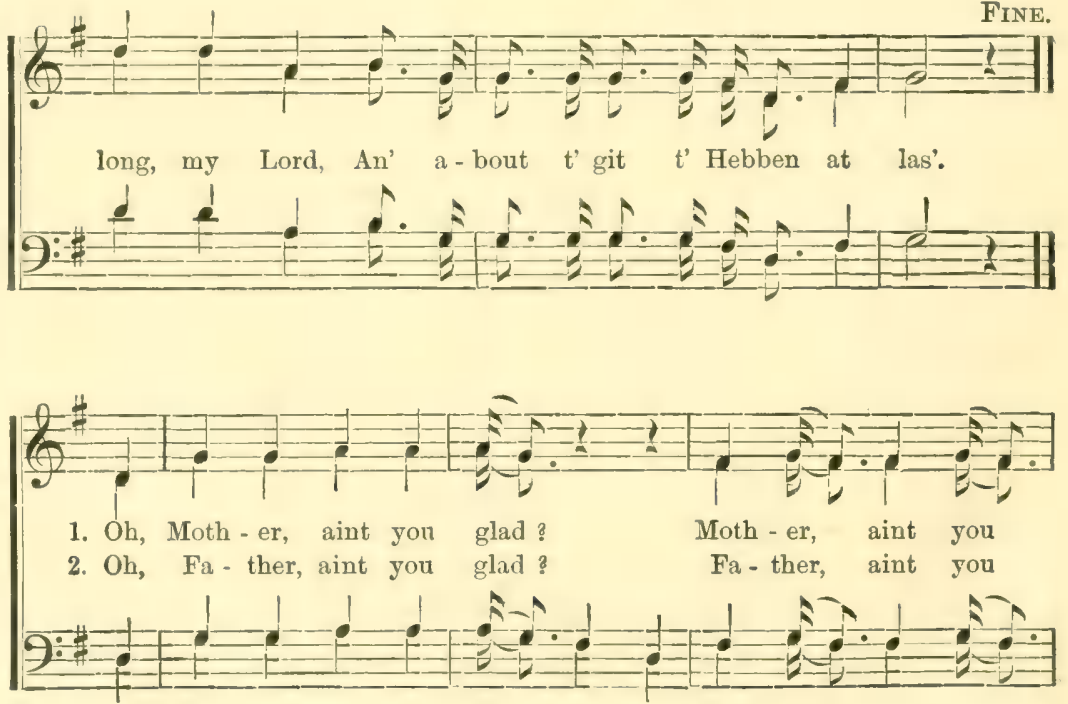

$\mathrm{Oh}$, yes, 


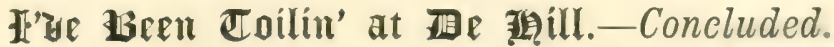

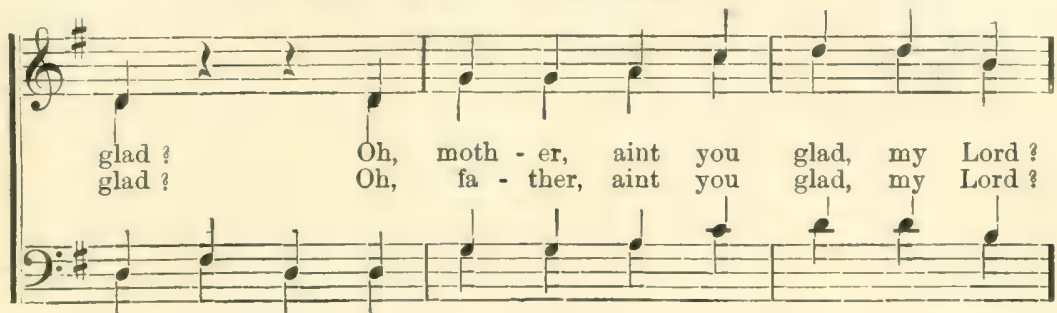

Thank God,

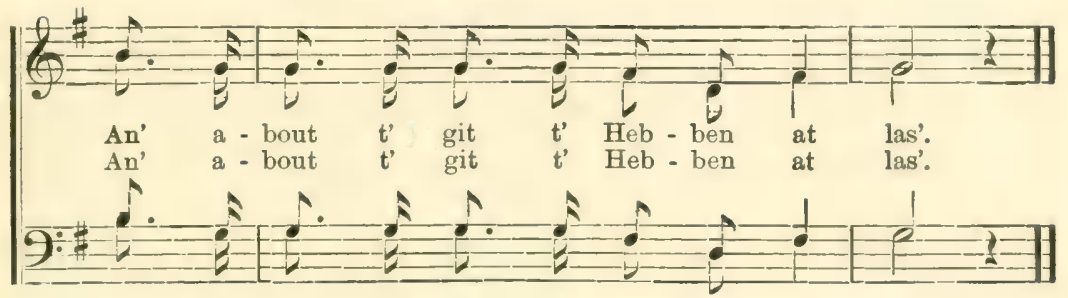

$3 \mathrm{Ob}$, sister. aint you glad?

Sister, aint you glad?

$\mathrm{Oh}$, sister, aint you glad, my Lord \&

An' about t' git t' Hebben at las'.
$4 \mathrm{Oh}$, brother, aint you glad? Brother, aint you glad?

Oh, brother, aint you glad, my Lord? An' about t' git t' Hebben at las'.

\section{Grace Bafore steat at Glampton.}

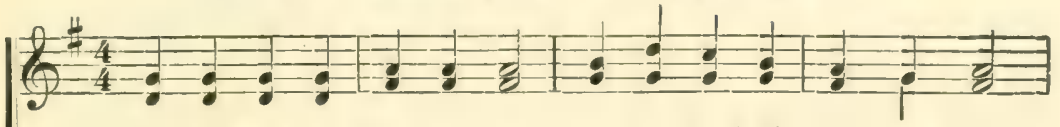

Thou art great and Thou art good, And we thank Thee for this food;
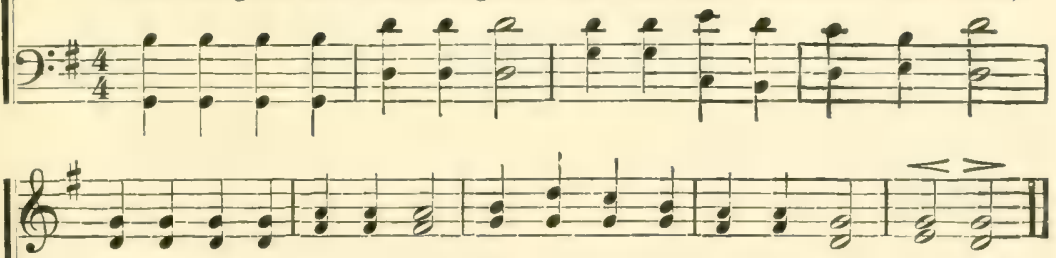

By Thy hand must we be fed, Give us Lord our dai-1y bread. A-men.

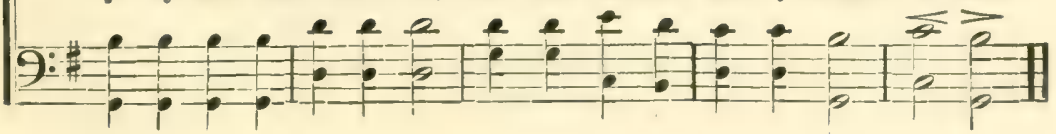




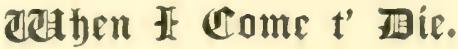

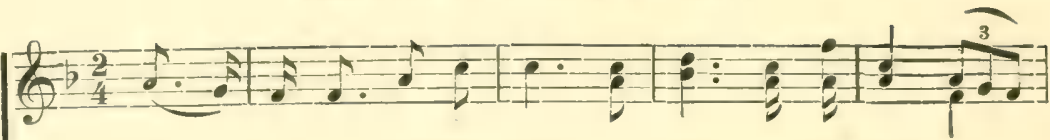

1. Oh, when I come t' die, I wan' t' be read - y,

$9:-2=1 \pm 10$

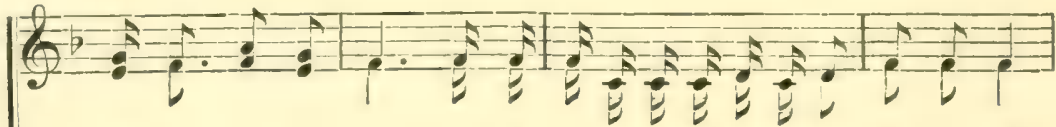

When I come t' die, Wan' t' walk about Je-ru-sa-lem jus' like Job.
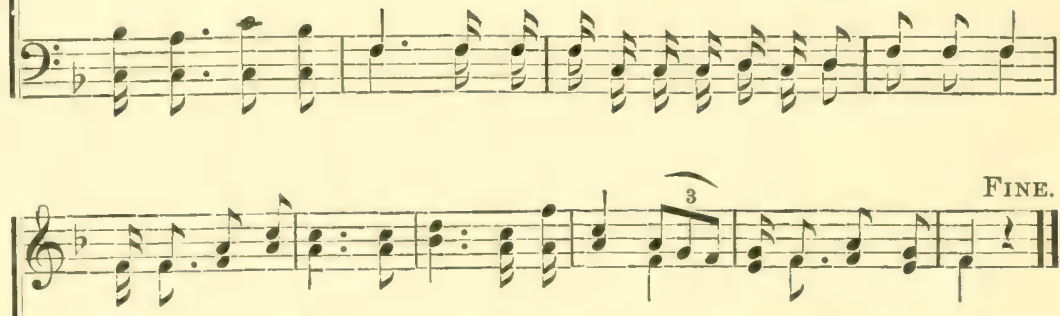

When I come t' die, I wan' $t$ ' be read-y, When I come $t^{\prime}$ die.
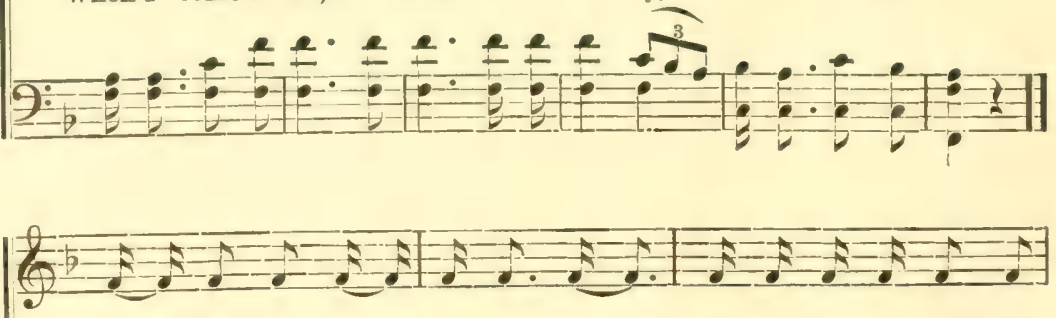

1. When I git dere I will sit down an'tell, Tell $a$-bout de world I

2. Walk a-bout Heb-ben an' car-ry de news, Tell $a$-bout de world I

3. I'll skip 'round Hebben an' car - ry de news, Tell a-bout de world I

4. Chris - tian, Chris - tian be en - gaged, Ole Sa-tan's git-tin' in a

9:- 


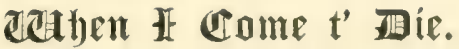

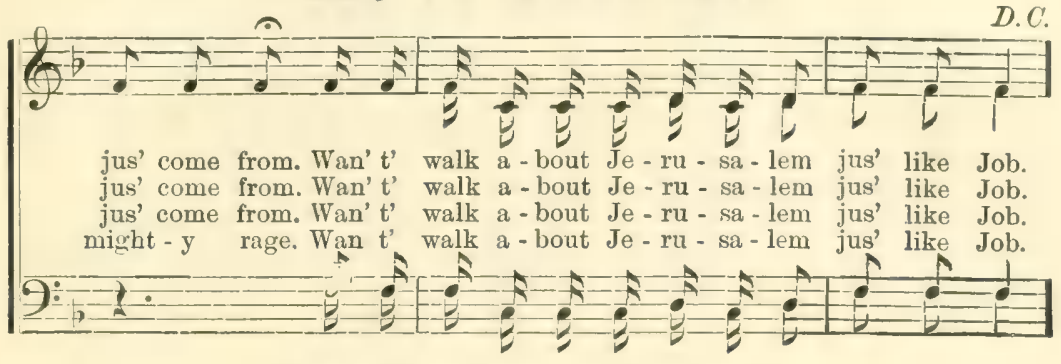

\section{The JEnlisted Soldicrs.}

(Sung by the men of he U. S. Colored Volunteers.)

NOTE.-While recruiting and drilling the 9th. Regiment, U. S. Colored troops at Benedict, Maryland, in the winter of $1863-64$, the men gathered around the camp-fire would sing by the hour the melodies of the plantation slave ife that they had just left-not always very melodious; but late one evening I was startled by a magnificent chorus from nearly a thousand black sol. diers, that called me from my tent to listen to its most inspiring strains, and I caught the following words which I culled the "Negro Battlo Iymn." S. C. ARMSTrong.
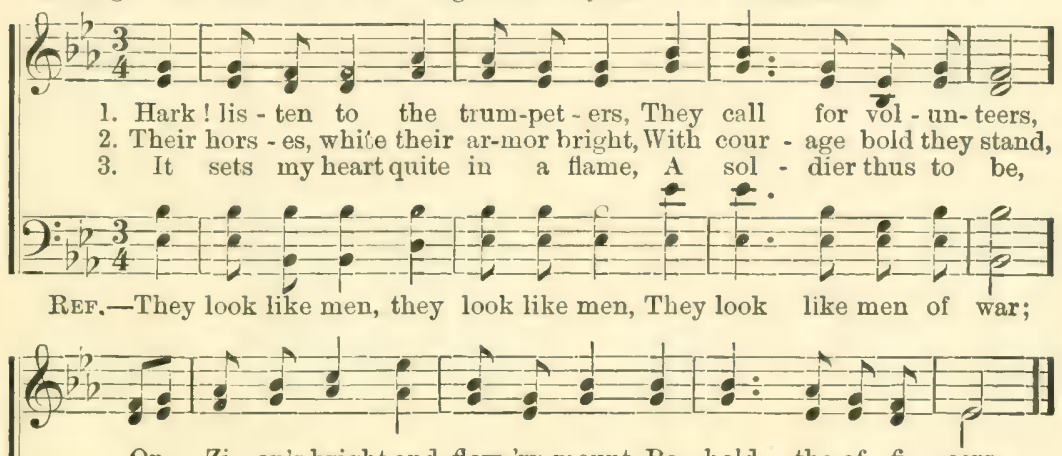

On Zi - on's bright and flow-'ry mount, Be - hold the of - $f$ - cers.

En - list-ing sol-diers for their King, To march to Canaan's land.

I will en-list, gird on my arms, And fight for lib-er - ty.

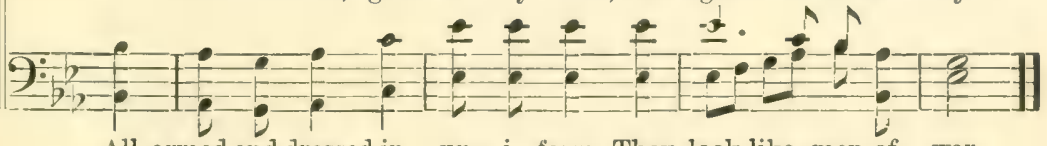

All armed and dressed in un - i - form, They look like men of war.

4 We want no cowards in our band,

That will their colors fly;

We call for valiant hearted men,

Who're not afraid to die.-Ref.

5 To see our armies on parade.

How martial they appear,

All armcd and dressed in uniform,

They look like men of war - Ref.
6 They follow their great General, The great Eternal Lamb,

His garment stained in His own blood, King Jesus is His name.-Ref.

7 The trumpets sound, the armies shout, They drive the host of Hell,

How dreadful is our God to adore, The great Immanuel.-Ref. 


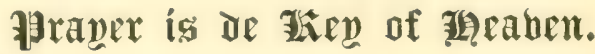

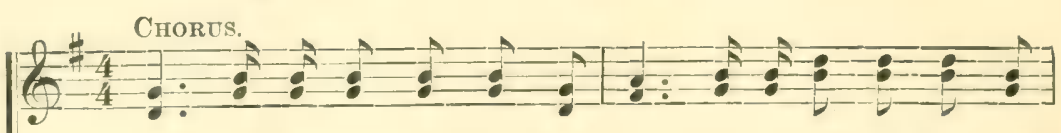

Prayer is de key of Heav-en, Prayer is de key of Heav-en,

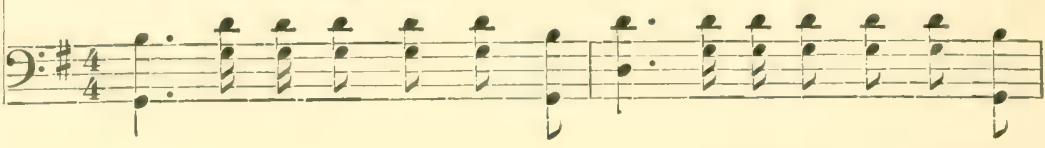

Fine.

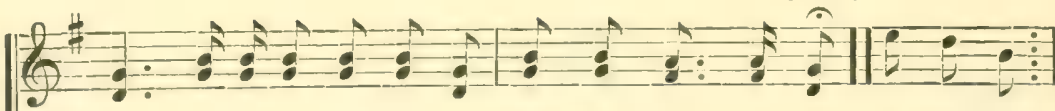

Prayer is de key of Heav-en, Faith un-locks de do' I know dat.
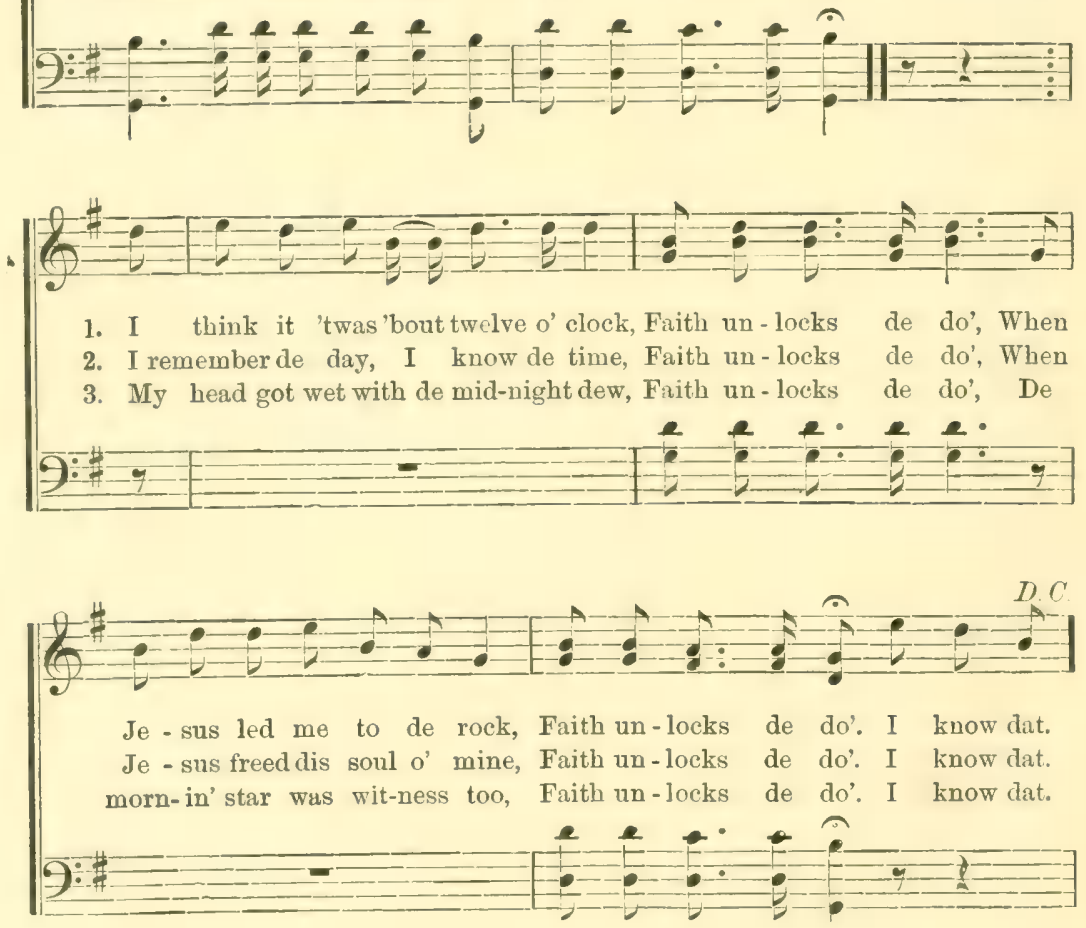


\section{Aty Soul}

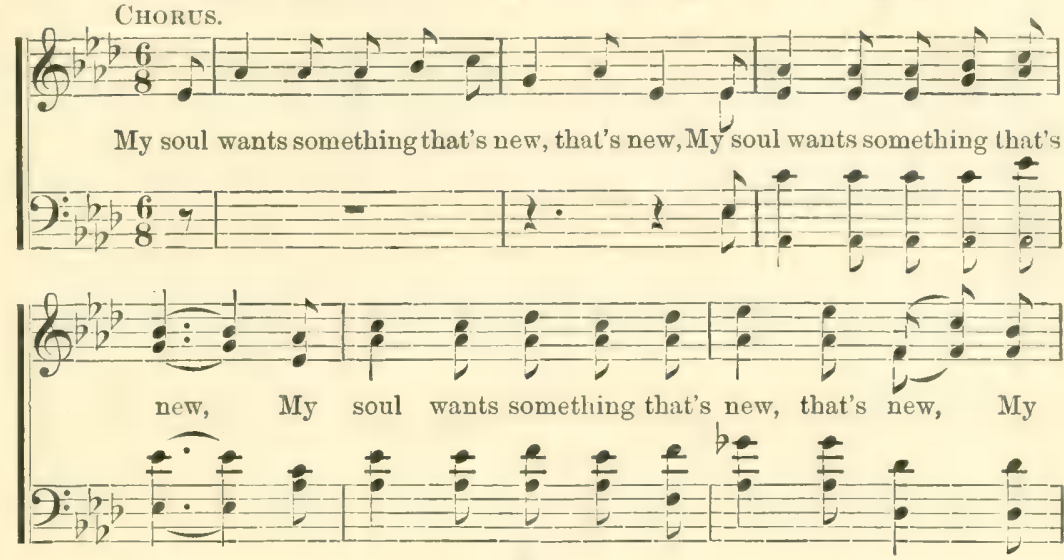

Fine.

$\left(02 a^{2}=1\right.$ soul wants something that's new. 1. Dark was the night and $2 \div 2: 5$. Was it for crimes that

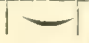

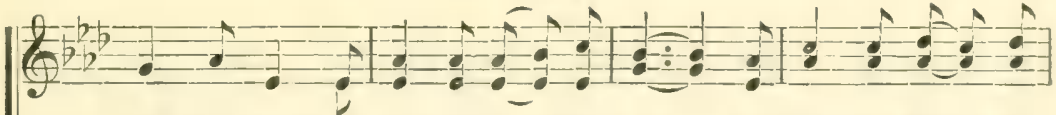
cold the ground, On which the Lord was laid, His sweat like drops of I had done, Hegroaned upon the tree? A - maz-ing pi - ty,

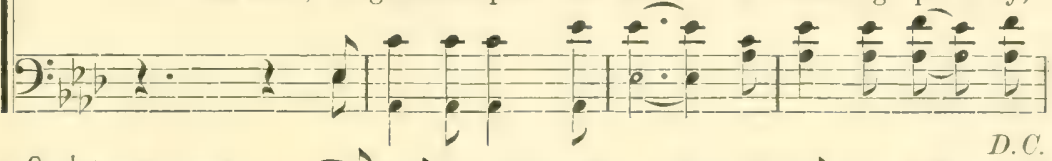

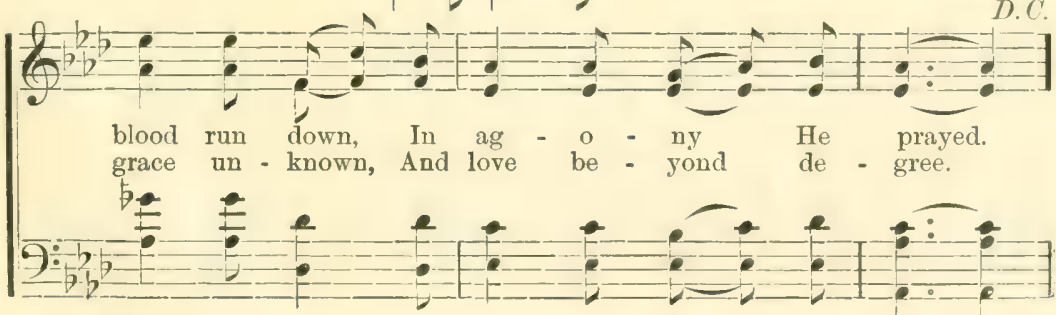




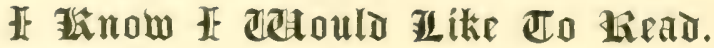

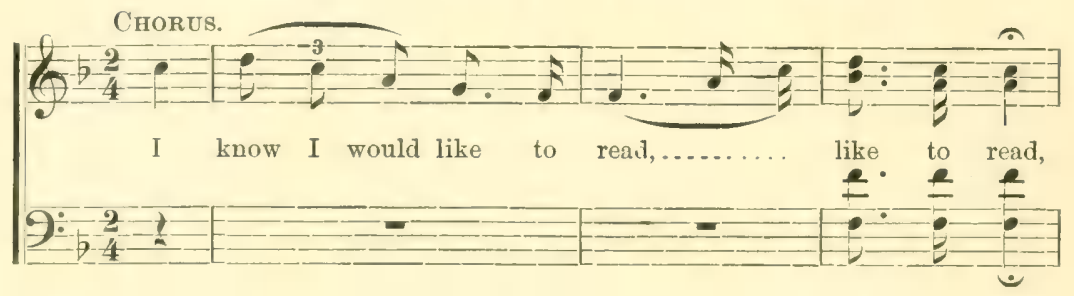

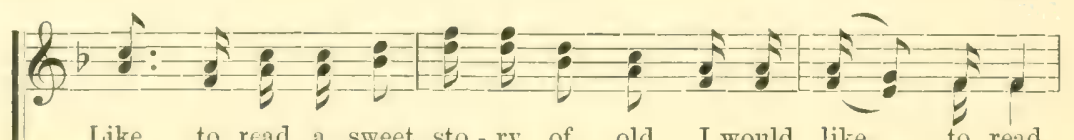

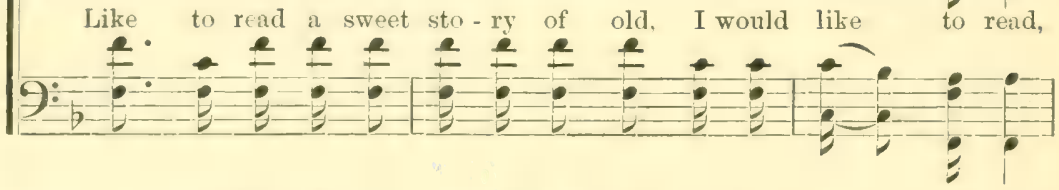

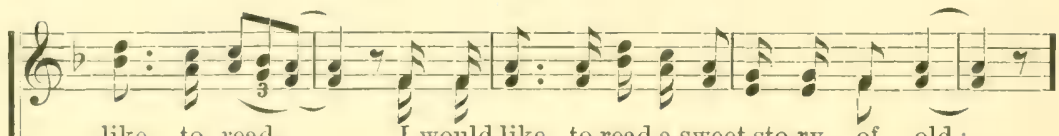
vilike tor vall

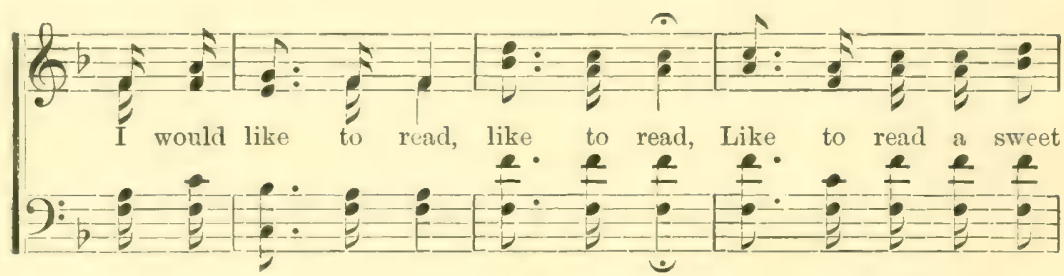

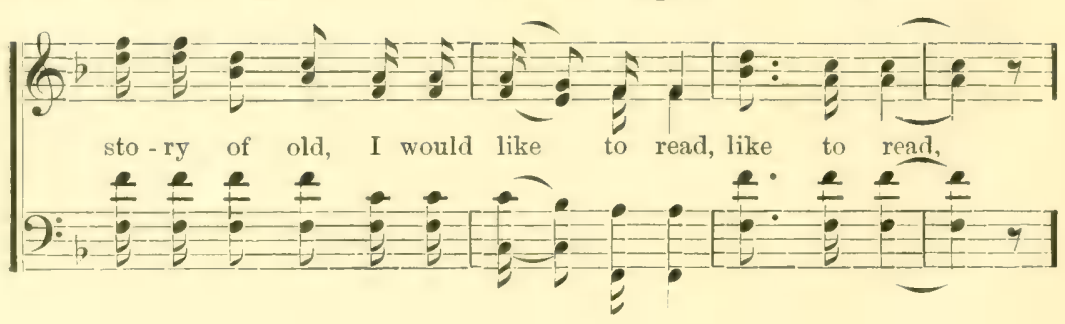




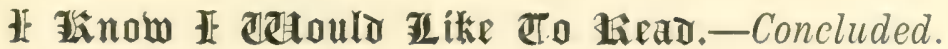
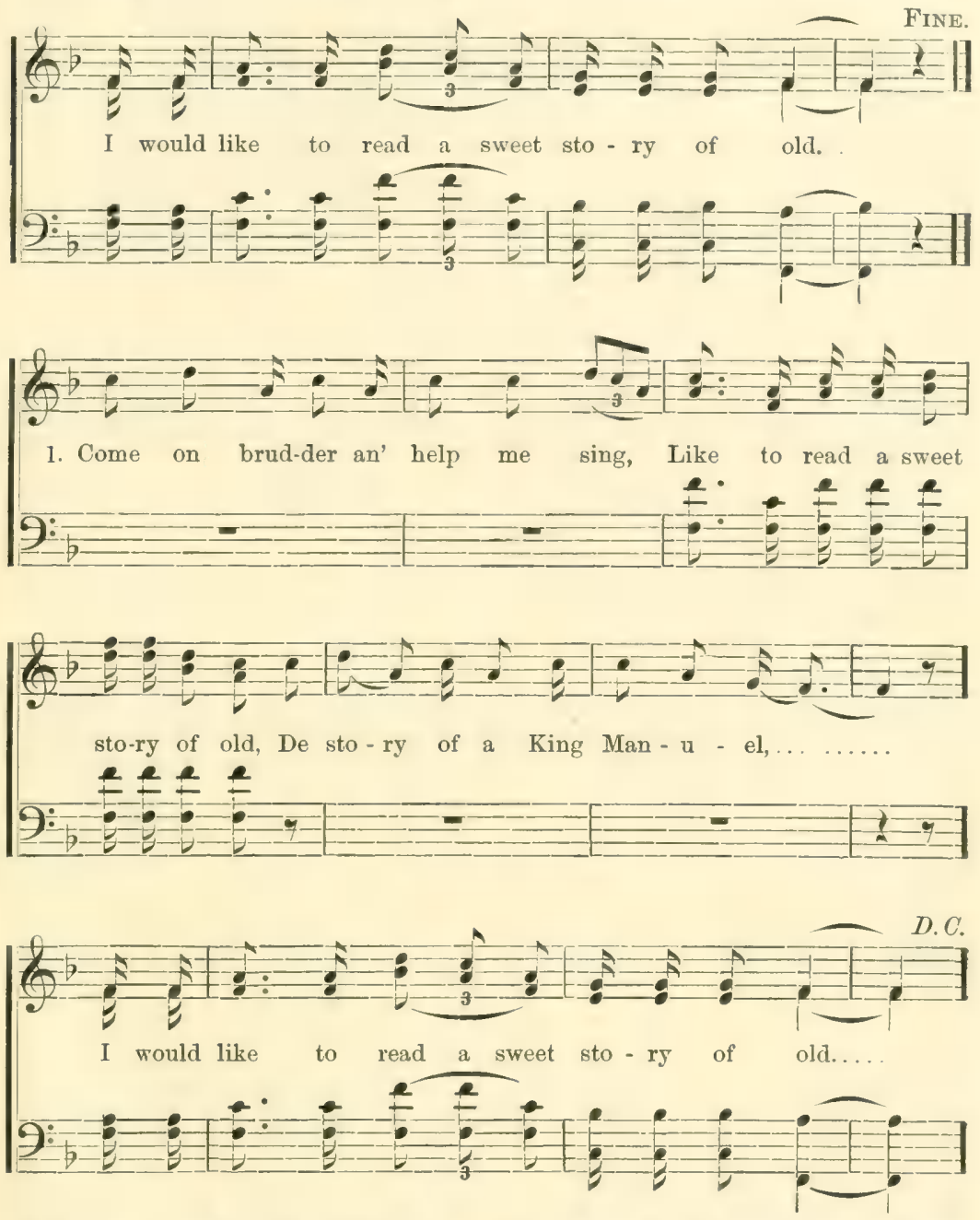

2 If ebber I get up on de other sho' Like to read a sweet story of old.

By de grace of God I'll come here no mo' I would like to read a sweet story of old.
3 I des wan' to get up on de mountain top, Like to read a sweet story of old.

I'll praise my God an' nebber stop, I would like to read a sweet story of old. 


\section{Jon't ceall ge lioll.}

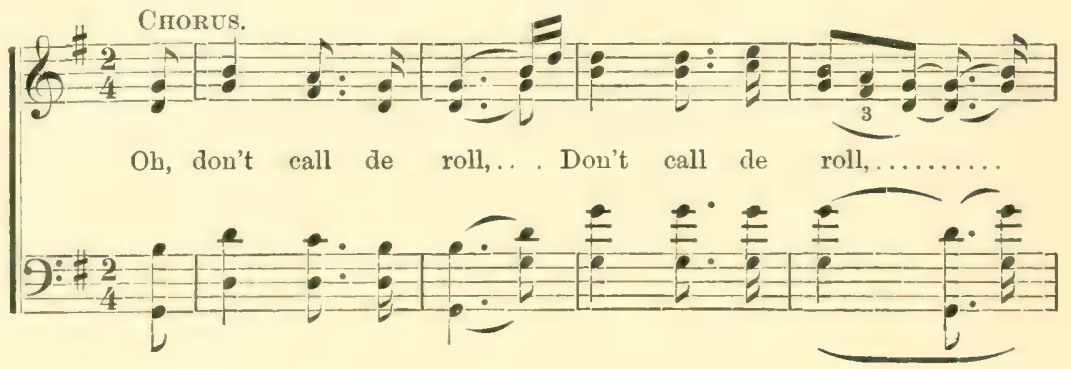

Fine.
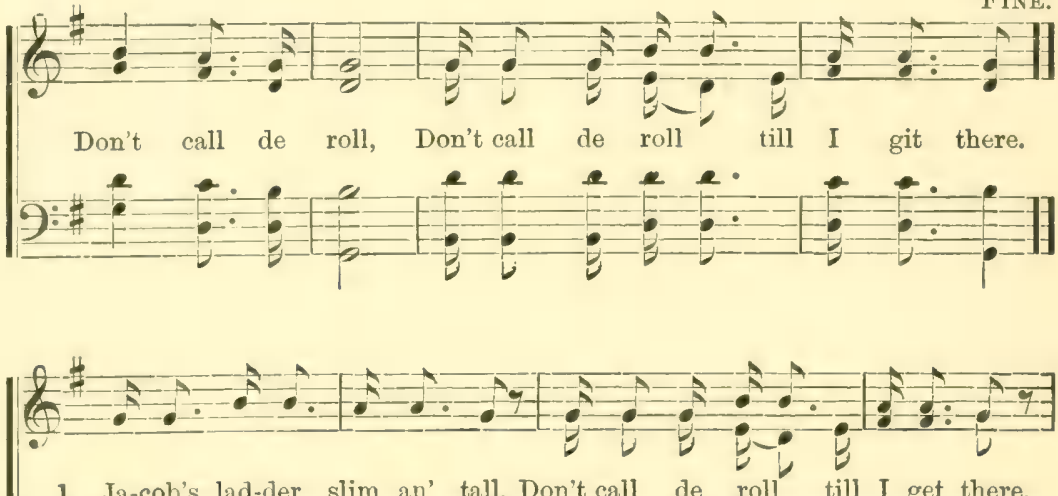

1. Ja-cob's lad-der slim an' tall, Don't call de roll till I get there,

2. Two white angels come a walking down, Don't call de roll till I get there,
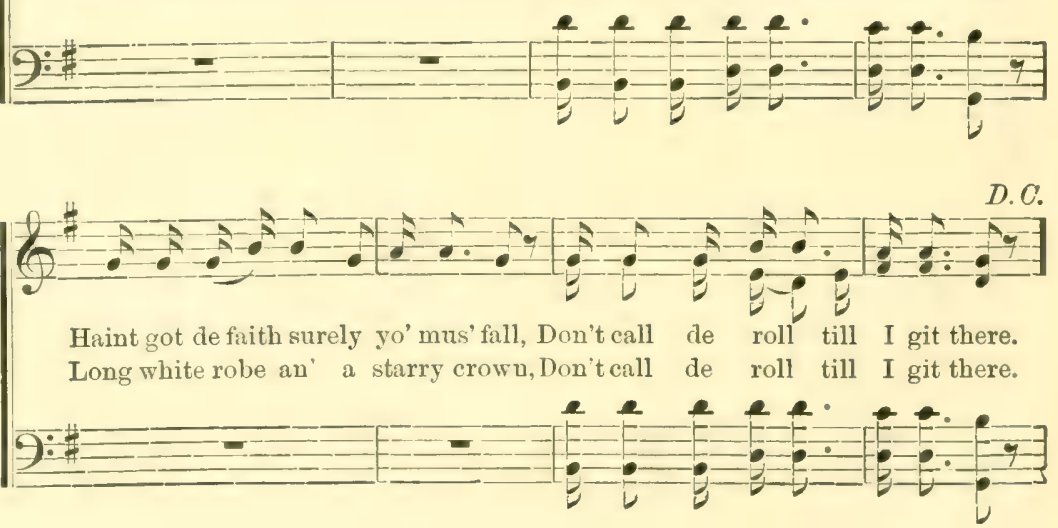


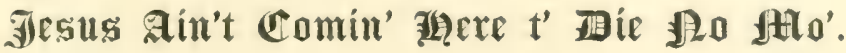
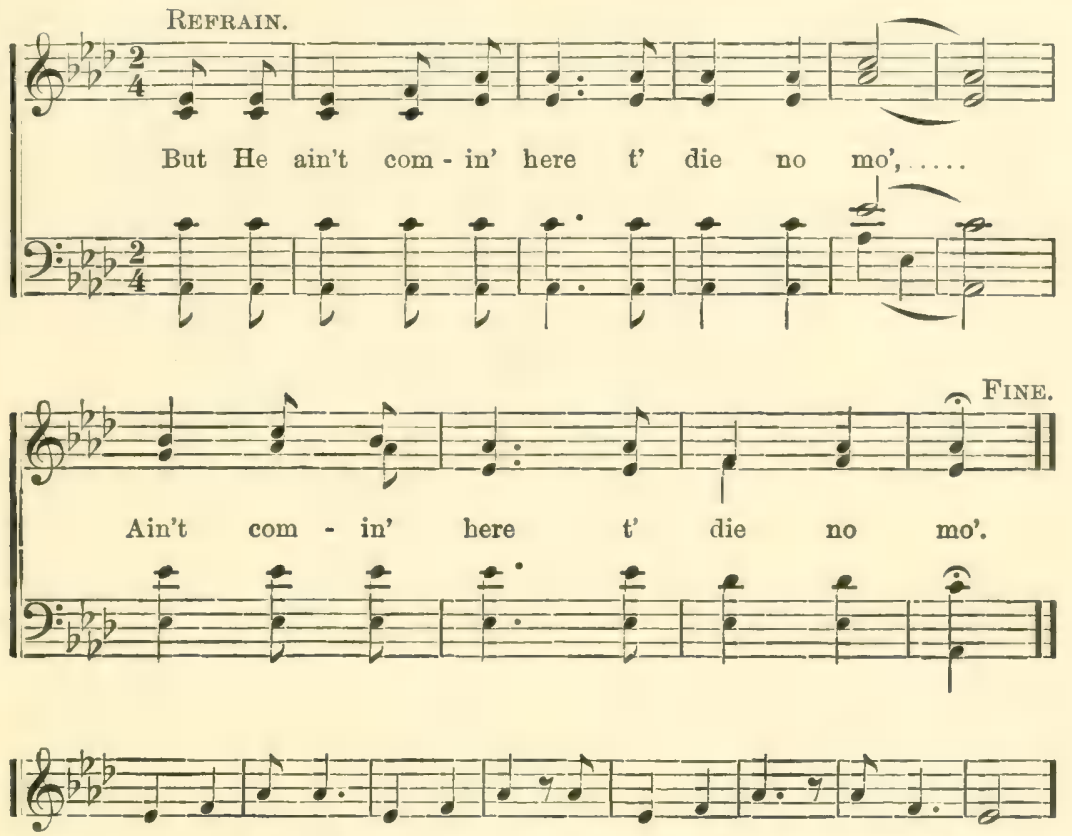

1. Vir-gin Ma-ry had one Son, The cru-el Jews had him hung.

2 Hallelujah t' de Lamb,

Jesus died for every man.

But He ain't comin' here t' die no mo',

Ain't comin' here t' die no mo'.

3 He died for yo' He died for me,

He died t' set po' sinner free.

But He ain't comin' here t' die no mo",

Ain't comin' here t' die no mo',

4 He died for de rich, He died for de po'

He ain't comin' here to' die no mo',

But He ain't comin' here t' die no mo',

Ain't comin' here t' die no mo'.

5 IIe died for de blind, He died for de lame,

He bore de pain an' all de blame.

But $\mathrm{He}$ ain't comin' here t' die no mo', Ain't comin' here t' die no mo'. 

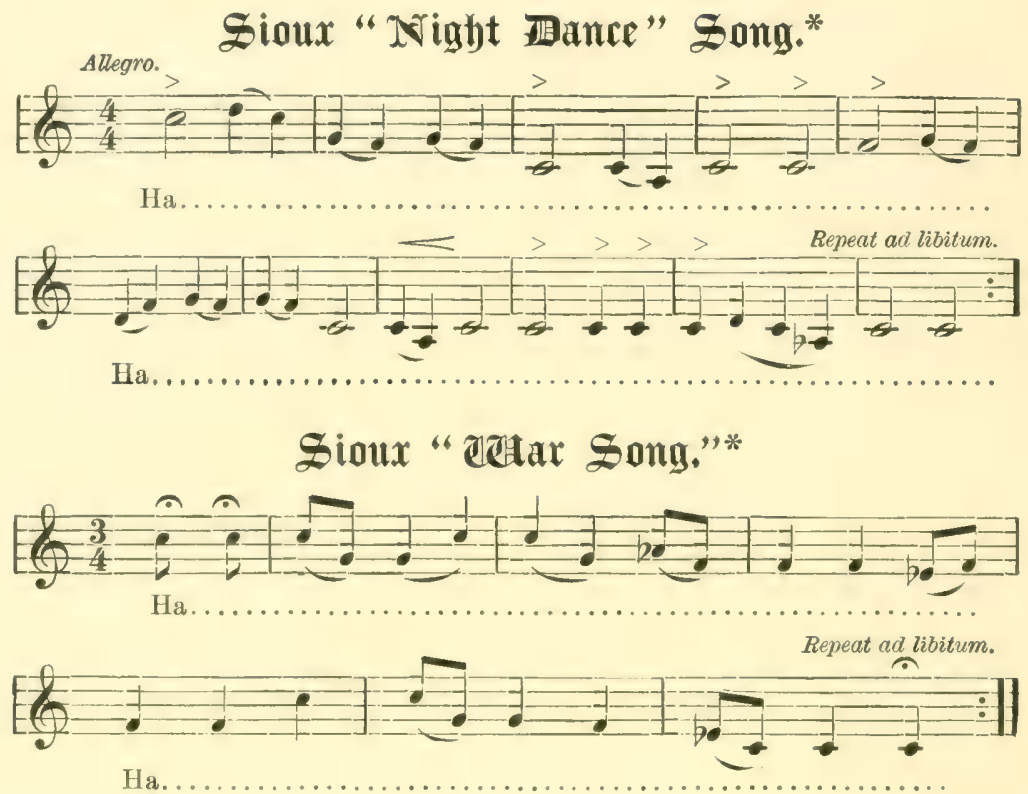

\section{Sioux "7lowe Song."}

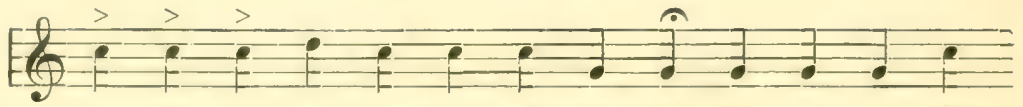

$\mathrm{Si}$ ce $\mathrm{o}$ wo tan na ma ni na si ce o wo
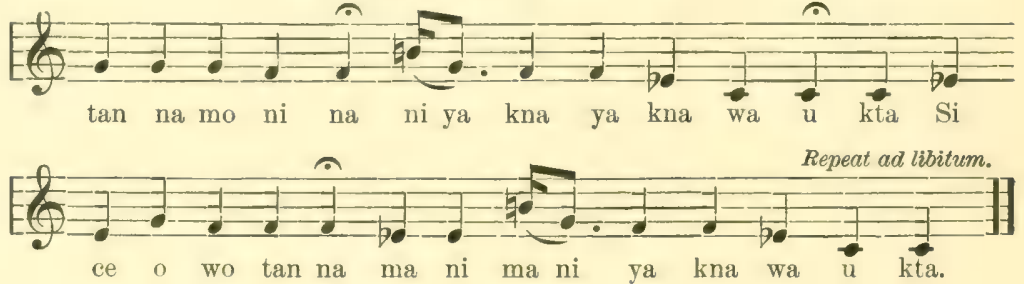

Translated-Brother-in-law, walk straight forward, I will try and follow you.

Note, - I have indicated as far as possible the actual tones of the above songs. It is impossible to put in notation the literal manner in which they are sung, as it depends entirely on the singer to change as his fancy dictates. possible.

* Sing throughout to the tone produced by saying $B a$ through the nose, and as throaty as 


\section{Tencho=setsu no etta.}

(Song for the Emperor's birthday.)

NoTE.-This song, the words of which were composed by Baron Takasaki, the poet-laureate of Japan, shows the divine honors that are paid to the Son of Heaven, as the Japanese love to call their Emperor. The feeling toward the Emperor is not so much patriotic as religious, and the song is a hymn of praise.

The glory of the sun never fails nor grows dim,

Though swift-passing clouds may ofttimes hide his light.

Now he shines through their screen, now clouds hide his rim,

Then again the winds arise and the shadows take flight.

So our nation's Sun, though hidden through ages of night,

Now rises in glory; the fresh breezes come at his call;

Clouds are fled that through centuries darkened his light.

The people now rejoice, for their Sun shines upon all.

Chorus. - Glory to our King, long live our King.

Glory to our King, long live our King.

Long may he live.

Words by Baron TAKasaki.

Moderato.
Music by Mr. S. Isawa. Harmonized by Prof. G. SAUVLET.
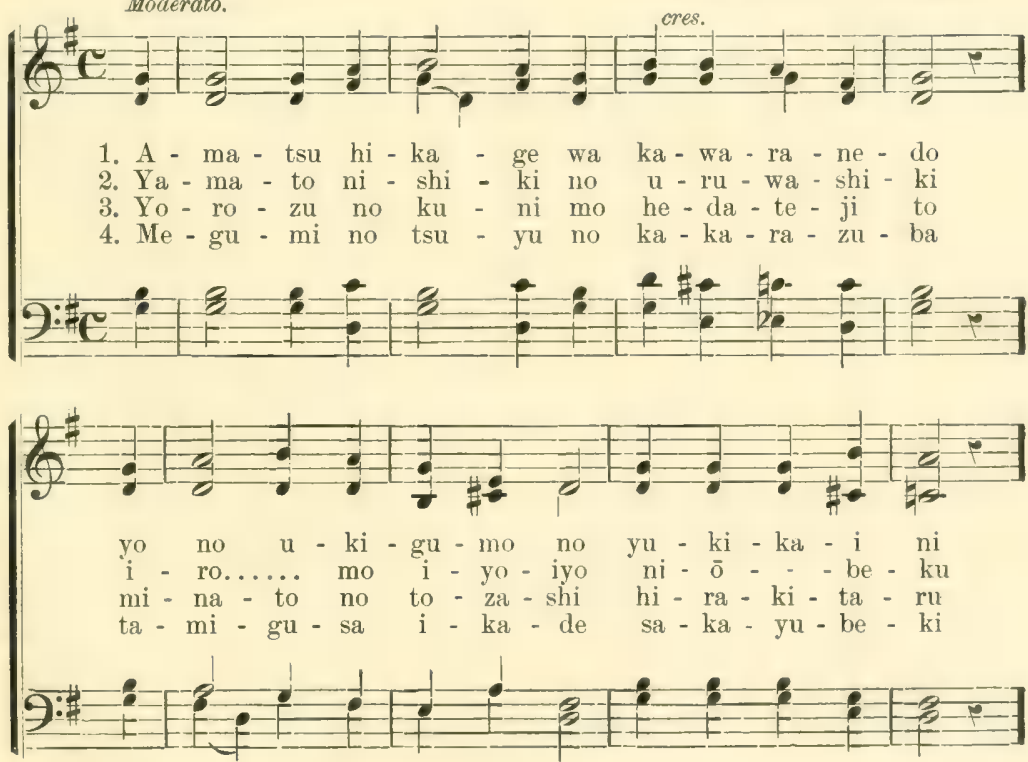


\section{Tencho=Srtsu no êta. - Continued.}
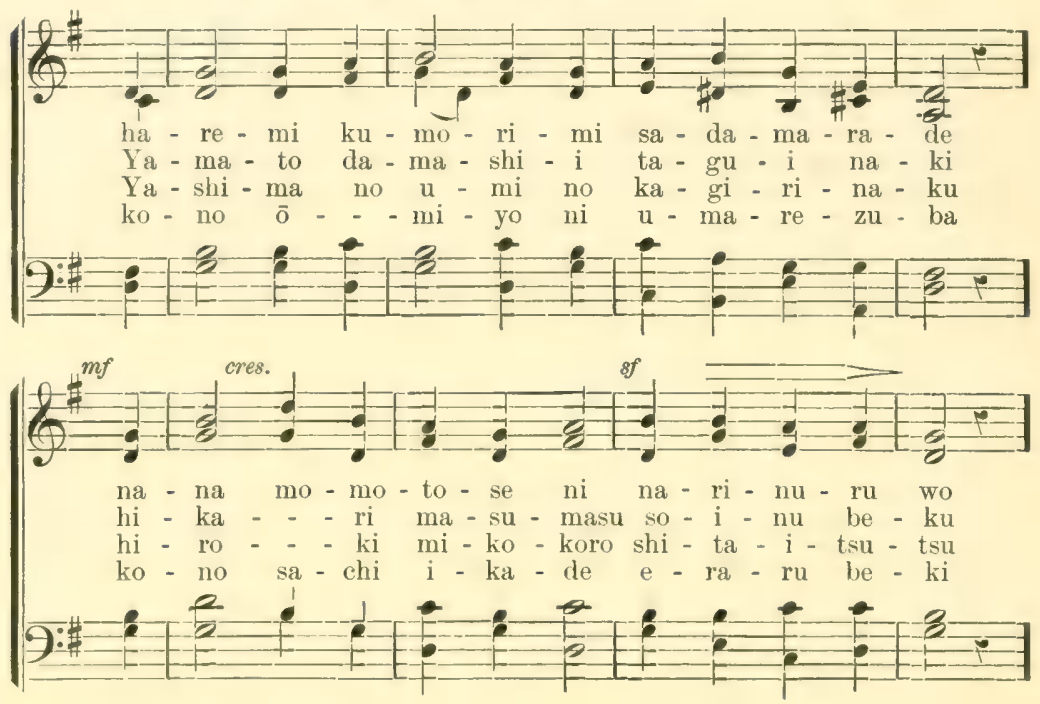

Allegretto.
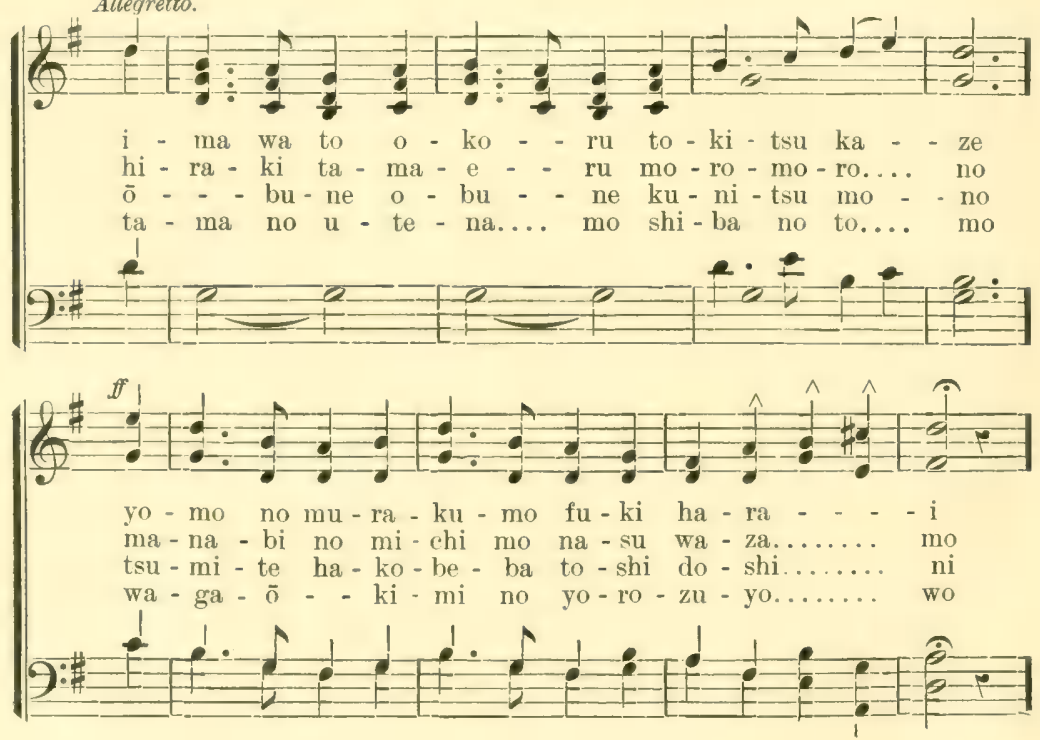


\section{Tenctyo $=$ Srtsu no efta. - Concluded.}

a tempo. $m f$
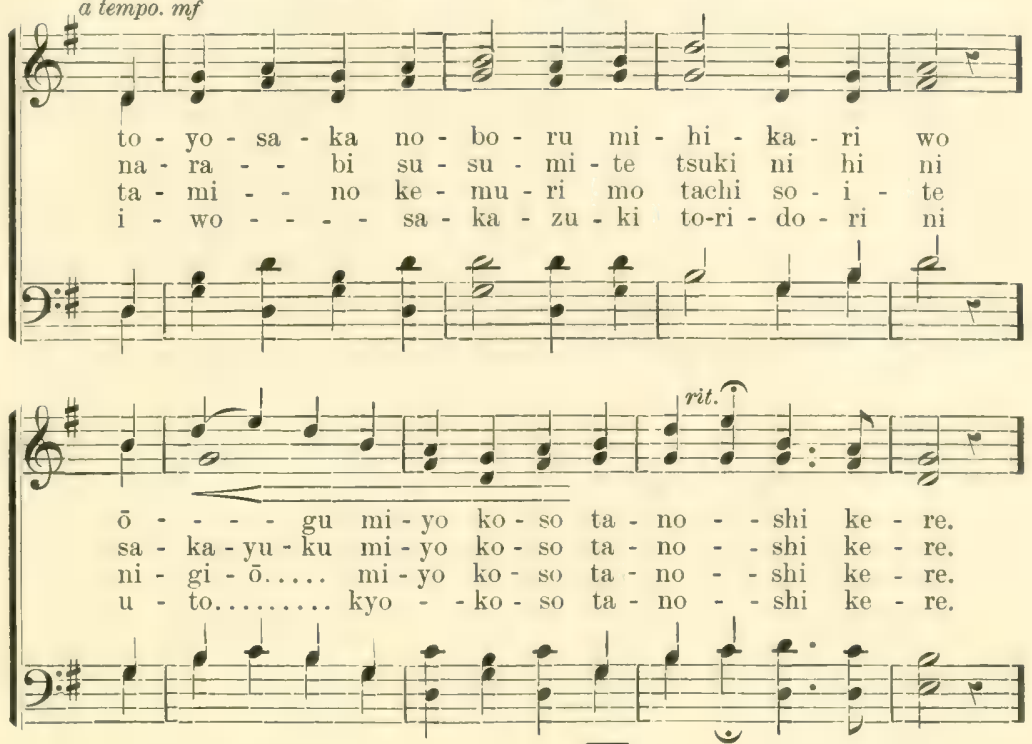

ō - - - gu mi - yo ko-so ta - no - - shi ke - re.

sa - ka - yu - ku mi - yo ko - so ta - no - - shi ke - re,

ni - gi - $\overline{0} \ldots$ mi - yo ko - so ta - no - - shi ke - re.

- to........ kyo - - ko - so ta - no - - shi ke - re.

CHORUS-Allegro.

hi-mi wa chi-yo ma-se ya-chi - yo ma-se

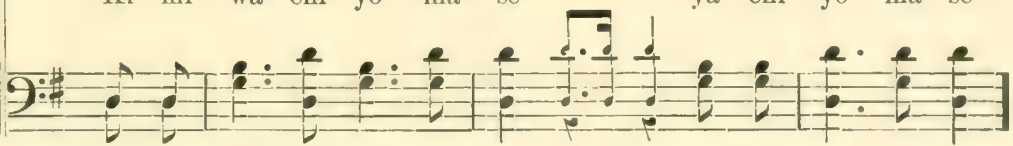

\section{2.}

Ki-mi wa chi-yo ma-serit.

Ki-mi wa chi-yo ma-serit.

Ki-mi wa chi-yo ma-se ya-chi - yo ma-se.

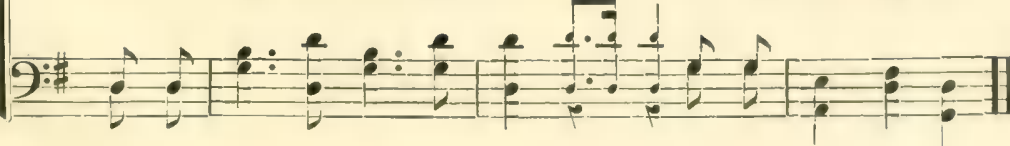




\section{Igamaii JMonoi.}

Words by King KATAKADA.

Composed by H. Berger.

(5) Helu 1. Ha-wa - ii po - no-i Na-na-i kou Mo-i Ka la ni

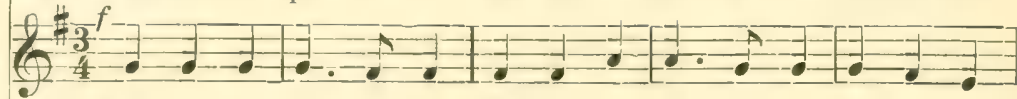
Helu 2. Ha-wa-ii po-no-i Na-na-i na' li - i Na pu a UTENOR. $f$

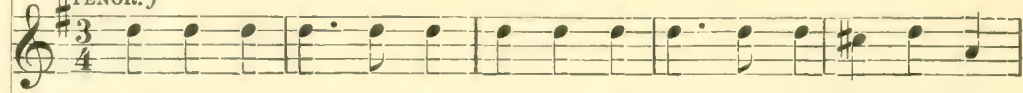
Helu 3. Ha-wa-ii po-no-i E ka la-hui... e O kau ha $9: \frac{f}{3}+2$

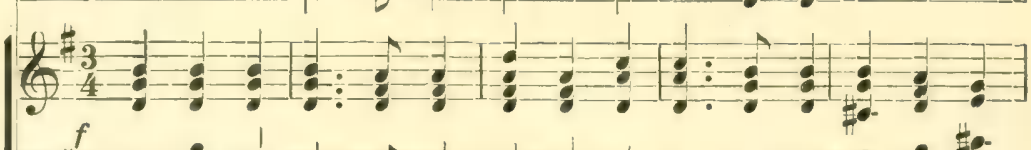

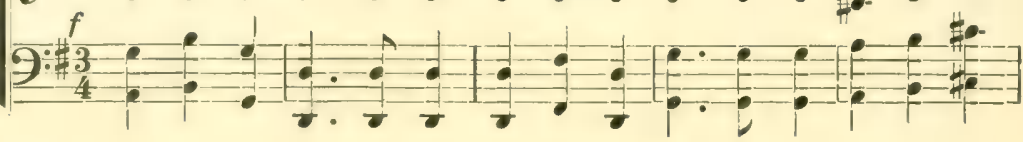
$(9)=0$ A - lii KeA-li-i, Ma ku a la ni e Ka me ha$(92)$ muli kou Na po-ki-i Ia ku a la ni e Ka me ha (9) na nui E $u-i$ Ma ku a la ni e Ka me ha $9 \div$ -

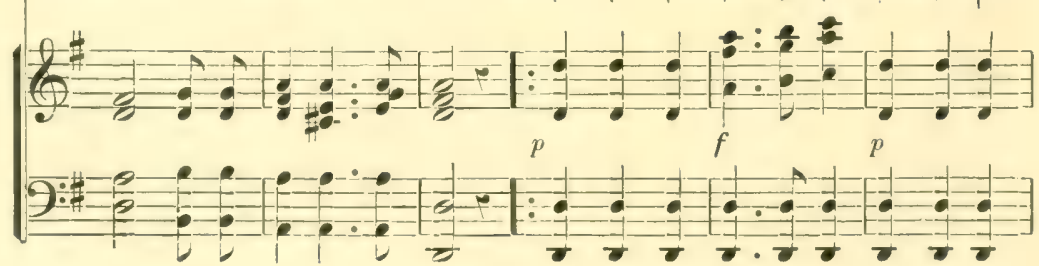




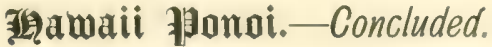

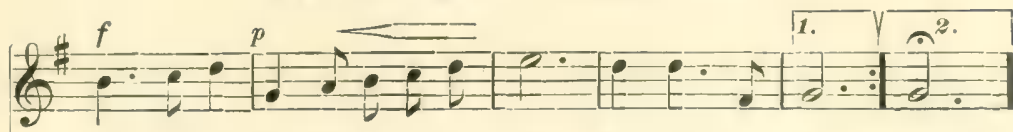

me ha e Na ka ua e pa - le Me ka i - he. he.

(e)

me ha e Na ka ua e pa-le Me ka i - he. he.

(6)

me ha e Na ka ua e pa-le Me ka i - he. he.

$9: \frac{f}{1}$

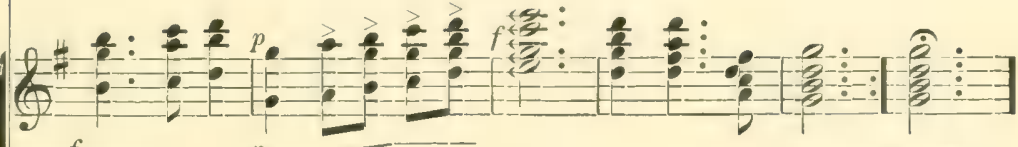

$f$

Aloya $\oplus \mathbf{P r}$

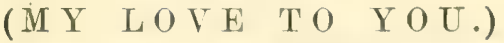

SONG AND CHORUS.

Composed by LILTOKALANI,

Princess Regent of Honolulu, Oahu, H. I.

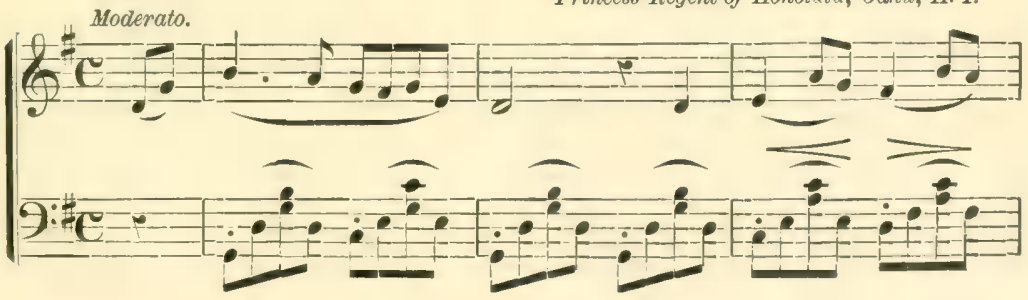




\section{Aloba Or.-Continued.}
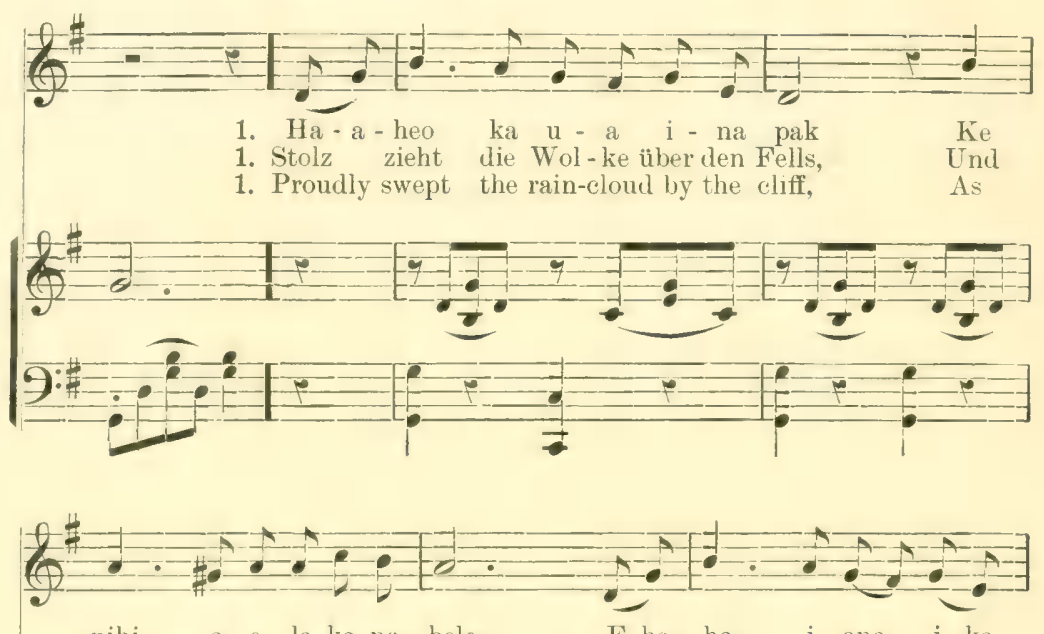

nihi a-e-la ka na-hele E ha-ha-i ana i ka als sie durch die Baüme schwebt Folgt mit Trau - er ihr die

on it glid-ed by the trees, Still fol - low-ing with grief the
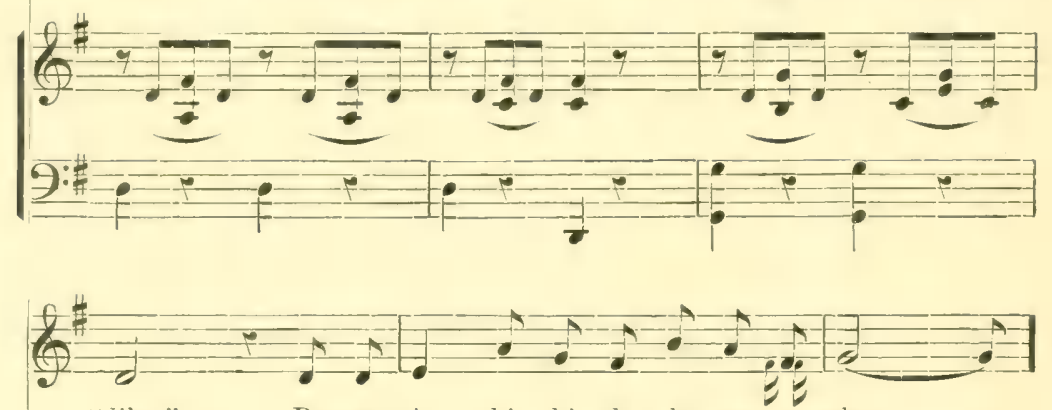

"liko," $\quad \mathrm{Pu}-\mathrm{a}$ A - hi - hi le - hu - a o uka.........

"liko," Die A - hi - hi le - hu - a des Thals..........

"liko." The A - hi - hi le - hu - a of the vale.......

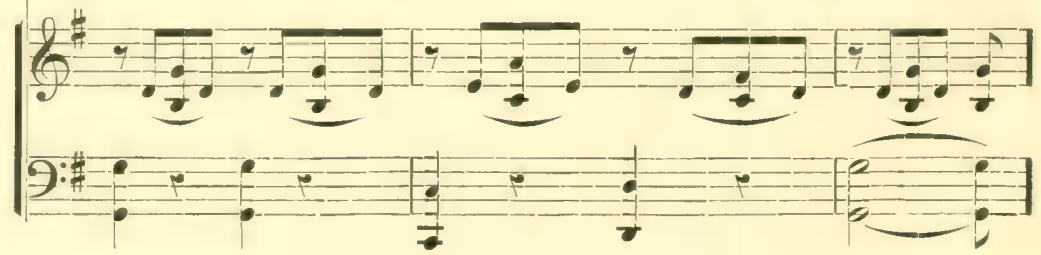


Aloba Or. - Continued.

$(2$

1. A - lo - ha o - e, a - lo - ha o - e, E lie

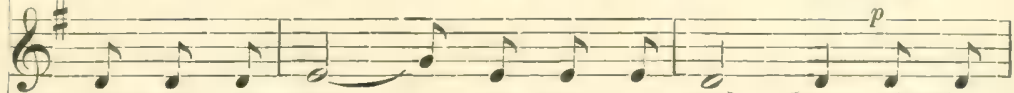

1. Nun le - be wohl,..... du Viel - ge - lieb - te, Du...

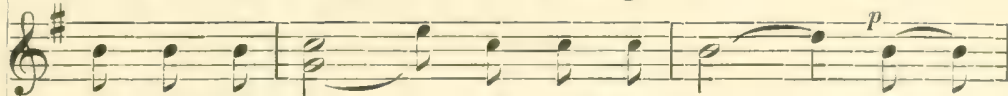

1. Farewell to thee,..... farewell to thee,..... Thou

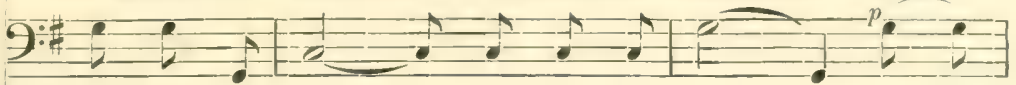

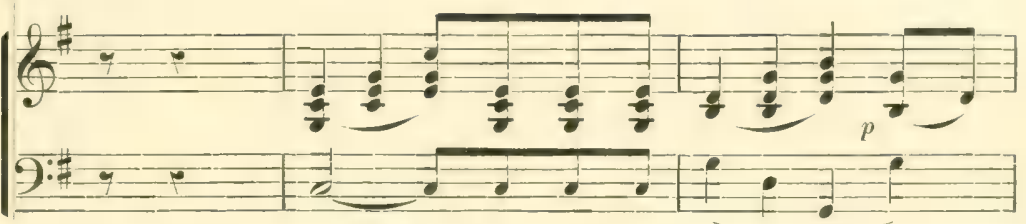

(9)
o-na-o-na no-ho i-ka li - - po
A fond em-brace a

6

Zau-be-rin in schatt'gen Lauben woh - nend, Um - ar - me mich, ich

(6)

charming one who dwells among the bow - ers, One fond em-brace be -

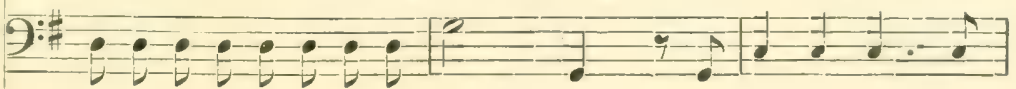

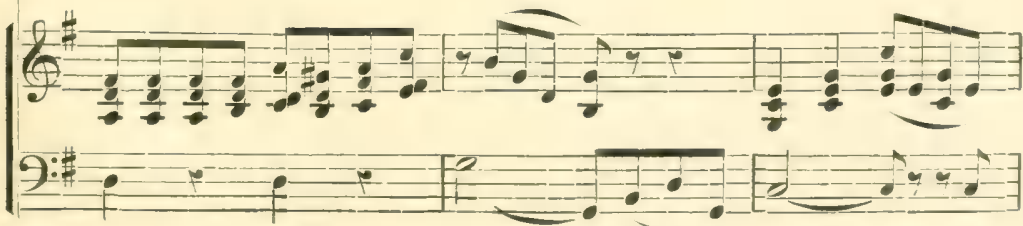




\section{Aloba (De.-Concluded.}

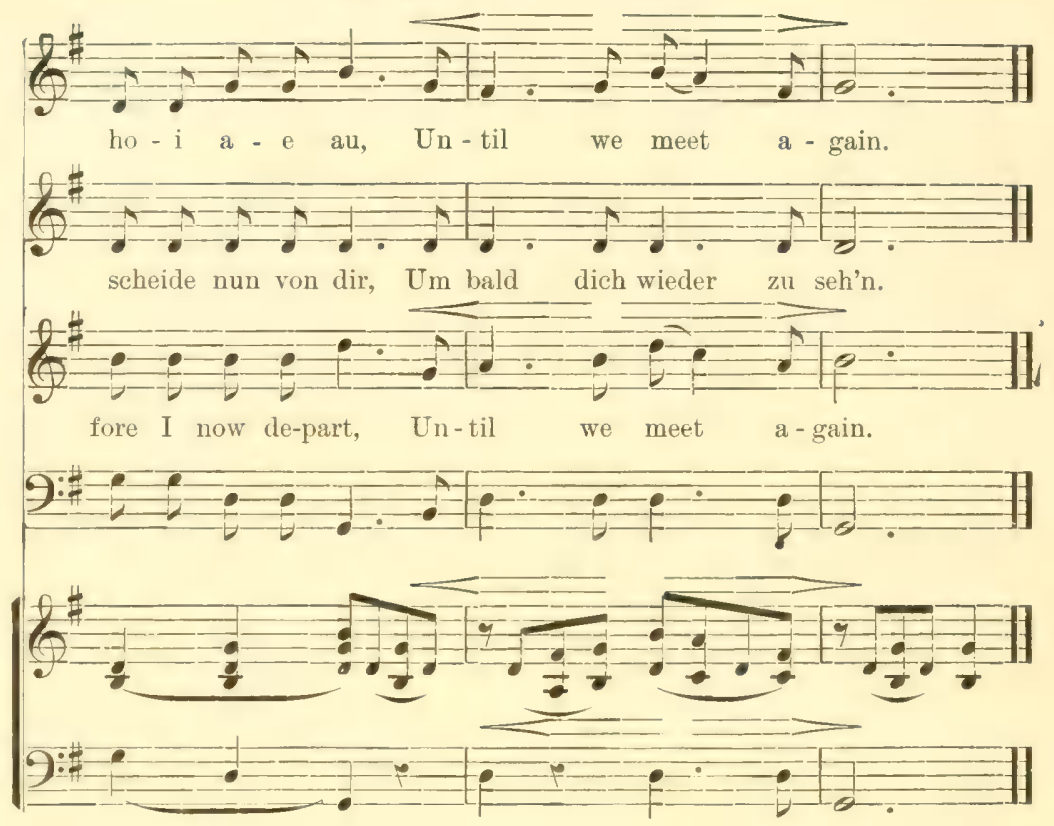

20 ka ha 'lo-ha i niki mai,

Ke hone ae nei ku'u nanaiva.

$O$ oe no ka i paloha

A lo ko e hana nei.

Chorus. Aloha oe, etc.
3 Mao popo ku'u ike i ka nani, Na pua rose o Maunavili,

Ilaila niaai namanu

Miki ala i ka nani o ka liko.

Chorus. Aloha oe, etc.
2 Dein Andenken kommt zurück zu mir, Bringt dein Bild vor meine Seele,

Ja, Geliebte, ja; Du bist mein,

Fur dich mein treues Herz soll stets schlagen.

Chorus. Nun lebe wohl, etc.
3 Deine Anmuth hat bezaubert mich, Süsse Ros' von Maunaville,

Hier wohnen die Vögel der Liebe, Und trinken Honig von schönen Lippen.

Chorus. Nun lebe wohl, etc.
2 Thus sweet memories come back to me Bring fresh remembrance of the past ;

Dearest, dearest, thou art mine,

From thee true love shall ne'er depart.

Chorus. Farewell to thee, ete.
3 I have seen and watehed thy loveliness,

Thou sweet Rose Maunaivili, And 'tis there the birds of love do dwell,

To kiss the honey from their lips. Chorus. Farewell to thee, etc. 


\title{
Cryinese Song.
}

\author{
"THE LILY SONG."
}

Furnished and translated by Loo KrE CHUNe, a Sludent at Hampton.

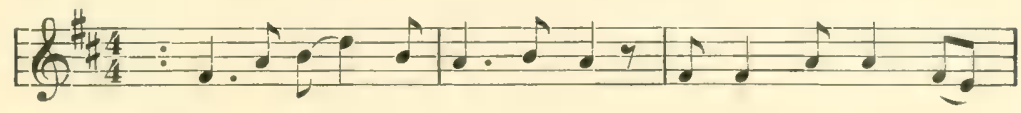

$\{$ How pret - ty lil - y flowers ! How pret-ty lil - y

When the new ones come,.... Then are the old ones

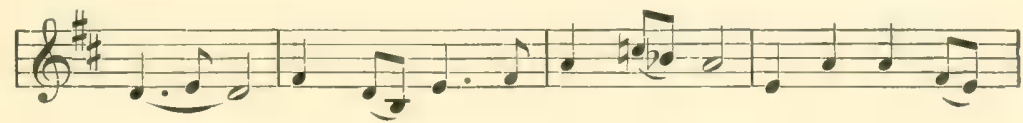

flowers! Beau - ty and sweet coun - te-nance, Have the lil - y

gone,... Down fall the pet-als soft - ly In the middle of the

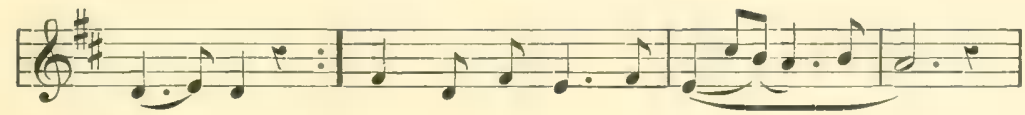

flowers ! ?

pond..... $\}$

The hap-py peo-ple sing,..........

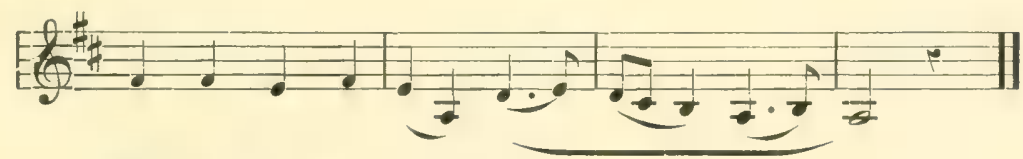

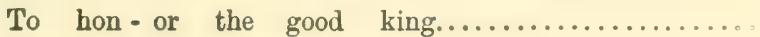




\section{İgàán (or Tgađan).}

Note. - Hadin or hadan (the call to prayer), sung by the Mueddins from the towers or minarets of the mosques, which means "God is most great," (repeated four times); "I testify that there is not a deity but God," (twice); "I testify that Mohammed is God's Apostle," (twice); "Come to prayer," (twice); "Come to security, (twice); "God is most great," (twice); "There is no deity but God."

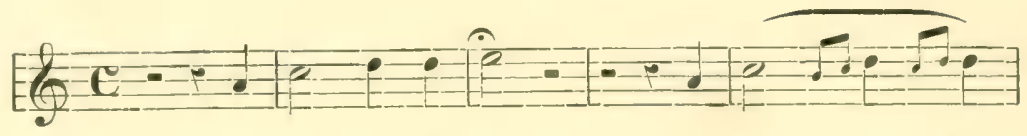

$$
\text { Al- lá hu-ak-bar, Al-lá hu - ak- }
$$
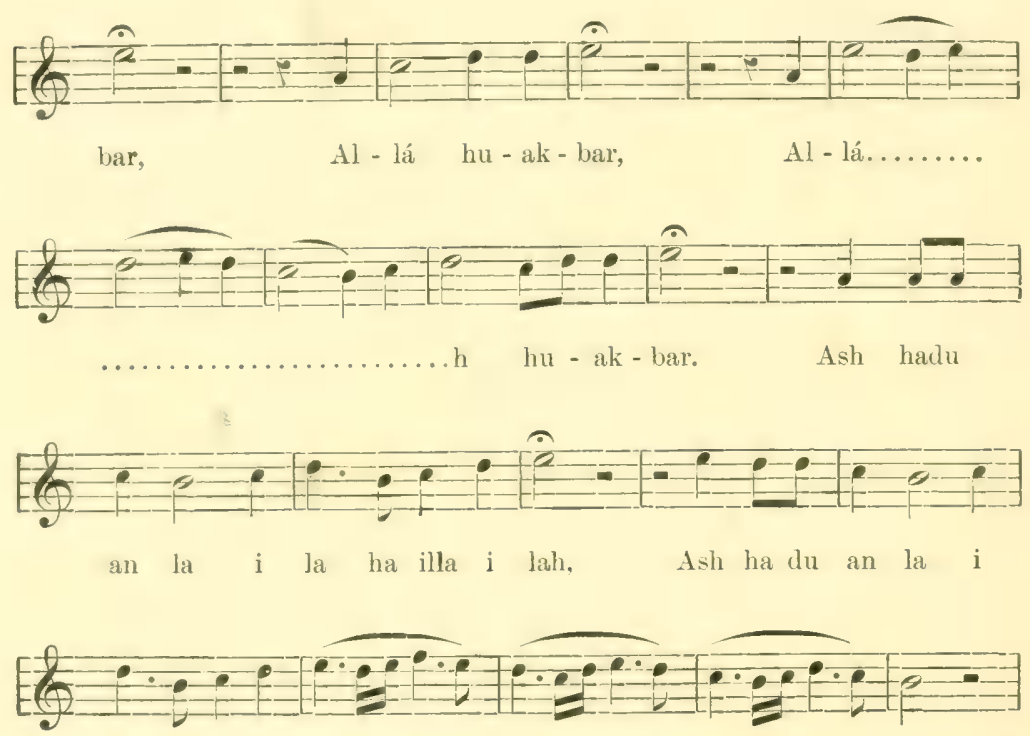

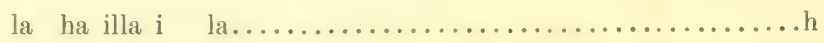

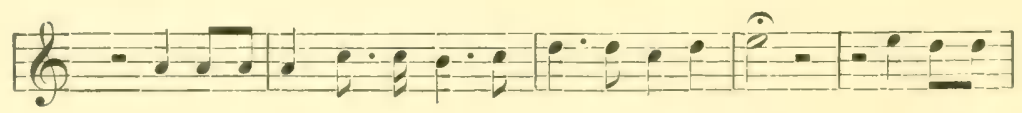

Ash ha du an-na Mo-ham-ma dar ra soolu-i-lah, Ash ha du 


\section{Ggàán (or Mąaran).-Concluded.}

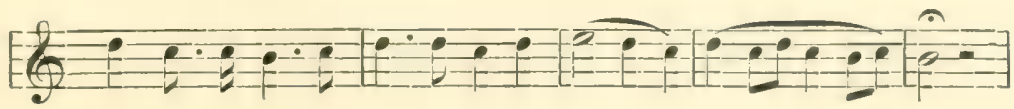

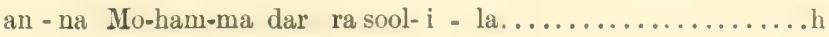

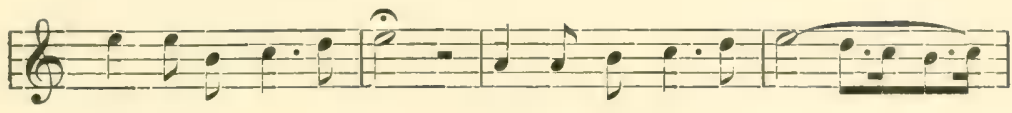

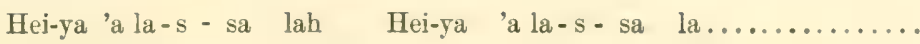

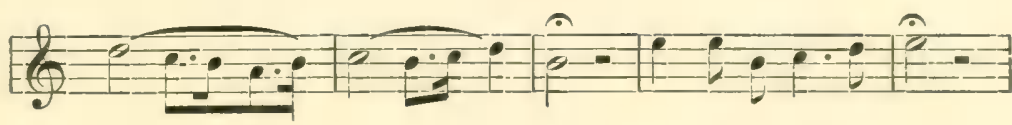

h Heiya a - la-1 - fe - lab,

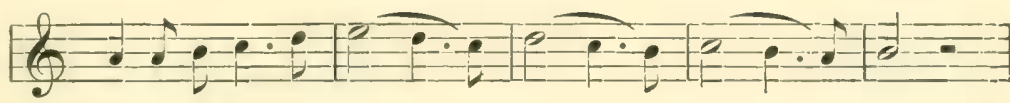

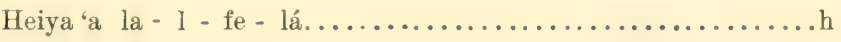

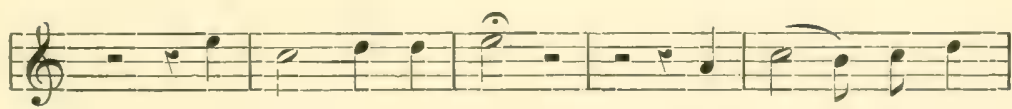
Al - la hu - ak - bar,
Al - la... hu - ak.

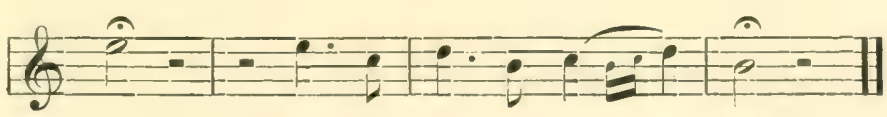

bar, la - i - la - ha i - 1 - lal - lah. 



\section{INDEX.}

A great Camp-meetin" in de Promised

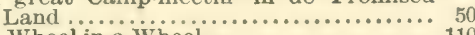

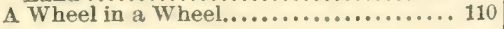

Babylon's fallin'................... 76 Bright Sparkles in de Churchyard...... 28

Come down, Sinner.

De Church ob God.

De ole Ark a-moverin $\ldots . \ldots \ldots \ldots \ldots \ldots \ldots$.

De ole Sheep done know de Road........ 26

Dere's a little Wheel a-turnin'.......... 100

De Winter'll soon be ober............. 72

Did you hear how dey Crucified my Lord? 141

Did you hear my Jesus ?............. 58

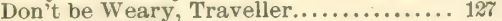

Don't call de Roll..................... 150

Don't leave me, Lord.................... 117

Don't ye view dat Ship a-come a-sailin'?. 54

Dust an ${ }^{\prime}$ Ashes.................... 79

Ef ye want to see Jesus.............. 12

Fighting on..................... 93

General Roll Call

Gideon's Band, or de milk-white Horses.

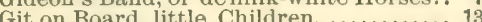

* Glory and Honor.................... 8

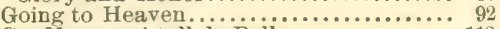

Go, Mary, an' toll de Bell ................ 113

Good Lord, shall I ever be de One ?...... 123

Good News, de Chariot's comin'........ 52

Grace before Meat at Hampton.......... 143

Gwine to live humble to de Lord.......... 135

Gwine up........................ 44

Hail! Hail ! Hail!

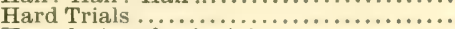

Hear de Angels singin'

Hear de Lambs a-cryin"

He is King of Kings.

He raise a poor Lazarus................ 116

* He's the Lord of Lords.................. 96

I don't feel no-ways tired............. 56

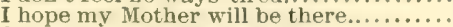

I know I would like to read............. 14

I'll be there in the Morning.............. 104

* I'm a-rolling through an unfriendly World...

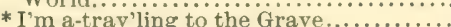

I'm goin' to join in this Alrmy..

In bright Mansions above............... 124

In dat great gittin'-up Mornin'...............
PAGE

In the Kingdom....................... 108

've been a-list'nin' all de Night long..... 75

I've been toilin' at de Hill .............. 142

I've got a Mother in de Heaven............ 137

Jacob's Ladder......................... 118 Jesus ain't comin' here t' die no mo'..... 151 John saw....................... 24 Judgment-Day is a-rollin' around....... 34

Keep me from sinkin' down .......... 73

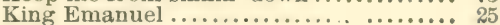

Let de Heaven Light shine on me........ 132

Let us Praise Him.................... 121 Little David, play on your Harp............ 139

Love an' serve de Lord................. 6

* Many Thousands gone............... 95

Massa owine to sell us To-morrow...... 86

Most done trabelin .................... 43

My Bretheren, don't get weary.......... 8

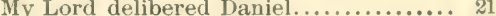

My Lord's a-riding all the Time.......... 98

My Lord, what a Mornin'............... 4 My Soul wants Something that s new..... 147 * Iy Way's cloudy.................... 97

Nobody knows de Trouble I've seen..... 9

Oh, de Hebben is shinin' $1 . \ldots \ldots \ldots \ldots \ldots .47$ Oh, den my little Soul's gwine to shine ! 1

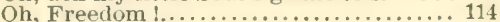

Oh, give way, Jordan $1 \ldots \ldots \ldots \ldots \ldots \ldots \ldots \ldots . \ldots \ldots$

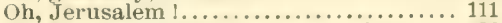

Oh, Sinner, you'd better get ready $1 . . . \ldots 36$

Oh, wasn't dat a wide Riber ?.......... 22

Oh, when I git t' Heaven $. \ldots \ldots \ldots \ldots \ldots \ldots . . \ldots 140$

Oh, yes..$\ldots \ldots \ldots \ldots \ldots \ldots \ldots \ldots \ldots \ldots \ldots 14$

Oh, yes, yonder comes my Lord 1........ 112

Ole Ship of Zion................... 85

Peter, go ring dem Bells............... 2

Peter on the Sea................... 88

Pilgrim's Song..................... 126

Prayer is de Key of Heaven........... 146

Put John on de Island................ 122

Raslin" Jacob...................... 131

Religion is a Fortune................. 17

Ride on............................ 120

Rise an' shine...................... 40

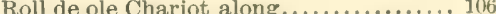

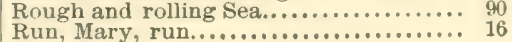

* Fisk Jubilee Collection, by permission. 
PAGE
PAGE

See fo' an' twenty Elders.............. 105 When I come to die.................. 144

Seek and ye shall find.................... 101 Who'll jine de Union $? \ldots \ldots \ldots \ldots \ldots \ldots \ldots .48$

Some $0^{\prime}$ dese Mornin's............................ 18 Wonder where is good ole Daniel........

Sometimes I feel like a motherless Child. 115

Stars in the Elements are falling........ 84

Stay in the Field..................... 10:

Sun don't set in de Mornin'............... 130

Sweet Canaan....................... 62

Sweet Turtle Dove, or Jerusalem Mornin' 68

Swing low, Chariot..................... 125

Swing low, sweet Chariot..............

Zion, weep a-low

Tell Jesus........................... 129

The Danville Chariot.................... 11

The downward Road is crowded.......... 119

The enlisted Soldiers................... 145

There were ten Virgins................. 90

View de Land....................... 10

Love Song, Sioux.................. 152

Night Dance,

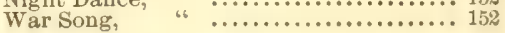

JAPANESE.

Tenchö-Setsu no Uta................ 153

HAWAIIAN.

Aloha oe......................... 157

Hawaii Ponoi.......................... 156

Walking in the Light................ 10:

Walk you in de Light. ................. 66

We are building on a Rock................ 126

What yo' gwine t' do when de Lamp

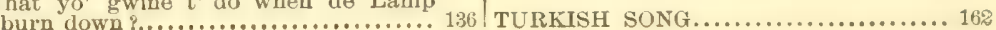

\section{CHINESE.}

The Lily Song..................... 161 




$\sqrt{75}$ 
